$$
\begin{aligned}
& \text { MEIO AMBIENTE } \\
& \text { SUSTENTABILIDADE } \\
& \text { \& } T \text { T N }
\end{aligned}
$$

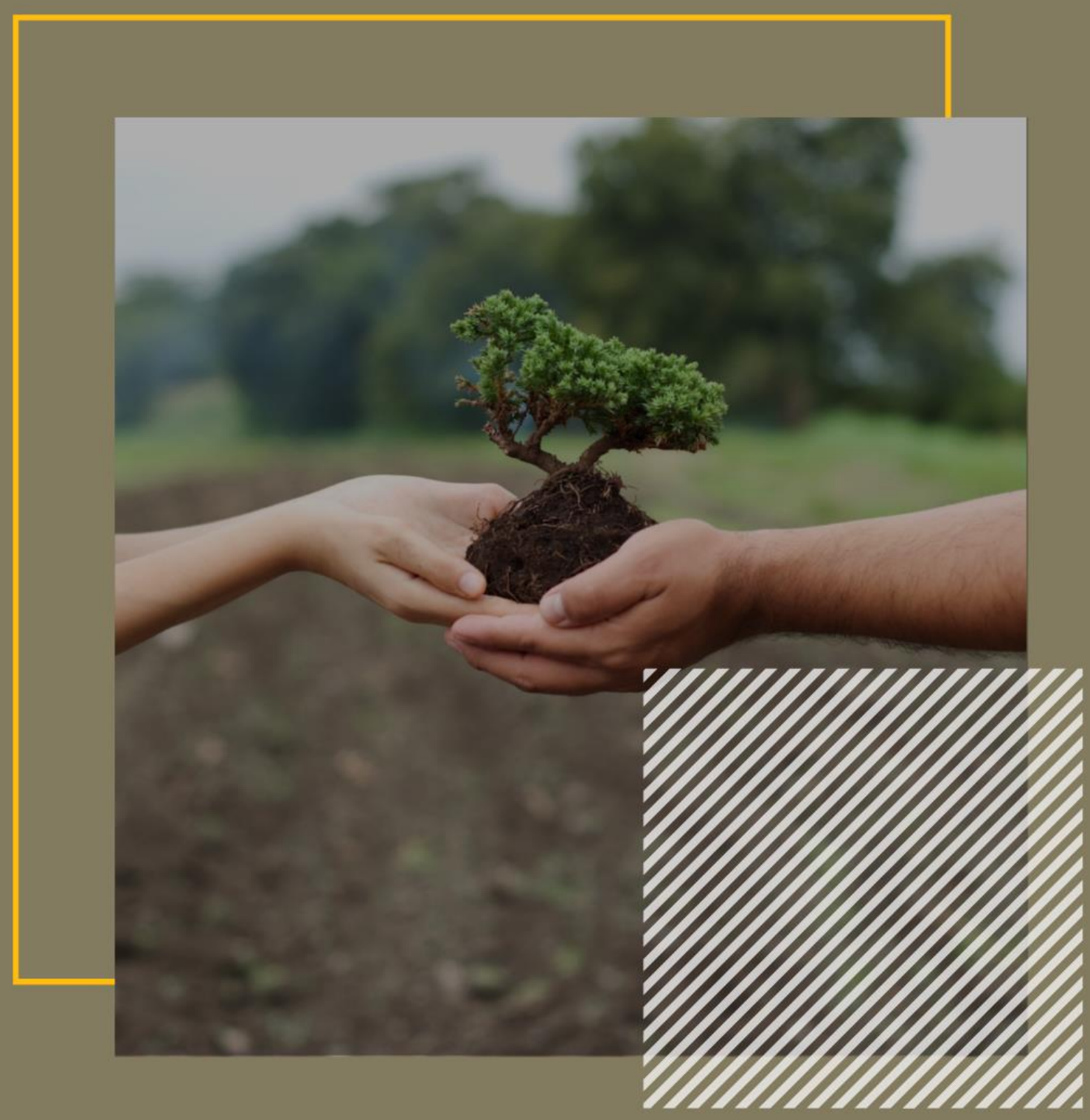

(Organizador)

José Henrique Porto Silveira

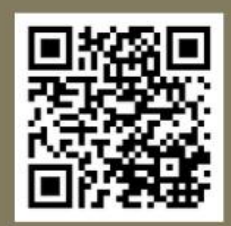

Editora Poisson

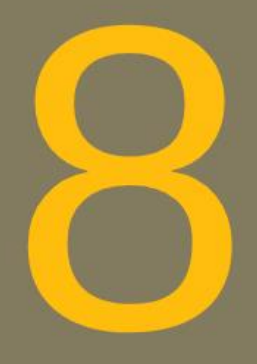




\author{
Organizador \\ José Henrique Porto Silveira
}

\title{
Meio Ambiente, Sustentabilidade e Tecnologia Volume 8
}

\author{
1a Edição
}

Belo Horizonte

Poisson

2021 
Editor Chefe: Dr. Darly Fernando Andrade

\section{Conselho Editorial}

Dr. Antônio Artur de Souza - Universidade Federal de Minas Gerais

Ms. Davilson Eduardo Andrade

Dra. Elizângela de Jesus Oliveira - Universidade Federal do Amazonas

Msc. Fabiane dos Santos

Dr. José Eduardo Ferreira Lopes - Universidade Federal de Uberlândia

Dr. Otaviano Francisco Neves - Pontifícia Universidade Católica de Minas Gerais

Dr. Luiz Cláudio de Lima - Universidade FUMEC

Dr. Nelson Ferreira Filho - Faculdades Kennedy

Ms. Valdiney Alves de Oliveira - Universidade Federal de Uberlândia

Dados Internacionais de Catalogação na Publicação (CIP)
\begin{tabular}{l} 
M514 \\
Meio Ambiente, sustentabilidade e tecnologia \\
- Volume 8 / Organização: José Henrique \\
Porto Silveira - Belo Horizonte - MG: \\
Poisson, 2021 \\
Formato: PDF \\
ISBN: 978-65-5866-123-8 \\
DOI: 10.36229/978-65-5866-123-8 \\
Modo de acesso: World Wide Web \\
Inclui bibliografia \\
1. Meio ambiente 2. Gestão. 3. Tecnologia \\
I. SILVEIRA, José Henrique Porto \\
\hline Sônia Márcia Soares de Moura - CRB 6/1896 \\
\hline
\end{tabular}

O conteúdo deste livro está licenciado sob a Licença de Atribuição Creative Commons 4.0.

Com ela é permitido compartilhar o livro, devendo ser dado o devido crédito, não podendo ser utilizado para fins comerciais e nem ser alterada.

O conteúdo dos artigos e seus dados em sua forma, correção e confiabilidade são de responsabilidade exclusiva dos seus respectivos autores.

$\underline{\text { www.poisson.com.br }}$

contato@poisson.com.br 


\section{Prefácio}

A trajetória dos seres humanos vem sendo escrita com ênfase sempre na nossa infinita capacidade de subjugar a natureza, extrair dela o que nos interessa e descartar o que não nos serve na forma de resíduos. Tais resíduos no ar, na água ou no solo representam o que deve ser evitado, mitigado ou controlado. É poluição ou degradação. Em grande parte essa trajetória desastrada é decorrente da evolução das ciências e suas tecnologias.

Mas quando se começa perceber o desastre, mesmo que lenta e gradativamente a ciências e suas tecnologias podem se constituir em reversão da catástrofe prenunciada. Novos tempos, tempos de pensar de forma sistêmica e ecológica.

Nessa perspectiva, meio ambiente e sustentabilidade são expressões fundamentais. Conceitos distintos, mas indissociáveis para podermos pensar para agir e agir para construir o futuro da humanidade. É assim que as ciências atuam, buscando respostas com a ampliação dos conhecimentos e encontrando soluções com novas tecnologias. Nesta busca incessante para criar e construir soluções para os problemas ambientais e de encontrar caminhos para manifestação dos preceitos da sustentabilidade, tecnologias são ensaiadas e sugeridas como viáveis e mesmo projetadas para execução.

E este é o verdadeiro papel das ciências nas academias e nos centros de pesquisa, envolvendo as muitas disciplinas que se integram na construção do conhecimento socioambiental: engenharia, arquitetura, sociologia, psicologia, geografia, antropologia, biologia, pedagogia e tantas outras. Quase sempre são processos que envolvem a multi, a inter e a transdisciplinaridade.

Nessa coletânea, a intenção principal é mostrar possibilidades, algumas mais outras menos detalhadas, mas todas dotadas de intencionalidades em relação à busca de um futuro melhor.

Como ambientalista e profissional com muitos anos de atuação nas áreas de avaliação de impactos e educação ambiental vejo como muito promissor as ideias e soluções técnicas que estão sendo gestadas no meio acadêmico nas áreas de meio ambiente e sustentabilidade.

Reitero que as temáticas como meio ambiente e sustentabilidade devem estar em constante interação na construção do futuro, já que inevitavelmente a nossa permanência como espécie depende da permanência de outras espécies da flora e da fauna e da boa qualidade dos elementos ar, água e solo. Nunca é tarde na busca de reverter a nossa trajetória, usando bom senso e o conhecimento proporcionado pelas ciências e pelas culturas milenares sobre o meio ambiente. 


\section{Sumário}

Capítulo 1: Análise bibliométrica das produções sobre uso e ocupação de 1978 a 2017 do Simpósio Brasileiro de Sensoriamento Remoto.

Jô Vinícius Barrozo Chaves, Lia Toledo Moreira Mota, Regina Márcia Longo

DOI: 10.36229/978-65-5866-123-8.CAP.01

Capítulo 2: Grandes Projetos Urbanos e a reinvenção das cidades. A implantação de um shopping em Juiz de Fora, MG 14

Luciane Tasca

DOI: $10.36229 / 978-65-5866-123-8 . C A P .02$

Capítulo 3: A problemática de um sistema de esgotamento sanitário na Ocupação Izidora em Belo Horizonte/MG

Letícia Helen de Rezende, Marcela Soares Souza Vaz Correia, Pedro Henrique Fernandes Lage, Raquel Sampaio Jacob, Tatiane Aparecida Pereira Mendes

DOI: 10.36229/978-65-5866-123-8.CAP.03

Capítulo 4: Modelagem de rotograma para mitigação dos riscos associados ao transporte de cargas perigosas - Nitrato de Amônio pela SP 160 - Rodovia dos Imigrantes

Anna Julia Renzo Aguayo

DOI: 10.36229/978-65-5866-123-8.CAP.04

Capítulo 5: Educar para conservar: Educação Ambiental no Ensino Fundamental II com foco no bioma de Mata Atlântica 45

Luiz Fernando Ferreira, Fabiola Mangabeira Ceolato da Silva, Adriele Barrelin de Souza, Ana Caroline Vitor Avelar, Karina Mara Labanca, Raquel Elisamara da Silva Lima, Daniela Ferreira Cardoso

DOI: 10.36229/978-65-5866-123-8.CAP.05

Capítulo 6: Aspectos alimentares da palma forrageira (Opuntia ficus indica L. Mill) no Semiárido do Brasil 50

Ana Elisabeth Cavalcanti Santa Rita, Xirley Pereira Nunes, David Fernandes Lima, Márcia Bento Moreira, Carlos Henrique Brandão Gomes

DOI: 10.36229/978-65-5866-123-8.CAP.06 


\section{Sumário}

Capítulo 7: As redes técnicas ambientais - Uma visão geral das dificuldades do gerenciamento de resíduos sólidos no Pontal do Paranapanema.

Allan Elias da Silva

DOI: 10.36229/978-65-5866-123-8.CAP.07

Capítulo 8: Aplicação da dinâmica de sistemas na implementação de modelo computacional para estimação da qualidade do efluente de lagoas facultativas

Bruna Logatti, Erich Kellner

DOI: 10.36229/978-65-5866-123-8.CAP.08

Capítulo 9: Toxicidade do efluente e consumo hídrico e energético no tingimento de poliamida

Aline Viana de Morais, Camila Gomes Melo, Vanessa Silva Granadeiro Garcia, Maria da Conceição Costa Pereira, Jorge Marcos Rosa, Sueli Ivone Borrely

DOI: $10.36229 / 978-65-5866-123-8 . C A P .09$

Capítulo 10: Geoquímica orgânica do sistema estuarino tropical Sergipe-Poxim: Fontes de matéria orgânica e riscos ecológicos

Michel Rubens dos Reis Souza, Ewerton Santos, Marcelo da Rosa Alexandre

DOI: 10.36229/978-65-5866-123-8.CAP.10

Capítulo 11: Geotecnologias aplicadas ao mapeamento de áreas inundáveis frente a cenários de eventos extremos. Estudo de caso da microbacia do arroio São Lourenço, RS. 103

Fernando Petersen Cardoso, Flávia Cristiane Farina, Tamiris da Silva Alves

DOI: 10.36229/978-65-5866-123-8.CAP.11

Capítulo 12: Evapotranspiração de referência e balanço hídrico no município de Itabaiana/Sergipe

Nívia Raquel Oliveira Alencar, Eveline Leal da Silva, Michelle Pereira da Costa da Silva, Ramiro Ferreira dos Santos Farias, Inajá Francisco de Sousa

DOI: $10.36229 / 978-65-5866-123-8 . C A P .12$

Capítulo 13: Consumo de água em meios de hospedagem brasileiros 118 Jhonata Wesley Gomes Barbosa, Evany Adriane Maria Dias Batista, Diogo Henrique Fernandes da Paz DOI: $10.36229 / 978-65-5866-123-8 . C A P .13$

Autores: 


\section{Capítulo 1}

Análise bibliométrica das produções sobre uso e ocupação de 1978 a 2017 do Simpósio Brasileiro de Sensoriamento Remoto

Jô Vinícius Barrozo Chaves

Lia Toledo Moreira Mota

Regina Márcia Longo

Resumo: Com o processo de alteração do solo para incorporação de atividades agrícolas, expansão urbana e mineração, notou-se a necessidade de monitoramento destas áreas afetadas, sendo assim, a incorporação de mapeamentos elaborados a partir de sensores remotos e demais geotecnologias tornou-se extremamente efetiva, destacando a abordagem por dados espaciais em estudos sobre adversos tipos de ocupação do solo e alterações da vegetação, auxiliando no monitoramento destas áreas e diferentes abordagens em pesquisas. Desta forma, o seguinte trabalho teve como objetivo, fazer um levantamento bibliométrico que envolva os temas de cobertura vegetal e uso e ocupação do solo dos documentos publicados nos anais do "Simpósio Brasileiro de Sensoriamento Remoto" - SBSR. Para composição desse estudo, utilizou-se as palavras-chave Área Verde, Área Verde Urbana e Veículo Aéreo Não Tripulado (VANT) a fim de auxiliar na coleta e divisão dos arquivos do SBSR. Posteriormente foram produzidos gráficos dos seguintes aspectos levantados: publicação anual, instituições que publicaram, regiões abrangidas e temas abordados pelos artigos. Com os resultados produzidos, tornou-se possível a identificação do maior nicho de publicações voltado às Áreas Verdes. Identificou-se também que a maioria dos estudos estão centralizados na região sudeste, com o Instituto Nacional de Pesquisa Espacial (INPE) sendo o maior contribuinte de conteúdo e destacando-se objetivos de trabalhos voltados para análises e mapeamento de áreas verdes e fragmentos florestais.

Palavras-chave: Áreas Verdes; VANT; Cobertura Vegetal. 


\section{INTRODUÇÃO}

Atualmente o uso e ocupação do solo encontra-se sob diversos tipos de ação antrópica no meio natural, abrangendo tanto atividades agrícolas para atingir as necessidades humanas atuais, como para a expansão de território urbano. Para tanto, a mitigação dos efeitos sobre a cobertura vegetal implica na necessidade de monitoramento destas áreas, para que possibilite a interação destes problemas ao desenvolvimento de políticas públicas (MENDOZA, 2010; MENESES, 2013). No entanto, para melhor efetividade das análises a serem monitoradas, é imprescindível o uso de dados multi-temporais, onde se pode comparar e compreender de forma clara as características da região (MORTBERG, 2007; COELHO, 2013).

Para a elaboração de análises multi-temporais, é necessário, além de dados comuns, é imprescindível o uso de dados espaciais, produtos oriundos do sensoriamento remoto, principalmente, para levantamentos e pesquisas sobre áreas. Dada a importância do sensoriamento, entende-se a relevância das técnicas de geotecnologia para garantia destas formas de análises. As ferramentas de geotecnologia auxiliam na avaliação, identificação, classificação, manipulação e interpolação de dados espaciais para monitoramento e análises, destacando a importância destes mecanismos para trabalhar com áreas sob pressão de atividades antrópicas, estudo de cobertura vegetal, atividades de mineração e agropecuárias, etc (RITCHIE et al., 2003; STANGANINI e LOLLO, 2018). Com o desenvolvimento das geotecnologias, surgiram novas aplicações com o uso do sensoriamento remoto, por exemplo, a embarcação de sensores em Veículos Aéreos Não Tripulados (VANT), permitindo uma nova abordagem para o trabalho de mapeamento e monitoramento em cenários adversos de estudo (CATUREGLI et al., 2016; NETO et al., 2017).

Tendo em vista a ampliação de ambientes sob carência de estudos para medidas de correção ou para análises da situação local sob risco, entende-se que o uso de ferramentas geotecnológicas se destacou, tendo aumento significativo na sua dispersão em temas de pesquisas. Em razão desta nuance, o levantamento da tendência em que as práticas de estudos sobre ambientes alterados e como tem sido feito o construído suas metodologias, se torna importante, principalmente para evidenciar as novas tecnologias e as informações que estão em aplicação no ambiente científico e no mercado. (SILVA et al., 2016; SMALL, 2003 apud WATANUKI et al., 2014).

Sobre o assunto abordado, o seguinte trabalho teve como objetivo o levantamento bibliométrico e análise dos estudos publicados, entre os anos de 1978 e 2017, no "Simpósio Brasileiro de Sensoriamento Remoto" - SBSR, abordando temas de uso e ocupação do solo em Áreas Verdes, Áreas Verdes Urbanas e VANT.

\section{METODOLOGIA}

O seguinte estudo circundou as publicações no SBSR, o qual aborda trabalhos sobre a tecnologia de sensoriamento remoto como as ferramentas geotecnológicas ambientam-se nos temas tais quais agricultura, florestas, zona urbana, oceanografia, hidrologia, aplicações e assuntos que envolvem tecnologias da informação.

A metodologia aplicada se baseou no levantamento bibliométrico, para assim ser possível a análise de forma quantitativa dos documentos encontrados, procurando destacar o como se desenvolve a produção cientifica na área de geotecnologias (MORAES JUNIOR et al. 2013). A investigação se deu no período de 1978 a 2017, com o uso dos estudos publicados nos anais do Simpósio Brasileiro de Sensoriamento Remoto. Para separar os arquivos de uso e ocupação dos demais, utilizou-se esse tema no âmbito das palavras chaves de Áreas Verdes e Áreas Verdes Urbanas, ambas tendo como intuito a representação de cobertura vegetal no geral, seja como APP, Unidade de Conservação e demais fragmentos, sejam eles inseridos em áreas urbanas ou outras pressões.

0 processo de coleta dos artigos funcionou por enquadramento de cada palavra chave: os artigos focados na degradação e fragmentação de cobertura vegetal de áreas inseridas exclusivamente em meio urbano foram enquadrados no subtema "Área Verde Urbana"; os artigos que abordavam o uso e ocupação em um ambiente geral, sem a especificação da área urbana foram enquadrados no subtema "Área Verde". Por fim, os artigos que abordavam qualquer assunto envolvendo VANT foram integrados ao subtema "VANT". Verificou-se a necessidade de compreensão acerca do crescimento dos estudos de VANT de uma forma geral, não apenas em temáticas de Uso e Ocupação do solo, devido ao seu recente destaque no cenário de Sensoriamento Remoto e no ambiente de publicação no Simpósio estudado. Conforme coletavam-se os trabalhos, os mesmos eram alocados em pastas conforme a sua palavra-chave (pastas de nível 1), e em seguida eram separados por ano (pastas de nível 2) Exemplo: 
- $\quad$ Pasta de nível 2: Áreas verdes: 1978, 1982, ..., 2017;

- $\quad$ Áreas verdes Urbanas: 1978, 1982, ..., 2017;VANT: 2007, 2011, ..., 2017.

Após a coleta dos trabalhos e sua distribuição já estabelecida, iniciou-se o processo de montagem das tabelas para a elaboração dos gráficos. Os assuntos utilizados para essa etapa foram os níveis de publicação por anais referente a cada palavra-chave, trabalhos por palavra-chave, instituições de pesquisas, regiões abrangidas pelos estudos e temas em comuns por artigos. Os temas em comuns foram abordados pela sua frequência, sendo assim, subdividam-se em monitoramento, análise, avaliação, identificação/levantamento e mapeamento.

\section{RESULTADOS E DISCUSSÃO}

Ao término da seleção de artigos publicados nos anais do período selecionado, deparou-se com um total de 324 arquivos, em que 161 enquadraram-se no subtema Áreas Verdes (49,69\%), 104 Áreas Verdes Urbanas (32,10\%) e 59 relacionados a VANTs (18,21\%), assim como representado na Figura 1 com a distribuição em formato de Pizza. Ao analisar o Gráfico 1, ilustrando a relação das publicações por anuário publicado pelo SBSR.

Neste momento é possível observar um crescente publicações no Gráfico 1, no entanto, há alguns momentos que há uma queda, ou até então que não haja nenhum artigo selecionado. Por exemplo, em 1986, que não aponta uma publicação referentes aos assuntos abordados. Este ponto ele se encontra desta forma devido ao ano ter apenas publicações voltadas a áreas urbanas, porém, nenhuma abordagem sobre elas se refere ao uso e ocupação ou de coberturas vegetais, ou então sobre VANTs.

Figura 1 - Distribuição de artigos por subtema levantado

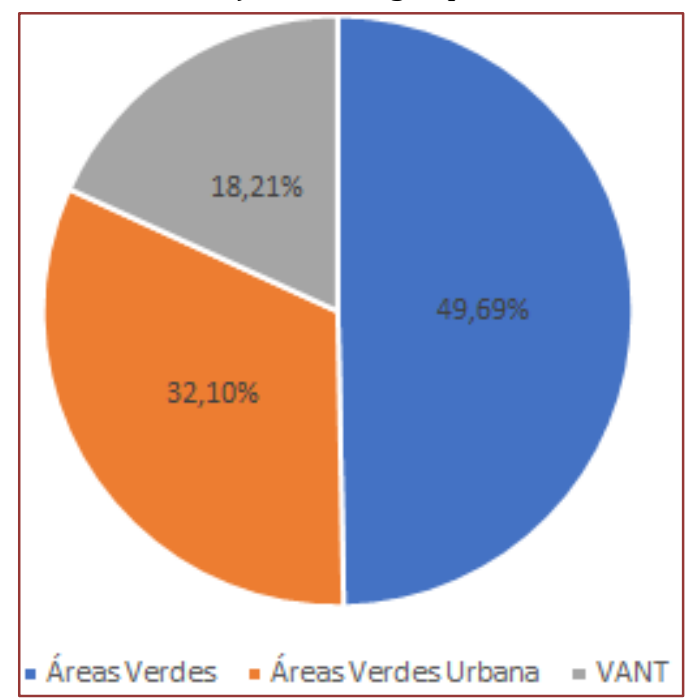

Pode-se perceber que no período de 1978 a 1998 havia sempre maior produção de conteúdo referentes a Áreas Verdes envolvidas em cenários diversos, mas pouquíssimos envolvidos em limites urbanos. Segundo Niero et al. (1982), apontam algumas dificuldades, como erros de omissão referentes à classe urbana em alguns determinados pontos do mapeamento. Enquanto, Barros e Guichou (1984) destacam problemas no uso de análises automáticas de espaços físicos de mesma textura no tecido urbano, sendo algo a ser levado em consideração na aplicação do sensoriamento remoto para essas áreas. 


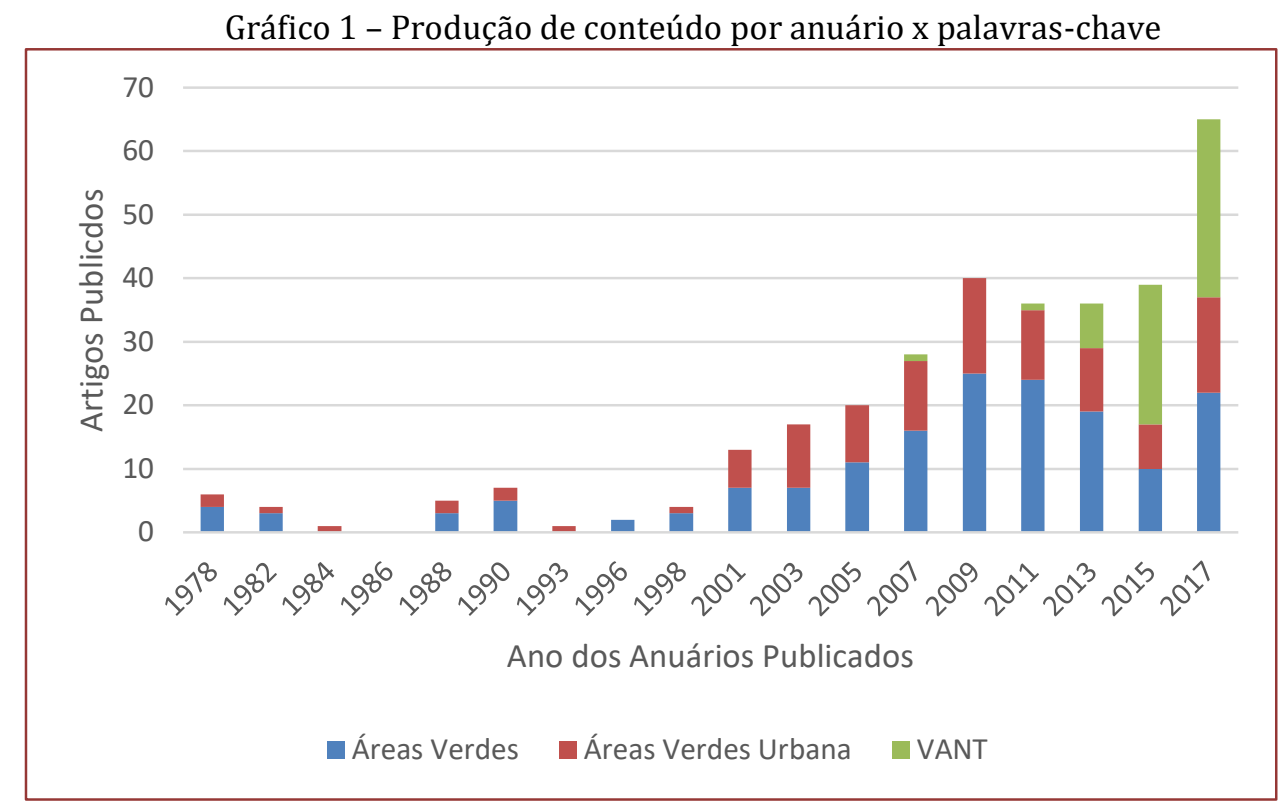

Após a identificação desses problemas relatados não houve mais nenhuma indagação, no entanto a crescente da publicação em seguida desse período. Entre os anuários de 2001 a 2017, identificou-se não apenas um grande aumento, mas um aumento de artigos com as temáticas no entorno de uso e ocupação e coberturas vegetais. Neste intervalo, identificou-se o início de temas envolvendo o uso de VANTs, com início tímido, tendo uma publicação no ano de 2007, e posteriormente em 2011 apenas, onde se tem o marco do aumento de estudo envolvendo essa tecnologia. Estes trabalhos citados, deram-se por Barbosa e Roahorse (2007), com VANT para mapeamento em solo estrangeiro, enquanto o estudo de Jorge et al. (2011) aborda o desenvolvimento do VANT para agricultura, no Brasil.

De forma geral, as pesquisas encontradas nos anais no âmbito desse veículo para o sensoriamento remoto, tratavam desde monitoramento e análises até aplicações de segurança e envolvendo até desenvolvimento de tecnologias redução de custo com o VANT.

Ao que se trata das instituições que divulgaram estas pesquisas no SBSR, destacaram-se o INPE com $15,74 \%$ das publicações, Embrapa (5,56\%), institutos da USP $(4,32)$, UnB $(3,40)$ e o IEAv com $2,16 \%$. As demais foram enquadradas como Outros, não por falta de relevância, mas por não terem grandes participações no tema abordado por este levantamento bibliométrico. 0 Gráfico 2 ilustra as contribuições citadas acima, destacando de forma clara a grande contribuição do INPE para o Simpósio.

As instituições encontradas, em grande parte, encontram-se alocadas na região do sudeste brasileiro, no entanto, muito das pesquisas e das áreas estudadas não eram efetuadas na mesma localidade. Sendo assim, constatou-se que as atividades foram exercidas em todos os campos ao longo do Brasil e algumas em território estrangeiro. Essa relação, destacada no Gráfico 3, ilustra a quantidade de estudo exercido em cada região. 
Gráfico 2 - Instituições e empresas com maior contribuição nos anais do SBSR

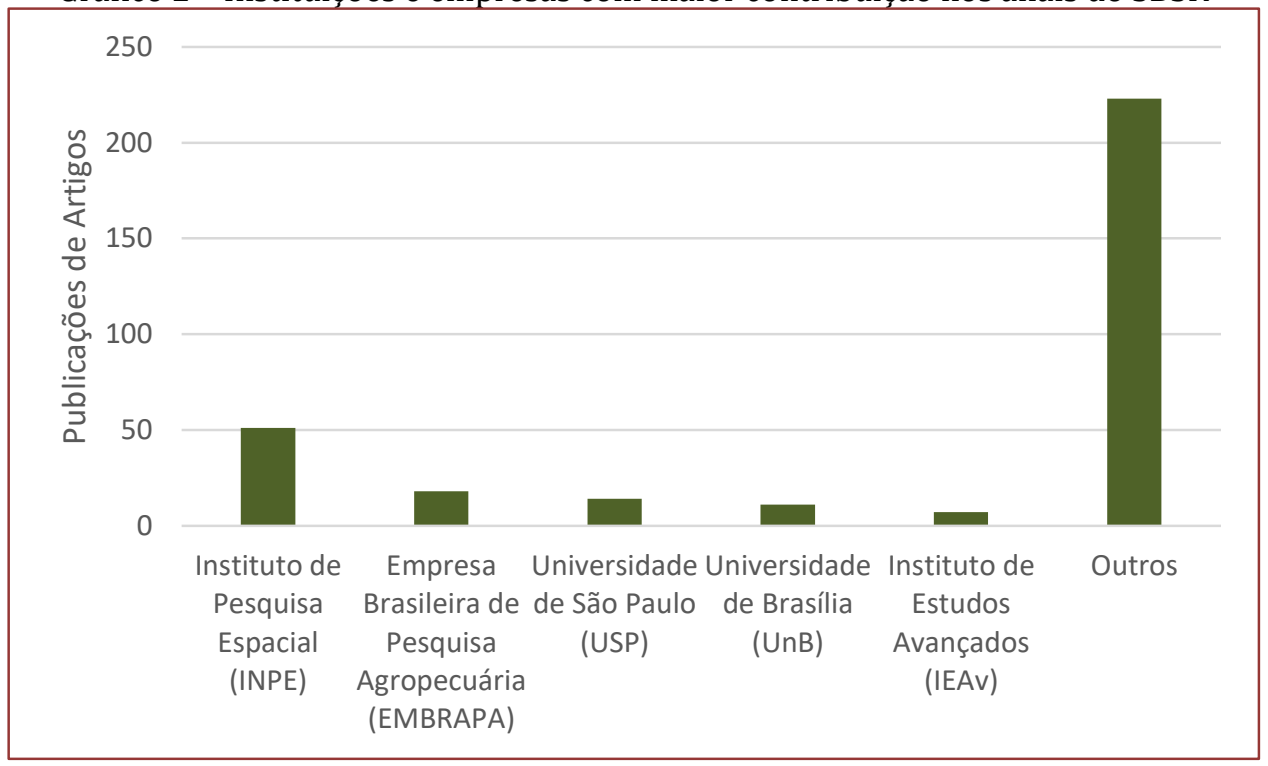

Gráfico 3 - Regiões exploradas pelos artigos.

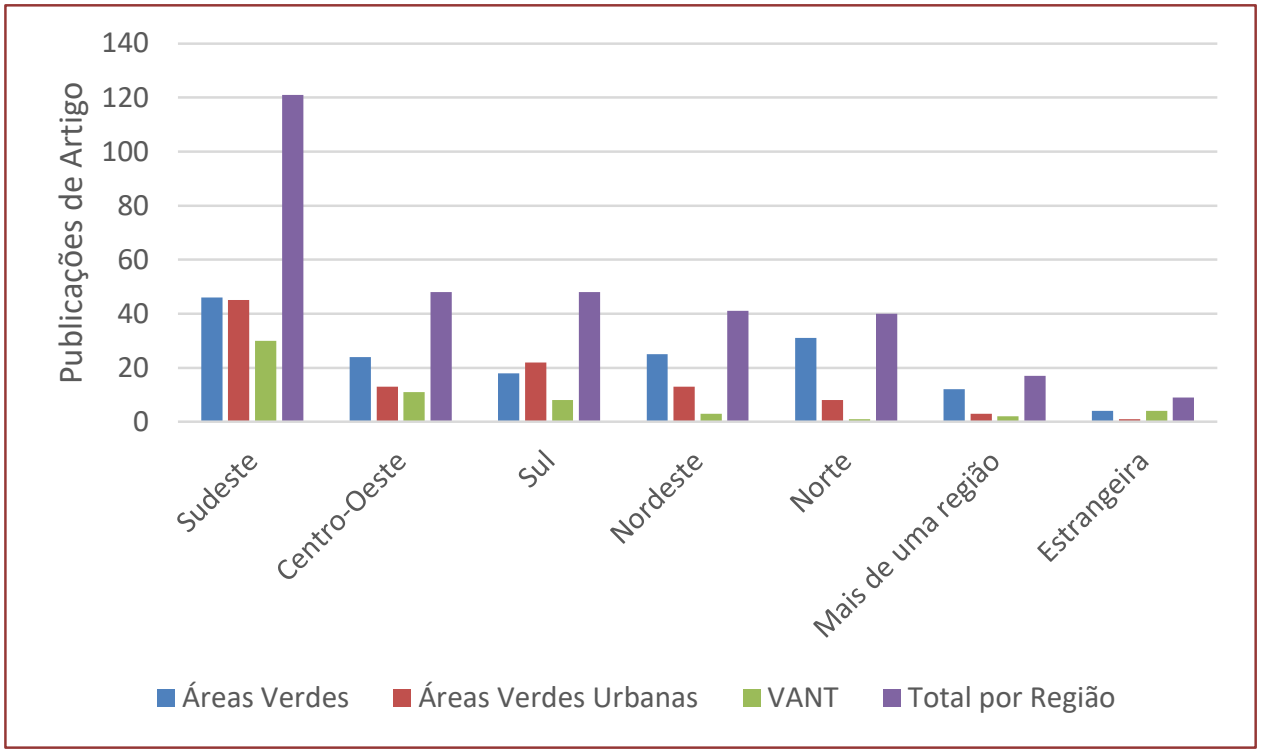

Com o levantamento das regiões abordadas nas publicações do SBSR, observou-se o Sudeste com grande destaque, seguido do centro-oeste. Algumas pesquisas abordavam o mapeamento e análises em áreas mais extensas, como o cerrado, Amazônia e a região que abrange o Maranhão, Tocantins, Piauí e Bahia (MATOPIBA), conhecida por compor grande influência na produção brasileira de grãos e fibras (RAFAEL, 2014). Foi possível identificar também algumas regiões que discorreram mais sobre as Áreas Verdes no âmbito urbano, como na região sul brasileira, no entanto, pode-se observar alto nível de esforços para pesquisas em área urbana na região sudeste.

Já passado pelo número de publicação, institutos e regiões, fez-se importante o conhecimento acerca do tema ou objetivo dos trabalhos analisados, para compreensão dos tipos de atividades de pesquisa, relação do uso e ocupação do solo com a cobertura vegetal e em paralelo o avanço das atividades do VANT. Ao analisar o Gráfico 4, na primeira impressão já é possível notar objetivo de análise (35,82\%) nos artigos como o mais utilizado, principalmente no contexto de Áreas Verdes (56\% do total de análises), em seguida a intenção de mapeamento (25,93\%) de áreas e por final, empatados, o propósito de monitoramento, avaliação e identificação/levantamento com $12,65 \%$ dos temas e objetivos abordados pelas publicações. 
Gráfico 4 - Abordagens em temas e objetivos encontrados nos estudos

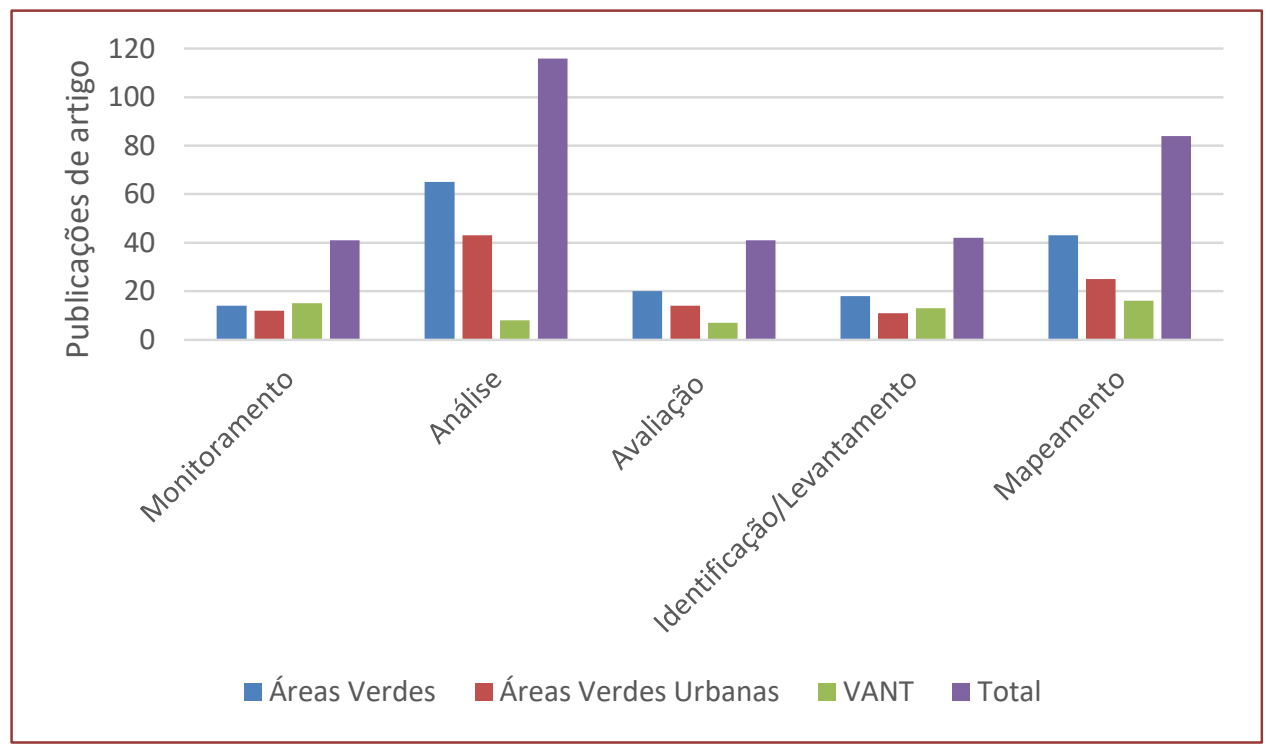

Ao observar as colunas referentes a Áreas verdes, identificou-se altas em análise e mapeamento, demonstrando determinado interesse de compreensão da região estudada, o qual, o mesmo aconteceu ao verificar as colunas das Áreas Verdes inseridas em áreas Urbanas. No entanto, as colunas referentes ao uso de VANT para estas aplicações, identificou-se destaque no mapeamento e monitoramento das áreas, demonstrando interesse de um trabalho mais próximo e in-loco com as áreas estudadas. Ainda sobre o VANT, pode-se notar devida importância nas práticas de identificação e levantamento destas áreas, tomando espaço na área de serviços de geotecnologia.

\section{CONCLUSÃO}

Com o levantamento dos dados e análise sobre as informações obtidas, pode-se concluir que houve grande avanço no desenvolvimento de pesquisas e interesses na área de geotecnologia voltado para estudo de uso e ocupação e cobertura do solo, destacando-se principalmente estudo voltados para fragmentos florestais de uma forma geral. No entanto, ainda pode-se identificar crescimento e destaque da ferramenta geotecnológica utilizada em meio urbano.

Foi possível identificar, além do desenvolvimento das geotecnologias para estudo, análises, monitoramento e dentre outro utilidades, as iniciativas dessas tecnologias auxiliadas pelo uso de VANTs que nos últimos cinco anos passou a tomar seu espaço na área da geociência.

\section{REFERÊNCIAS}

[1] BARBOSA, H. A.; ROANHORSE, A. S. Mapeamento da cobertura vegetal por meio de aeronave não tripulada na estação experimental de Santa Rita em Arizona: Estudo de caso. In: XIII Simpósio Brasileiro de Sensoriamento Remoto, 13., 2007, Florianópolis/SC. Anais... Florianópolis/SC: URLibService. p. 6323-6328.

[2] BARROS, M.S.S.; GUICHOU, C.J. Procedimentos para determinação automática de zonas homogêneas urbanas com dados de sensores à baixa altitude. In: III Simpósio Brasileiro de Sensoriamento Remoto, 3., 1984, Rio de Janeiro. Anais... Rio de Janeiro: URLibService.

[3] CATUREGLI, L. et al. Unmanned aerial vehicle to estimate nitrogen status of turfglasses. Pisa-Itália. Plos One. v.11, no.6, jun. de 2016. ISSN: 1932-6203.

[4] COELHO, V.H.R et al. Dinâmica do uso e ocupação do solo em uma bacia hidrográfica do semiárido brasileiro. PE - Brasil. Revista Brasileira de Engenharia Agrícola e Ambiental. v.18, no.1, p. 64-72, set. 2014. ISSN: 1807-1929.

[5] JORGE, L. A. C.; INAMASU, R.Y.; CARMO, B. C. Desenvolvimento de um VANT totalmente configurado para aplicações em agricultura de precisão no Brasil. In: XV Simpósio Brasileiro de Sensoriamento Remoto, 15., 2011, Curitiba/PR. Anais... Curitiba/PR: URLibService. p. 399-406. 
[6] MENESES, B.M. Análise das alterações do uso e ocupação do solo no Vale do Varosa (Portugal) mediante imagens Landsat-TM e sua influência na conservação do solo. Lisboa - Portugal. GeoFocus (Articulos). no 13-1, p. 270290, ago. de 2013. ISSN: 1578-5157.

[7] MENDOZA, M.E. et al. Analysing land cover and land use change processes at watershed level: A multitemporal study in the lake Cuitzeo Watershed, Mexico (1975-2003). Michoacán - México. Applied Geography. v. 31, p. 237-250. 2011. ISSN: 0143-6228.

[8] MORAES JUNIOR, V.F.; ARAÚJO, A.O.; REZENDE, I.C.C. Estudo bibliométrico da área Ensino e Pesquisa em gestão de custos: Triênio 2007-2009 do Congresso Brasileiro de Custos. Reunir: Revista de Administração, Contabilidade e Sustentabilidade. v.3, no․2, p. 20-38, mai/ago. de 2013. ISSN: 2237-3637

[9] MÖRTBERG, U. M. Landscape Ecological assessment: A tool for integrating biodiversity issues in strategic environmental assessment and planning. Journal of Environmental Management. v.82, no.4. p. 457-470, mar. de 2007. ISSN: 0301-4797.

[10] NETO, F.D.F. et al. Avaliação da qualidade posicional de dados espaciais gerados por VANT utilizando feições pontuais e lineares para aplicação cadastrais. Curitiba/PR - Brasil. Boletim de Ciência Geodésica. v.23, no‥1, p. 134149, jan-mar. de 2019. ISSN: 1982-2170.

[11] NIERO, M.; FORESTI, C.; LOMBARDO, M.A. Utilização de dados Landsat no monitoramento da expansão urbana da grande São Paulo, em áreas de proteção aos mananciais. In: II Simpósio Brasileiro de Sensoriamento Remoto, 2., 1982, Brasília/DF. Anais... Brasília/DF: URLibService. p. 879-896.

[12] RAFAEL, M. et al. Matopiba: Caracterização das áreas com grande produção de culturas anuais. 1. ed. Campinas/SP. 2p. jun. 2014.

[13] RITCHIE, J.C.; ZIMBA, P.V.; EVERITT, J.H. Remote sensing techniques to assess water quality. Photogrammetric Engineering and Remote Sensing. v.69, no.6, p. 695-704, jun. de 2003. ISSN: 0099-1112.

[14] SILVA, F.J.L.T.; ROCHA, F.R.; AQUINO, C.M.S. Geografia, geotecnologias e as novas tendências da geoinformação: Indicação de estudos realizados na região Nordeste. Grajaú/MA - Brasil. Interespaço: Revista de Geografia e Interdisciplinaridade. v. 2, no.6, p. 176-197. ISSN: 2446-6549.

[15] STANGANINI, F.N.; LOLLO, J.A. O crescimento da área urbana da cidade de São Carlos/SP entre os anos de 2010 e 2015: o avanço da degradação ambiental. Revista Brasileira de Gestão Urbana. p. 118-128, out. 2018. ISSN: 2175-3369.

[16] WATANUKI, H.M. et al. Gestão de projetos internacionais: Um estudo bibliométrico. São Carlos/SP-Brasil. Gestão e Produção. v.21, nº.3, p. 660-675, abr. de 2014. ISSN:1806-9649. 


\section{Capítulo 2}

Grandes Projetos Urbanos e a reinvenção das cidades. A implantação de um shopping em Juiz de Fora, MG.

\section{Luciane Tasca}

Resumo: Este trabalho vem apresentar uma revisão e atualização das pesquisas realizadas entre 2008 e 2010, pelo Grupo de Pesquisas em Planejamento Urbano, no projeto intitulado "Grandes Projetos Urbanos em Juiz de Fora: Mapeamento e Estudo Comparativo". Buscando potencializar a centralidade de Juiz de Fora e aumentar a competitividade diante de outros municípios, tanto no âmbito econômico como na prestação de serviços, adotaram-se referências de desenvolvimento urbano através da importação de propostas, modelos e instrumentos de planejamento de outros países. Os chamados grandes projetos urbanos, terminologia presente em diversas literaturas, constituem-se em uma das tendências do empresariamento urbano, evidenciando uma nova maneira de conceber a cidade através da ação pública-privada e do marketing urbano. 0 continuum temporal reflete um momento de inflexão na produção de políticas urbanas, com o aparecimento do que veio a ser sintetizado pela ideia de políticas competitivas, voltadas para a atração de capitais, em concorrência, num contexto de competição interurbana. Adotou-se uma metodologia baseada em análises multidimensionais e na observação de pontos de ruptura em diferentes dimensões do espaço, objetivando um melhor entendimento do processo em pauta e de sua contribuição para o debate sobre a teoria e os métodos do planejamento urbano e regional.

Palavras-Chave: Planejamento Urbano. Grandes Projetos Urbanos. Marketing Urbano

Trabalho originalmente publicado nos Anais do XVI Fórum Ambiental da Alta Paulista. 24 a 26 de junho de 2020. Disponível em <

$r>$

Trabalho originalmente publicado na Revista Nacional de Gerenciamento de Cidades no v. 8, n. 65 (2020). Disponível em

$<$

$>$ 


\section{INTRODUÇÃO}

As perspectiva da atualidade, diante das novas questões como a pandemia do Cornona Vírus, a (in)sustentabilidade econômica e social, e outras, anteriores até à crise atual _ como fragilidade do sistema público em aspectos básicos como saúde, educação, habitação social, infraestrutura_rebatidas no campo do urbano nos levam a repensar o caminho percorrido ao longo do tempo e refinar a buscar por soluções mais sustentáveis para um planeta urbano. Desde as publicações de Jane Jacobs, que de forma pioneira e incisiva, anunciava-se a necessidade de atentar para a vitalidade das cidades, composta principalmente pelo conceito da rua e da diversidade funcional.

Conforme destaca Leite (2012), as grandes cidades "sempre enfrentaram seus ciclos de decadência e ressurgimento, reinvenção", e o desenvolvimento sustentável, entendido como aquele em que a paisagem natural e o espaço construído se inter-relacionam de forma integrada e harmônica para ambas as partes. Essa é a pauta das discussões do século 21, a reinvenção das cidades com propostas mais inteligentes "do que as que cresceram e se expandiram sem limites no século 20" (LEITE, 2012).

Este trabalho vem apresentar uma revisão e atualização das pesquisas realizadas entre 2008 e 2010, pelo então GPUR (Grupo de Pesquisas em Planejamento Urbano), da Universidade Federal de Juiz de Fora, Faculdade de Engenharia, Departamento de Arquitetura e Urbanismo ${ }^{1}$. 0 projeto de pesquisa ${ }^{2}$, intitulado "Grandes Projetos Urbanos em Juiz de Fora: Mapeamento e Estudo Comparativo", analisou 4 grandes projetos urbanos na cidade, justificados como necessários para aumentar a competitividade em relação a outros municípios e consolidar Juiz de Fora, no estado de Minas Gerais, como polo da Zona da Mata Mineira.

Juiz de Fora é uma cidade que vem desde os anos 90, buscando referências de desenvolvimento urbano através da importação de propostas, modelos e instrumentos de planejamento de outros países. Este fato, comum na nossa história, merece críticas e questionamentos a respeito, pois sendo elaborados em universos econômicos, políticos e culturais, diferentes, tais concepções não são neutras, na medida em que estruturam relações e representam uma realidade sócio-espacial que projetam uma receita única para realidades completamente diversas (TASCA, 2010).

Os chamados grandes projetos urbanos (GPU's), terminologia presente em diversas literaturas, constituem-se em uma das tendências do empresariamento urbano (HARVEY, 1996), evidenciando uma nova maneira de conceber a cidade através da ação pública-privada e do marketing urbano (SÁNCHEZ, 1997).

Sua definição, entretanto, faz parte das pesquisas urbanas que fomentam a discussão sobre o assunto. Mas apesar das especificidades de cada sítio, segundo Cuenya et al (2013),

os estudiosos concordam em que existe uma nova camada ou família, ou geração de megaprojetos, que surgiram e se disseminaram nos últimos 30 ou 40 anos, na maioria das grandes cidades do mundo, com fisionomia ou rasgos físico-funcionais quase idênticos: escritórios em arranha-céus, residências de luxo, hotéis de altíssimo padrão, shopping centers, espaços culturais e de lazer.

A partir dos anos 90 com o processo de globalização tomando conta do cenário mundial, observou-se a disseminação das regras de livre mercado, passando a economia a ser progressivamente isenta do controle político, resultando em uma ação do Estado somente na regulação das intervenções e no controle das pressões locais (BAUMAN, 1999).

A própria questão urbana foi reinterpretada, passando a sustentar-se na valorização das vantagens competitivas e das estratégias de desenvolvimento local, destacando-se as formas de divulgação através

${ }^{1}$ O GPUR foi coordenado pelo professor Pedro de Novais Lima Junior até 2010, quando esta autora assumiu o grupo, sendo o mesmo extinto tempos depois. Atualmente, o antigo departamento de Arquitetura e Urbanismo da Faculdade de Engenharia da UFJF, se constitui na Faculdade de Arquitetura e Urbanismo FAU/UFJF e o grupo de pesquisa Laboratório da Paisagem (LAPASA) atua nessa área.

20 projeto de pesquisa iniciou suas atividades em 2008, sob a coordenação professor Pedro de Novais Lima Junior, até 2010 , quando passamos a assumir os trabalhos. Necessária menção aos bolsistas PROBIC/UFJF/FAPEMIG, Nicole Andrade da Rocha, Thiago da Silva Andrade e a bolsista de Apoio Técnico, Marcela Caixeiro Mattos. 
da valorização do discurso e na utilização do modelo de cidade competitiva como forma de obtenção do sucesso (VAINER, 2000).

Complementando esse pensamento, percebemos que o processo de mudanças na política urbana e a guinada para o empresariamento, acabam por levar ao surgimento de atividades e serviços que se consolidam através de empregos de baixa remuneração, contribuindo assim para o aumento das disparidades entre riqueza e pobreza urbanas. É possível perceber várias tentativas dos governos urbanos de inovarem e de se tornarem mais empreendedores, reorientando suas atitudes em relação à administração urbana, baseando suas políticas na competição entre localidades, estados e regiões. Dessa forma, os governos das cidades assumem um comportamento empresarial em relação ao desenvolvimento econômico e passam a se preocupar de forma mais intensa com novas estratégias de crescimento (HARVEY, 1996).

Em Juiz de Fora (MG), objeto desse trabalho, nota-se esse processo sobretudo por suas leis e planos elaborados, que proporcionaram, grosso modo, ao longo de sua história a requalificação da cidade, levando consequentemente, à valorização da terra e à expansão das fronteiras urbanas.

Nessa cidade, no que diz respeito às ações de planejamento urbano, desde 1977 a Prefeitura contava com um órgão específico, o Instituto de Pesquisa e Planejamento (IPPLAN), sendo que a partir de uma reforma administrativa em 2000, as ações e políticas urbanas passaram a ser geridas pela Secretaria de Planejamento e Gestão Estratégica (SPGE).

Em 1996, o IPPLAN/JF será responsável pela elaboração de uma proposta para o Plano Diretor de Desenvolvimento Urbano, que contava com a revisão das Leis Urbanísticas de 1986. Este processo não se concretizará, sendo o órgão extinto e passando-se o encargo da elaboração e aprovação do Plano Diretor à SPGE, que o fará em 2000 (TASCA, 2010).

Neste contexto, todo o processo de elaboração e aprovação do Plano Diretor de Desenvolvimento Urbano (PDDU, 2000), apresenta-se em Juiz de Fora marcado por contradições, principalmente no que cabe à aprovação do mesmo sem o conteúdo das leis urbanas de uso e ocupação do solo.

Durante o ano de 1997 (sobrepondo-se à elaboração do PDDU, 2000), outra equipe da PJF passou a elaborar o chamado Plano Estratégico de Juiz de Fora (PlanoJF), contando com parcerias público-privadas como forma de alavancar projetos específicos que fossem capazes de desenvolver atividades produtivas diversificadas, como a indústria do conhecimento e do agronegócio (TASCA, 2010).

Buscando potencializar a centralidade de Juiz de Fora e aumentar a competitividade diante de outros municípios, tanto no âmbito econômico como na prestação de serviços, o PlanoJF abrangia projetos para o desenvolvimento econômico e profissional, através da expansão do acesso a educação básica, ao emprego, promovendo a inserção social. Existia ainda a busca de consolidar a cidade como polo da Zona da Mata.

Este processo, confuso e fragmentado, em termos administrativos, não difere das ações do poder público em cidades brasileiras e reforça a ideia de que os municípios menores tendem a seguir os modelos das grandes metrópoles.

As dificuldades e limitações históricas para a ação de planejamento democrático na sociedade brasileira e, em Juiz de Fora, foram e continuam sendo palco de debates, revelando as inúmeras limitações à elaboração de propostas alternativas (democráticas e igualitárias). Diante da impossibilidade de se tomar o ambiente construído de forma independente da sociedade que o constrói e o ocupa, o espaço urbano reflete as relações sociais participando ativamente de sua reprodução. Nesse sentido ele é objeto e agente de permanências e de mudanças influenciando e sendo influenciado pelas relações sociais.

É importante destacar que, cabe ao Poder Público, a capacidade legislativa de induzir ou direcionar o desenvolvimento urbano. No seu princípio de impedir certos padrões de ocupação do solo, a ação da lei fica restrita conforme a capacidade política ou administrativa para se fazer valer as normas prescritas. Por outro lado, em relação a indução do crescimento, ou direcionamento, as possibilidades são ainda mais remotas. Cardoso (1996, p.78) enfatiza que "a produção empresarial tem fortes condicionantes macroeconômicos e institucionais e esses são os fatores mais relevantes para a alteração de sua dinâmica".

Dentre os planos e projetos das gestões urbanas em Juiz de Fora, pode-se destacar no PlanoJF uma forte tendência à uma visão empresarial, calcada em políticas voltadas para o desenvolvimento econômico, inserção e atração da cidade em novos mercados, e confirmação de seu papel polarizador.

Muitas das inovações e investimentos destinados a tornar as cidades atraentes foram utilizadas de forma semelhante em vários lugares do mundo. 0 emblema do marketing urbano, salientando as vantagens 
competitivas dentro de uma rede de cidades, serve assim, para desviar o foco central dos problemas urbanos, como a falta de moradia e a desigualdade social e espacial. Diante do espaço urbano capitalista em que vivemos o princípio da soberania popular, reconhecido teoricamente na lei maior, revela-se na prática, em alguns atos formais de legitimação das decisões aleatórias tomadas por parcelas menores da sociedade (MARTINEZ, 1997). Sem a visão, ou a compreensão clara dessas realidades, que permanecem obscurecidas para a maioria, os cidadãos inseridos nos processos econômicos que estruturam o meio urbano, constroem e reconstroem a cidade a partir das leis de mercado, fundamentadas na lógica fundiária e na renda da terra.

\section{OBJETIVOS}

Os projetos urbanos de grande porte implicam em reestruturações nas diversas dimensões do espaço social, desencadeando a mobilização de atores diversos. Além disso, são capazes de redesenhar os espaços urbanos, atingindo efeitos para além de sua circunscrição imediata, implicando ainda, em uma reafirmação ou produção de novas centralidades.

Num âmbito geral, para avaliar os impactos objetivos e simbólicos, de grandes projetos urbanos em Juiz de Fora, tomou-se como ponto de partida para a definição dos mesmos, aqueles que 1) tivessem manifesto caráter estratégico e desenvolvimentista; 2) fizessem referência, em suas justificativas, a escalas espaciais que transcendessem a esfera local; 3) envolvessem montante significativo de recursos aplicados; 4) fossem resultado da articulação de atores diversos, particularmente no que diz respeito às parcerias entre os setores privado e público e, finalmente, 5) tivessem a pretensão de produzir um impacto estruturante no espaço urbano.

O continuum temporal definido como recorte (1992-2006) foi delimitado, em seu início, por um momento de inflexão na produção de políticas urbanas, com o aparecimento do que veio a ser sintetizado pela ideia de políticas competitivas, voltadas para a atração de capitais, em concorrência, num contexto de competição interurbana. Assim, objetivou-se um melhor entendimento da situação dos projetos em pauta e da contribuição que eles aportam para o debate sobre a teoria e os métodos do planejamento urbano e regional na contemporaneidade.

Como parte de um objetivo mais amplo do projeto de pesquisa referenciado, aqui, teve-se a intenção de apresentar um mapeamento geral dos GPU's em Juiz de Fora, enriquecendo-se a discussão, com a análise de um estudo de caso de um Shopping Center na cidade.

Ressalta-se que os critérios adotados para a seleção desses GPU's foram:

- Situação geográfica;

- Atendimento de um amplo espectro de objetivos que o projeto;

- Análise de um amplo espectro de tipologias (destinação; ocasião) e de situações (em início, recémimplantado, consolidado);

- Visibilidade do empreendimento (divulgação e reconhecimento pela mídia, etc.);

- Verificação preliminar das fontes de informação disponíveis sobre os projetos preliminarmente identificados e de interlocutores confiáveis representativos de diferentes grupos sociais e de perspectivas e interesses sobre o projeto em análise.

Salientando que a discussão conceitual e terminológica é importante para garantir o rigor do processo de objetivação, pelo qual se discrimina o objeto contra a diversidade de práticas relacionadas à intervenção na cidade, recuperou-se na literatura sobre os Grandes Projetos de Desenvolvimento Urbano, elementos pelos quais este conceito possa ser estruturado.

Para Moulaert, Rodríguez, e Swyngedouw, os GPU's constituem nexos para a "localização do global e a globalização do local" (2003, p.7), isto é, pontos da articulação de escalas e a interseção de processos econômicos sociais e políticos, concretizados em esquemas urbanos e ambientes socio-econômicos e institucionais, e produzidos na interação e embate entre forças globais, nacionais e locais. Em contraste com as grandes intervenções urbanísticas do passado, pensadas como adaptações no meio físico para adequá-lo às demandas econômicas, os GPU's visam a uma reestruturação do espaço em suas diferentes dimensões (física, socio-econômica, política, cultural e simbólica). Eles são intervenções no meio físico que pretendem servir como espécies de catalisadores, capazes de alavancar o desenvolvimento econômico local ou regional (MOULAERT; RODRIGUEZ; SWYNGEDOUW, 2003; p.42). Garay (2004) com base na 
experiência francesa, sugere que o GPU prevê a aplicação de diferentes instrumentos sob marco claramente pautado. Trata-se de acionar e articular um conjunto de diferentes instituições e atores tanto do setor público quanto do privado, ao longo de uma sequência de operações. A partir da experiência espanhola da década de 80, observa que, na elaboração de um GPU, aposta-se nas propriedades indutivas de tais intervenções, valorizando sua capacidade de desencadear grandes transformações. As operações pontuais (acupunturais) ${ }^{3}$ urbanas dependem da compreensão que se tenha do comportamento geral do sistema urbano e da capacidade de se identificar os pontos chave de intervenção. Desse modo, para o autor, GPU é uma intervenção sobre um espaço da cidade, que deverá interferir sobre processos sócioespaciais e servir de referência capaz de ordenar a participação de diferentes atores em torno de determinados objetivos, com o propósito de deslanchar transformações sobre o entorno ou sobre tendências gerais do desenvolvimento urbano.

Podemos entender ainda que a noção de GPU contempla tanto obras de efeito simbólico, como grandes operações urbanas, eventualmente na forma de programas de intervenção, que produzam impacto no desenvolvimento de uma cidade. Não se trata, portanto, de uma tipologia padrão, mas de uma forma de atuação pública sobre um segmento da cidade, formulada e implantada em referência a uma visão global da mesma e a questões econômicas e sociais (LUNGO, 2004). Assim como Garay, Lungo considera que a intervenção permitirá uma mudança significativa na cidade, de modo que o GPU pode ser considerado um "programa motor", alavanca para o desenvolvimento local (LUNGO, 2004b; p.21).

Por outro lado, há um aspecto de objetividade que torna os GPU's atraentes para os investidores privados: um tal empreendimento é concebido em termos de uma intervenção precisa no território, o rigor que essa forma evidencia, garante que diferentes atores, públicos ou privados, mas geralmente sob a coordenação do poder público, tenham elementos de referência para sua ação e possam agir consensualmente (LUNGO 2004b; p. 18-19). Não é apenas Lungo (2004) quem chama a atenção para o papel de liderança do Estado. Arias (2001), Altshuler e Luberoff (2003), entre outros, observam que os GPU's são intervenções do poder público na ordenação da cidade.

O papel da arquitetura, enquanto elemento estético e de comunicação (dimensão simbólica) é observado por vários autores, sendo que a imagem do empreendimento pode ser associada à imagem da cidade (PORTAS, 2003; LUNG0, 2004b). A questão do porte é relevante para muitos autores, observando-se que o adjetivo "grande" constituiria o elemento a conferir a especificidade dessa forma de agir. Segundo Garay (2004) um GPU não pode ser definido pela envergadura (porte) do empreendimento, enquanto Lungo, como já observado, sugere que o porte está relacionado à complexidade _de relações, tecnologias, formas das operações de financiamento, etc._que suscita (2004b). Para Altshuler e Luberoff o termo megaprojeto foi cunhado pelo governo canadense no final dos anos 70 e identifica, no estudo que os autores desenvolvem, empreendimentos de custo acima de US\$250 milhões (valores de 2002) (ALTSHULER e LUBEROFFF, 2003). Esses autores têm, entretanto, um outro parâmetro em sua conceituação: um megaprojeto é um projeto de iniciativa pública envolvendo intervenções físicas e de planejamento da cidade que, por sua magnitude cria efeitos de ruptura no espaço urbano e, portanto, desperta conflitos que tendem a inviabilizá-lo. Um GPU nessa ótica se define menos pelo volume de recursos e mais pelo impacto que gera ou, espera-se, irá resultar. Essa é também a opinião de Sandroni, para quem um GPU não se caracteriza apenas pela elevada quantidade de dinheiro envolvida na sua implementação, mas por uma série de outros fatores, sendo o mais importante o impacto na mudança de vocação de uma determinada área da cidade e/ou mudança no dinamismo da atividade imobiliária (SANDRONI, 2004; p.148).

Se a história recente do urbanismo e do planejamento urbano no Brasil revela que a cidade foi tratada como lugar da produção de desigualdades sociais (VAINER, 2000), a emergência dos Projetos Urbanos, acompanhando o surgimento dos discursos sobre a atração de capitais, como forma de garantir e sustentar o desenvolvimento local, indica uma perspectiva diferente quanto ao papel da cidade e a problemática urbana e a ampliação da escala geográfica tomada por referência nas decisões sobre as políticas para os municípios. A mudança vale-se da asserção de um contexto de novas transformações sobre o tecido urbano, sujeito ao processo de formação de um espaço globalizado que articula os lugares em parte pela disposição extensiva de infraestruturas de transporte e comunicação.

Tomar a escala global por referência implica o reconhecimento de um número crescente de atores em operação e da dificuldade para atingir decisões aceitáveis num ambiente onde intensificou-se a complexidade. Supõe, assim, o recurso a múltiplas competências e técnicas, inclusive de coordenação e negociação de conflitos e interesses entre os atores participantes.

${ }^{3}$ Ver LERNER, Jaime. Acupuntura Urbana. Rio de Janeiro: Record, 2003. 
Assim, a cidade tem sido palco de experimentações pretensiosas: reestruturação do espaço, renovação de zonas portuárias, revitalização de áreas centrais, intervenções acupunturais para a regeneração do tecido urbano, implementadas simultaneamente, em diferentes lugares, evidenciam a dominância de uma mesma resposta a uma problematização igualmente dominante da questão urbana: o ajustamento da cidade industrial às determinações do terciário avançado e a seu reposicionamento em relação à nova geografia da competição do mundo globalizado (BORJA e CASTELLS, 1997; LUNGO, 2004a; MOULAERT, RODRÍGUEZ, e SWYNGEDOUW, 2003).

Em suma, muitas são as evidências que apontam para mudanças no planejamento urbano, enquanto forma de ação do Estado sobre o território, demonstrando a prática do planejamento por projetos, e suas implicações sobre os espaços físico e social, em suas múltiplas dimensões, contribuindo para a consolidação de mudanças na dinâmica sócio-espacial, caracterizada por reconfigurações escalares e efeitos de desenvolvimento desigual na escala local.

A percepção da dinâmica das transformações no espaço urbano construído nos fornece subsídios para a reflexão sobre as possibilidades e limites de políticas que visem ao controle e direcionamento do crescimento e desenvolvimento urbano. Tal suporte nos permite ter elementos para avaliar, ponderar e diagnosticar as mudanças relevantes na conformação de uma cidade

\section{METOdOLOGIA / MÉTODO DE ANÁLISE}

Como já mencionado anteriormente, este trabalho partiu das pesquisas realizadas de 2008 a 2010 , no Projeto de Pesquisa "Grandes Projetos Urbanos em Juiz de Fora: Mapeamento e Estudo Comparativo", tendo por princípio uma análise multidimensional que supõe a observação de pontos de ruptura em diferentes dimensões do espaço, permitindo, ainda, a sistematização e comparação de dados em futuras pesquisas com outros projetos urbanos. ${ }^{4}$

Num primeiro momento, trabalhou-se com a dimensão política, relacionada ao contexto sócio-político (município, estado) da emergência e/ou da implantação do projeto, procurando identificar as coalizões políticas locais e aquelas formadas a partir do mesmo.

A segunda dimensão foi a institucional, relacionada aos processos decisórios e de controle social na montagem e na implementação do projeto, aos atores e parcerias, aos dispositivos legais e inovações institucionais implementadas e às relações entre esferas governamentais. Nesta análise buscou-se identificar as mudanças nas instituições vigentes para acomodar os projetos estudados.

A seguir, a dimensão simbólica aparece relacionada à economia simbólica dos projetos, sua ordem de justificação, referências conceituais, matrizes, valores e representações acionados para fundamentar, justificar e orientar sua implementação, além das retóricas, discursos em disputa e linguagens empregadas.

Consecutivamente, a dimensão arquitetônico-urbanística-regional foi relacionada aos agentes e às referências urbanísticas para o projeto. Abordou-se também, a concepção do programa, o partido arquitetônico/urbanístico, a linguagem arquitetônica adotada, as obras de infraestrutura planejadas e executadas e, por fim, os instrumentos urbanístico/fundiários associados ao uso e ocupação do solo.

Relacionada às mais-valias imobiliárias mobilizadas a dimensão fundiária se ateve ao modo como aquelas foram geradas, apropriadas e utilizadas, bem como à transformação na estrutura fundiária e aos processos de incorporação de terra.

Pauta de debates atuais abordou-se também a dimensão sócio-ambiental-territorial, relacionada à distribuição pelo território dos impactos econômicos (geração de emprego e renda), ao acesso social e controle público dos equipamentos, além dos impactos ambientais.

Por fim, relacionada às modalidades de financiamento, aos modos de exploração econômica dos empreendimentos e aos seus impactos do ponto de vista fiscal, aborda-se a dimensão econômico-

\footnotetext{
${ }^{4}$ A pesquisa apresentada, e sua metodologia, se baseiam em estudos desenvolvidos por um conjunto de pesquisadores de diferentes instituições de ensino, pesquisa e planejamento do território no Brasil, buscando-se uma atualização para o caso de Juiz de Fora, MG. Dentre as atividades desses estudos destaca-se a pesquisa "Grandes Projetos Urbanos, o que se pode aprender com a experiência brasileira?", financiada pelo Lincoln Institute of Land Policy, as Sessões Livres nos Encontros Nacionais da ANPUR de 2003 (Belo Horizonte), 2005 (Salvador) e 2007 (Belém), um Workshop com os pesquisadores envolvidos com o tema (2005, Rio de Janeiro) e o Seminário Nacional: “Grandes Projetos Urbanos, o que se pode aprender com a experiência brasileira?” (2006, Rio de Janeiro). Acumularam-se, nos estudos e encontros realizados, além de amplo domínio da produção bibliográfica sobre os Grandes Projetos Urbanos, elementos para uma identificação preliminar desses projetos no município
} 
financeira, procurando-se identificar o montante de investimento público para viabilizar o projeto e seus possíveis efeitos multiplicadores.

\section{RESULTADOS}

\subsection{PLANEJAMENTO POR PROJETOS: O CASO DE UM SHOPPING EM JUIZ DE FORA, MG}

\section{DIMENSÕES DE ANÁLISE}

Destacamos que em relação ao contexto Sócio-Político do município e às coalizões formadas, o GPU do shopping foi idealizado por um grupo específico de investidores locais que vêm se fortalecendo e conquistando maior espaço nas decisões políticas da gestão urbana. 0 projeto resultado de uma obra com caráter privado, estabeleceu parceria junto à Prefeitura Municipal de Juiz de Fora, desde o processo de implantação. Tais medidas foram determinantes para a viabilização do empreendimento, destacando-se a concessão pelo município de isenções fiscais e operações urbanas.

Ao analisarmos matérias veiculadas na imprensa local, ${ }^{5}$ pudemos identificá-las como elemento na legitimação de ideias e interesses de atores específicos, a associando-se o empreendimento aos conceitos de desenvolvimento, oportunidades de emprego, garantindo maior adesão popular. As notícias sobre o empreendimento passaram a ser veiculadas a partir de 2003, quando as primeiras movimentações de terra começaram a ser feitas, mas o volume de reportagens só tomou maiores proporções quando em 2005, foi concretizada a permuta entre terrenos da Prefeitura e a empresa proprietária do empreendimento. Este foi também o período em que a imprensa se encarregou de mostrar o interesse dos vereadores e do executivo no processo, mostrando também os valores da permuta, ressaltando a diferença monetária que deveria ser repassada à Prefeitura, uma vez que a avaliação dos seus terrenos foi maior que as da empresa. Vale destacar que, quando as permutas eram pauta, havia sempre uma consideração onde se destacava e ficava bem clara a ideia de que tal ação não traria prejuízos financeiros aos cofres públicos. As reportagens que se seguiram traziam informações comentando sobre os sócios e os outros empreendimentos do grupo e ainda sobre as condições do tráfego, uma vez que a área já apresentava um fluxo considerável de pessoas e carros (por ser um dos acessos à UFJF, BR-040 e Estádio Regional). Esta consideração sobre o tráfego veio junto com a colocação de que tal área permitiria a construção de novos módulos horizontais e verticais, passíveis de acontecer nos próximos 30 anos, num projeto de ampliação do shopping.

Podemos destacar que em momento algum foram colocados nas reportagens estudos sobre impactos sócio-ambientais na região de instalação.

Na chamada curva do Lacet, ${ }^{6}$ anel viário próximo ao local, onde antes existia um campo de futebol de várzea, veiculou-se na mídia apenas que, no lugar do campo, haveria a implantação de praça pública, urbanizada, arborizada e com local para realização de eventos públicos, para a prática de atividades físicas, lazer infantil e dotado de quadra poliesportiva. 0 que podemos comprovar até hoje em dia é que o local serve apenas de passagem e não apresenta nenhum dos equipamentos descritos, muito menos a estrutura necessária para eventos públicos. ${ }^{7}$

No que cabe à Dimensão Institucional, podemos dizer que o processo de implantação do shopping pertence a um contexto maior atrelado à gestão urbana em Juiz de Fora e às práticas estabelecidas através dos Planos Diretores e Estratégico. Percebemos que no caso específico do projeto em análise, o envolvimento do poder público foi determinante, como já mencionado na dimensão política, havendo inclusive operações urbanas que possibilitaram alterações na legislação de uso e ocupação do solo.

Diante da Dimensão Simbólica, destacamos as informaç̧ões vinculadas nos panfletos de divulgação do shopping center, onde pudemos perceber a ideia de atender a uma demanda não só local, mas também regional (Zona da Mata e cidades do Estado do Rio de Janeiro), destacando o empreendimento como

\footnotetext{
${ }^{5}$ Além disso, ainda nesse âmbito, através de informações referentes ao processo de implantação do shopping nos jornais impressos de maior circulação na cidade, pudemos obter um referencial cronológico, sendo possível acompanhar os primeiros indícios de construção, passando pelos períodos de paralisação das obras, até a sua inauguração e pleno funcionamento (Disponível em $<\mathrm{http}: / /$ www.tribunademinas.com.br e <http://www.panoramajf.com.br>).

${ }^{6} 0$ terreno da chamada curva do Lacet se localiza bem em frente ao shopping em questão, tendo sido, antes do empreendimento, uma área esportiva e de lazer com parquinho e campo de futebol de várzea, utilizado pelos moradores do bairro Dom Bosco, caracterizado por população de baixa renda.

${ }^{7}$ Apesar de veiculada pelos jornais locais, a informação sobre a implantação de praça com equipamentos de lazer não consta da Lei 11404 / 2007 de 24/07/2007 que Institui a "OPERAÇÃO URBANA Independência Shopping”, alterando parâmetros urbanísticos na área que especifica. Processo 01767/2007 vol. 01.
} 
pioneiro neste segmento na cidade, embora não o fosse. Nas palavras dos investidores e de alguns representantes do poder público, o shopping seria um dinamizador econômico sendo responsável pelo aumento de oportunidades de empregos e representando um novo momento para cidade, em uma nova era de desenvolvimento.

Diretamente relacionada aos agentes a Dimensão Arquitetônica-Urbanística-Regional se manifesta nas questões de infraestrutura e aos instrumentos urbanísticos/fundiários associados ao uso e ocupação do solo. Além dos impactos urbanísticos e ambientais nas diversas escalas, destacamos a importância destes projetos à arquitetura de grife, onde renomados arquitetos são contratados para que a obra tenha a notoriedade e o alcance desejados. No caso em questão, um grupo responsável por estabelecimentos comerciais deste porte em grandes centros urbanos, foi contratado para executar a obra. Este grupo é responsável por padronizações, onde modelo de lojas, praças de alimentação, estacionamento, seguem uma linha, por isso a semelhança entre alguns shoppings centers no país. No que tange ao elemento urbanístico, destacamos a promoção de uma nova centralidade na cidade, onde a concentração de investimentos imobiliários, tem se tornado cada vez mais evidente e constante.

No tocante à Dimensão Fundiária, a partir da observação, podemos destacar que o projeto promoveu um aumento considerável na valorização imobiliária na região, acompanhado de intensa produção do espaço urbano.

A Dimensão Sócio-Ambiental-Territorial se relaciona à distribuição pelo território dos fatores econômicos (geração de emprego e renda), ao acesso social e controle público dos equipamentos, bem como a relevância ambiental. Sendo assim, a possível distribuição pelo território dos impactos positivos advindos do funcionamento do shopping foram diluídos pela isenção cedida aos lojistas por dez anos, diminuindo neste período, a possibilidade de gerar melhorias urbanas na região.

Ambientalmente, as leis vigentes foram contempladas, salientando-se que a legislação urbana (lei de uso e ocupação do solo, lei do parcelamento do solo e edificação), data de 1986, sendo bastante deficitária e desatualizada para o contexto atual. No que cabe à questão social a construção do shopping trouxe à tona questões polêmicas, uma vez que um dos bairros vizinhos representa uma área de interesse social, apontando-se para possíveis processos de segregação evidenciados a partir da implantação do projeto.

Podemos destacar por fim, sob o aspecto da Dimensão Econômico-Financeira, que, para a cidade, o montante investido no projeto, foi de grande volume, ficando a discussão, entretanto, um pouco mais restrita, por se tratar de uma obra com investimento privado, sendo que o auxílio do poder público, se deu de forma indireta (permutas, isenções fiscais, etc.).

\section{CONCLUSÃO}

De acordo com Villaça (1999), o plano-discurso cumpre um papel ideológico, ocultando os reais motivos que influenciam os investimentos urbanos, representando assim, a fragilidade da legislação urbana e se constituindo num instrumento para o exercício arbitrário do poder, favorecendo interesses particulares. Assim, a ilegalidade e a segregação sócio-espacial que caracteriza o padrão de ocupação é funcional para o sistema, através da manutenção do baixo custo de reprodução da força de trabalho, favorecendo o mercado imobiliário especulativo (MARICATO, 2000).

0 reflexo espacial desse processo se revela através da concentração espacial de renda e de investimentos públicos em partes específicas da cidade, especialmente as centrais dotadas de maior qualidade de serviços e infraestrutura. Os segmentos de menor poder aquisitivo, por outro lado, acabam por se localizar nas áreas mais distantes, mais condizentes com sua faixa de renda. Colaboram para manutenção desse processo, aumentando as disparidades entre as camadas sociais, os investimentos públicos que tendem a ser implementados em áreas já dotadas de infraestrutura, atendendo aos interesses do capital especulativo.

Dentro desse panorama podemos localizar a dinâmica da produção do espaço urbano em Juiz de Fora, envolta por ações fragmentadas sobre a legislação urbana e sobre os planos e projetos apresentando, ao mesmo tempo, um quadro de crescimento urbano, pelo menos no que diz respeito aos vários empreendimentos que a cidade vê surgir a cada dia, inclusive com investidores externos (TASCA, 2010).

0 equipamento urbano objeto deste artigo localiza-se em uma das principais avenidas e porta de entrada/saída da cidade, possuindo grande visibilidade na cidade e entorno. A inauguração, prevista para o mês de abril de 2008, foi ansiosamente esperada, tanto por consumidores, quanto por lojistas localizados no centro da cidade. Para os primeiros, bem como para os administradores da cidade e para 
boa parte da imprensa, o shopping se tornaria mais uma atração sendo capaz de atrair consumidores da região da Zona da Mata. Para os outros, o empreendimento atrairia o público consumidor da área central, contribuindo para o esvaziamento da mesma, o que não se consolidou.

Compondo um cenário que revela e reitera o quadro urbano brasileiro, no aspecto da produção do espaço urbano, os elementos que envolveram os processos de aprovação e implantação do shopping e, a estreita vinculação entre os poderes público e privado, conformam uma parceria que se destaca nas pesquisas sobre grandes projetos urbanos.

Buscando apenas sinalizar um importante caminho e apontar para o início de uma conclusão sobre o assunto, pode-se entender que sob a lógica do modo de produção capitalista, as cidades de médio porte, como Juiz de Fora, repetem o esquema produtivo especulativo baseado na relação público-privada e no marketing urbano entendidos como caminho prioritário para o desenvolvimento urbano.

\section{AGRADECIMENTO}

Agradeço à Universidade Federal de Juiz de Fora (UFJF).

Agradeço à Fundação de Amparo à Pesquisa do Estado de Minas Gerais (FAPEMIG) pelo fomento à pesquisa.

Agradeço à Faculdade de Arquitetura e Urbanismo (FAU).

Agradeço ao grupo de pesquisa Laboratório da Paisagem (LAPASA)

\section{REFERÊNCIAS}

[1] ALTSHULER, Alan; LUBEROFF, David. Megaprojects. The changing politics of urban public investments. Washington: Brookins Institution Press, Lincoln Institute of Land Policy, 2003.

[2] ARIAS GOYTRE, Felix. Concertações e operações urbanas: a experiência espanhola. In: ABRAMO, Pedro. Cidades em transformação: entre o plano e o mercado experiências internacionais em gestão do uso do solo urbano. Rio de Janeiro: Observatório Imobiliário de Políticas do Solo, 2001.

[3] BAUMAN, Zygmunt. Globalização: as consequências econômicas. Rio de Janeiro: Jorge Zahar Ed, 1999.

[4] BORJA, Jordi; CASTELLS, Manuel. Local y Global. La gestión de las ciudades en la era de la información. Madrid: United Nations for Human Settlements, Taurus, Pensamiento, 1997.

[5] CARDOSO, Adauto Lucio. Dualização e reestruturação urbana: o caso do Rio de Janeiro. Rio de Janeiro: Observatório de Políticas Urbanas: IPPUR/FASE, 1996.

[6] CORRÊA, Roberto Lobato. O Espaço Urbano. São Paulo, Ática. 2009.

[7] CUENYA, Beatriz; NOVAIS, Pedro; VAINER, Carlos. Grandes Projetos Urbanos: olhares críticos sobre a experiência argentina e brasileira. Porto Alegre e Buenos Aires. Co-edição Masquatro Editora Ltda e Editorial Café de las Ciudades Ltda. 2013

[8] GARAY, Alfredo Máximo El montaje de una gran intervención urbana (Tradutor, Trans.). In: LUNGO, Mario (Ed.), Grandes proyectos urbanos. San Salvador: UCA Editores, 2004.

[9] HARVEY, David. Do gerenciamento ao empresariamento: a transformação da administração urbana no capitalismo tardio. Espaço e Debates, no 39, p. 48-64, 1996.

[10] LEITE, Carlos. Cidades sustentáveis, cidades inteligentes: desenvolvimento sustentável num planeta urbano. Porto Alegre: Bookman, 2012.

[11] LUNGO, Mario. Grandes Proyectos Urbanos. El Salvador: UCA Editores y Lincoln Institute, 2004.

[12] MARTINEZ, Paulo. Poder e Cidadania. Campinas, SP: Papirus, 1997.

[13] MOULAERT, Frank; RODRIGUEZ, Arantza; SWYNGEDOUW, Erik Achille Marie. The Globalized City: Economic restructuring and social polarization in European cities. Oxford, Oxford University Press, 2003.

[14] OLIVEIRA, Fabrício Leal De et al. Grandes projetos urbanos: o que se pode aprender com a experiência brasileira? Relatório Final. Lincoln Institute of Land Policy. Rio de Janeiro, 2006.

[15] PORTAS, Nuno. El surgimiento del proyecto urbano. Perspectivas Urbanas / Urban Perspectives, n. 3. 2003.

[16] PREFEITURA DE JUIZ DE FORA. Plano Estratégico da Cidade de Juiz de Fora. PlanoJF. Relatório Final. Consórcio Mantenedor, Juiz de Fora, 2000

[17] RIBEIRO, Luiz Cesar de Queiroz. Dos cortiços aos condomínios fechados: as formas de produção da moradia na cidade do Rio de Janeiro. Rio de Janeiro: Civilização Brasileira:IPPUR, UFRJ:FASE, 1997. 
[18] SANDRONI, P. Financiamiento de grandes proyectos urbanos (Tradutor, Trans.). In M. LUNGO (Ed.), Grandes proyectos urbanos (Edição ed., pp. 147-182). San Salvador: UCA Editores, 2004.

[19] SÁNCHEZ, Fernanda. A reinvenção das cidades para um mercado mundial. Chapecó: Argos, 2003.

[20] _ _ Cidade espetáculo: política, planejamento e city marketing. Curitiba: Palavra, 1997.

[21] _. Políticas urbanas em renovação: uma leitura crítica dos modelos emergentes. In: Revista Brasileira de Estudos Urbanos e Regionais. ANPUR, n.1, 115-132. Campinas,1999

[22]

Luciane. As contradições e complementaridades nas leis urbanas de Juiz de Fora: dos planos aos projetos de intervenção. Tese (doutorado). Universidade Federal do Rio de Janeiro, Instituto de Pesquisa e Planejamento Urbano e Regional, 2010.

[23] VAINER, Carlos. Pátria, empresa e mercadoria. Notas sobre a estratégia discursiva do planejamento estratégico urbano. In: ARANTES, Otília; VAINER, Carlos; MARICATO, Ermínia. A cidade do pensamento único. Desmanchando consensos. Petrópolis: Vozes, 2000.

[24] VILLAÇA, Flávio. Dilemas do Plano Diretor. In: O município no século XXI: cenários e perspectivas. São Paulo: Fundação Prefeito Faria Lima-Cepam, 1999. 


\section{Capitulo 3}

\section{A problemática de um sistema de esgotamento sanitário na Ocupação Izidora em Belo Horizonte/MG}

\section{Letícia Helen de Rezende \\ Marcela Soares Souza Vaz Correia \\ Pedro Henrique Fernandes Lage \\ Raquel Sampaio Jacob \\ Tatiane Aparecida Pereira Mendes}

Resumo: 0 saneamento básico é uma ferramenta importante para a garantia da qualidade de vida do ser humano, pois com a oferta de serviços de saneamento adequados é possível mitigar a degradação da qualidade ambiental e assim promover a saúde pública. 0 cenário brasileiro atual mostra que ainda estamos distantes da universalização dos serviços de saneamento em todo o país, principalmente no sistema de esgotamento sanitário, que é crítico em locais que fazem parte de um cenário de exclusão da sociedade, como os assentamentos precários. Assim, este artigo tem como objetivo analisar os principais fatores que contribuem para o desafio de implantação de sistemas de esgotamento sanitário nessas regiões, dada a variedade de problemas que muitas propriedades enfrentam em termos de regularização fundiária, falta de tecnologias adequadas de esgotamento sanitário e conflitos com os órgãos públicos. Este artigo também apresenta um estudo de caso do problema de esgotamento sanitário na Ocupação Izidora, em Belo Horizonte / MG - Brasil, analisando alguns dos fatores que contribuem para o desafio crítico da universalização do acesso aos serviços de saneamento nesta localidade específica. Por fim, este busca demonstrar os indicadores sociais e de saúde críticos que estão diretamente relacionados ao acesso inadequado ou inexistente aos sistemas de esgotamento sanitário, questões que precisam ser atendidas para garantir a qualidade ambiental e o cumprimento dos direitos humanos.

Palavras-Chave: Assentamentos precários, saneamento, direitos humanos, sistema de esgotamento sanitário. 


\section{INTRODUÇÃO}

O saneamento básico é uma importante ferramenta para a promoção da qualidade de vida do ser humano, uma vez que através dos serviços de coleta e tratamento de esgoto, abastecimento de água, manejo correto dos resíduos, e outros serviços essenciais oferecidos à população, é possível mitigar a degradação da qualidade ambiental, eliminando fatores de risco e, assim, promovendo a saúde pública. A percepção de como a qualidade da água consumida e a destinação correta do esgoto sanitário podem causar efeitos nocivos ao homem e ao meio ambiente vem sendo desenvolvida ao longo da história e acredita-se que a promoção da saúde começa pela melhoria do meio ambiente, sendo o investimento em saneamento um agente responsável por esta transformação. (BYDLOWSKI et. al. 2004, apud SOUZA, 2007).

0 atual cenário brasileiro demonstra que o país está distante da universalização dos serviços de saneamento, principalmente em relação ao esgotamento sanitário, ainda que este se configure como direito constitucional assegurado por lei. Segundo o Instituto Trata Brasil (2019), o país tem uma rede de abastecimento de água que pode ser considerada abrangente, o que não se observa na coleta e tratamento de esgoto, que se encontra em situação precária, onde pouco mais da metade dos habitantes tem acesso a esse tipo de serviço, que é agravante em zonas rurais, vilas, ocupações e aglomerados, locais que fazem parte de um cenário excluído da sociedade.

O conceito destas habitações inseridas em situação de exclusão vai de encontro às privações sociais e de infraestrutura encontradas no Brasil e se estende para o crescimento do volume populacional em ocupações, que por si só sofreu grande influência do processo de urbanização do país. A carência e inadequação de políticas de planejamento urbano e habitação das cidades também foram fatores contribuintes para a alocação da população em assentamentos precários nas metrópoles do país e o consequente aumento expressivo do déficit habitacional que se presencia até hoje.

Conscientes da variedade de problemas que essas habitações e regiões enfrentam, os críticos indicadores de saúde que estão relacionados diretamente com o acesso inadequado ou falta de acesso a sistemas de esgotamento sanitário, são preocupações que precisam ser endereçadas. Portanto, o presente estudo objetiva fazer um estudo de caso da problemática do esgotamento sanitário na Ocupação Izidora, em Belo Horizonte/MG, analisando os fatores que contribuem para o crítico desafio da universalização do acesso ao serviço de saneamento neste local.

\section{METODOLOGIA}

\section{1. ÁREA DE ESTUDO}

Como objeto de estudo foi considerada a região da Izidora (Figura 1), localizada no Vetor Norte da cidade de Belo Horizonte/MG - Brasil, na divisa com a cidade de Santa Luzia. Segundo Bizzotto (2015), sua área abrange cerca de $10 \mathrm{~km}^{2}$, sendo $2 \mathrm{~km}^{2}$ pertencentes a uma área de preservação ambiental. Em 2013 esta região foi segmentada em três ocupações urbanas denominadas Rosa Leão, Esperança e Vitória (Bizzotto, 2015), nas quais a topografia é bastante acidentada, variando em sua altimetria de 900 a 675 metros, sendo as maiores altitudes se concentradas nos limites Norte e Sul da região (PBH, 2010).

FIGURA 1. Localização da Região da Izidora e Demarcação das Ocupações.

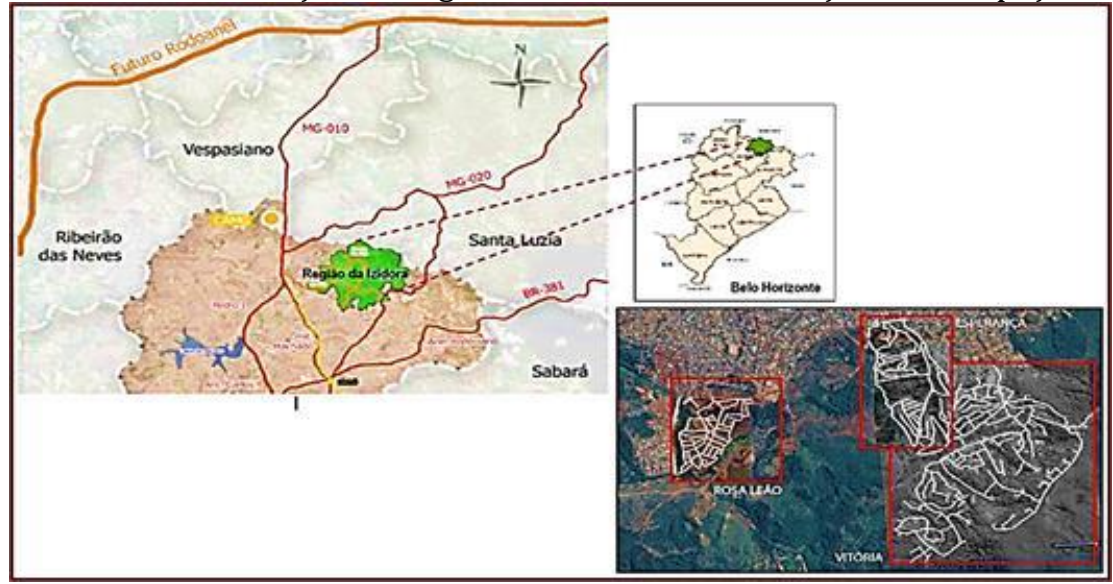


A região pertence a duas unidades de planejamento (UPs), Isidoro Norte e Furquim Werneck, sendo que a primeira possui baixa densidade demográfica e a segunda é marcada pelo segundo pior Índice de Vulnerabilidade Social em Belo Horizonte. Esta unidade possui críticos indicadores de qualidade de vida, e devido a isso, é necessária uma intervenção pública em sua infraestrutura (PBH, 2010).

De acordo com Bizzotto (2015), a Bacia Hidrográfica do Ribeirão Isidoro (Figura 2) é formada por 64 córregos e aproximadamente 280 nascentes, sendo sua área de drenagem correspondente a $55 \mathrm{~km}^{2}$, e os principais córregos da região estudada são: Córrego Terra Vermelha, Córrego dos Macacos, Córrego do Angu e Ribeirão do Isidoro. Em termos ambientais, a região é pertencente à bacia dos Macacos, uma das sub-bacias do rio das Velhas, afluente do Rio São Francisco. Tendo isso como base, qualquer modificação urbana no local deve ser muito bem estudada para não afetar toda a bacia e evitar ao máximo qualquer dano ao rio.

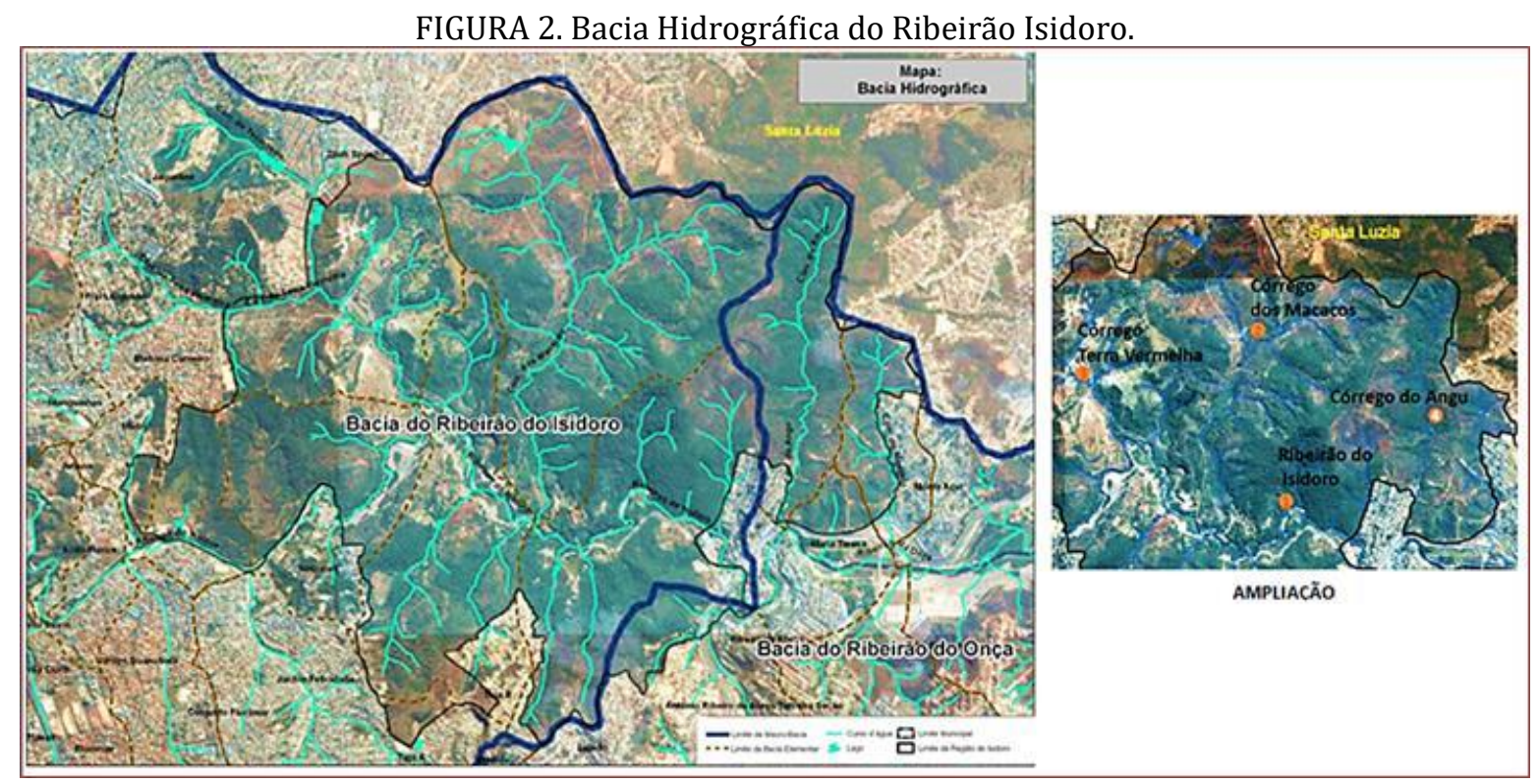

\subsection{LEVANTAMENTO E ANÁLISE DOS DADOS}

A análise dos problemas identificados na Ocupação Izidora foi realizada individualmente de acordo com diagnóstico preliminar realizado pelo Escritório de Integração (EI) do curso de Arquitetura e Urbanismo da Pontifícia Universidade Católica de Minas Gerais e indicadores que refletem diretamente na falta de um sistema de esgotamento sanitário adequado, sendo eles: Índice de Vulnerabilidade Social (IVS) e Índice de Vulnerabilidade de Saúde.

O IVS mede o acesso da população às dimensões ambiental, cultural, econômica, jurídica e de segurança de sobrevivência e seu valor final varia de 0 a 1 . Por ser um índice, seu valor é representado em porcentagem, que expressa um grau de vulnerabilidade de uma população. Quanto maior o seu valor, ou seja, mais próximo de $100 \%$, maior a vulnerabilidade social, e, portanto, mais próxima da exclusão social ela se encontra. Sua leitura é realizada seguindo os seguintes critérios:

0 - 0,2: Muito Baixa; 0,2 - 0,3: Baixa; 0,3 - 0,4: Média; 0,4 - 0,5: Alta; 0,5 - 1,0: Muito Alta.

Os dados são fornecidos pelo Instituto de Pesquisa Econômica Aplicada - Ipea, através do Plano UrbanoAmbiental da Região do Isidoro, da Prefeitura de Belo Horizonte (PBH).

O Índice de Vulnerabilidade da Saúde, segundo a Secretária Municipal de Saúde (2012) é uma associação de variáveis socioeconômicas em um indicador síntese e segue a mesma metodologia de leitura do IVS, sendo medido entre 0 e 1 . Valores mais próximos de 1 refletem uma população muito vulverável em termos de saúde pública, indicando qual área tem prioridade para intervenções e alocações de recursos na área da saúde. Os resultados foram mapeados a partir de pesquisas da Secretaria Municipal de Saúde de 
Belo Horizonte, com base nos dados do CENSO 2010, do Instituto Brasileiro de Geografia e Estatística (IBGE).

O diagnóstico preliminar apresentado pelo EI dispõe as informações referentes à Ocupação Izidora nos aspectos social, econômico e ambiental. O levantamento também fornece as informações históricas da região, conflitos de interesse atuais e posição do poder público frente aos desafios que esta ocupação fornece para o plano diretor da cidade. Dessa forma, a abordagem utilizada para discutir os resultados é qualitativa, sendo o estudo de caso a metodologia de investigação utilizada.

\section{RESULTADOS E DISCUSSÃO}

A partir dos levantamentos de dados realizados sobre a região da Izidora, alguns aspectos críticos foram identificados acerca dos desafios em se implantar um sistema de esgotamento sanitário neste local, discutidos separadamente nos tópicos a seguir.

\subsection{REGULARIZAÇÃO FUNDIÁRIA}

Um fator que contribui para o aumento do contingente populacional em ocupações e intensifica cada vez mais o déficit habitacional - que se estabelece como uma tendência nos países subdesenvolvidos - é a política fundiária. Segundo a PNH (2004), a ausência deste instrumento não só foi responsável pelo aumento especulativo de preços de terrenos urbanos, que isolou a possibilidade de aquisição por parte das menores classes de renda, como também burocratiza o processo de regularização, que muitas vezes não chega nem na última fase em cartório, mesmo cumprindo com os requerimentos da legislação.

Segundo levantamento feito pelo Escritório de Integração do curso de Arquitetura e Urbanismo da Pontifícia Universidade Católica de Minas Gerais, movimentos sociais, quilombolas e trabalhadores possuem conflitos de interesses acerca da propriedade do terreno da região da Izidora, influenciando assim a conciliação e negociação com o poder político, judiciário e empresarial. Esse assunto se relaciona intrinsecamente com a implantação de sistemas de saneamento no local, visto que, a ilegalidade sob a posse de terras serve muita das vezes como pretexto para que as companhias fornecedoras de sistemas de abastecimento de água e esgotamento sanitário não prestem seus serviços.

\subsection{DEMANDA DE TECNOLOGIAS APROPRIADAS}

Outro desafio para implantação de sistemas sanitários em ocupações e demais regiões precárias, é a inadequação de sistemas tradicionais a esses locais. Cairncross e Feachem (1993) através de Gomes (2009) informam que muitas são as implantações inapropriadas e que isso ocorre devido ao emprego de sistemas provindos de países da Europa e América do Norte, sem a preocupação se tais sistemas se adequam aos países com índices de desenvolvimento inferiores.

Nesse contexto, assim como em outros aglomerados subnormais, a Ocupação Izidora não apresenta tecnologias de saneamento adequadas às variáveis que este local impõe a um sistema de esgotamento sanitário convencional. Um destes fatores é a existência de encostas erodidas, fundos de vales (Figura 3) com pré-disposição a riscos geológicos, cortes verticais em taludes, relevo côncavo e convexo (Figura 4), entre outros. Ainda que a população utilize soluções alternativas para contornar a falta de um sistema de saneamento tradicional, muitas vezes, estas alternativas não estão acompanhadas de técnicas adequadas, como é o caso de fossas negras, que intoxicam o solo e a água.

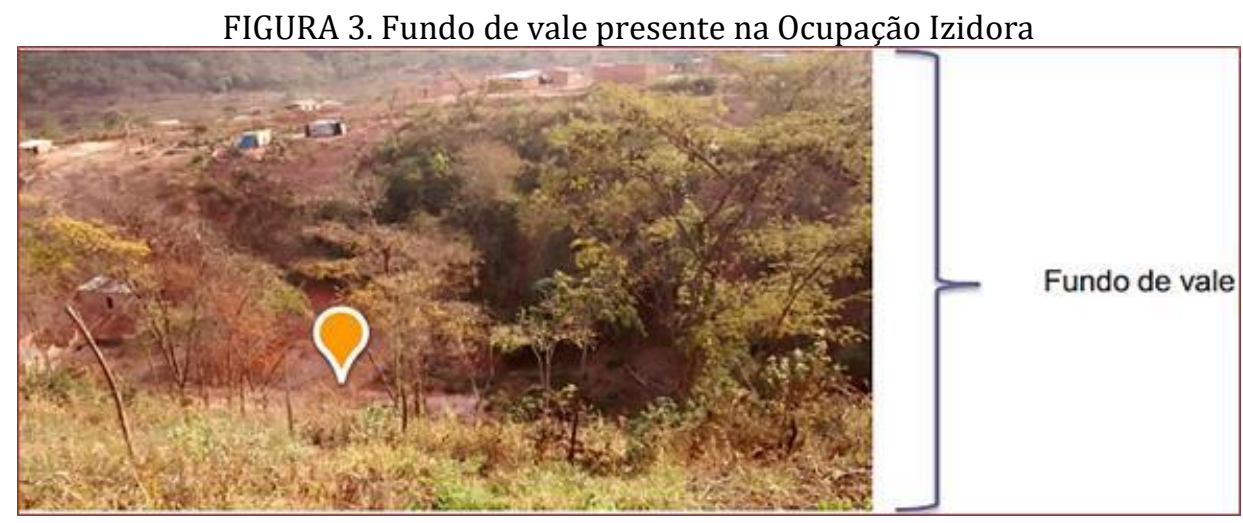


FIGURA 4. Formas do relevo na Ocupação Izidora.

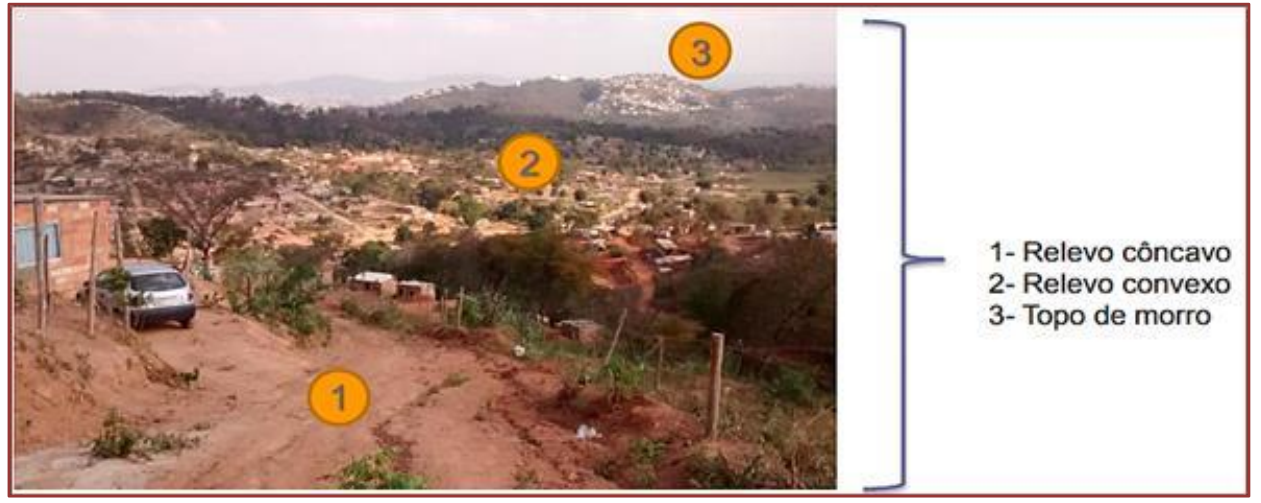

Assim, as opções de tecnologias existentes para o saneamento, como tratamento de esgoto, dependem da eficiência do tratamento, área necessária, complexidade operacional, custo, no qual, a melhor alternativa deverá ser escolhida em função da realidade do local (ABAR, 2019).

\subsection{ATUAÇÃO DO PODER PÚBLICO}

É fundamental que a comunicação entre os poderes executivo, legislativo e judiciário seja eficiente o suficiente para a resolução das demandas apontadas pelos moradores de áreas irregulares. Oliveira (2016) argumenta que não devem ser feitas apenas interferências físicas particulares na região, mas sim um conjunto de ações que busquem o desenvolvimento da relação do governo com as comunidades, fomentando o arranjo com participação social e educação.

Atualmente, a Ocupação Izidora constantemente está em disputa pelo terreno em torno da região do Izidoro, colocando trabalhadores, movimentos sociais e quilombolas em campo oposto ao poder político, judiciário e empresarial. Isto porque a partir da implantação da Cidade Administrativa de Belo Horizonte, da construção da Linha Verde de transporte rodoviário e da transformação do Aeroporto de Confins em terminal industrial, o vetor norte onde o objeto de estudo se localiza passou a ser o novo eixo de desenvolvimento metropolitano de Belo Horizonte e área cobiçada pela especulação imobiliária. Isso apresenta a complexa questão do uso e da destinação deste território, que envolve aspectos sociais, econômicos, políticos, jurídicos, ambientais e fundiários.

Para que esta comunicação aconteça, é necessário que a população residente em áreas precárias se atente para as questões de exclusão social, cidadania, qualidade de vida e a correlação entre esses fatores (SOUZA, 2007). O autor segue mencionando que a orientação adequada da população não tira a responsabilidade do governo de fornecer bens e serviços de qualidade. Tendo em vista a delicada situação em que se encontra o saneamento básico no Brasil, o Estado, como principal responsável pela gestão dos sistemas de saneamento evidencia a lacuna de novos investimentos e continuidade da operação nos sistemas já existentes (GODOY, 2015).

\subsection{INDICADORES SOCIOECONÔMICOS}

Tratando-se do perfil socioeconômico da população que vive na Ocupação Izidora, segundo a PBH (2010), esta possui os índices mais baixos de escolaridade e renda do município. Nesse encadeamento, é relevante levar em consideração o Índice de Vulnerabilidade Social - IVS da Ocupação Izidora e de seu entorno.

Considerando o contexto acima, a (Tabela 1) expõe o IVS de algumas Unidades de Planejamento de Belo Horizonte. Por meio de sua análise, verifica-se que a população das UPs Isidoro Norte e Furquim Werneck, que fazem parte a Ocupação Izidora, encontram-se em situação de exclusão social, sendo que a Furquim Werneck apresenta um dos mais altos índices de vulnerabilidade social inscritos no Município $(0,78)$, sendo superada apenas pela região da Barragem Santa Lúcia, que é marcada pela favelização e violência urbana com índice de 0,79 (PBH,2010). 
TABELA 1. Classificação de UP’s de acordo com o IVS.

\begin{tabular}{|c|c|}
\hline UP & IVS \\
\hline Barragem Santa Lúcia & 0,79 \\
\hline Furquim Werneck & 0,78 \\
\hline Jardim Felicidade & 0,78 \\
\hline Cafezal & 0,76 \\
\hline Ouro Preto & 0,52 \\
\hline Buritis & 0,48 \\
\hline Savassi & 0,12 \\
\hline
\end{tabular}

Ainda que os demais dados apresentados sejam diferentes em relação às unidades de Planejamento Isidoro Norte e Furquim Werneck, pode-se notar que os bairros que fazem fronteira com a região do Izidora, em sua maioria, enfrentam problemas semelhantes aos das UPs analisadas, além de serem ocupações relativamente recentes se comparadas aos bairros urbanizados da cidade.

\subsection{INDICADORES DE SAÚDE}

Por fim, analisando o Índice de Vulnerabilidade da Saúde, com dados do Censo 2010, a Secretária Municipal de Saúde (2012) relata que a Granja Werneck, onde a Ocupação Izidora está localizada, apresenta um índice muito elevado, da ordem de $86 \%$, estando entre os piores índices de Belo Horizonte/MG, conforme demonstrado na (Figura 5). Dado que o indicador está diretamente relacionado à existência, ou não, de um sistema de saneamento adequado, pois este interfere na promoção da saúde, este resultado explicita a necessidade de melhorias estruturais profundas nas soluções de saneamento básico no local visando a melhoria da qualidade ambiental e a garantia e consolidação desse direito constitucional.

FIGURA 5. Índice de Vulnerabilidade da Saúde por Bairros do Município de Belo Horizonte.

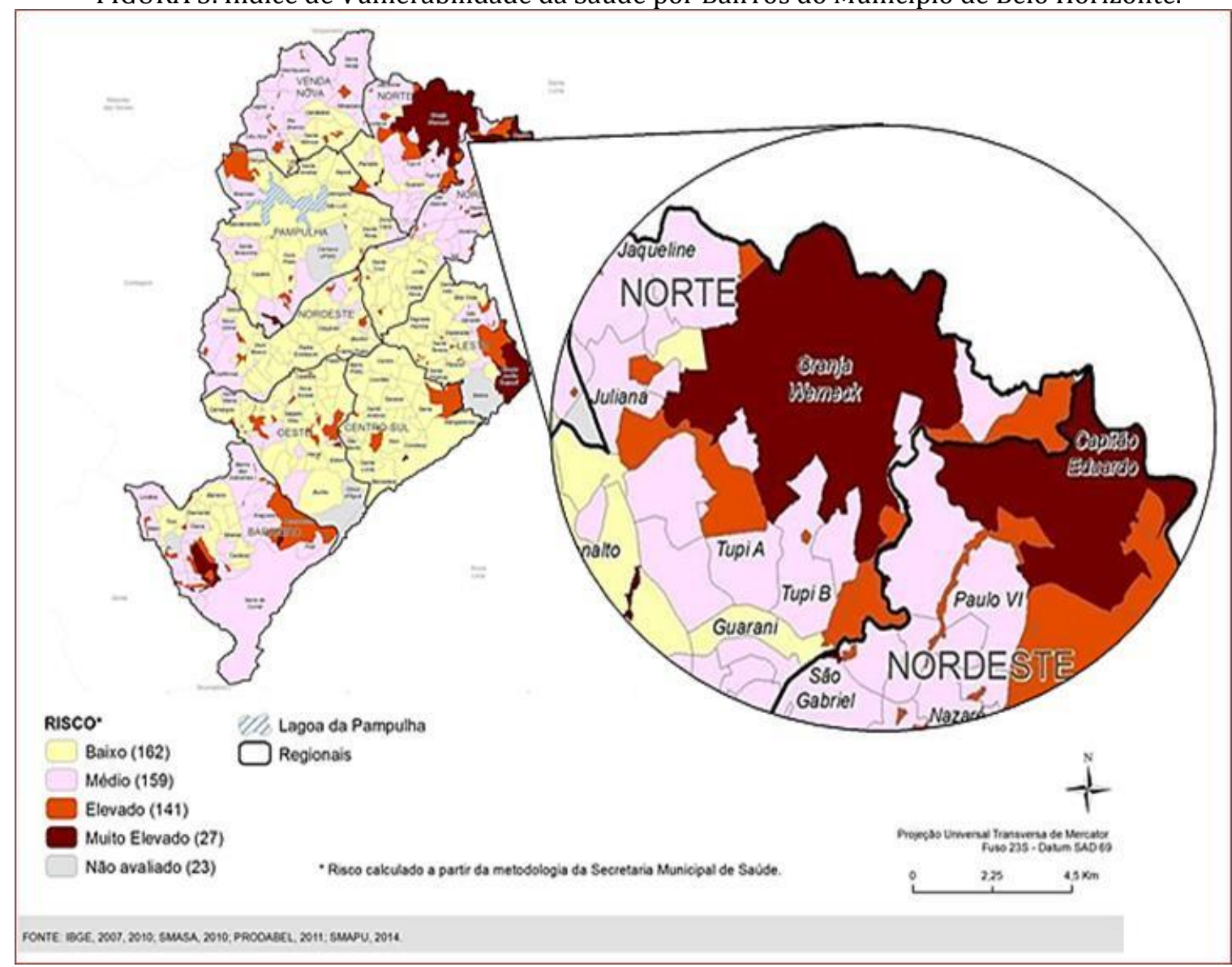

\section{CONCLUSÃO}

A partir da análise apresentada, demonstra-se uma clara necessidade da expansão de soluções de saneamento para ocupações, permitindo maior abrangência e inserção das comunidades exclusas pelo 
poder publico, promovendo a consolidação do direito universal de acesso ao saneamento básico e, consequentemente, melhorando os indicadores sociais, ambientais e econômicos nos campos de educação, trabalho, economia, biodiversidade, disponibilidade hídrica, entre outros. Ocupações possuem características muito individuais e específicas que dificilmente estão presentes em locais com um plano de urbanização dentro dos parâmetros da engenharia, demonstrando ainda a necessidade do diálogo contínuo dos órgãos públicos com a comunidade local.

A conexão entre saúde e saneamento não somente possui relação direta entre si, como também quando analisadas em conjunto impactam de forma mais intrínseca o desenvolvimento da sociedade. Sendo assim, é importante investir em sistemas eficientes de saneamento, para que haja aumento homogêneo na qualidade de vida da população e também crescimento econômico do país. A adoção de medidas pontuais de saneamento e outras obras em locais precários são importantes, e deve-se promover a ação integrada de diversos setores e a conscientização e colaboração por parte dos usuários, moradores, indústrias e demais envolvidos.

\section{REFERÊNCIAS}

[1] ABAR. Desafios e soluções para a universalização do esgotamento sanitário no Brasil. Sumário executivo. 2019. 58f. Disponível em: <file:///C:/Users/ferr-

/AppData/Local/Packages/Microsoft.MicrosoftEdge_8wekyb3d8bbwe/TempState/Downloads/Desafios\%20e\%20Sol

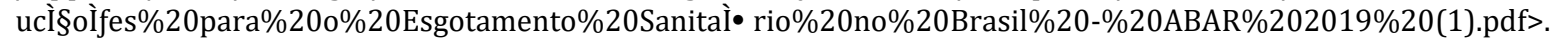
Acesso em: 14 out. 2019.

[2] BIZZOTTO, Luciana Maciel. \#RESISTEIZIDORA: controvérsias do movimento de resistência das Ocupações da Izidora e apontamentos para a justiça urbana. Orientador: Profa. Dra. Jupira Gomes de Mendonça. 2015. 241 p. Dissertação (Pós-graduação em Arquitetura e Urbanismo da Universidade) - Universidade Federal de Minas Gerais, Belo Horizonte, 2015. Disponível em: <http://blog.indisciplinar.com/wpcontent/uploads/2015/10/Disserta\%C3\%A7\%C3\%A3o-ResisteIzidora-Luciana-Bizzotto.pdf>. Acesso em: 13 ago. 2019.

[3] BRASIL. Plano Nacional De Habitação. (Dezembro de 2009). Disponível em: <http://www.urbanismo.mppr.mp.br/arquivos/File/Habitacao/Material_de_Apoio/PLANONACIONALDEHABITAO.pd f>. Acesso em: 13 ago. 2019.

[4] BRASIL. Política Nacional De Habitação. (Novembro de 2004). Disponível em: <http://www.cidades.gov.br/images/stories/ArquivosSNH/ArquivosPDF/4PoliticaNacionalHabitacao.pdf>. Acesso em: 13 ago. 2019.

[5] GOMES, Uende Aparecida Figueiredo. Intervenções de saneamento básico em áreas de vilas e favelas: um estudo comparativo de duas experiências na região metropolitana de Belo Horizonte. 2009. 177f. Dissertação (Programa de Pós-Graduação em Saneamento, Meio Ambiente e Recursos Hídricos) - Escola de Engenharia, Universidade Federal de Minas Gerais, Belo Horizonte, 2009. Disponível em: <https://repositorio.ufmg.br/handle/1843/BUDB-8AVNAQ>. Acesso em: 12 out. 2019.

[6] QUADROS, Débora et al. O AMBIENTE TECNOGÊNICO RESULTANTE DA INTERAÇÃO ANTRÓPICA E MEIO FÍSICO: Diagnóstico físico-ambiental da unidade hidrográfica em meio urbano e os impactos da urbanização.2018. Trabalho Impresso (Graduação em Arquitetura e Urbanismo da Universidade) - Belo Horizonte: Pontifícia Universidade Católica de Minas Gerais - PUC/MG.

[7] INSTITUTO TRATA BRASIL. Ranking do Saneamento, 2019. Disponível em: < http://www.tratabrasil.org.br/images/estudos/itb/ranking2019/PRESS_RELEASE__Ranking_do_Saneamento__NOVO.pdf>. Acesso em: 13 out. 2019

[8] PREFEITURA DE BELO HORIZONTE (PBH). Plano Urbano Ambiental da Região do Isidoro. 2010. Disponível em: <https://prefeitura.pbh.gov.br/sites/default/files/estrutura-de-governo/politica-urbana/2018/planejamentourbano/ouc_plano_urbano_ambiental_isidoro.pdf>. Acesso em: 02 set. 2019.

[9] SECRETÁRIA MUNICIPAL DE SAÚDE. Índice de Vulnerabilidade de Saúde. Belo Horizonte, 2012. Disponível em: https://prefeitura.pbh.gov.br/sites/default/files/estrutura-de-governo/saude/2018/publicacaoes-da-vigilanciaem-saude/indice_vulnerabilidade2012.pdf. Acesso em: 7 mar. 2020.

[10] SOUZA, Cezarina Maria Nobre. Relação Saneamento-Saúde-Ambiente: os discursos preventivista e da promoção da saúde. Saúde Soc., São Paulo, v. 16, n. 3, p. 127-137, 1 jan. 2007. Disponível em: <https://www.scielosp.org/pdf/sausoc/2007.v16n3/125-137/pt>. Acesso em: 5 set. 2019. 


\section{Capítulo 4}

Modelagem de rotograma para mitigação dos riscos associados ao transporte de cargas perigosas Nitrato de Amônio pela SP 160 - Rodovia dos Imigrantes

Anna Julia Renzo Aguayo

Resumo : A discussão sobre segurança, nos processos da Cadeia de Suprimentos para cargas especiais tomou força no ano de 2020, devido à explosão em Beirute (Líbano), durante o período de armazenagem do Nitrato de Amônio. No Brasil, as ocorrências de acidentes com cargas especiais acontecem predominantemente, durante o transporte. 0 presente artigo tem por objetivo apresentar a "Rotograma para Mitigação de Riscos Associados ao Transporte de Cargas Perigosas - Nitrato de Amônio" no sentido Norte da SP 160 - Rodovia dos Imigrantes. A partir dos levantamentos e análises realizados, foram propostas medidas básicas de gerenciamento de risco para pontos e segmentos com riscos significantes. Assim, a vulnerabilidade do traçado ascendente da Imigrantes está relacionada à presença de corpos hídricos, sobretudo nos cruzamentos com braços e remansos da represa Billings, nos mananciais da Baixada Santista e nos ambientes sensíveis da Serra do Mar. Outro aspecto relevante é o grande risco de acidente e vulnerabilidade ambiental, na presença de OAEs - Obras de Arte Especiais, em função das intersecções na Rodovia, principalmente na Planície Litorânea.

Palavras-Chave: Nitrato de Amônia. Transporte. Carga Perigosa. 


\section{INTRODUÇÃO}

Os fertilizantes à base de nitrato de amônio são considerados produtos perigosos e importantes insumos para a cadeia logística do agronegócio, no Brasil e no mundo, possibilitando o aumento da produção de alimentos e energia, com um pequeno acréscimo de áreas agricultáveis. Nesse contexto, o Brasil se destaca por ser um grande exportador de commodities agrícolas, possuir áreas para expansão de sua fronteira agrícola e condições naturais favoráveis para o desenvolvimento de uma agricultura intensiva e, embora o país apresente características que lhe conferem vantagens competitivas, existem dificuldades atreladas à produção, cada vez mais interiorizada e aos gargalos no escoamento da produção até as regiões portuárias (OLIVEIRA, 2013).

Além disso, os desafios logísticos associados ao produto impactam na esfera econômica e ambiental, que requer uma infraestrutura de armazenagem e de transporte eficiente, visando atender aos requisitos ambientais para acesso às matérias-primas e à viabilidade do escoamento produtivo. Os acidentes envolvendo a armazenagem e o transporte de produtos perigosos colocam em risco a segurança da população e o meio ambiente devido às propriedades físico químicas presentes nos materiais, como inflamabilidade, toxicidade, corrosividade, patogenicidade, radioatividade, entre outros (OLIVEIRA, 2013).

Como visto, a armazenagem e o transporte de nitrato de amônio, tanto na forma de explosivos, como na de fertilizantes representa um desafio que precisa ser gerido, para mitigar possíveis impactos resultantes de acidentes com a sua operação.

Segundo Oliveira (2013), no cenário mundial a maior parte dos acidentes com produtos perigosos ocorrem em instalações fixas (armazenagem), com uma predominância de 54\%. No Brasil, verifica-se que apenas $15 \%$ dos acidentes ocorreram nesse tipo de instalação e $70 \%$, durante o seu transporte e operações de carga e descarga. Ademais ressalta-se que, o modal rodoviário é segundo a CETESB Companhia Ambiental do Estado de São Paulo (2020) responsável por 37,4\% dos casos de acidentes com produtos perigosos, no estado de São Paulo, em razão de ser este um grande centro produtor e consumidor.

Desse modo, a prevalência de acidentes com produtos perigosos relacionados ao modal de transporte rodoviário torna relevante o estudo acerca dos procedimentos e tecnologias capazes de prevenir ou mitigar impactos ambientais adversos.

Tendo isso posto, a pesquisa científica é um estudo que visa responder questões mediante a aplicação do método científico. Tem como características a discussão de ideias e fatos relevantes sobre determinado assunto que seja reconhecível e claro, de utilidade para a ciência ou comunidade, demonstrando domínio do assunto, por parte do autor, dizendo algo que ainda não foi dito, indicando com clareza os procedimentos utilizados, fornecendo elementos que permitam verificar suas conclusões, documentando os dados fornecidos, organizando a comunicação, de modo lógico e com redação correta, agradável e clara. (PRODANOV, 2013)

Os métodos utilizados nesta pesquisa foram a revisão bibliográfica, análise quantitativa e análise qualitativa. A revisão bibliográfica é, em determinada área temática, dentro de um recorte de tempo, um estudo que analisa a produção bibliográfica, fornecendo uma visão geral ou um relatório sobre um tópico específico (NORONHA E FERREIRA, 2000). A análise quantitativa classifica e analisa informações após traduzi-las em números, considerando assim que tudo pode ser quantificável. Já a pesquisa qualitativa considera que há um vínculo entre o mundo objetivo e a subjetividade do sujeito que não pode ser traduzido em números, sendo esta análise descritiva e seus dados são analisados indutivamente (PRODANOV, 2013).

É objetivo geral deste estudo mapear a rota de transporte de produtos perigosos, com foco em Fertilizante Nitrato de Amônio, no trecho Norte da Rodovia dos Imigrantes (SP - 160), através da sistematização de dados primários e secundários, cujo produto final é a elaboração de um Mapa Geral de Rota - Rotograma, uma ferramenta de inteligência espacial que permite o sequenciamento do trajeto da carga e os potenciais riscos envolvidos, visando a diminuição e mitigação de acidentes nas rodovias.

Ademais, são objetivos específicos deste estudo a compreensão dos aspectos gerais relacionados à gestão eficiente do Transporte Rodoviário de Produtos Perigosos (TRPP), incluindo os atributos fundamentais das Fichas de Informação de Produto Químico - FISPQ, a elaboração de um histórico, com os principais acidentes ocorridos com nitrato de amônio, no país e a sistematização acerca da legislação e normas aplicáveis ao caso. 


\section{FUNDAMENTAÇÃO TEÓRICA}

O Gerenciamento da Cadeia de Suprimentos é a integração dos processos de negócios desde o usuário final até os fornecedores primários que providenciam produtos, serviços e informações. É realizado com o intuito de adicionar valor para os clientes e stakeholders de uma empresa (Global Supply Chain Forum, citado por Pires, 2004).

Segundo Pedro Duran (2020), o Brasil importa nitrato de amônio de países como Rússia e Emirados Árabes através de navios que podem carregar até 30 mil toneladas do produto. 0 porto de Paranaguá é a principal porta de entrada dos fertilizantes, no Brasil. Após a chegada nos portos brasileiros, o transporte a diversos estados brasileiros se dá por caminhões do tipo Bitrem, com capacidade aproximada de 40 toneladas.

O nitrato de amônio deve ser armazenado com cuidado em lugar seco, fresco e arejado, protegido das intempéries, longe de produtos inflamáveis e de possíveis faíscas. Também deve-se evitar seu armazenamento em conjunto com produtos não fertilizantes (GUARÇONI, 2020).

De acordo com o IBGE (2015), os estados brasileiros que mais consumiram fertilizantes nitrogenados em 2014 foram SP, MG, RS, MT, PR, GO, BA e MS, nesta ordem. Esta demanda é explicada pelo cultivo de diversos produtos, sendo os principais: soja, milho, cana-de-açúcar e café.

0 nitrato de amônio geralmente é fornecido sob forma perolada ou granulada. Para que sua qualidade seja mantida até seu uso, de acordo com a ANDA (2018), é preciso que esteja isento de umidade e empedramento, livre de contaminações e mínimo conteúdo de pó. Para prevenção contra umidade e empedramento, pode ser requerido que o material seja coberto com mantas de plástico durante o transporte ou armazenamento e que os prédios de armazenagem sejam mantidos o mais fechados possível para não haver a entrada de umidade e ar. Para prevenir a contaminação é necessária a limpeza dos locais de armazenagem antes da chegada do produto e das áreas de acesso durante a armazenagem. Para evitar a fragmentação do conteúdo, o produto não deve ser exposto diretamente aos raios solares ou em condições de grandes variações de temperatura.

Ainda de acordo com a ANDA (2018), fertilizantes à base de nitrato de amônio podem ser armazenados, manipulados e transportados embalados ou a granel. Na armazenagem, manipulação e transporte do produto embalado, a contaminação inadvertida é evitada, enquanto no granel há perigo maior de contaminação inadvertida do produto. No entanto, no granel é difícil que haja a penetração do fogo e de calor no caso de incêndio, mas se o produto está embalado permite-se a penetração mais facilitada de calor e do fogo entre os sacos e os pallets.

Se faz necessário que as pessoas que possuem contato direto ou indireto no transporte, armazenagem ou manuseio do NA possuam conhecimentos gerais e específicos para evitarem sinistros. Os conhecimentos gerais incluem simbologia, rotulagem, normas de segurança genéricas, utilização de EPI's - Equipamento de Proteção Individual, em situações normais de carregamento, transporte, manuseio, armazenamento e estocagem de produtos. As situações particulares do produto requerem instrução, treinamento em caso de vazamentos e/ou derrames, aliado ao correto uso de EPI's e ao pronto atendimento dos procedimentos de segurança, no momento do sinistro.

Ballou (2006) destaca, a importância da unitização de cargas. Ao passo que aumenta o tamanho da carga, se torna menor o número de viagens necessárias para estocar uma determinada quantidade de mercadorias havendo maior economia de custos. Logo, se há uma consolidação de volumes menores numa única carga, a eficiência é melhorada. Isto é a unitização de cargas, sendo mais comumente feito por meio da paletização e conteinerização.

Dentro da classificação acima, existem cargas que devido suas características físico-químicas, necessitam de tratamento, normas e embalagens diferenciadas. São elas cargas vivas, frigoríficas e perigosas, as cargas especiais.

Carga especial é a carga que demanda cuidados específicos no carregamento, transporte e armazenamento em virtude de seu peso, natureza e/ou dimensões, Spigolon (2010). Devido à sua natureza, o Nitrato de Amônio (NA) é considerado uma carga especial por ser uma substância perigosa, pois sob algumas circunstâncias pode se decompor em água, nitrogênio e oxigênio, produzindo uma série de gases que, aquecidos durante sua decomposição se ampliam rapidamente e explodem, podendo causar mortes e danos materiais. Se vazado, o NA também pode causar a poluição do solo, água, ar e biota.

Ao categorizarmos os acidentes com substâncias perigosas ao longo da Cadeia de Suprimentos, podemos dividi-los em dois grupos principais: acidentes em instalações fixas e acidentes em transportes. Vê-se na 
Figura 1 que no panorama internacional ocorrem mais acidentes em instalações fixas enquanto, no Brasil ocorrem mais acidentes em transportes:

Figura 1 - Proposta Metodológica Cenário Internacional × Cenário Nacional: Instalações Fixas e Transporte

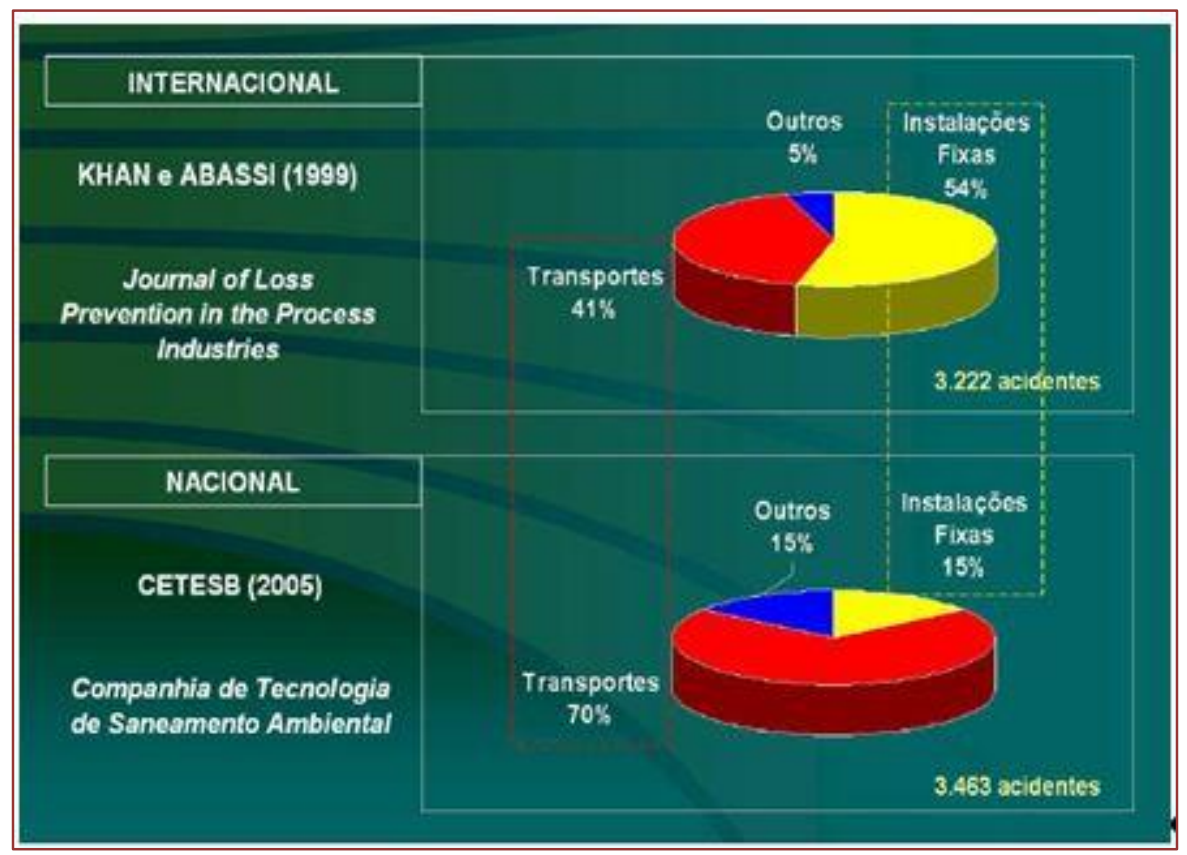

Fonte: Cunha (2009, p. 36)

Cunha (2009) também apresenta que 84\% dos acidentes de substâncias perigosas em transporte no Brasil ocorrem no modal rodoviário, contra 8\% no marítimo, 6\% no dutoviário e 2\% no ferroviário.

Em agosto de 2020 ocorreu uma explosão no Porto de Beirute, no Líbano, deixando 3,7 mil feridos e 100 mortos gerando uma onda sísmica equivalente a um terremoto de 3,3 de magnitude. A principal suspeita é de que um armazém com aproximadamente 2.700 toneladas de nitrato de amônio armazenadas de maneira irregular provocou o acidente (Vitorio, 2020).

0 desconhecimento de como agir perante um acidente envolvendo Nitrato de Amônio pode acarretar consequências de altas proporções. Em 2004, em Bucareste - Romênia, um caminhão que transportava NA tombou, e por apagarem o incêndio ocorrido logo após o acidente, houve uma explosão que formou uma cratera de 40 metros de largura e 10 metros de profundidade e deixou 18 vítimas fatais.

A Figura 2 apresenta a lista de alguns dos acidentes no modal rodoviário com NA, usado como explosivo intermediário para detonantes no Estado de São Paulo:

Figura 2 - Acidentes com NA no Modal Rodoviário no Estado de São Paulo

\begin{tabular}{|c|c|c|c|c|c|}
\hline Ano & Municipio & Rodovia & Causa & Quantidade Vazada & $\begin{array}{c}\text { Meios } \\
\text { Atingidos }\end{array}$ \\
\hline 2010 & Lorena & Dutra, Pres. & Colisão/Choque & 200 Litros & Flora \\
\hline 2011 & Itu & Archimedes Lammooglia,Dep. & Bomba & Não estimado & Solo \\
\hline 2016 & Capão Bonito & Francisco da Silva Pontes, Prof. & Tombamento & 10 Toneladas & Solo \\
\hline 2017 & Guaratinguetá & Dutra, Pres. & Tombamento & 100 Quiligrama(s) & Não Houve \\
\hline 2020 & Miracatu & Regis Bittencourt & Outra & 500 Quilograma(s) & Solo \\
\hline
\end{tabular}

Fonte: Adaptado de CETESB (2020) 
Observa-se que na maioria dos casos o meio ambiente foi atingido e que as causas dos acidentes foram diversas. De acordo com Poffo, Gouveia e Haddad (2005), a comunicação de riscos é um mecanismo importante para que o atendimento aos acidentes ambientais seja adequado e para que os prejuízos à saúde da população e ao meio ambiente sejam minimizados.

Utilizada nos atendimentos aos acidentes, a Ficha de Segurança Produto Químico (FISPQ) serve para comunicar os perigos relacionados aos produtos químicos, e é um documento elaborado pelo fabricante do produto. De acordo com Oliveira (2013), é necessário que as FISPQ sejam validadas por órgãos de competência no âmbito federal, pois verificou-se que as FISPQ para Nitrato de amônio (fertilizante) de diferentes empresas apresentam informações conflitantes. Oliveira (2013) sugeriu informações para a padronização da FISPQ de acordo com os riscos de manuseio, armazenagem e transporte do produto. 0 texto abaixo e as figuras 3 e 4 contemplam as sugestões para transporte:

\subsection{REGULAMENTAÇÕES NACIONAIS E INTERNACIONAIS:}

- $\quad$ Terrestre: Decreto Federal no 96.044 de 18/05/88 - Aprova o Regulamento para o Transporte Rodoviário de Produtos Perigosos.

- Hidroviário: IMDG - International Maritime Dangerous Goods Code.

- $\quad$ Aéreo: ICAO-TI / IATA-DGR.

Regulamentações adicionais:

- $\quad$ Nome apropriado para embarque: Nitrato de Amônio (NH4NO3).

- Classe de risco: 5.1 - Substância Oxidante.

Figura 3 - Sugestão de Rótulo de Risco e Placa de identificação do produto para a tabela FISQP - produto NA

\begin{tabular}{|l|l|}
\hline 50 & $\begin{array}{l}\text { ROTULODERISCO } \\
\text { Subclasse 5.1 } \\
\text { Substâncias oxidantes } \\
\text { Símbolo (chama sobre um circulo): preto. } \\
\text { Fundo: amarelo } \\
\text { Número "5.1" no canto inferior. }\end{array}$ \\
\hline 2067 & $\begin{array}{l}\text { Placa de identificaçäo do produto. } \\
50=\text { material oxidante que intensifica o fogo } \\
2067=\text { número ONU }\end{array}$ \\
\hline
\end{tabular}

Fonte: Oliveira (2013, p 103)

- Número de risco: 50

- $\quad$ Número ONU: 2067

- Grupo de embalagem: III - Substância que apresentam baixo risco.

- Sinalização no caminhão: Transporte do NA 
Figura 4 - Sugestão de Sinalização no caminhão para a tabela FISQP - produto NA

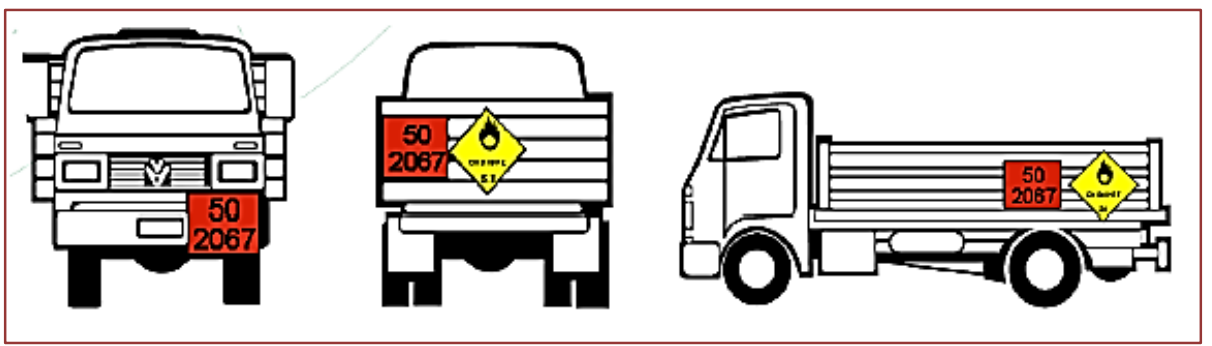

Fonte: Oliveira (2013, p 103)

\section{PROCEDIMENTOS METODOLÓGICOS}

A Rodovia dos Imigrantes - SP 160 é um empreendimento que constitui um dos maiores corredores de exportação do país e tem grande importância para a economia brasileira, interligando a Região Metropolitana de São Paulo com o porto de Santos, o polo petroquímico de Cubatão, as indústrias do ABCD e a Baixada Santista, com um movimento anual superior a 30 milhões de veículos.

Seu projeto inaugural data de 1976, quando foi construída a pista Norte (ascendente), sendo refeita, em relação ao projeto original, em 1986. Posteriormente, em 2002 foi inaugurada a Pista Sul (descendente). A rodovia faz parte do Sistema conhecido como Anchieta-Imigrantes - SAI, do qual fazem parte, ainda a Rodovia Cônego Domênico Rangoni (SP 248-55) e a Rodovia Padre Manuel da Nóbrega (SP 055), sendo administrada, desde 1998 pela empresa concessionária Ecovias dos Imigrantes (DERSA, 2020).

Devido às dificuldades de transposição da Serra do Mar, a rodovia é considerada um dos maiores e mais emblemáticos projetos de engenharia da modernidade, sendo um marco na história do desenvolvimento urbano do país, além de constituir um avanço social, logístico e econômico.

Assim, o Porto de Santos é considerado o principal do Brasil e o maior da América Latina. Segundo dados da Santos Port Authority (2020), em 2011 foram movimentadas no Porto de Santos 97,2 milhões de toneladas de cargas e em 2019, 134 milhões, representando um aumento expressivo, de 38,2\% de movimentação nesse período, impulsionado principalmente pelas exportações realizadas.

As principais características da Rodovia dos Imigrantes estão apresentadas a seguir:

- $\quad$ Extensão total: $58,54 \mathrm{~km}$;

- $\quad$ Extensão do trecho analisado: $40 \mathrm{~km}$;

- $\quad$ Número de pistas: 2;

- Faixas pista ascendente: 4 Trecho planalto, 3 Trecho túnel e 3 Trecho Litorâneo.

- Viadutos: 44;

- Pontes: 7;

- Trevos: 7;

- Túneis: 14;

- Túneis Subida: 11 ;

- Municípios: Praia Grande, São Vicente, Cubatão, São Bernardo do Campo, Diadema e São Paulo.

- Velocidade diretriz: $110 \mathrm{~km} / \mathrm{h}$;

- Volume médio diário (VDM): 34.895 (2018). 
O presente estudo tem por objetivo apresentar o "Rotograma para Mitigação de Riscos Associados ao Transporte de Cargas Perigosas - Nitrato de Amônia", no trecho compreendido entre os quilômetros 35 a 74, da Rodovia dos Imigrantes, no sentido Norte (trecho ascendente), de forma que seus trechos possam ser avaliados de forma adequada, com a finalidade de definir medidas básicas para o gerenciamento dos riscos impostos durante o transporte de produtos perigosos, com foco em nitrato de amônio.

Para sua realização foi necessária a elaboração de um banco de dados, através de um Sistema de Informações Geográficas (SIG), utilizando o software de geoprocessamento Quantum Gis e as ferramentas de imagens disponibilizadas pelo programa de computador Google Earth Pro, cuja finalidade é a geração de mapas que auxiliem a tomada de decisão por parte do gestor/operador de transporte, para conhecer detalhes sobre a rota, como trechos críticos e vulneráveis, além do mapeamento de riscos que possam acarretar em acidentes na rodovia.

Desse modo, as bases de dados consultadas para consolidar as informações cartográficas, tabelas e quadros foram retiradas de portais da internet como: DataGeo - Infraestrutura de Dados Espaciais Ambientais do Estado de São Paulo, DnitGeo - Departamento Nacional de Infraestrutura de Transportes, Mapas e Bases dos Modos de Transporte, do Ministério dos Transportes, MMA - Ministério do Meio Ambiente, estatísticas da CETESB, entre outros.

Ademais, para alcançar o objetivo foram realizadas adaptações provenientes de materiais técnicos, como Manual para Implementação de Emergência Para Atendimento a Sinistros Envolvendo o Transporte Rodoviário de Produtos Perigoso (DNIT, 2005) e metodologias consagradas da área, provenientes de outros órgãos, dissertações de mestrado, entre outros.

Assim, em um primeiro momento, a metodologia aplicada para elaboração do Rotograma contou com o levantamento dos principais aspectos funcionais, operacionais e de infraestrutura da rodovia, utilizando o Software de imageamento Google Earth Pro. É necessário destacar que devido às funcionalidades deste programa, a etapa de realização de trabalho de campo, não foi necessária, pelo nível de detalhamento conferido pelas imagens, atendendo assim a demanda do projeto.

Em seguida, utilizou-se o software Quantum Gis para o cruzamento dos pontos levantados, na fase anterior, com as demais bases de dados obtidas. Além disso, nesta etapa também foi realizado um processamento de dados para obter a localização dos quilômetros de referência, na rodovia. Ressalta-se que este procedimento foi importante para a delimitação dos trechos de análise da rodovia, avaliação dos pontos críticos e para a organização do banco de dados da rodovia.

Desse modo, os principais indicadores levantados nos trechos se relacionam à Infraestrutura de Apoio Viário e de Concessão, Meio Antrópico, Meio Biótico e Meio Físico, além de dados de interesse, sobre a área de influência indireta do empreendimento.

\section{RESULTADOS E DISCUSSÃO}

O Quadro 1, a seguir possui as principais categorias e tipologias associadas, identificadas ao longo da rodovia, que possuem especial interesse para o transporte rodoviário de produtos perigosos.

Quadro 1 - Principais Categorias e Tipologias Identificadas ao longo do Trecho da Rodovia dos Imigrantes.

\begin{tabular}{|l|l|}
\hline \multicolumn{1}{|c|}{ Categoria } & \multicolumn{1}{c|}{ Tipologia } \\
\hline Infraestrutura Viária & $\begin{array}{l}\text { Posto da Polícia Rodoviária, Balança de pesagem, Estacionamentos, Passarelas e } \\
\text { travessias, Praças de Pedágio, Postos de Serviços, Restaurantes, Hotéis, Áreas de Lazer, } \\
\text { Hospitais, entre outros. }\end{array}$ \\
\hline Meio Socioeconômico & $\begin{array}{l}\text { Uso e Ocupação do Solo, Comércio, Vendedores Ocupando a Faixa de Domínio, } \\
\text { Comunidades Indígenas, Escolas, rodoviárias, entre outros. }\end{array}$ \\
\hline Meio Físico & $\begin{array}{l}\text { Identificação de rios, lagos e lagunas. Trechos submetidos a frequentes fenômenos } \\
\text { climáticos, queimadas sazonais, entre outros. }\end{array}$ \\
\hline Meio Biótico & $\begin{array}{l}\text { Identificação de Unidades de Conservação (UCs), fauna existente e em extinção, entre } \\
\text { outros. }\end{array}$ \\
\hline $\begin{array}{l}\text { Área de Influência } \\
\text { Indireta }\end{array}$ & Principais acidentes ocorridos, dados municipais, decretos, entre outros. \\
\hline
\end{tabular}


O TRPP envolve muitos fatores e operações, sendo a principal causa que pode levar a um acidente, a direção do veículo. Entretanto, os equipamentos envolvidos (veículo e acessórios) e outros fatores (condições climáticas, tipo e condições da via), também podem influenciar sua ocorrência. Dessa forma, os principais perigos associados a esse tipo de transporte podem ser divididos em:

- Erros humanos (direção perigosa, cansaço, rota, estiva inadequada, contaminação do produto, entre outros);

- Falha de Equipamentos (defeito material, corrosão de equipamentos, falha de embalagens, entre outros),

- Falhas de Sistemas ou Procedimentos (treinamento, manutenção, seleção de rota, entre outros);

- E eventos Externos (acidentes, deslizamentos de terra, condições climáticas adversas, entre outros).

Ainda, vale destacar que no Brasil existem sistemas específicos voltados para a melhoria e qualidade do TRPP, desenvolvido por instituições que trabalham com o gerenciamento desse tipo de atividade, como o SASSMAQ - Sistema de Avaliação de Segurança, Saúde, Meio Ambiente e Qualidade, da ABIQUIM, um programa de avaliação de sistemas de gestão ambiental, de saúde, da segurança e da qualidade voltado para os prestadores de serviço logístico, responsáveis pelo transporte de produtos químicos (ABIQUIM, 2020).

\subsection{ANÁLISE HISTÓRICA DE ACIDENTES}

O DNER (1999) - Departamento Nacional de Estradas de Rodagem, atualmente representado pelo DNIT, enquadra a Rodovia dos Imigrantes (em ambas os sentidos) na Classe Funcional 0 - Via Expressa, correspondente ao padrão máximo de eficiência em infraestrutura rodoviária, com controle total de acessos e baixa ocorrência de acidentes.

A análise histórica de acidentes é realizada por meio de consulta a bancos de dados e referências bibliográficas especializadas, de forma que sejam levantadas informações para a avaliação do cenário, como causas, tipologias de acidentes, impactos ambientais, vítimas, entre outras, sendo parte fundamental para a detecção de situações propícias a acidentes, bem como, para facilitar a implantação de medidas preventivas e corretivas.

Neste estudo, cujo objetivo é analisar acidentes envolvendo o TRPP, em um trecho da pista Norte, sentido ascendente, da Rodovia dos Imigrantes foram pesquisados dados sobre Emergências Químicas, na Cetesb - Companhia de Tecnologia de Saneamento Ambiental e no DataGeo - Sistema Ambiental Paulista, obtendo dados específicos do nitrato de amônio, assim como de outros tipos de produtos perigosos que circulam na rodovia.

Segundo dados estatísticos apurados no portal da Cetesb, foram computados 59 acidentes envolvendo o TRPP, desde o início do monitoramento das Emergências Químicas pela Cetesb, em 1998. Desse total, 2 ocorrências foram relacionadas ao transporte de Nitrato de Amônio, representando 4\% do total e 1\%, ligado a acidente envolvendo Amônia Anidra. Vale lembrar que há registro de ocorrência de acidente, envolvendo Nitrato de Cálcio, substância enquadrada na mesma Classe de Risco que o Nitrato de Amônio (Risco 5.1 - Substâncias Oxidantes da ONU - Organização das Nações Unidas).

Conforme pode ser observado no Gráfico 1, as Classes de Risco em que houve maior frequência de acidenes foram: Líquidos Inflamáveis (Classe 3), como petróleo e derivados, com um total de 27 acidentes (36\%), seguido de Corrosivos (Classe 8), com 22 ocorrências, que representam $30 \%$ do total de acidentes. 
Gráfico 1 - Classes de Produtos Perigosos da ONU e Acidentes Ocorridos na Rodovia dos Imigrantes, no período compreendido entre 1998 e 2020.

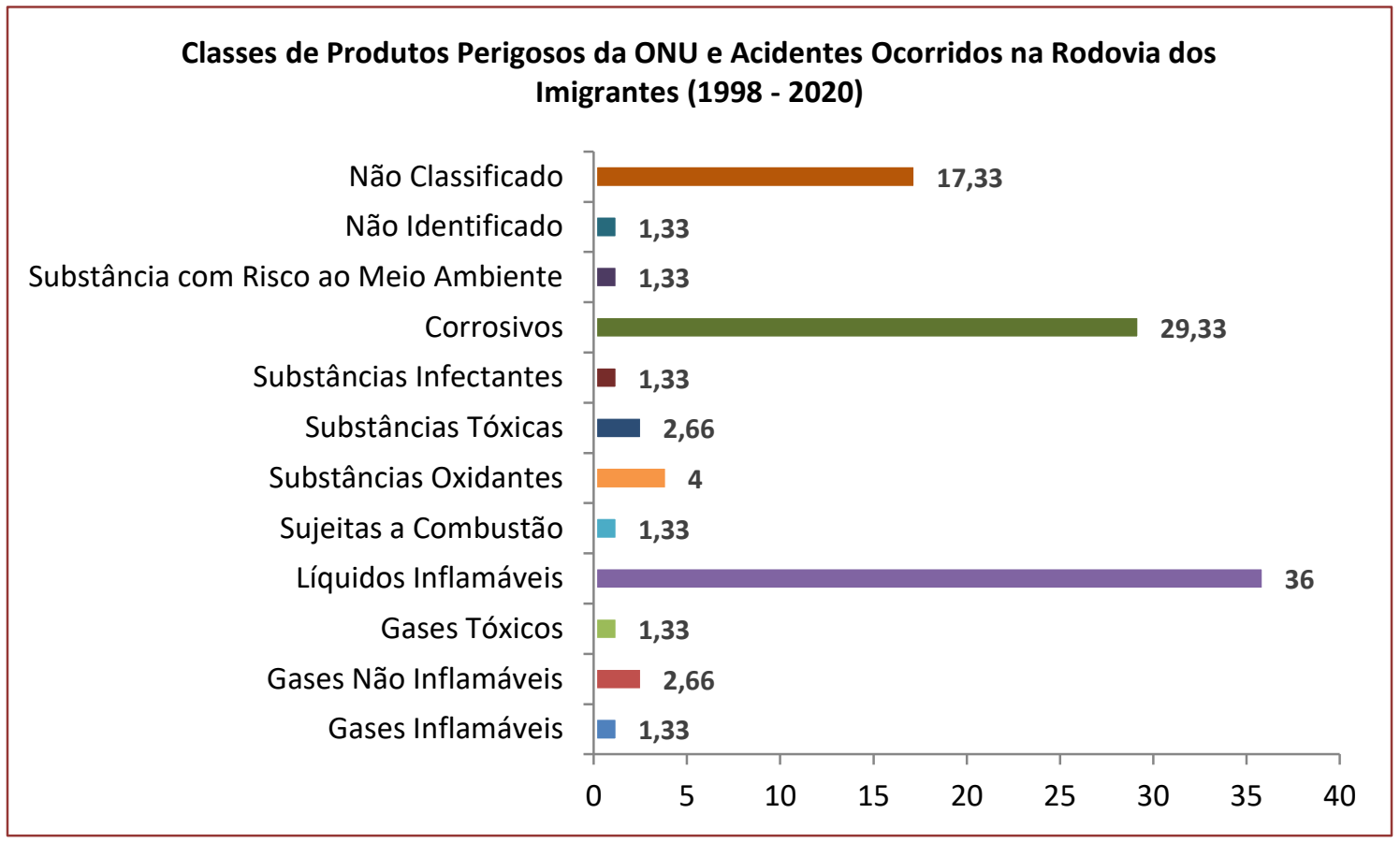

Fonte: Emergências Químicas Cetesb, 2020.

Quadro 2 - Localização, Número e Áreas Afetadas por Acidentes Associados ao Transporte Rodoviário de Produtos Perigosos, na Rodovia dos Imigrantes, entre 2019 e 2020.

\begin{tabular}{|c|c|c|c|c|c|}
\hline № de Acidentes & \multicolumn{1}{c}{ Tipo } & \multicolumn{2}{c}{ Ano } & Área & Município \\
\hline 4 & Rodoviário & $2019 / 2020$ & Rodovia SP 050 - Anchieta & P.E. Serra do Mar & Cubatão \\
\hline 5 & Rodoviário & $2019 / 2020$ & Polo Petroquímico de Cubatão & Industrial & Cubatão \\
\hline 2 & Armazenamento & $2019 / 2020$ & Polo Petroquímico de Cubatão & Industrial & Cubatão \\
\hline 3 & Indústria & $2019 / 2020$ & Polo Petroquímico de Cubatão & Industrial & Cubatão \\
\hline 1 & Outras & $2019 / 2020$ & Polo Petroquímico de Cubatão & Industrial & Cubatão \\
\hline
\end{tabular}

Fonte: Emergências Químicas Cetesb, 2020.

Ainda, no Quadro 2, pode ser observada a localização (por quilômetro), a quantidade e a área afetada por acidentes ocorridos, entre 2019 e 2020, envolvendo o TRPP, entre os trechos 34 e 64 da Rodovia dos Imigrantes. Bem como, no Quadro 3, podem ser observados acidentes não apenas associados ao TRPP, mas também relacionados à Armazenagem e à Indústria de produtos químicos. Estes dados são relevantes, por se tratar de eventos ocorridos na AID - Área de Influência Direta do empreendimento (Polo Petroquímico de Cubatão e áreas adjacentes).

Quadro 3 - Localização, Tipo e Número de Acidentes Associados ao Transporte Rodoviário, Armazenagem e Indústria de Produtos Perigosos, na AID da Rodovia, entre 2019 e 2020.

\begin{tabular}{|c|c|c|c|c|c|}
\hline № Acidentes & Tipo & Ano & Km & Área & Município \\
\hline 2 & Rodoviário & $2019 / 2020$ & 34 & APRM Billings & São Bernardo do Campo \\
\hline 1 & Rodoviário & $2019 / 2020$ & 35 & APRM Billings & São Bernardo do Campo \\
\hline 1 & Rodoviário & $2019 / 2020$ & 47 & APRM Billings & São Bernardo do Campo \\
\hline 2 & Rodoviário & $2019 / 2020$ & 64 & P.E. Serra do Mar & Cubatão \\
\hline
\end{tabular}




\subsection{MAPEAMENTO DA VULNERABILIDADE E DOS RISCOS}

Com o objetivo de melhor adaptar as ferramentas, a Rodovia foi segmentada em trechos menores, afim de organizar as informações. Dessa forma, o critério utilizado para divisão da rodovia foi a diferenciação geográfica, obtendo as seguintes categorias:

- Trecho 1 - Área de Planalto - (Km 35 - 57),

- $\quad$ Trecho 2 - Área de Túneis - (km 57 - 64),

- $\quad$ Trecho 3 - Área de Planície Litorânea - (km 64 - 74).

De maneira geral, a área de Planalto é caracterizada por ser um trecho de Manancial representado pela APRM Billings - Área de Proteção e Recuperação dos Mananciais, ou seja, uma área sensível a ocorrências por emergências químicas. Já a área de túneis é marcada pela presença da Serra e do Parque Estadual da Serra do Mar, uma U.C - Unidade de Conservação de Uso integral. Trata-se de uma área acidentada e com a presença de aclives, que foram atenuados pelo desenho geométrico reto, utilizado na construção desta parte da Rodovia. Por fim, o trecho de Planície é marcado pela vegetação de Mata Atlântica, Manguezais e rios que desembocam no oceano Atlântico. Outra característica importante desta área é a presença do Polo Petroquímico de Cubatão, que propiciou a ocupação urbana e industrial da região.

A definição por trechos possibilitou a identificação de segmentos críticos ou de maior vulnerabilidade a eventos de Emergência Química, em virtude de suas características, tais como: trecho com ventos fortes, trecho sujeito a neblina, com cruzamento de infraestruturas importantes, como dutovias e ferrovias, entre outras classificações. Esses segmentos podem ser identificados com detalhe no Quadro 4, a seguir.

Quadro 4 - Segmentos da Rodovia com maior Vulnerabilidade e Risco de Acidentes

\begin{tabular}{|c|c|c|c|c|c|}
\hline Trecho & Nome & $\begin{array}{c}\mathbf{K m} \\
\text { Inicial }\end{array}$ & $\begin{array}{c}\mathrm{Km} \\
\text { Final }\end{array}$ & Caracterís tica & Municipio(s) \\
\hline 1 & Massa d água permanente & 35 & 47 & APRM Billings & $\begin{array}{l}\text { São Bernardo do } \\
\text { Campo }\end{array}$ \\
\hline 1 & Ventos Fortes & 37 & 38 & APRM Billings & $\begin{array}{l}\text { São Bernardo do } \\
\text { Campo }\end{array}$ \\
\hline 1 & Trecho Sujeito a Neblina & 37 & 56 & Sujeito a Neblina & $\begin{array}{l}\text { São Bernardo do } \\
\text { Campo e São } \\
\text { Vicente }\end{array}$ \\
\hline 1 & Ferrovia & 46 & 48 & APRM Billings & $\begin{array}{l}\text { São Bernardo do } \\
\text { Campo }\end{array}$ \\
\hline 1,2 e 3 & $\begin{array}{c}\text { Parque Estadual da Serra do } \\
\text { Mar }\end{array}$ & 47 & 68 & $\begin{array}{c}\text { Unidade de } \\
\text { Conservação Estadual } \\
\text { Uso Integral }\end{array}$ & $\begin{array}{c}\text { São Bernardo do } \\
\text { Campo, São } \\
\text { Vicente e } \\
\text { Cubatão }\end{array}$ \\
\hline 3 & Massa d água permanente & 69 & 74 & $\begin{array}{l}\text { UGRHI } 7 \text { Baixada } \\
\text { Santista }\end{array}$ & $\begin{array}{l}\text { Cubatão e São } \\
\text { Vicente }\end{array}$ \\
\hline 3 & Dutovia Merluza/Cubatão & 62 & 67 & P.E. Serra do Mar & Cubatão \\
\hline 3 & Ferrovia & 67 & 68 & P.E. Serra do Mar & Cubatão \\
\hline
\end{tabular}

Fonte: DataGeo (2020); Ministério da Infraestrutura (2020). 


\section{CONSIDERAÇÕES FINAIS}

Finalmente, para completar a avaliação sobre os cenários de vulnerabilidade e de risco de acidentes na Rodovia são apresentados em anexo, o Rotograma e a base de dados sistematizada. Trata-se da conclusão do produto cartográfico proposto, composto por 4 Cartas Temáticas sequenciais que representam o traçado Norte da Rodovia dos Imigrantes, na escala 1:50.000.

Nesta etapa do projeto foi necessário trabalhar na definição de simbologias, linguagens e na apresentação das informações analisadas, para permitir uma adequada representação dos fenômenos. Vale ressaltar, que existe um padrão de representação cartográfico, comumente adotado na elaboração deste tipo de estudo, para facilitar a compreensão dos assuntos. Neste projeto, tal rigor científico não foi pretendido, em razão do nível de domínio técnico das ferramentas utilizadas. Entretanto, é necessário ressaltar que, tal falta de padrão não incorreu em prejuízos ao trabalho.

Tendo isso posto e a partir dos levantamentos e análises realizados, a seguir são propostas considerações acerca de medidas básicas de gerenciamento de risco, para os pontos e segmentos identificados, que possuem maior criticidade na Rodovia:

- $\quad 0$ nível da vulnerabilidade do traçado ascendente da Imigrantes está relacionado à presença dos corpos d'água, sobretudo aos cruzamentos com braços e remansos da represa Billings e dos mananciais da Baixada Santista e aos ambientes sensíveis da Serra do Mar;

- $\quad$ Existe ainda, grande risco de acidente e vulnerabilidade ambiental, com maior presença nas Obras de Arte Especiais, em função das intersecções das vias Anchieta e Imigrantes. Este aspecto é determinante para um nível mais crítico, principalmente no Trecho 3 - Planície Litorânea;

- $\quad$ É recomendável a manutenção de medidas que busquem o máximo de segurança na operação da Rodovia, referendadas em Planos de Gerenciamento de Risco, os quais norteiam a atuação das equipes de emergência, dos programas de comunicação, dos sistemas de sinalização e dos programas de manutenção da rodovia.

\section{REFERÊNCIAS}

[1]. ANDA - ASSOCIAÇÃO NACIONAL PARA DIFUSÃO DE ADUBOS. Guia Técnico para Armazenagem, Manuseio e Transporte Seguro do Nitrato de Amônio Fertilizante. São Paulo: ANDA, 2018. Disponível em: http://anda.org.br/wpcontent/uploads/2018/10/Guia_Tecnico.pdf. Acesso em: 20 out. 2020.

[2]. BALLOU, Ronald H. Gerenciamento da cadeia de suprimentos/logística empresarial. tradução Raul Rubenich. - 5. ed. - Porto Alegre: Bookman, 2006.

[3]. CETESB - COMPANHIA AMBIENTAL DO ESTADO DE SÃO PAULO. Estatísticas de Emergências Químicas. Disponível em:

https:www.google.com/search?q=emergencias+quimicas+cetesb\&oq=emergenc\&aqs=chrome.2.69i57j0i433j69i59j0i 43312j69i6013.4063j0j9\&sourceid=chrome\&ie=UTF-8. Acesso em 18 de outubro de 2020.

[4]. CUNHA, W. C. Análise do Transporte de Produtos Perigosos no Brasil. Tese de Doutorado pela Universidade Federal Rio de Janeiro: UFRJ/COPPE, 2009.

[5]. DATAGEO - INFRAESTRUTURA DE DADOS AMBIENTAIS ESPACIAIS DO ESTADO DE SÃO PAULO. Base de dados Cartográficos. Disponível em: https:datageo.ambiente.sp.gov.br/. Acesso em 18 de outubro de 2020.

[6]. DNIT - DEPARTAMENTO NACIONAL DE INFRAESTRUTURA DE TRANSPORTES. Manual para Implementação de Planos de Ação de Emergência para Atendimento a Sinistros Envolvendo o Transporte Rodoviário de Produtos Perigosos. Rio de Janeiro, 2005.

[7]. GUARÇONI, André. Nitrato de amônio na agricultura: uso do fertilizante não oferece perigo.

Entrevista concedida a Andreia Ferreira. Incaper, Espírito Santo, 2020. Disponível em:

https://incaper.es.gov.br/Not\%C3\%ADcia/nitrato-de-amonio-na-agricultura-uso-do-fertilizante-nao-oferece-perigo. Acesso em: 08 out. 2020.

[8]. IBGE. Estatística de Quantidade de fertilizantes entregue ao consumidor final por tipo de nutriente. 2015. Disponível em: https://sidra.ibge.gov.br/tabela/770\#resultado. Acesso em: 19 de maio de 2020.

[9]. MINISTÉRIO DA INFRAESTRUTURA. Mapas e Bases de Dados dos Transportes. Disponível em: https://www.gov.br/infraestrutura/pt-br/assuntos/dados-de-transportes/bit/bitmodosmapas. Acesso em 18 de outubro de 2020

[10]. NORONHA, Daisy Pires; FERREIRA, Sueli Mara S. P. Revisões de literatura. In: CAMPELLO, Bernadete Santos; CONDÓN, Beatriz Valadares; KREMER, Jeannette Marguerite (orgs.) Fontes de informação para pesquisadores e profissionais. Belo Horizonte: UFMG, 2000. 
[11]. OLIVEIRA, SUZELI DE. Dissertação de Mestrado: Riscos associados à armazenagem e transporte de fertilizante nitrato de amônio. Universidade Federal do Paraná. Curitiba, 2013.

[12]. PEDRO DURAN (São Paulo). Cnn. Nitrato de amônio é controlado pelo Exército no Brasil e serve como fertilizante. 2020. Disponível em: https://www.cnnbrasil.com.br/internacional/2020/08/05/nitrato-de-amonio-econtrolado-pelo-exercito-no-brasil-e-serve-como-fertilizante. Acesso em: 08 out. 2020.

[13]. PIRES, S. R. I. Gestão da Cadeia de Suprimentos (Supply Chain Management): Conceitos, estratégias, práticas e casos. Editora Atlas. São Paulo, 2004.

[14]. POFFO, Íris Regina F.; GOUVEIA, Jorge Luiz Nobre; HADDAD, Edson. Acidentes ambientais e comunicação de riscos. Revista Meio Ambiente Industrial e Ag Comunicação Ambiental, São Paulo, p. 52-55, ago. 2005.

[15]. PRODANOV, CLEBER CRISTIANO. Metodologia do trabalho científico [recurso eletrônico]:métodos e técnicas da pesquisa e do trabalho acadêmico 2. ed. Novo Hamburgo: Feevale, 2013.

[16]. SÃO PAULO. CETESB. Relatório de Emergências Químicas. 2020. Disponível em: https://sistemasinter.cetesb.sp.gov.br/emergencia/relatorio.php. Acesso em: 11 out. 2020.

[17]. SPIGOLON, L.M.G. Notas de aula. Transporte de cargas especiais e perigosas. Faculdade de Tecnologia FATEC GUARULHOS., 2010.

[18]. UNIVERSIDADE FEDERAL DE SANTA CATARINA. Plano Ambiental Emergencial PAE. BR 101/SC - Trecho Sul. Florianópolis, 2011. 


\section{ANEXO 01}

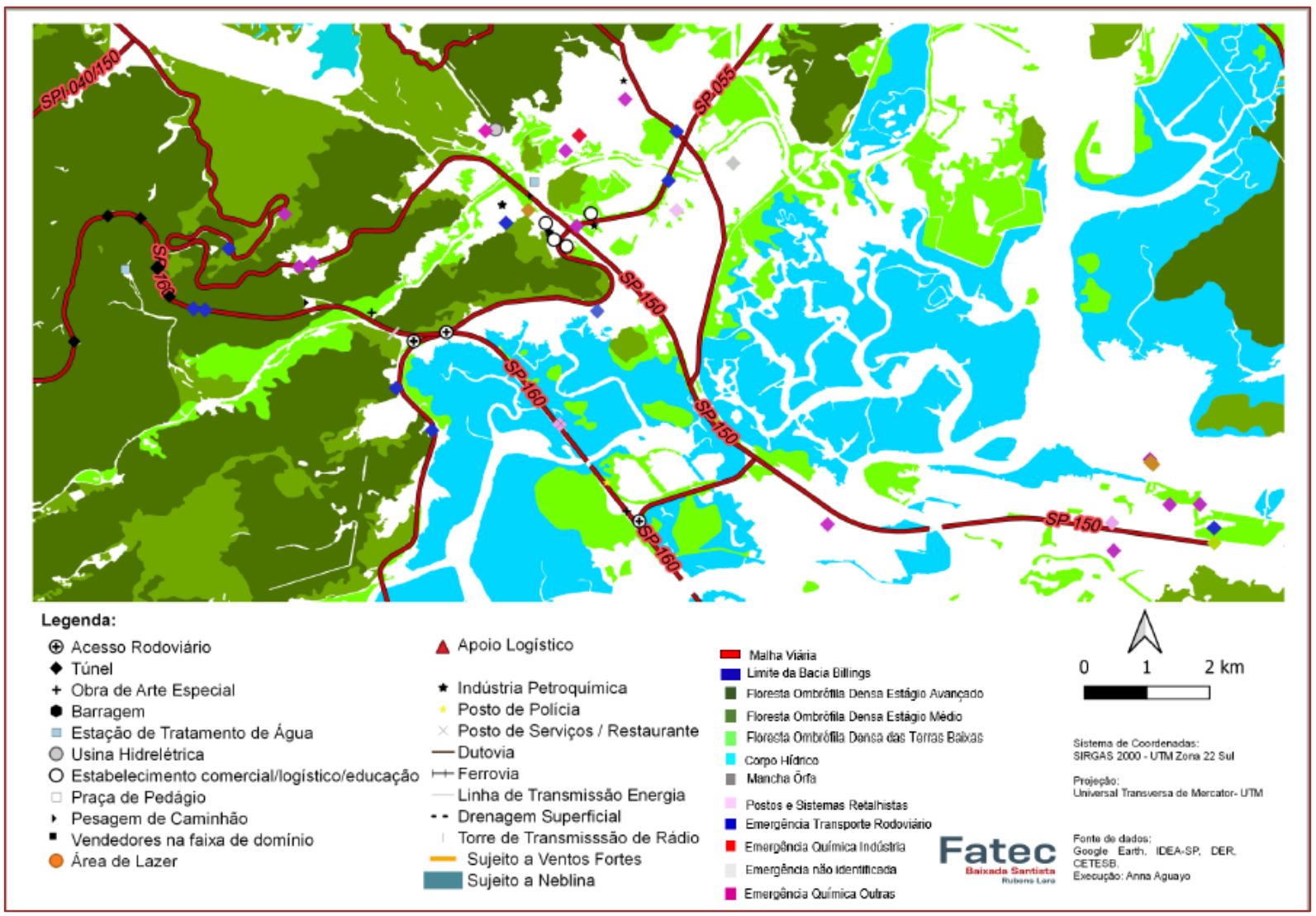

\section{ANEXO 02}

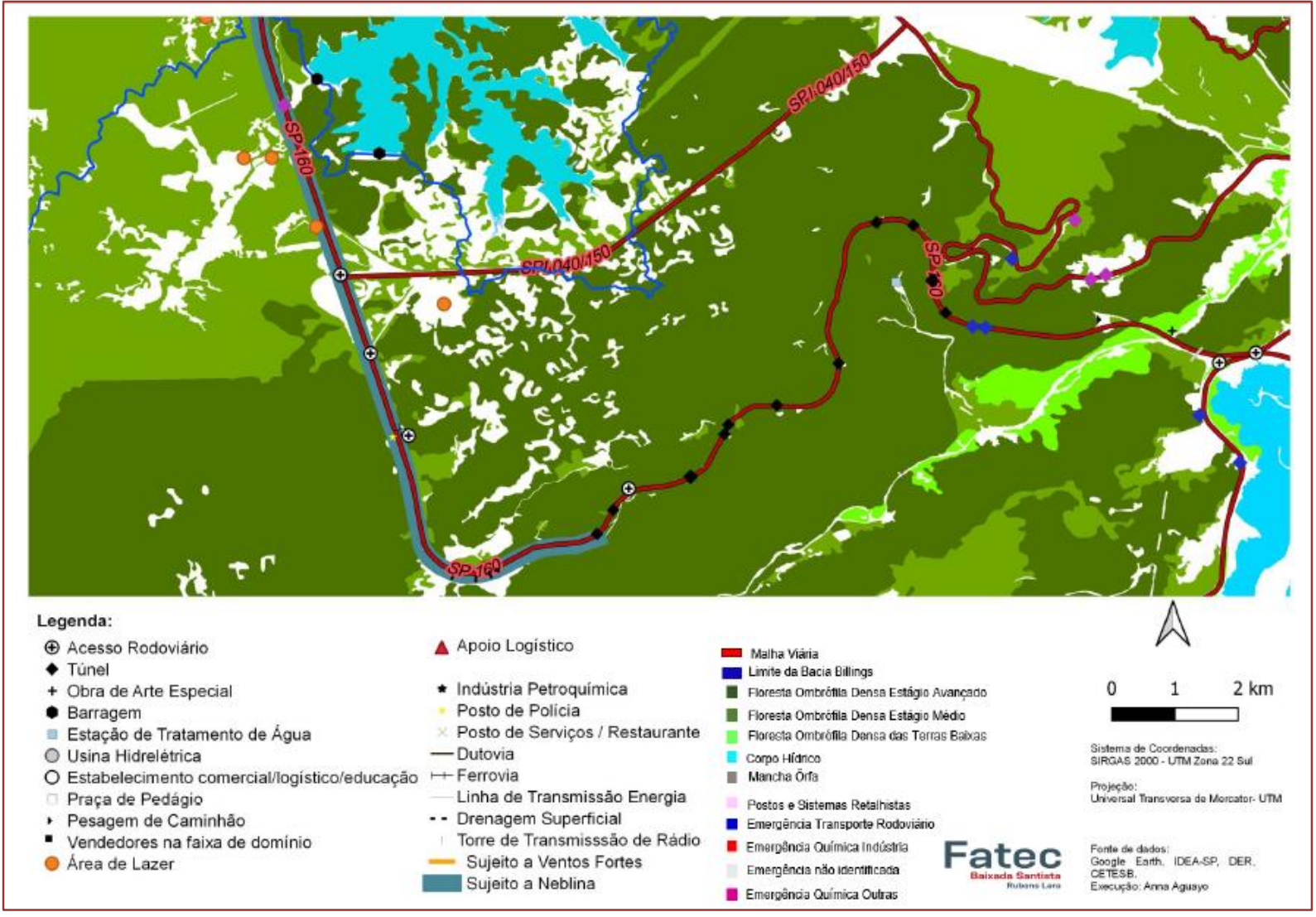




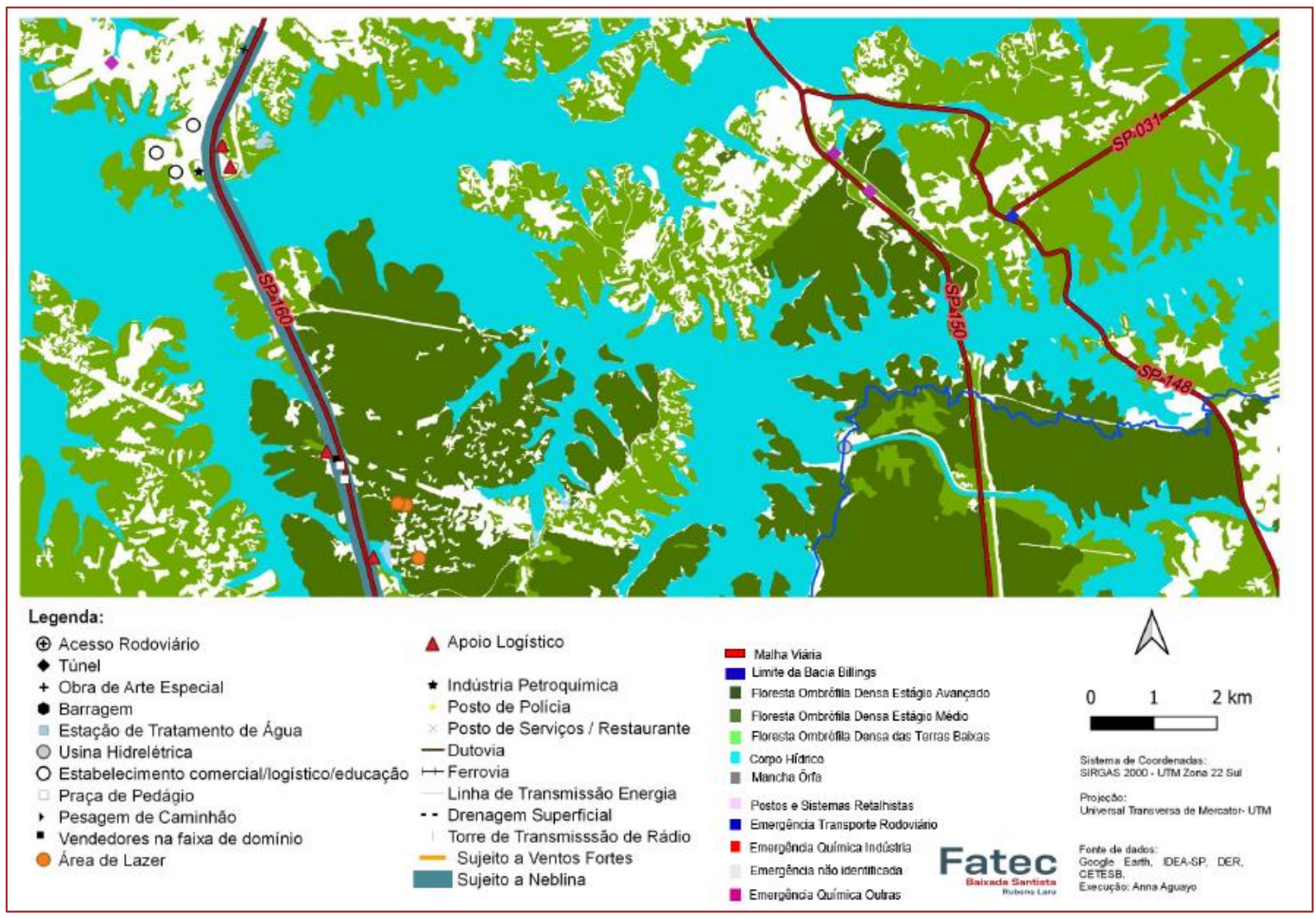

\section{ANEXO 04}

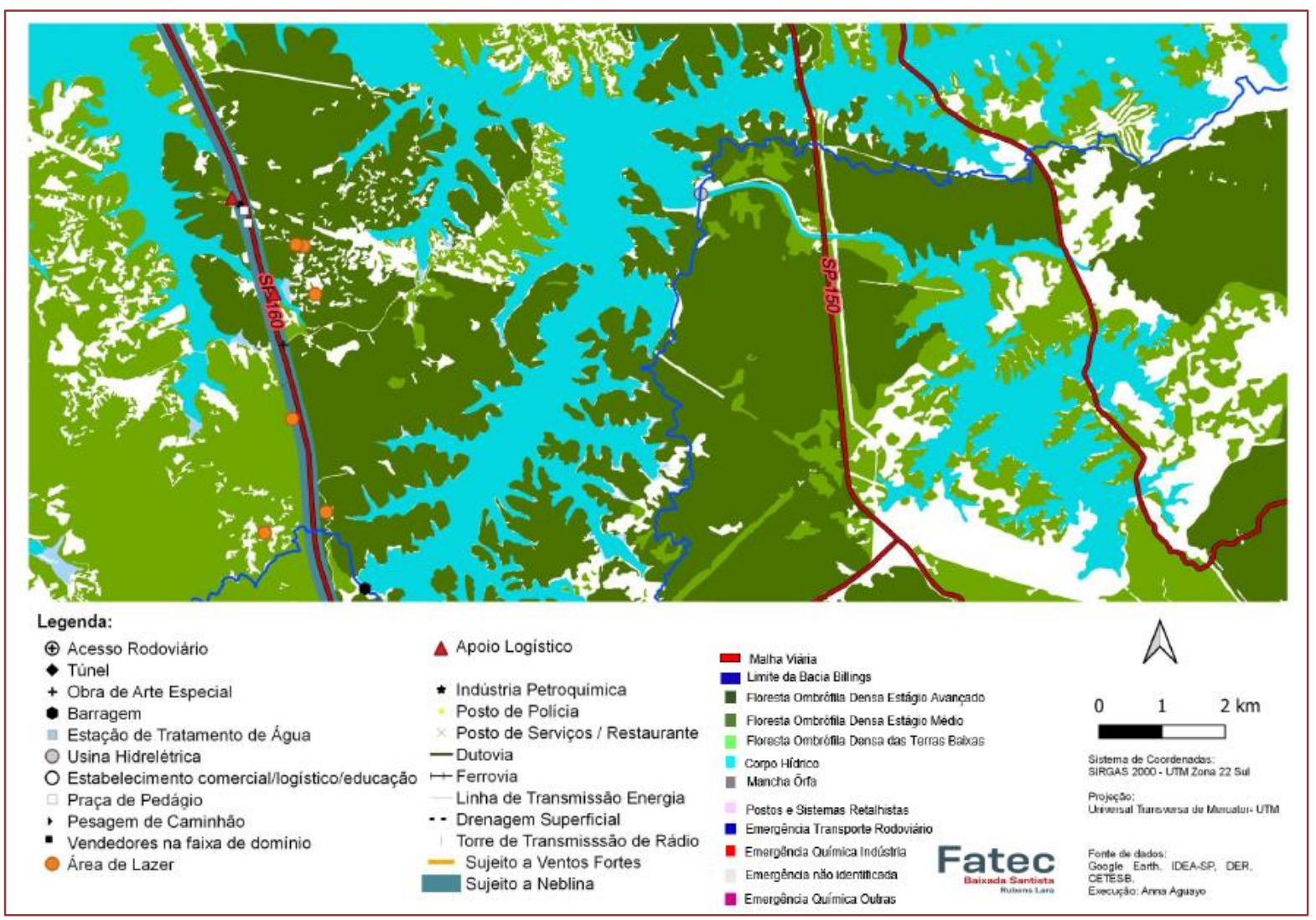




\section{Capítulo 5}

Educar para conservar: Educação Ambiental no Ensino Fundamental II com foco no bioma de Mata Atlântica

\section{Luiz Fernando Ferreira}

Fabiola Mangabeira Ceolato da Silva

Adriele Barrelin de Souza

Ana Caroline Vitor Avelar

Karina Mara Labanca

Raquel Elisamara da Silva Lima

Daniela Ferreira Cardoso

Resumo: A Educação Ambiental na contemporaneidade é uma ferramenta necessária para uma relação consciente entre humanos e o ambiente, mas ela só é efetiva se aplicada aos protagonistas do futuro, ou seja, às crianças, adolescentes e jovens. Sob este contexto, a fim de difundir o conhecimento e a perspectiva do estado da Mata Atlântica, um Hotspot mundial, aplicou-se no Ensino Fundamental II um projeto didáticopedagógico cujo objetivo era ampliar a percepção da importância da conservação da Mata Atlântica a partir da elaboração de um material didático para o ensino de Educação Ambiental. Percebeu-se que estes alunos não reconhecem a fauna local, típica do bioma, além de não conhecerem o bioma no qual o município se encontra inserido. 0 jogo didático se mostrou uma importante ferramenta de avaliação e contribuiu para a promoção da interação e para o despertar da curiosidade para temas tão necessários como a conservação da biodiversidade e de recursos naturais.

Palavras-chave: Conservação; Jogos didáticos; Mata Atlântica. 


\section{INTRODUÇÃO}

O ser humano, em toda sua história, vem modificando a natureza para sanar suas necessidades e desejos, agredindo o meio ambiente sem se preocupar com as consequências dessas ações, até que os resultados, tais como patologias e desequilíbrios ecológicos foram sentidos por ele mesmo, o fazendo repensar seus valores e reconhecer que a natureza apresenta recursos finitos (PALMA, 2005).

A Educação Ambiental é entendida por processos através dos quais, individual ou coletivamente, constroem-se conhecimentos, valores sociais, habilidades e atitudes voltadas à conservação do meio ambiente, ao bem estar comum e à qualidade de vida. Ainda, Educação Ambiental é essencial e permanente da educação nacional, devendo estar presente em todos os níveis e modalidades do processo educativo, sob o enfoque da sustentabilidade, sendo esta desenvolvida como uma prática educativa integrada (BRASIL, 1999; EFFTING, 2007).

A efetivação dos processos envolvidos na Educação Ambiental citados anteriormente estão estritamente relacionados com a percepção que o indivíduo tem do meio ambiente. Essa percepção, por sua vez, é construída histórica e socialmente, com base em vivências de cada cultura (ARAÚJO; SOVIERZOSKI, 2016), e é fundamental para compreender as interrelações entre os seres humanos e a natureza, tais como suas expectativas, julgamentos e condutas (PALMA, 2005).

A Educação Ambiental se destaca no processo educativo para a construção de uma nova visão da relação entre o ser humano e a natureza e na implementação de ações que promovam a conservação do bioma de Mata Atlântica e sua biodiversidade (AGRIZZI et al., 2020), um importante hotspot mundial em função de fatores como a fragmentação ambiental que ameaça toda a sua rica diversidade biológica e seus recursos naturais (MITTERMEIER et al., 2015; MMA, 2014; MONTEIRO-FILHO; CONTE, 2017).

A expansão urbana vem aumentando a degradação das condições de vida, refletindo em uma crise ambiental, isto nos remete a refletir sobre as formas de pensar e agir sobre as questões ambientais numa perspectiva contemporânea (JACOB, 2003). Atualmente no Brasil, segundo as Portarias do Ministério do Meio Ambiente $\mathrm{n}^{\circ} 444$ e $\mathrm{n}^{\circ} 445$ de 17 de dezembro de 2014, são reconhecidas oficialmente 1.173 espécies animais ameaçadas de extinção (MMA, 2014). Deste total, 64\% (627) das espécies ameaçadas ocorrem no bioma de Mata Atlântica, sendo que a fragmentação elevada que o bioma sofreu e vem sofrendo seja a causa para esses números (ICMBIO, 2018).

O bioma de Mata Atlântica se distribui desde o sul até o nordeste do Brasil, ocorrendo em 17 estados brasileiros (FUNDAÇÃO SOS MATA ATLÂNTICA; INPE, 2020), abrigando cerca de metade da fauna de vertebrados do país e apresentando um alto grau de endemismo (ver em MONTEIRO-FILHO; CONTE, 2017). A alta biodiversidade do bioma está associado a suas variações latitudinais (estendendo-se por mais de 27 graus); altitudinais (alcançando até $2.700 \mathrm{~m}$ do nível do mar); e longitudinais, fatores que formaram uma diversidade de habitats (ver em SILVA; CASTELETTI, 2005). Além disso, a Mata Atlântica está isolada das outras duas grandes florestas tropicais (Floresta Amazônica e Florestas Andinas) pelos biomas da Caatinga e Cerrado (SILVA; CASTELETTI, 2005). Esse isolamento resultou em uma biota única com um elevado grau de endemismo (MYERS et al., 2000).

Sob este contexto, o presente trabalho objetivou o desenvolvimento de um projeto a partir da elaboração de um material didático voltado para o ensino de Ciências/Educação Ambiental que visa a importância da conservação da Mata Atlântica, e a aplicação de uma atividade prática e pedagógica com alunos do Ensino Fundamental II de uma escola pública localizada no município de Caconde-SP

\section{MATERIAL E MÉTODOS}

\subsection{PÚBLICO ALVO E ÁREA DE ESTUDOS}

O projeto foi aplicado para 25 alunos do $6^{\circ}$ ano do Ensino Fundamental II, em uma escola pública e estadual no município de Caconde, interior do estado de São Paulo. O município de Caconde/SP está localizado na altitude $21^{\circ} 31^{\prime} 46^{\prime \prime}$ sul e longitude $46^{\circ} 38^{\prime} 38^{\prime \prime}$ oeste a $860 \mathrm{~m}$ de altitude. 0 município é considerado uma das 12 Estâncias Climáticas do estado de São Paulo, com classificação climática segundo Köpper como tropical de altitude (Cwa). 0 bioma predominante no município é o bioma de Mata Atlântica com fitofisionomia típica de Floresta Estacional Semi-decidual. A economia municipal é atribuída principalmente ao cultivo do café (Coffea arabica, Lineu 1753), e ao turismo. 


\subsection{DESENVOLVIMENTO E APLICAÇÃO}

Primeiramente, foi abordado temas importantes relacionados ao bioma, tais como a sua importância e a sua influência na rica biodiversidade brasileira; seus riscos devido a ação antropológica e o histórico da devastação da Mata Atlântica desde a chegada dos portugueses ao Brasil; espécies bandeiras deste bioma e os riscos que elas estão submetidas justamente com o bioma; e medidas da importância das unidades de conservação para este bioma.

Posteriormente, para fixação do conteúdo foi aplicado o material didático desenvolvido: um jogo de tabuleiro denominado "Trilha da Mata Atlântica" (Figura 1A), que foi confeccionado em tecido TNT com dimensões de $140 \mathrm{~cm} \mathrm{X} 200 \mathrm{~cm}$ onde as bases foram feitas com EVA (acetato-vinilo de etileno) representando as árvores.

\subsubsection{REGRAS DO JOGO:}

- $\quad 1$ a: dividir a sala em dois grupos, onde cada grupo é representado por um aluno;

- $\quad 2$ a: cada aluno/jogador escolhe um marcador para registrar o avanço do grupo durante o jogo;

- $\quad 3$ a $:$ ambos os marcadores inicialmente se localizam na primeira base/"casa" do jogo;

- $\quad 4^{a}$ : o primeiro jogador deve jogar o dado e avançar a quantidade de bases que o dado indicar, por exemplo, se o dado cair com a face de número seis para cima este jogador deverá avançar seis bases/"casas";

- $\quad 5^{\underline{a}}$ : algumas bases apresentam cartas (Figura 1B); quando os jogadores pararem nestas, eles devem pegar a carta e ler em voz alta a frase ou pergunta que consta nesta carta, se for uma pergunta, este aluno pode consultar o grupo e este jogador tem 1 (um) minuto para respondê-la, a resposta define se o grupo/jogador avança, retrocede ou continua na base onde está.

- $\quad$ Obs.: cada carta indica a quantidade de bases que este jogador deve avançar, retroceder ou a quantidade de rodadas que este deve jogar ou não jogar.

- $\quad$ 6aㅗ: ganha o jogo aquele que primeiro alcançar a última base.

Durante todo o desenvolvimento do jogo pedagógico, os alunos foram estimulados a participar, a partir do aprendizado despertado durante a prática expositiva e dialogada sobre o bioma Mata Atlântica e ao concluírem, todos receberam uma premiação simbólica: sementes de girassol (Helianthus sp.).

Ao final, foi entregue um folheto informativo, elaborado durante o desenvolvimento do projeto, contendo informações importantes a respeito da atual situação do bioma Mata Atlântica, tendo como expectativa, um compartilhamento dessas importantes informações com familiares e com outros colegas com o intuito de atingir um público-alvo externo ao ambiente escolar.

Figura 1: (A) Jogo confeccionado para a prática; (B) Cartas que compõe jogo.
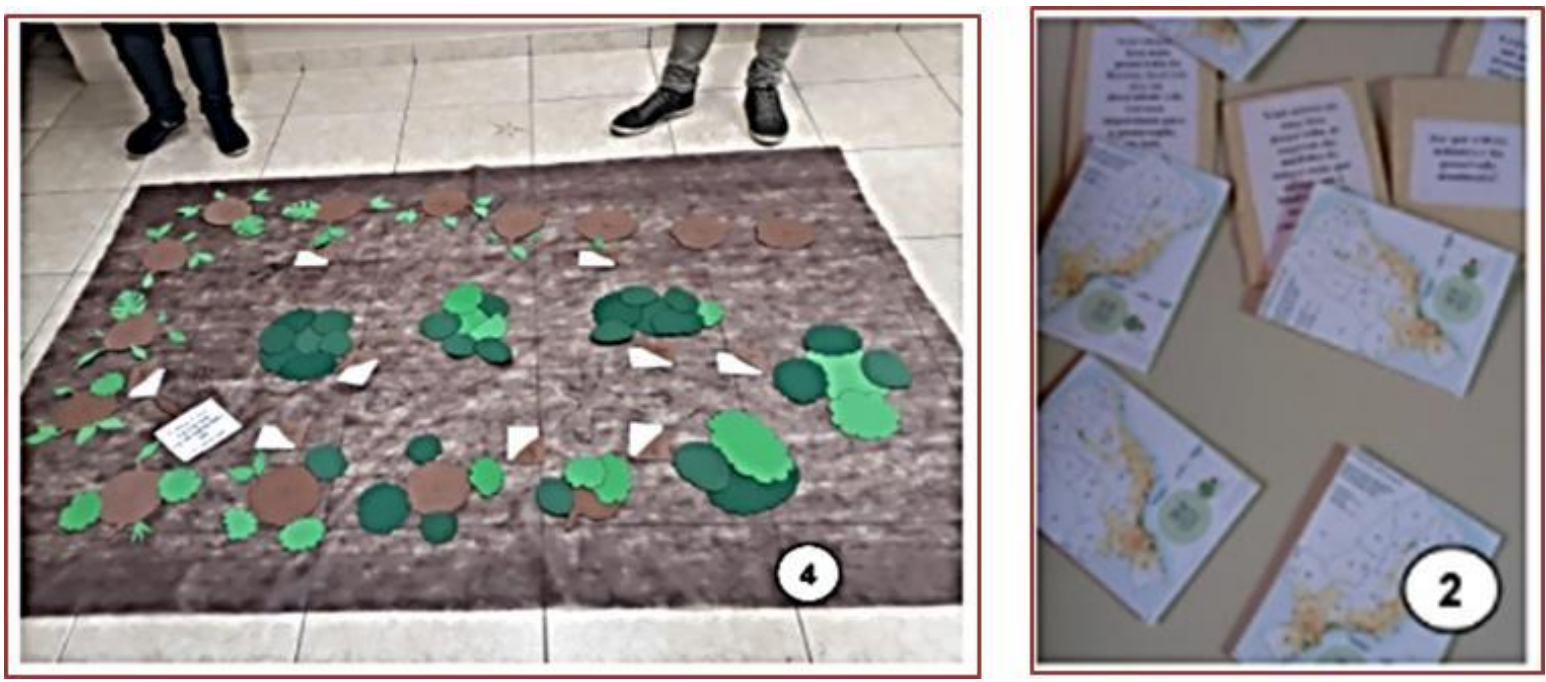


\section{RESULTADOS E DISCUSSÕES}

0 jogo didático-pedagógico foi aplicado para um total de 25 (vinte e cinco) alunos e apenas 1 (um) deste montante sabia que a Mata Atlântica era um bioma; nenhum deles sabia que o município de Caconde/SP está localizado em uma área com predominância no bioma Mata Atlântica, consequentemente, os mesmos desconheciam os riscos que este bioma está correndo. Essa desinformação pode estar relacionado ao fato que conteúdos relacionados a ecossistemas e biomas seja trabalhado no $7^{\circ}$ ano do ensino fundamental segundo a BNCC, na unidade temática "Vida e Evolução" (BRASIL, 2021), e os alunos do presente trabalho cursavam o $6^{\circ}$ ano. Provavelmente pelo pouco conhecimento que possuíam sobre o bioma estudado, foi despertado muita curiosidade dos alunos, os quais foram extremamente participativos, principalmente durante a aplicação do jogo de tabuleiro, pois, conforme o observado por Safar (2019), os jogos atraem mais a atenção dos alunos do que aulas expositivas, além de promover mais interesse e entusiasmo.

Quando questionados acerca da fauna que compõe o bioma de Mata Atlântica os alunos citaram animais da savana africana, como o leão e a zebra podendo estas respostas serem atribuídas a grande repercussão midiática desta biodiversidade, em contrapartida, a ameaça que a fauna brasileira está submetida pode não estar incluso no conhecimento destes alunos. Outro fator que despertou atenção, foi o fato dos alunos não se considerarem como indivíduos pertencentes deste ambiente, se excluindo da fauna, tendo sido isso observado também por Castoldi, et al. 2009 com alunos do Ensino Médio.

Durante a aplicação do jogo de tabuleiro ficou evidente que a utilização deste material didático auxiliou para o esclarecimento de algumas dúvidas e contribuiu para o despertar de novos assuntos relacionados com a temática de Educação Ambiental. Segundo Silva, Almeida e Lima (2019) essas metodologias, por apresentarem como característica o lúdico, são importantes ferramentas motivadoras, pois promovem a praticidade e a visualização do que foi trabalhado teoricamente, sendo ferramentas estratégicas para o despertar do interesse e da motivação, pois possuem maneiras mais atraentes para o aprendizado dos alunos, complementando a construção do conhecimento.

\section{CONCLUSÕES}

O ensino de Educação Ambiental representa um importante componente curricular interdisciplinar, que nos faz refletir sobre a necessidade de uma relação harmônica com o meio ambiente onde vivemos. A forma tradicional com que o ensino vem sendo abordado, no que diz respeito à construção de conhecimento e transformação social, tem sido insuficiente (CARVALHO; PACHECO; RODRIGUES, 2012), nesse contexto, a utilização do jogo como recurso didático-pedagógico contribuiu para um aprendizado mais significativo, pois trouxe, por meios lúdicos e dinâmicos, o conhecimento da importância e do atual estado do bioma de Mata Atlântica.

\section{REFERÊNCIAS}

[1] AGRIZZI, A. P. Et al. Projeto Saberes da Mata Atlântica: percepção ambiental e científica de estudantes do entorno do Parque Estadual da Serra do Brigadeiro (MG). Revbea, São Paulo, v. 15, n. 7, p. 277-296, 2020.

[2] ARAÚJO, B. F.; SOVIERZOSKI, H. H. Percepção dos alunos do ensino médio sobre os biomas de Mata Atlântica e Caatinga. Revista Práxis. v. 8, n. 16, p. 81-94, dez. 2016.

[3] BRASIL. Lei $\mathrm{n}^{\circ}$ 9.795, de 27 de abril de 1999. Brasília, DF, abr 1999. Disponível em: <http://www2.mma.gov.br/port/conama/legiabre.cfm?codlegi=321> Acesso em: 20 jun 2019.

[4] BRASIL, MINISTÉRIO DA EDUCAÇAÕ. Base Nacional Comum Curricular. 2021, Disponível em: <http://basenacionalcomum.mec.gov.br/abase/> Acesso em: 3. mai. 2021.

[5] CARVAlHO, E. B.; PACHECO, K. F. G.; RODRIGUES, G. O jogo didático "Jogo dos biomas" como método de ensino e aprendizagem. Anuário da Produção Acadêmica Docente, São Paulo, v. 5, n. 10, p. 75-86, nov. 2012.

[6] CASTOLDI, F.; BERNARD, R.; POLINARSKI, C.A. Percepção dos problemas ambientais por alunos do ensino médio. Revista brasileira de ciências, tecnologia e sociedade, São Carlos, v. 1, n. 1, p.56-80, 2009.

[7] EFFTING, T.R. Educação ambiental nas escolas públicas: realidades e desafios. 2007. 90 f. Monografia (Especialização em Planejamento para o desenvolvimento sustentável) - Programa de Pós-Graduação, Faculdade de Ciências Agrárias da Universidade Federal do Oeste do Paraná, Marechal Cândido Rondon, 2007. 
[8] FUNDAÇÃO SOS MATA ATLÂNTICA; INPE. Atlas dos remanescentes florestais da Mata Atlântica: Período 2018 - 2019: Relatório Técnico. São Paulo: INPE, 2020.

[9] JACOB, P. Educação ambiental, cidadania e sustentabilidade. Cadernos de pesquisa, São Paulo, n. 118, p.118205, mar. 2003.

[10] ICMBIO. Livro vermelho da fauna ameaçada de extinção: volume I. Brasília. DF: ICMBio/MMA, 2018.

[11] MITTERMEIER, R. A.; FONSECA, G. A. B.; RYLANDS, A. B.; BRANDON, K. A brief history of biodiversity conservation in Brazil. Conservation biology. Washington, v.19, n.3, p. 601,607, 2005.

[12] MMA. Portaria $\mathrm{n}^{\circ} 444$ de 17 de dezembro de 2014/ Portaria ${ }^{\circ} 445$ de dezembro de 2014. Disponível em: \&lt;https://www.icmbio.gov.br/sisbio/images/stories/instrucoes_normativas/PORTARIA_N\%C2\%BA_444_DE_17_DE _DEZEMBRO_DE_2014.pdf\&gt; Aceso em: 2. fev. 2021.

[13] MONTEIRO-FILHO, E. L. A.; CONTE, C. E. Revisões em Zoologia: Mata Atlântica. 1. Ed. Curitiba: UFPR, 2017.

[14] MYERS, N. et al. Biodiversity hotspots for conservation priorities. Nature. v.403, n.24, feb. 2000.

[15] PALMA, I. R. Análise da percepção ambiental como instrumento ao planejamento da educaçaõ ambiental. 2005. 83 f. Dissertação (Mestrado em Engenharia) - Programa de Pós-Graduação da Universidade Federal do Rio Grande do Sul, Porto Alegre, 2005.

[16] SAFAR, L. M. O. O uso do jogo baralhomas como forma de avaliação de aprendizagem no ensino fundamental - anos finais. 23f. 2019. Monografia (Faculdade em Educaçaõ em Ciências) Universidade Federal de Minas Gerais, Contagem, 2019.

[17] SILVA, J. M. C.; CASTELETTI, C. H. Estado da biodiversidade da Mata Atlântica Brasileira. In: LEAL C. G.; CÂMARA, I. G. (Org). Mata Atlântica, biodiversidade, ameaças e perspectiva. Belo Horizonte: Fundação SOS Mata Atlântica, Conservação Internacional e Centro de Ciências Aplicadas à Biodiversidade, 2005.

[18] SILVA, J. R.; ALMEIDA, W. A.; LIMA, R. A. Biomas brasileiros: um jogo educativo para o ensino fundamental em uma escola pública no Alto Solimões, Amazonas. SAJEBTT, Rio Branco, v. 6, n. 1, p. 408-417, jun. 2019. 


\title{
Capítulo 6
}

\section{Aspectos alimentares da palma forrageira (Opuntia ficus indica L. Mill) no Semiárido do Brasil}

\author{
Ana Elisabeth Cavalcanti Santa Rita \\ Xirley Pereira Nunes \\ David Fernandes Lima \\ Márcia Bento Moreira \\ Carlos Henrique Brandão Gomes
}

Resumo: 0 objetivo deste artigo é discutir o uso alimentar da palma forrageira. A motivação surgiu pela observação da carência de alimentos nutritivos no semiárido brasileiro percebidas principalmente no período da estiagem, e a oportunidade de utilização deste vegetal em vários formatos que não somente o uso alimentar para animais. Pretende-se uma revisão de literatura a respeito do assunto. Utilizou-se como metodologia a revisão sistemática. Após aplicação dos descritores em 6 bases de dados selecionadas, encontrou-se um total 497 artigos, os quais foram submetidos aos critérios de inclusão e exclusão. Foram incluídos 14 artigos que abordam estudos etnobotânicos. Um total de 21 artigos atendeu na totalidade aos critérios de inclusão e exclusão, e destafeita selecionados para análise. Como resultado observa-se grande quantidade de artigos relacionados ao consumo animal, bem como ao uso agrícola da palma forrageira, e escassez de artigos direcionados para o consumo alimentar humano deste vegetal. Verificou-se que a palma vem se destacando no cenário alimentício ao longo dos anos. Tanto como vetor na indústria têxtil, quanto na alimentação animal e humana.

Palavras-Chave: palma forrageira; Opuntia fícus indica; alimento humano; alimento animal; caatinga. 


\section{INTRODUÇÃO}

O Brasil é um país de dimensões continentais e diante de território tão vasto observa-se uma imensa variedade de fauna, flora, biomas e diversidade cultural. No ano de 1889 foram registradas as primeiras estimativas oficiais para registro da área territorial baseadas na Carta do Império do Brasil, publicada em 1883. Os dados daquela época foram atualizados pelo Instituto Brasileiro e Geográfico (IBGE), o qual passou a ser responsável pela revisão da área geográfica nacional após a promulgação do Decreto-Lei $\mathrm{n}$ 은 237, de 02/02/1938, sendo a extensão territorial atual de 8.515.767,049 km² (IBGE, 2012).

Dentro de um país com a maior extensão territorial da América do Sul, há grande variedade de climas, relevos, solos, flora e fauna. Ainda de acordo com o IBGE (2012), as áreas totais cultivadas em território nacional perfazem $10,47 \%$ da área total do solo nacional, fato que abre espaço para muitos cultivos de diferentes espécies que podem se adequar às diversas situações climáticas.

Compondo o cenário territorial brasileiro encontra-se a região Nordeste, com área aproximada de $1.558 .196 \mathrm{~km}^{2}$. Desta área, $75 \%$ possui clima semiárido e bioma de Caatinga, com níveis pluviométricos de, aproximadamente, 350-800 milímetros anuais (SUASSUNA, 2013).

A biodiversidade brasileira é rica e com potencial para desenvolvimento no campo da agroecologia e desenvolvimento sustentável. Áreas do Brasil com volubilidade climática carecem de culturas que se adequem às intempéries regionais. Em destaque, o clima semiárido do Nordeste brasileiro, no qual as chuvas escassas e em poucos períodos, limitam o cultivo de hortas e frutas, bem como a criação de animais. Diante deste cenário,

A palma forrageira se destaca como planta forrageira ideal para mitigar os efeitos do baixo rendimento da pecuária no semiárido. Se bem manejada, a palma é capaz de atingir altas produtividades, garantindo a suplementação dos animais. Pelas composições químicas não é recomendada em uso exclusivo, mas principalmente compondo o balanço nutricional da dieta e ofertando água aos animais (ROCHA, 2012, p.06).

Ainda segundo Rocha (2012), a palma forrageira tem sua origem no México, mas é amplamente distribuída pela América do Sul. Por ser de fácil manejo e exigir poucos cuidados o cultivo ocorre em diversas regiões e com várias finalidades. Jaimes-Roncancio et al. (2018) confirmam que as palmas desempenham um papel importante em comunidades indígenas estudadas e é evidente a diminuição do conhecimento nos usos associados à cultura e cerimônias rituais. Este fato, somado a outros que aqui serão discorridos, põe em evidência a importância do resgate e do debate do uso desta cactácea e de tantas outras Plantas Alimentícias Não-Convencionais (PANCs) como modo de preservação de conhecimento ancestral.

No Brasil, a palma forrageira é mais comumente utilizada como alimento para os rebanhos bovino, caprino e ovino. É rica em nutrientes, surgindo como opção para alimento humano e opção econômica, principalmente nas regiões de clima semiárido.

\section{OBJETIVO}

Com este estudo, pretende-se realizar uma revisão bibliográfica sistemática sobre os aspectos alimentares da palma forrageira (Opuntia ficus indica L. Mill) no Brasil. Tem como expectativa contribuir para mitigar questões locais, regionais e nacionais no que diz respeito a novos horizontes agroecológicos, com desenvolvimento territorial de sistemas sustentáveis.

\section{METODOLOGIA}

Para a realização deste estudo empregou-se a revisão sistemática da literatura (Rother, 2007), artigos selecionados publicados a partir de 2011, selecionados após aplicação dos critérios de inclusão e exclusão. Para tanto, foi realizada busca sistemática nas bases de dados: Scielo, LILACS, Trópicos, Biblioteca Virtual em Saúde, Researchgate, e Pubmed, no mês de agosto de 2019. Foram pesquisados artigos nos idiomas: português, inglês e espanhol, utilizando-se os descritores "palma" AND "alimento" AND "forrageira" AND "humano" AND "human food" AND "animal food". O operador boleano "AND" foi utilizado visando a obtenção de artigos que continham os dois termos entre aspas simultaneamente no mesmo artigo, 
considerando o título, resumo e palavras-chave. Os artigos com temática pertinente foram selecionados para o estudo.

Utilizou-se como critério de inclusão o uso alimentar humano da palma, uso alimentar animal e o gênero de palma Opuntia fícus indica L. Mill. Como critérios de exclusão, não foram citados na presente revisão os artigos em duplicata, artigos publicados anteriores ao ano de 2011, artigos que explorassem o uso agrícola ou genético, plantas de outras espécies, e os estudos com temática não relacionada ao interesse deste estudo. Chegou-se aos artigos elencados nas referências bibliográficas.

\section{RESULTADOS}

A pesquisa utilizando as palavras-chave realizadas nas plataformas de dados resultou em 9 artigos encontrados na plataforma Scielo; 16 artigos na plataforma LILACS; 8 na Research Gate; 61 artigos na Biblioteca Virtual em Saúde; 2 artigos na Flora do Brasil; e 387 artigos no Google Acadêmico. Foram alvo de apreciação websites das principais revistas brasileiras que publicaram estudos etnobotânico permitiu o acréscimo de mais 14 artigos, após desconsiderar os artigos compartilhados com a pesquisa nos portais de busca.

Foram selecionados, dentre os artigos, após a aplicação dos critérios de inclusão e exclusão, 21 artigos.Observou-se muitos artigos utilizando a palma forrageira (Opuntia fícus indicaL.Mill), porém abordam temas que não a utilização alimentar deste vegetal. Desta forma, observa-se espaço para publicação com o tema em questão. A literatura pertinente ao tema abordado retorna maior abundância de informações relacionadas à agricultura, uso para alimentação animal, mudanças climáticas e palmas de outras espécies. Os resultados encontrados mostram que o Google Acadêmico retornou quantidade expressiva de documentos relacionados aos termos de busca, tanto em língua portuguesa, quanto inglesa, possivelmente por recuperar os documentos contidos nas demais bases.

\section{DISCUSSÃO}

A palma pertence ao gênero Opuntia e, segundo sua hierarquia taxonômica, trata-se de uma angiosperma da família das Cactaceae, tendo como forma de vida arbusto, árvore, erva, liana/volúvel/trepadeira, subarbusto e suculenta. Seu substrato é epífita, hemiepífita, rupícola e terrícola (MILLER, 1768).

No Nordeste do Brasil são encontrados três tipos distintos de palma: a) gigante - da espécie Opuntia fícus indica; b) redonda - Opuntia sp; e c) miúda - Opuntia conchenilifera. De acordo com dados da plataforma Flora do Brasil, para Hunt et al. $(2006,2013)$, a família Cactaceae compreende 128 gêneros e 1450 espécies tendo sua distribuição quase exclusivamente em continente americano, com exceção de Rhipsalis bacifera (Muell) Stearn que ocorre tanto na região neotropical como na África e Madagascar, chegando até o Ceilão. Hunt et al. (2006) cita outros autores e afirma que a família Cactaceae está dividida em quatro subfamílias das quais apenas Pereskioideae, Opuntioideae e Cactoideae ocorrem no Brasil.

Em estudos, o Brazil Flora Group - BFG (2015) reconhecem 39 gêneros e 261 espécies no território brasileiro, dos quais 14 gêneros e 188 espécies são endêmicas, com grande percentagem de espécies ameaçadas de extinção (Goettsch et al. 2015; Ribeiro-Silva et al. 2011).

De acordo com a Agência Embrapa de Informação e Tecnologia, as temperaturas médias anuais do semiárido brasileiro variam entre $26^{\circ}$ e $27,5^{\circ} \mathrm{C}$, sendo que nos meses mais secos a temperatura do solo chega aos $60^{\circ} \mathrm{C}$ e a umidade relativa é baixa, em torno de $50 \%$. Neste canário de condições climáticas rigorosas, a palma forrageira encontrou espaço e se adequou bem por seus aparatos fotossintéticos (Lopes, 2013). Ainda de acordo com o autor, a palma é uma planta forrageira bem adaptada às condições do semiárido nordestino, suportando déficits hídricos, em função das suas propriedades fisiológicas, caracterizadas por um apparatus fotossintético eficiente.

A palma (Opuntia ficus indica L. Mill) produz seu fruto praticamente durante todo ano, conhecido como figo-da-Índia. A fruta é doce, suculenta, comestível, com 5-10 cm de comprimento e $8-10 \mathrm{~cm}$ de largura; piriforme, ligeiramente curvada para o umbigo; amarelo-esverdeada, laranja, vermelha ou púrpura; com muita polpa e uma casca fina (LEUENBERGER, 1991).

De acordo com Lopes além dos frutos, os cladódios, que são ramos de caules modificados, conhecidas como raquetes, também são apropriadas para consumo alimentar. Foi batizada com o nome de "palma" devido ao seu formato lembrar a palma da mão humana. É conhecida popularmente como Palmatória, Palma, Palma-gigante, Figo-da-índia, Figo-da-Espanha, Jamaracá e Jurumbeba. 
Para Lopes (2013) a origem da palma é mexicana e que os tipos de palma cultivados no Brasil são: Gigante e Redonda (Opuntia fícus indica Mill cultivares), e a espécie Miúda (Nopalea cochenilifera - Salm Dyck), que são utilizadas para alimentação animal como forrageira e para humanos, com o aproveitamento do fruto e das raquetes como verdura.

Raniere (2017) afirma que a palma tem potencial pouco explorado. A produção dos frutos para consumo humano, bem como das raquetes para humanos e ruminantes, pode se tornar uma alternativa para desenvolvimento humano e econômico. Pode ser classificada como PANC, por estar classificadas dentre àquelas que são "todas as plantas que poderíamos consumir, mas não consumimos". São utilizadas como alimento humano ou animal, não sendo produzidas ou comercializadas em larga escala para este fim.

Lopes (2013) ressalta que em relação à época de entrada destas espécies no Brasil não é bem definida, sendo esta em meados de 1880, através do Estado de Pernambuco, por sementes trazidas do Texas, nos Estados Unidos.

Frota et al. (2015) reforçam a afirmação de Lopes quanto à entrada da palma no Brasil não possuir dados unânimes, dando a versão que a palma entrou no Brasil por volta de 1877, por empresários interessados na produção do ácido carmínico, produzido pelo inseto cochonilha-do-carmim. Este inseto era hospedeiro na palma e produzia a matéria-prima para a produção do carmim (corante vermelho), utilizado na indústria têxtil. Ainda segundo o autor, os empresários estabeleceram o cultivo da palma e do seu inseto hospedeiro em suas propriedades de Delmiro Gouveia no município de Pedra, em Alagoas; Herman Lundgren, no município de Paulista, em Pernambuco; e no município de Rio Tinto, na Paraíba.

Neste ponto Lopes (2013) e Frota (2015) convergem nas suas afirmações quando é dito que estes empresários lograram êxito e o Brasil passou a produzir tecidos coloridos, competindo com a China e a Índia neste mercado. E anuem quando relatam em seus estudos que o processo de produção do corante carmim para tingimento de tecidos em larga escala foi inviabilizado depois da Primeira Guerra Mundial, pelo crescimento da indústria do petróleo e de seus derivados, como nitritos e nitratos, os quais são produtos utilizados na fabricação de tintas.

Após a queda da indústria da produção dos corantes, os plantadores de palma perceberam a sua resistência à seca e que o gado a apreciava no período da estiagem, passando a ser cultivada como cultura forrageira. Este fato ocorre nos meados de 1932, nesta mesma época uma ação governamental que autoriza a plantação de 200 campos da palma na região Nordeste do Brasil, com intenção de mitigar os efeitos da seca que açoitava a região (LOPES, 2013).

Suassuna (2013) discorre sobre o tema e arremata o que foi inicialmente comentado por Lopes, afirmando que a plantação dos 200 campos de palma ocorreu sob o comando do então Ministro de Viação e Obras, Sr. José Américo de Almeida, por este ter conhecimentos da palma ser resistente à seca, ser cultura rude e que, quando consumida pelo gado, ocasionava em aumento na produção de leite e ganho de peso. A partir de então, a palma passou a ser utilizada como cultura forrageira. Fato interessante citado nos estudos de Suassuna é que

Os agricultores que passaram a cultivar a palma, o fazem de maneira equivocada plantando a palma como forragem utilizando para isso o sistema de produção de corante. 0 resultado disso e que, procedendo dessa maneira, as produtividades da palma sendo cultivada para forragem caem significativamente (SUASSUNA, 2013, p.51).

Os domínios fitogeográficos desta cactácea são a Caatinga, o Cerrado, a Mata Atlântica, o Pampa e o Pantanal.

Para Oliveira et al. (2011), existem aspectos nesta cactácea que favorecem sua adaptação e resistência à seca, sendo eles resistência, tolerância e escape. A resistência pela sua condição xerofítica, a tolerância ligada a fatores bioquímicos, como o metabolismo diminuído e o escape que, por ser superficial e ramificado, lhe possibilita um aproveitamento eficiente das chuvas.

Para Frota et al. (2015),

Um grande diferencial das cactáceas é seu metabolismo CAM (Metabolismo Ácido das Crassuláceas), considerando a chave para o sucesso e sobrevivência em regiões áridas e semiáridas. As plantas CAM abrem seus estômatos durante a noite e os mantêm fechados durante o dia. Por essa razão, conseguem manter 
alta eficiência do uso da água, abrindo os estômatos apenas com as temperaturas mais baixas da noite. Isso minimiza a perda de água, pois $\mathrm{H}_{2} \mathrm{O}$ e $\mathrm{CO}_{2}$ têm a mesma via de difusão (FROTA et al., 2015, p.16)

Além dos aspectos que a tornam mais resistente à seca e ao semiárido, local onde a falta de água seria fator limitante para o desenvolvimento de grande parte de plantas, esta cactácea possui propriedades nutricionais que a tornam interessante não apenas para uso animal, como também para uso humano, como afirmam Vigueras e Portilllo (2013):

Essas plantas podem ser totalmente utilizadas desde frutas, raquetes, sementes e flores podem ser usadas como fonte de fitoquímicos ativos. Fibras, Hidrocolóides, pigmentos, minerais e vitaminas são alguns dos componentes encontrados nas raquetes e frutos de cactos. Além disso, flores e sementes também têm substâncias bioativas de interesse nutracêutico (VIGUERAS e PORTILLO, 2013, p. 95).

Ainda de acordo com Nazareno (2013), as raquetes da palma são ricas em fibras (18\%), como também em minerais, com 4-10\% de proteína, e baixa quantidade de lipídios. As raquetes possuem biopolímeros com carboidratos que lhe conferem a capacidade de reter água.

Na Sicília, Itália, a palma é utilizada para tratamento de úlceras, controle da glicemia em pacientes diabéticos, redução da obesidade, colesterol e triglicerídeos, tendo seu uso cientificamente comprovado. No Brasil estudos desta natureza estão em fase inicial. (NAZARENO, 2013).

Conforme Pinto et al. (2019) os brotos da palma podem ser utilizados como hortaliça em qualquer estágio de desenvolvimento sendo encontrados compostos bioativos como clorofilas, carotenoides e flavonoides, assim como polifenóis e ácido ascórbico. Tal afirmação corrobora o uso da palma como fonte alimentar humana. Diante do novo cenário agroecológico, abre-se espaço para a pesquisa e desenvolvimento de produtos sustentáveis que venham a suprir as necessidades regionais e nacionais, tendo como alvo desenvolvimento territorial e produtos ecologicamente corretos.

A palma teve seu fruto estudado, através de métodos de análise física e físico-química por Oliveira et al. (2011), dos quais resultaram nos dados expressos na Tabela 1 e Tabela 2.

Tabela 1 - Medidas físicas do fruto da palma (Média, Desvio Padrão (DP) e Coeficiente de Variação (CV), $\mathrm{n}=10$ )

\begin{tabular}{|l|c|c|c|c|}
\hline \multicolumn{3}{|c|}{ Comprimento (mm) } & \multicolumn{3}{|c|}{ Tamanho (mm) } & Peso (g) & Densidade $\left(\mathrm{g} / \mathrm{cm}^{3}\right)$ \\
\hline Média & 87,1440 & 51,0580 & 108,693 & 0,9644 \\
\hline Dp & 15,9260 & 3,5325 & 15,6732 & 0,0194 \\
\hline Cv (\%) & 18,28 & 6,93 & 14,42 & 2,08 \\
\hline
\end{tabular}

Fonte: Oliveira et al. (2011) 
Tabela 2 - Medidas físico-químicas do fruto da palma (Média, Desvio Padrão (DP) e Coeficiente de Variação (CV), n=3).

\begin{tabular}{|c|c|c|c|c|}
\hline Variáveis & Valores encontrados & Canuto et al. (2006) & $\begin{array}{l}\text { Sépulveda \& } \\
\text { Saéns (1990) }\end{array}$ & Manica (2002) \\
\hline Umidade (\%) & $80,45 \pm 0,005$ & 87,80 & 83,770 & - \\
\hline Cinzas totais $(\%)$ & $0,4394 \pm 0,0479$ & 0,43 & 0,44 & 0,40 \\
\hline Cinzas solúveis (\%) & $0,0369 \pm 0,0723$ & - & - & - \\
\hline Cinzas insolúveis (\%) & $0,4025 \pm 0,1202$ & - & - & - \\
\hline Açúcares totais (obrix) & 13,0 & 13,45 & 14,06 & 13,42 \\
\hline Açúcares redutores (\%) & $7,2754 \pm 0,5103$ & 11,43 & 14,06 & 19,66 \\
\hline Lipídios (\%) & $\begin{array}{c}0,1485 \pm \\
0,0178\end{array}$ & - & - & 0,23 \\
\hline Ferro (mg/100g) & $1,2083 \pm 0,1938$ & - & 0,40 & - \\
\hline
\end{tabular}

Fonte: Oliveira et al. (2011).

Após análise dos dados expostos, observa-se alto teor de umidade, devendo ser mantido sob refrigeração e a umidade elevada a torna difícil para confecção de polpas. Possui baixo teor de proteína e os açúcares redutores lhe conferem potencial para utilização em processos industriais. Os teores de açúcar reduzido, cinzas totais (como também as cinzas solúveis e insolúveis), açúcares totais, ferro e teor de gordura encontram-se na média de trabalhos de outros autores, como apontam Oliveira e colaboradores (2011). Observa-se que, por possuir alta umidade e baixo valor proteico, não deve ser utilizada como fonte exclusiva de alimento para os rebanhos (FROTA et al., 2015).

A maioria das cactáceas possui frutos comestíveis, assim como os frutos da palma, que são ovalados, tenros e adocicados. De acordo com Nazareno et al. (2013), possuem sementes duras, em média 100-400 por fruto e são ricas em vitaminas, açúcares, aminoácidos, vitamina $C$, carotenoides, compostos antioxidantes como polifenóis e betalaínas, sendo esta última composta por pigmentos de nitrogênio e dão cores a essas frutas, bem como propriedades funcionais.

Estudos apontam que a oxidação endotelial é a porta para várias patologias sugerindo que o consumo regular destes frutos traz benefícios à saúde, com diminuição de estresse oxidativo e consequente preservação tecidual, diminuindo o risco de doenças, incluindo o câncer e doenças cardíacas (NAZARENO et al., 2013).

As sementes são ricas em lipídios e tocoferóis e, quando prensadas, produzem óleo, utilizado na confecção de cosméticos. As flores da Opuntia sp. são ricas em betalaínas, flavonóides e compostos fenólicos antioxidantes, com atividade antibacteriana, antioxidante e antifúngica, detectadas nos extratos florais (AHMED et al, 2005).

O consumo deste vegetal colabora para a redução dos níveis de colesterol total, sem alterar o nível glicêmico sanguíneo. Possui ação cicatrizante e pode ser utilizada como auxiliar no tratamento da asma, diabetes, doenças coronárias e como anti-inflamatório (PONTES et al.,2018).

A cada dia produtos naturais agroecologicamente corretos são procurados para tratamento e prevenção de doenças e alimentos funcionais e nutracêuticos podem ser produzidos a partir da palma. Os frutos e 
raquetes da palma podem ser utilizadas pelos seus princípios ativos como alimento e tratamento para diversas enfermidades. Além disso, uma grande quantidade de produtos pode ser confeccionada utilizando as raquetes ou os frutos, incluindo o uso in natura e preparos simples. Dentre eles, pode-se citar: geleias, licores, xaropes, caramelos e as raquetes como verduras. Aqui, não se pretende limitar o número de produtos que podem advir desta cactácea tão promissora.

\section{CONSIDERAÇÕES FINAIS}

A presente pesquisa apontou e reforçou os aspectos alimentares da palma forrageira, apresentando seus aspectos nutricionais e bromatológicos. Diante das variações climáticas e as secas frequentes que ocorrem no Nordeste brasileiro, levando à escassez hídrica, a palma vem destacando-se no cenário alimentício ao longo dos anos: inicialmente como vetor na indústria têxtil e, posteriormente, na alimentação animal e humana.

Utilizar estas plantas em todo o seu potencial valoriza as culturas nas quais elas se fazem presentes, salientando a importância do conhecimento, do uso e do beneficiamento de Plantas Alimentícia NãoConvencionais, como a palma forrageira, necessitando de maior atenção a essa cactácea, com o intuito de evitar a perda de conhecimento e de difusão de saberes na sociedade.

Surgindo como uma cultura estratégica na região do semiárido, a utilização da palma e de todos os seus componentes para diferentes fins, contribui para novos horizontes agroecológicos, expandindo seu uso e fortalecendo, assim, a economia local, através da agricultura familiar, possibilitando a permanência dessas populações no campo.

\section{REFERÊNCIAS}

[1] AGEITEC. Agência Embrapa de Informação e Tecnologia. Temperatura e umidade relativa. Disponível em: <http://www.agencia.cnptia.embrapa.br/gestor/bioma_caatinga/arvore/CONT000g798rt3p02wx5ok0wtedt3n17xg wk.html> Acesso em: 08 set. 2019.

[2] AHMED, M. S. et al. Antiinflammatory flavonoids from Opuntia dillenii (Ker-Gawl) Haw. flowers growing in Egypt. Phytotherapy Research: An International Journal Devoted to Pharmacological and Toxicological Evaluation of Natural Product Derivatives, v. 19, n. 9, p. 807-809, 2005.

[3] BFG - The Brazil Flora Group (2015) Growing knowledge: an overview of seed plant diversity in Brazil. Rodriguésia 66: 1085-1113

[4] FROTA, M. N. L.; CARNEIRO, M. S. S.; CARVALHO, G. M. C.; NETO, R. B. A.. Palma Forrageira na Alimentação Animal. Embrapa Meio-Norte-Documentos (INFOTECA-E), 2015.

[5] GOETTSCH B, et al. (2015) High proportion of cactus species threatened with extinction. Nature plants 1: 15142 .

[6] HUNT, D., TAYLOR, N.P.; CHARLES, G. (2006) The New Cactus Lexicon. 2 vols. DH Books, Milborne Port. 900p

[7] HUNT, D., TAYLOR, N.P.; CHARLES, G (2013) The New Cactus Lexicon, Illustrations. 2nd ed. DH Books, Milborne Port. 527p.

[8] IBGE. Instituto Brasileiro de Geografia e Estatística. Sala de Imprensa. IBGE apresenta nova área territorial brasileira: de $8.515 .767,049 \mathrm{~km}^{2}$. 2012. Disponível em: <https://agenciadenoticias.ibge.gov.br/agencia-sala-deimprensa/2013-agencia-de-noticias/releases/14318-asi-ibge-apresenta-nova-area-territorial-brasileira8515767049-km> Acesso em: 07 set. 2019.

[9] JAIMES-RONCANCIO, Mateo S.; BETANCUR, Julio; CÁMARA-LERET, Rodrigo. Palmas útiles en tres comunidades indígenas de La Pedrera, Amazonia colombiana. Caldasia, v. 40, n. 1, p. 112-128, 2018.

[10] LEUENBERGER, Beat Ernst. Interpretation and typification of Cactus ficus-indica L. and Opuntia ficus-indica (L.) Miller (Cactaceae). Taxon, v. 40, n. 4, p. 621-627, 1991.

[11] LOPES, E. B. Palma forrageira: cultivo, uso atual e perspectivas de utilização no Semiárido nordestino. João Pessoa: EMEPA-PB, 2013.

[12] MILLER, P. The Gardeners Dictionary. Londres. 1768.

[13] NAZARENO, M. A. Cactus como fuente de substancias promotoras de la salud. Laboratorio de Antioxidantes y Procesos Oxidativos.CITSE (CONICET). Facultad de Agronomía y Agroindustrias. Universidad Nacional de Santiago del Estero, Argentina. 2013. 
[14] OLIVEIRA, E. A.; JUNQUEIRA, S. F.; MASCARENHAS, R. J. Caracterização físico-quimica e nutricional do fruto da palma (Opuntia fícus indica L. mill) Ccultivada no sertão do sub-médio São Francisco. Holos, v. 3, p. 113-119, 2011.

[15] PINTO, M.S. et al. Avaliação dos aspectos físicos e químicos de brotos de palma (Opuntia sp.) para o consumo humano. Journal of Biology \& Pharmacy And Agricultural Management, v.15, n.1, jan/mar 2019.

[16] PONTES, E.D.S. et al. O Potencial Funcional da Palma Forrageira. International Juornal of Nutrology, v.11, n. S01, p.579, 2018.

[17] RANIERI, G.R.; BORGES, F.; NASCIMENTO, V.; GONÇALVES, J. R. Guia Prático de PANC - Plantas Alimentícias Não Convencionais. 1. Ed. São Paulo: Insituto Kairós, 2017.

[18] RIBEIRO-SILVA, S.; ZAPPI, D.C.; TAYLOR, N.P.; MACHADO, M.C. (2011) Plano de Ação Nacional para a conservação das Cactáceas. Série Espécies Ameaçadas no 24. Instituto Chico Mendes de Conservação da Biodiversidade (Ministério do Meio Ambiente). Brasília. Pp. 1-35.

[19] ROCHA, J. E. S. Palma forrageira no Nordeste do Brasil: o estado da arte — Sobral: Embrapa Caprinos e Ovinos, 2012. 40 p.: il. — (Documentos / Embrapa Caprinos e Ovinos, ISSN 1676-7659; 106).

[20] SUASSUNA, P. Tecnologia do Cultivo Intensivo da Palma (TCIP). Cactus Newsletter, p.51, 2013.

[21] VIGUERAS, A. L.; PORTILLO, L. 2012. Teñido de fibras con grana cochinilla y otros colorantes naturales. In: FAO. Actas de la Segunda Reunión para el Aprovechamiento Integral de la Tuna y otras Cactáceas. I Reunión Sudamericana. Argentina. p:165-175. 


\section{Capítulo 7}

As redes técnicas ambientais - Uma visão geral das dificuldades do gerenciamento de resíduos sólidos no Pontal do Paranapanema

\section{Allan Elias da Silva}

Resumo: 0 presente artigo pretende analisar as Redes Técnicas Ambientais no Pontal do Paranapanema, a partir de mapas e tabelas identificados no Inventário Estadual de Resíduos Sólidos Urbanos, publicado em 2018 pela Companhia Ambiental do Estado de São Paulo - CETESB. Tal pesquisa tem o propósito de analisar como está o gerenciamento de resíduos sólidos de tais municípios, numa visão abrangente elaborada pelo órgão. A metodologia de pesquisa adotada foi a pesquisa qualitativa com enfoque bibliográfico, onde através de questionário eletrônico estruturado, foi possível obter uma pequena sondagem de como está a atuação atual de alguns dos municípios referenciados. Foi possível concluir que ainda não há estrutura e equipe técnica que possa ser considerada satisfatória para o desenvolvimento e gestão eficientes de políticas públicas. Outro ponto relevante a se ressaltar, foi a inexistência de recursos, que pode acarretar o não investimentos nas áreas afins, imprescindíveis para a manutenção de tal Rede.

Palavras chave: Redes Técnicas Ambientais; Pontal do Paranapanema; Gerenciamento de Resíduos. 


\section{INTRODUÇÃO}

A partir dos conceitos gerais sobre Redes e apoiando no pressuposto da criação das chamadas Redes Técnicas, o presente trabalho buscou analisar uma Rede muito importante e que no momento atual do planeta, carece de gerenciamento efetivo urgente. Assim, a chamada de Rede Técnica Ambiental surge tendo papel ímpar para toda sociedade e ao meio ambiente como um todo.

Partindo desses pressupostos, foi possível adentrar em aspectos relevantes e que fazem parte da gama de responsabilidades dos poderes públicos municipais: o gerenciamento de resíduos sólidos. Nessa seara, no presente trabalho foi observado os dados extraídos do registro publicado em 2019 e com data-base 2018, do Inventário Estadual de Resíduos Sólidos da CETESB - Companhia Ambiental do Estado de São Paulo, ao qual possui periodicidade anual e possui o objetivo discriminar detalhadamente como estão as aplicações legais de premissas básicas e específicas dos municípios e seus conglomerados (regiões), no que tange ao bom gerenciamento de seus rejeitos. Desse modo, foi possível observar as grandes melhorias nos processos ao decorrer do tempo, bem como as dificuldades de alguns municípios paulistas.

Trazendo para um recorte regional, o artigo buscou observar a região do Pontal do Paranapanema, analisando os índices observados pela Companhia (como o IQR), bem como aqueles municípios que constam com situação Inadequada de gerenciamento.

\section{METODOLOGIA}

Quanto ao objetivo de estudo, utilizar-se-á a abordagem explicativa, onde segundo Gil (2006) a mesma interpreta fatos estudados, buscando identificar aspectos como, razões, fatores e causas, onde se almeja o conhecimento da realidade.

A pesquisa bibliográfica estará presente através de materiais já publicados e de notória relevância. Segundo Andrade (1998), esse tipo de pesquisa refere-se ao ambiente que se realiza ou que se a trabalha, do que a tipologia ou característica do mesmo. Assim, este trabalho acadêmico se respaldará sobre uma revisão bibliográfica, ou seja, de pesquisas já propostas.

0 método de abordagem utilizado será o qualitativo, onde se realiza as pesquisas no ambiente real, detalhando e interpretando problemas e atribuindo-lhes possíveis soluções.

Através das observações citadas e tendo como limitação de pesquisa o distanciamento social, causado pela pandemia da Sars Cov-2, foi possível como instrumento de pesquisa em campo, construir um pequeno questionário estruturado, a fim de sondagem de quais são os principais problemas encontrados pelos municípios e que limitam um controle de destinação de resíduos com maior efetividade, partindo logicamente, das diretrizes legais. Nesse diapasão, foi enviado a todos os municípios do Pontal do Paranapanema o referido questionário a fim de análise sintética dos problemas encontrados. Os resultados podem ser verificados no capítulo 3, onde se aborda através de gráficos, as respostas obtidas pelos 8 municípios participantes que responderam tais indagações, salientando que dentre eles 3 , aos quais no Inventário analisado, constava com irregularidades demonstrando uma situação de inadequação.

\section{RESULTADOS E DISCUSSÕES}

\subsection{VISÃO TERRITÓRIO E REDE}

Para estabelecer relações analíticas de território, torna-se imprescindível obter noções preestabelecidas e esclarecidas de espaço. Muitos autores da área geográfica estabelecem uma definição de espaço sintetizada e considerada simples. Para Santos (1978) expõe o espaço como um elemento proveniente de uma práxis humana conjunta:

(...) 0 espaço por suas características e por seu funcionamento, pelo que ele oferece a alguns e recusa a outros, pela seleção de localização feita entre as atividades e entre os homens, é o resultado de uma práxis coletiva que reproduz as relações sociais, (...) o espaço evolui pelo movimento da sociedade total (SANTOS, 1978, p. 171). 
Em suma, o espaço é o resultado das relações sociais vivenciadas do seu modo mais simples. A partir dessas colocações, já se pode observar os territórios e suas complexidades.

Os territórios são formados continuamente pela ação do homem, onde sua constituição provém da apropriação desse agente no espaço. Para Raffestin (1993), o homem é o autor sintagmático em qualquer base, onde o mesmo ao realizar apropriações dos espaços, realiza o fenômeno da territorialização.

A materialidade é uma característica importante para a configuração territorial, é através dos acréscimos da intervenção humana no espaço natural pré-existente. É relevante observar sua distinção já que o território provém da realidade desse adjetivo, enquanto o espaço compõe a matéria e a vida que o faz existir (SANTOS, 1996).

Santos (2001) ainda disserta que a organização espacial se demonstra por intermédio de substâncias fixas formadas a partir de um empenho social, onde através de fluxos, se obtém certa interação entre esses fixos. A partir desses chamados fixos e fluxos é onde se originam as chamadas redes.

As redes estão em todos os lugares, elas são criadas e alastradas através das relações e mecanismos criados e/ou desenvolvidos, às vezes elas existem e passam por despercebido pelo homem, porém estão ali juntamente com seus agentes sociais, que realizam a função de colocá-las em sintonia com os objetivos que as originaram.

Santos (1999) caracterizou as redes como globais e locais, onde as mesmas ao mesmo tempo que tem o poder de cobrir todo planeta, podem se adaptar de acordo com sua estrutura técnica desenvolvida.

As redes são, ao mesmo tempo, globais e locais. São globais porque cobrem todo o ecúmeno e, na verdade, constituem o principal instrumento de unificação do Planeta. Mas elas também são locais, já que cada lugar, através de sua estrutura técnica e de sua estrutura informacional, acolhe uma fração, maior ou menor, das redes globais. No lugar, elas servem ao trabalho e ao capital (vivo) e determinam a sua natureza (SANTOS, 1999, p.14).

A distinção entre território e rede deve ser evidenciada através de aspectos que as diferenciam notadamente. Haesbaert (2006), dividiu em partes esses fenômenos geográficos (relação dicotômica), observando a relação e as ideias que estabelecem alguns autores como os sociólogos Manuel Castells e Marion Joseph Lévy e o geógrafo Augustin Berque.

Quadro 1.Visão dicotômica Território-Rede de Haesbaert

\begin{tabular}{|c|c|}
\hline \multicolumn{2}{|c|}{ Visão dicotômica Território-Rede } \\
\hline TERRIÓRIO & REDE \\
\hline intrínseco (mais introvertido) & extrínseca (mais extrovertida) \\
\hline centrípeto & centrífuga \\
\hline áreas, superfícies & pontos (nó) e linhas \\
\hline delimita (limites) & desenraizamento \\
\hline enraízamento & mais instável \\
\hline mais estável & espaço reticular (circulação - Berque) \\
\hline espaço areolar ("habitação) & espaço de fluxos (Castells) \\
\hline espaço de lugares & métrica topológica, não euclidiana (J. Lévy) \\
\hline métrica geográfica &
\end{tabular}

Fonte: Haesbaert, 2006, p. 288

Como se percebe, as diferenciações entre território e rede são nítidas, onde em alguns aspectos as mesmas chegam a ter atributos de qualidade antônimas, quando comparadas. Ao analisar o território tem-se: o caráter intrínseco, onde independe de quaisquer relações; forma centrípeta, onde tende ter adjetivação centralizada; observação de existência de áreas, superfícies que os particularizam; exposição a limites ou delimitações que criam separações entre cada um; enraizamento através de certa imutabilidade; estabilidade, quando analisado pelas variações; equilíbrio; espaço de habitação, onde se define as ações de seus atores/agentes; espaço de lugares, grandes cidades, comércio; exibição de métrica geográfica que pode ser definida por intermédio de suas ferramentas, como a cartografia. 
Quando se analisa o quadro, a visão de Haesbaert (2006) para as redes tem-se: percepção extrínseca, realizando-se por intermédio de relações baseadas na exterioridade; afastamento de uma centralidade, existindo em todos os espaços; existência de nós que podem ser considerados como pontos de influência de diversas intensidades (RIBEIRO, 2001); rompimento de limites, através de fluxos; desenraizamento, ou seja, tem o poder de sair de sua origem de criação; instabilidade, com variações, dependendo de sua presença, tipo e intensidade; característica de circulação, movimento; espaço com fluxos, com grande quantidade de ações e intervenções; disposição topológica no espaço com grande conexidade.

Para Souza (2013) apud Machado (1999), o modelo de organização das redes restringe o crescimento de processos espaciais com denotação centrípeta, ou seja, das técnicas que colaboram para a centralidade de núcleos específicos e suas disposições. Essas estruturas de hierarquia, surgem quando há contato entre agrupamentos independentes, onde cada qual com sua finalidade diversa, cria um modo de organização no qual uma cidade não se subordina a outra ao qual está sobre ela.

\subsection{ATORES E AGENTES SOCIAIS}

Entender, definir e distinguir os atores e agentes sociais em quaisquer Redes, é de suma relevância para verificação de posicionamento e visualização adequada de como se dá as relações, fluxos e o funcionamento da mesma nos diversos locais de atuação. Capel (2013), faz a distinção clara entre atores e agentes:

[...] una distinción que parece útil, la de actores y agentes urbanos. Los primeros son todos los individuos y grupos sociales presentes en la ciudad, que viven y se mueven en ella; mientras que incluiremos en el segundo grupo a los que tienen capacidad para intervenir en la construcción de la ciudad. Entre los unos y los otros, y en el interior de cada grupo, pueden existir conflictos de intereses. Pero también transacciones y acuerdos (CAPEL, p. 17, 2013).

Deste modo, os atores são os indivíduos e grupos envolvidos e movimentam o ambiente, já os agentes são os seres capazes de interferir, propondo intervenções e com o poder de modificações de acordo com as políticas públicas propostas e adotadas.

As inter-relações entre agentes e atores nem sempre podem ser consideradas harmônicas, pois as responsabilidades dos primeiros, podem não expressar a vontade ou o fluxo de informação efetivo para uma totalidade: "La construcción de la ciudad es frecuentemente un proceso conflictivo, ya que pueden existir contradicciones entre los distintos agentes y entre los intereses de éstos y las actividades que se realizan" (CAPEL, p, 18, 2013).

Outro ponto relevante a se destacar, é a diferenciação dos tipos de agentes: públicos e privados. Os agentes públicos, de acordo com Capel (2013), podem almejar a melhoria da qualidade de vida e o bemestar de uma totalidade, como por exemplo, a preservação do meio ambiente; já os privados, podem almejar somente seus proveitos econômicos próprios. Esses interesses e objetivos de cada um desses agentes, podem inverter-se e envolver relações de poder e prestígio social, que têm a capacidade de junto ou separadamente, impactar nas intervenções espaciais.

\subsection{REDES TÉCNICAS AMBIENTAIS}

Dentre as tipologias de redes, há uma bastante específica que estabelece conexões entre seres técnicos no território, elas são chamadas de técnicas: "As redes técnicas são formadas por um sistema integrado de objetos técnicos (fixos no espaço) e de fluxos (matéria, serviços e informação em circulação) que criam as conexões entre os objetos técnicos no território, e que estas conexões podem ser físicas e invisíveis" (DEMANTOVA, 2009, p. 162).

Dentre a pluralidade das redes técnicas existentes, o presente trabalho vem analisar a mesma no campo ambiental, precisamente dentre de umas de suas potencialidades, que é o gerenciamento de resíduos sólidos. Essa rede é composta por uma gama de territórios e fluxos, aos quais os agentes sociais têm papel ímpar para sua existência. 
No que diz respeito à rede técnica ambiental, os objetos técnicos são todas as áreas verdes urbanas (parques ecológicos, bosques, praças, campos de futebol, jardins particulares, e outras que ofertem serviços ambientais). Com relação aos fluxos da rede técnica ambiental, estes são formados pela informação que é produzida, divulgada e apropriada pelos agentes sociais para uma participação ativa na organização espacial do seu território, materializadas nas formas de ocupação do território (DEMANTOVA, 2009, p. 162).

A Rede Técnica Ambiental tem grande relevância no cenário atual, onde grandes desequilíbrios ambientais aparecem carecendo de medidas corretivas e saneadoras urgentemente. Essa rede emerge de diversas formas, segundo Demantova (2009), o desafio na criação dessa tipologia de rede, com capacidade de promover benefícios definidos e ampliar a sustentabilidade no espaço urbano, em vertentes sociais e ambientais, está diretamente ligado ao modo de entendimentos desse espaço em sua totalidade, a fim de obter estratégias que sejam capazes de preservar com efetividade o que se torna absolutamente necessária a preservação.

\subsection{GERENCIAMENTO DE RESÍDUOS SÓLIDOS}

Internamente a essa Rede Técnica, tem-se um fator imprescindível que são as ações, práticas e políticas públicas voltadas para o Gerenciamento de Resíduos Sólidos Urbanos. Esse Gerenciamento demanda certo perfil técnico de atores/agentes sociais e procedimentos que demandam engajamento a políticas e infraestruturas específicas. "Na atualidade, as atividades de gestão e gerenciamento de resíduos sólidos que operacionalizam a rede técnica adotam técnicas e tecnologias que ainda demandam aprimoramento para garantir a produção mais limpa e a destinação segura e menos impactante" (FIORE, 2013, p. 3).

Essa tecnologia citada por Fiore (2013), muitas vezes não está ao alcance facilmente dos agentes públicos, aos quais têm papéis primordiais para instrumentalizar as políticas públicas, que devem ser aprimoradas continuamente, adequando-se às exigências fiscalizatórias e legais. O que se percebe atualmente ainda, em diversos municípios (principalmente de pequeno porte), é a falta de estrutura, profissionais e constituição de equipe que seja capaz de integrar todas as demandas ambientais envoltas ao bom gerenciamento desses resíduos.

Os processos classificados como ineficientes desse gerenciamento, podem acarretar diversos prejuízos socioambientais, em síntese, a gestão dessa rede técnica tem a necessidade de tratamento pormenorizado e especializado.

o gerenciamento de resíduos sólidos pode ser caracterizado como o conjunto de ações que visam a destinação ambientalmente adequada e segura dos resíduos. Em função das características dos resíduos sólidos que espelham o contexto político, social e econômico local, descrevem-se no território diferentes redes técnicas. Das atividades de gerenciamento, destaca-se a destinação dos resíduos sólidos, quer seja pela possibilidade de mensuração de seus impactos, quer pelos altos custos envolvidos nas soluções mais seguras. A ineficiência do manejo e a disposição inadequada dos resíduos sólidos acarretaram a existência de grandes áreas contaminadas (identificadas ou não), redes informais de catação e o aumento do impacto socioambiental que as redes técnicas de resíduos sólidos impõem ao território (FIORE, 2013, p. 3).

A Política Nacional de Resíduos Sólidos (PNRS) verificada Lei Federal 12.305/2010, pode ser considerada um grande marco do século XXI, no que se refere à normatizações relativas a Gestão Ambiental como um todo, e principalmente o gerenciamento de resíduos. Dentre suas diversas contribuições, em seu inciso XVI de seu artigo 3ํㅡㄹ definiu o que são claramente os chamados resíduos sólidos como qualquer "[...] material, substância, objeto ou bem descartado resultante de atividades humanas em sociedade, a cuja destinação final se procede, se propõe proceder ou se está obrigado a proceder, nos estados sólido ou semissólido, [...]" (BRASIL, 2010, p. 2). 
A definição acima apresentada, expõe como ação humana é responsável pela formação dos resíduos sólidos, sendo o agente responsável pelas suas destinações em sociedade. A definição da PNRS (2010) ainda vai além quando complementa sobre a destinação dos resíduos, ainda em sua definição: “[...] cujas particularidades tornem inviável seu lançamento na rede pública de esgotos ou em corpos d'água, ou exijam para isso soluções técnicas ou economicamente inviáveis, em face da melhor tecnologia disponível" (BRASIL, 2010, p. 2).

O legislador nesse caso, deixa nítido que resíduos sólidos, são aqueles cujo lançamento é inviabilizado, tendo em vista melhores soluções para sua destinação. Nesse caso, percebe-se falho tal concepção quando se diz "inviabilidade", sejam quando se descreve de suas particularidades ou melhores soluções de descarte, já que a informação desse conhecimento de "inviabilidade" envolve uma gama de conhecimentos técnicos, aos quais a população em geral ainda não absorveu com primazia, e as tecnologias disponíveis estão longe de chegar a todos os municípios do país. Outra definição, não menos importante, ao qual o presente trabalho explana, e o legislador impõe e sintetiza é o de gerenciamento de resíduos sólidos. A definição está longe de ser complexa, porém expõe a existência de um documento relevante ao qual faz dar suporte a esse gerenciamento - Plano de Gerenciamento de Resíduos.

O conjunto de ações exercidas, direta ou indiretamente, nas etapas de coleta, transporte, transbordo, tratamento e destinação final ambientalmente adequada dos resíduos sólidos e disposição final ambientalmente adequada dos rejeitos, de acordo com plano municipal de gestão integrada de resíduos sólidos ou com plano de gerenciamento de resíduos sólidos [...] (BRASIL, 2010, p. 2).

Com o intuito de análise das demandas de resíduos existe tal plano, ao qual cada ente da federação em sua esfera, tem o dever de acompanhar e realizar as medidas e ações relevantes, de acordo com suas necessidades.

No âmbito municipal, o Plano tem nomenclatura de "Plano Municipal de Gestão Integrada de Resíduos Sólidos", para outras entidades, descritas em seu Art. 20, "Plano de Gerenciamento de Resíduos Sólidos". 0 Plano Municipal de Gestão Integrada de Resíduos Sólidos, de acordo com a legislação, é um pressuposto básico para que os entes recebam recursos da União. Dentre seu conteúdo exigido, tem-se a necessidade de "I - diagnóstico da situação dos resíduos sólidos gerados no respectivo território, contendo a origem, o volume, a caracterização dos resíduos e as formas de destinação e disposição final adotadas" (BRASIL, 2010, p. 8).

É importante salientar que o diagnóstico deve compor a realidade do Ente, a fim de um cenário de Prognóstico palpável, através das medidas corretivas. A preocupação pela destinação dos resíduos sólidos está cada vez mais latente, isso ocorre pois há diversas fontes geradoras, aos quais cada qual, deve ter uma ação específica de direcionamento.

Dentre os aspectos citados por Fiore (2013), ao qual leva em consideração a Lei 12.305/2010, a chamada lei que introduziu a obrigatoriedade do Plano Nacional de Resíduos Sólidos e Plano Municipal de Gestão Integrada de Resíduos Sólidos, percebe-se que os resíduos estão em toda parte, englobando serviços públicos, rurais, de saúde, construção civil e indústria.

Trazendo essa visão de Redes Técnicas, tal como seus atores/agentes sociais e a real necessidade de busca de desenvolver-se sustentavelmente, o presente artigo buscou analisar dentro dos limites do Estado de São Paulo, a região do Pontal do Paranapanema. 


\subsection{GERENCIAMENTO DE RESÍDUOS SÓLIDOS NO PONTAL DO PARANAPANEMA}

O Pontal do Paranapanema é uma divisão regional formada por 26 municípios do interior de São Paulo. Possui aproximadamente 600 mil habitantes, tendo como maiores cidades de nível populacional Presidente Prudente, Presidente Epitácio e Presidente Venceslau.

A Companhia Ambiental do Estado de São Paulo - CETESB, em sua última elaboração do Inventário Estadual de Resíduos Sólidos publicado em 2018, trouxe de acordo com a figura abaixo, a configuração do Pontal do Paranapanema com os municípios abrangentes, apontando municípios com área em mais uma UGRHI - Unidades Hidrográficas de Gerenciamento de Recursos Hídricos do Estado de São Paulo.

Figura 1. Visão Cartográfica do Pontal do Paranapanema

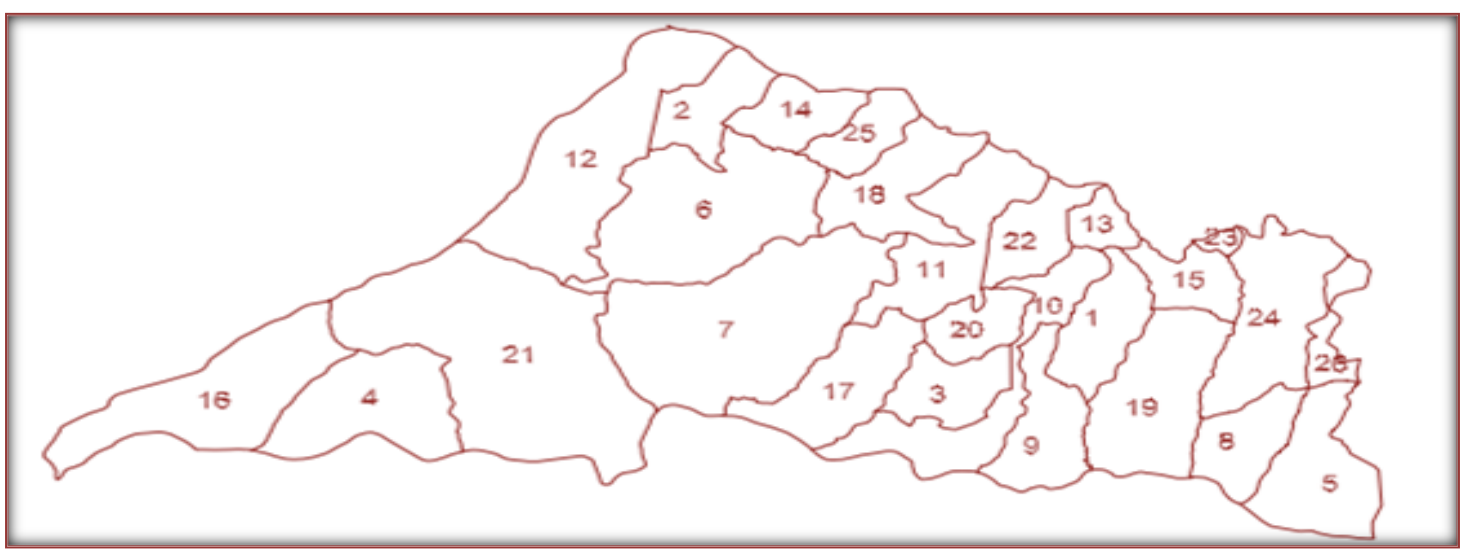

Fonte: Cetesb, 2018. Disponível em: < https://cetesb.sp.gov.br/residuossolidos/wpcontent/uploads/sites/26/2019/06/Invent\%C3\%A1rio-Estadual-de-Res\%C3\%ADduos-S\%C3\%B3lidos-Urbanos2018.pdf>. Acesso em: 04 ago. 2020

Em visão mais nítida da localização de cada município do mapa anterior, a CETESB (2018), elaborou uma tabela para referenciar suas localizações exatas, com disposição do CBH - PP - Comitê de Bacias Hidrográfica do Pontal do Paranapanema.

Quadro 2. Municípios pertencentes ao Pontal do Paranapanema

\begin{tabular}{|c|c|c|c|c|c|}
\hline \multicolumn{4}{|c|}{ CBH - PP } & \multicolumn{2}{|r|}{ OUTROS CBHS } \\
\hline 1 & Anthumas & 12 & Presidente Epitacio * & 22 & Alvares Machado ". \\
\hline 2 & Cainua * & 13 & Presidente Prudente *- & 23 & Indiana *- \\
\hline 3 & Estrela do Norte & 14 & Presidente Venceslau ${ }^{--}$ & 24 & Martinopolis -. \\
\hline 4 & Euclides da Cunha Paulista & 15 & Regente Felyb -- & 25 & Piquerobi '- \\
\hline 5 & lepe - $^{-}$ & 16 & Rosana & 26 & Rancharia * \\
\hline 6 & Marabad Paulista & 17 & Sandovalina & & \\
\hline 7 & Mirante do Paranapanema & 18 & Santo Anastácio *- & & \\
\hline 8 & Nantes & 19 & Taciba & & \\
\hline 9 & Narandiba & 20 & Tarabaí & & \\
\hline 10 & Pirapozinho & 21 & Teodoro Sampaio & & \\
\hline 11 & Presidente Bernardes *. & & & & \\
\hline
\end{tabular}

Fonte: Cetesb, 2018. Disponível em: < https://cetesb.sp.gov.br/residuossolidos/wpcontent/uploads/sites/26/2019/06/Invent\%C3\%A1rio-Estadual-de-Res\%C3\%ADduos-S\%C3\%B3lidos-Urbanos2018.pdf>. Acesso em: 04 ago. 2020 
Dentro da gama de índices para verificação de qualidade de resíduos, tem-se o IQR - Índice de Qualidade de Aterro de Resíduos, publicado anualmente nos Inventários de Resíduos Sólidos Urbanos pela CETESB. De acordo com a Coordenadoria de Planejamento Ambiental (2020), trata-se de um índice calculado deste 2009, ao qual leva em conta as respostas dos municípios no questionário do IQG - Índice de Qualidade de Gestão de Resíduos Sólidos.

No mapa a seguir, extraído do último Inventário Estadual de Resíduos Sólidos, publicado em 2018, a CETESB identificou alguns municípios do Pontal do Paranapanema que ainda consta com situação Inadequada. Ao analisar se tem 8 municípios com tal cenários são eles: Presidente Venceslau, Presidente Epitácio, Caiuá, Marabá Paulista, Mirante do Paranapanema, Sandovalina, Santo Anastácio e Euclides da Cunha Paulista.

Apesar de tais municípios ainda constarem situação irregular perante gerenciamento de seus resíduos, em comparação ao ano de 2011, percebe-se uma grande melhora na qualidade desse índice. Analisando e comparando tais anos demonstrados, extrai-se que em 2011, cerca de 89\% dos resíduos dos municípios desse recorte estavam inadequados; em 2018 tem-se uma mudança considerável, com cerca 75\% da quantidade de resíduos, tendo uma destinação considerada adequada.

Figura 2. Municípios e sua Quantidade de Resíduos - Situação Adequada e Inadequada

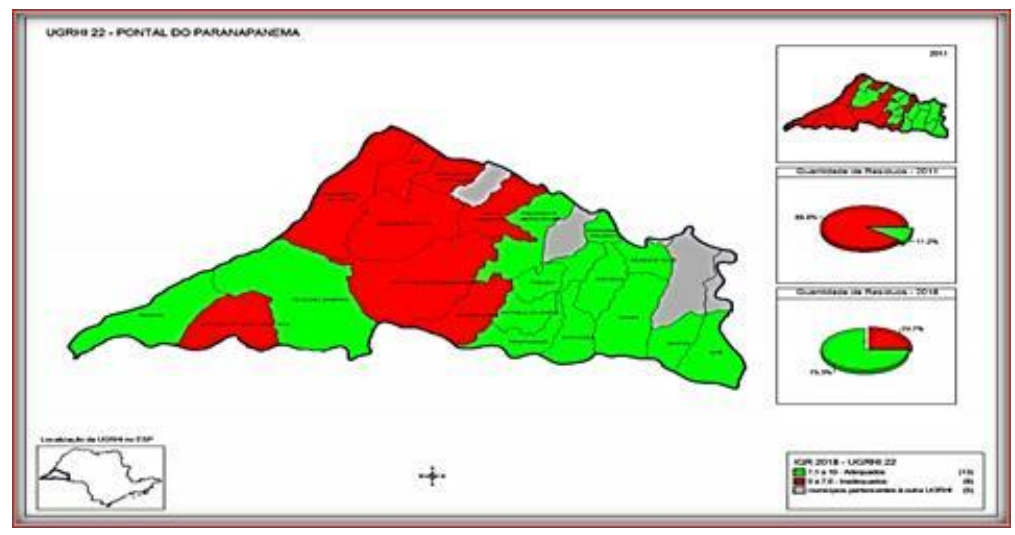

Fonte: Cetesb, 2018. Disponível em: < https://cetesb.sp.gov.br/residuossolidos/wpcontent/uploads/sites/26/2019/06/Invent\%C3\%A1rio-Estadual-de-Res\%C3\%ADduos-S\%C3\%B3lidos-Urbanos2018.pdf>. Acesso em: 04 ago. 2020

Ao observar os municípios envolvidos, é possível verificar que os municípios com status de inadequação, tiveram queda considerável de seus índices IQR, (excetuando Presidente Venceslau, ao qual subiu de 3,9 a 6,2). É possível verificar que as mesmas não possuíam Termo de Ajustamento e Conduta com o Ministério Público, utilizados comumente na promoção de ajustamento para situações consideradas irregulares. Em relação as licenças ambientais (excetuando Presidente Venceslau, ao qual possuía licença de instalação para aterro sanitário e Santo Anastácio, que possuía além dessa, a licença de operação), se tem total ausência nas demais. 


\begin{tabular}{|c|c|c|c|c|c|c|c|c|c|c|c|c|c|c|c|c|c|}
\hline \multirow{2}{*}{\multicolumn{2}{|c|}{ MUNICIPIO }} & \multirow{2}{*}{$\begin{array}{l}\text { AGÉNCI } \\
\text { AMBIENTAL }\end{array}$} & \multirow[b]{2}{*}{ RSU(vilia) } & \multicolumn{9}{|c|}{ INEENTKRIO } & \multirow{2}{*}{\multicolumn{2}{|c|}{ ENQUADRAMENTOE OBSERVAÇAO }} & \multirow[b]{2}{*}{ TAC } & \multirow[b]{2}{*}{ LI } & \multirow[b]{2}{*}{ LO } \\
\hline & & & & $\sqrt{20112}$ & 2012 & 2013: & 2014 & 2015 & 20162 & 2017 & 201 & & & & & & \\
\hline ANHUMMS & .48 & Pres. Prudente & 2,34 & 8,5 & 8,5 & 9,2 & 8.4 & 8.4 & 8.2 & 8.6 & 9.0 & & $\mathrm{~A}$ & & Sim & Sim & Sim \\
\hline$\overline{\text { CANUA }}$ & $\cdot$ & Pres. Prudenle & 1,55 & 8,5 & 7,3 & 7,3 & 7,5 & 7,5 & 7,2 & 4,7 & 4,0 & & 1 & & Năo & Năo & Naso \\
\hline ESTRELADO NORTE & ? & Pres. Prudente & 1,53 & 7,8 & 7,3 & 7,7 & 8,7 & 7,4 & 7,3 & 8,9 & 9,2 & & A & D. Quata - AP. & Năo & Sim & Sim \\
\hline EUCLIDES DA CUNHAPAULISTA & , & Pres. Prudente & 4,20 & 6,1 & 7,5 & 7,2 & 7,1 & 7,1 & 7,2 & 7,5 & 5,1 & & I & & Năo & Năo & $\mathrm{Na}$ \\
\hline IEPE & T & Pres. Prudente & 5.05 & 7,1 & 7,2 & 7,2 & 5,1 & 7,9 & 7,4 & 8.5 & 8,1 & & A & & Nằ & Sim & Sim \\
\hline MWRABAPAULISTA & $T$ & Pres. Prudente & 1,79 & 8,2 & 7,7 & 7,3 & 7,1 & 7,3 & 7,8 & 7,3 & 5,5 & & 1 & & Nă & Năo & Naso \\
\hline MRANTE DO PARANAPANEMA & 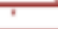 & Pres. Prudente & 7,49 & 6,8 & 6,7 & 8,2 & 7,3 & 7,2 & 7,4 & 7,6 & 5,0 & & 1 & & Nago & $\overline{\text { Ná }}$ & Naso \\
\hline NANTES & 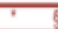 & Pres. Prudente & 1,95 & 7,5 & 7,6 & 7,2 & \begin{tabular}{|c|}
9,5 \\
\end{tabular} & 9,5 & 8,1 & 7,7 & 8,1 & & A & & Nă & Sim & sim \\
\hline NARANDIBA & $T$ & Pres. Prudenle & 2,44 & 7,1 & 8,5 & 8,5 & 7,2 & 7,4 & \begin{tabular}{|l|}
7,2 \\
\end{tabular} & 8,9 & 9,2 & & A & D-QuatálaP. & Nato & Sim & sim \\
\hline PIRAPOZINHO & + & Pres. Prudente & 20,75 & 5,3 & 4,2 & 4,2 & 2,8 & 3,6 & 3,8 & 8,9 & 9,2 & & A & D-Quata -AP. & Nato & Sim & $\operatorname{sim}$ \\
\hline PRESIDENTE BERNARDES & 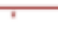 & Pres. Prudente & 7,14 & 7,1 & 7,1 & 7,1 & 9.0 & 7,2 & 7,1 & 8.6 & 7,6 & & A & & sim & Năo & Naso \\
\hline PRESIDENTE EPITACIO & ? & Pres. Prudente & 32,84 & 5,9 & 2,9 & 7,2 & 7,4 & 6,1 & 7,8 & 7,8 & 4,0 & & I & & Nă & Sim & Naso \\
\hline PRESIDENTE PRUDENTE & & Pres. Prudente & 200,20 & 3,8 & 2,7 & 2,5 & 2,7 & 5,1 & 7,1 & 7,3 & 7,5 & & A & & Nåo & Năo & $\mathrm{Nag}$ \\
\hline PRESIDENTE VENCESLAU & 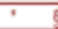 & Pres. Prudente & 30,20 & 6,2 & 6,1 & 7,1 & 8,4 & 9,4 & 7,5 & 3,9 & 6,2 & & 1 & & Năo & Sim & Naso \\
\hline REGENTE FENÓ & $\cdot$ & Pres. Prudente & 12,99 & 8,0 & 7,6 & 7,6 & 7,5 & 7,3 & 7,5 & 7,1 & 7,1 & & $A$ & & Năo & Sim & $\mathrm{Nas}$ \\
\hline ROSWNA & $T$ & Pres. Prudente & 9,59 & 5,9 & 7,3 & 7,6 & 7,2 & 7,4 & 7,0 & 7,5 & 7,4 & & $A$ & & Nat & $\overline{\mathrm{NaO}}$ & $\sqrt{\mathrm{NaO}}$ \\
\hline SANDOVLIINA & $T$ & Pres. Prudente & 2,07 & 6,9 & 6,9 & 7,4 & 7,3 & 7,2 & 7,4 & 7,8 & 6 & & 1 & & Nă & $\overline{\mathrm{NaO}}$ & $\sqrt{\mathrm{Nac}}$ \\
\hline SANTO ANASTACIO & + & Pres. Prudente & 13,63 & 6,9 & 8,5 & 7,2 & \begin{tabular}{|c|}
7,1 \\
\end{tabular} & 7,2 & 7,2 & 8,3 & 4,0 & & 1 & & Naㅇ & Sim & Sim \\
\hline TACIBA & $T$ & Pres. Prudente & 3.71 & 7,2 & 6.7 & 8,0 & 8.5 & 7,1 & 7,3 & 7,7 & 7,5 & & A & & Nato & Sim & sim \\
\hline TARABA & 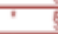 & Pres. Prudente & 4,79 & 7,7 & 8,5 & 8,0 & 7,4 & 9,0 & 8,5 & 7,3 & 8,1 & & A & & Nà & Sim & Sim \\
\hline TEODORO SAMPAO & $\%$ & Pres. Prudente & 13,08 & 6,2 & 7,2 & 7,9 & 7,5 & 7,8 & 8,3 & 9,0 & 8,5 & & A & & Nato & Sim & $\sqrt{\mathrm{NSO}}$ \\
\hline
\end{tabular}

Fonte: Cetesb, 2018. Disponível em: < https://cetesb.sp.gov.br/residuossolidos/wp-

content/uploads/sites/26/2019/06/Invent\%C3\%A1rio-Estadual-de-Res\%C3\%ADduos-S\%C3\%B3lidos-Urbanos2018.pdf>. Acesso em: 04 ago. 2020.

Portanto, no que se refere a essa importante Rede Técnica, muitos municípios carecem de medidas de destinação de seus resíduos sólidos urbanos, que podem ser considerados um grande desafio para os agentes sociais envolvidos nas políticas públicas.

Com a finalidade de obtenção de algumas respostas e sondagem da verificação dos atuais cenários de alguns municípios e a identificação de possíveis causas de suas situações fáticas atuais, foi realizado um questionário estruturado on-line, onde foi solicitado aos órgãos públicos responsáveis pela Gestão Ambiental local, o devido preenchimento, salientando que se tratava de uma pesquisa de cunho acadêmico sobre Gerenciamento de Resíduos Sólidos Urbanos.

Devido a pandemia da Sars-Cov-2, não foi possível a realização de pesquisa de campo e aplicação do questionário estruturado nos municípios de modo presencial, sendo o mesmo concretizado on-line, com a devida identificação do município prestador das informações.

\subsection{VISÃO ATUAL DE ALGUNS MUNICÍPIOS ANALISADOS}

Apesar da Companhia Ambiental do Estado de São Paulo - CETESB, já ter publicado recentemente seu novo Inventário de resíduos sólidos, o mesmo possui data-base 2019, deste modo, a fim de sondagem da situação atual dos Municípios do Pontal do Paranapanema, perante estrutura e destinação de seus resíduos sólidos urbanos, foi enviado questionário eletrônico estruturado, a todos os municípios citados, de acordo com os e-mails cadastrados em seus sítios oficiais ou Portais de Transparência. Dentre os listados, 8 responderam os questionamentos explanados, são eles: Presidente Venceslau, Caiuá, Rancharia, Indiana, Iepê, Presidente Prudente, Pirapozinho e Presidente Epitácio.

Constata-se que 100\% dos municípios em questão, possuem Plano Municipal Integrado de Resíduos Sólidos ativo e responderam que as situações das condições de tratamento de seus resíduos estão com status adequado, inclusive os municípios que no último levantamento realizado pela CETESB, constava com alguma irregularidade: Presidente Venceslau, Presidente Epitácio e Caiuá. Além disso, foi possível analisar graficamente aspectos relativos a equipe técnica e estrutura envolto a Gestão Ambiental desses 8 municípios. 
Figura 3. Equipe Mínima de Gerenciamento de Resíduos Sólidos

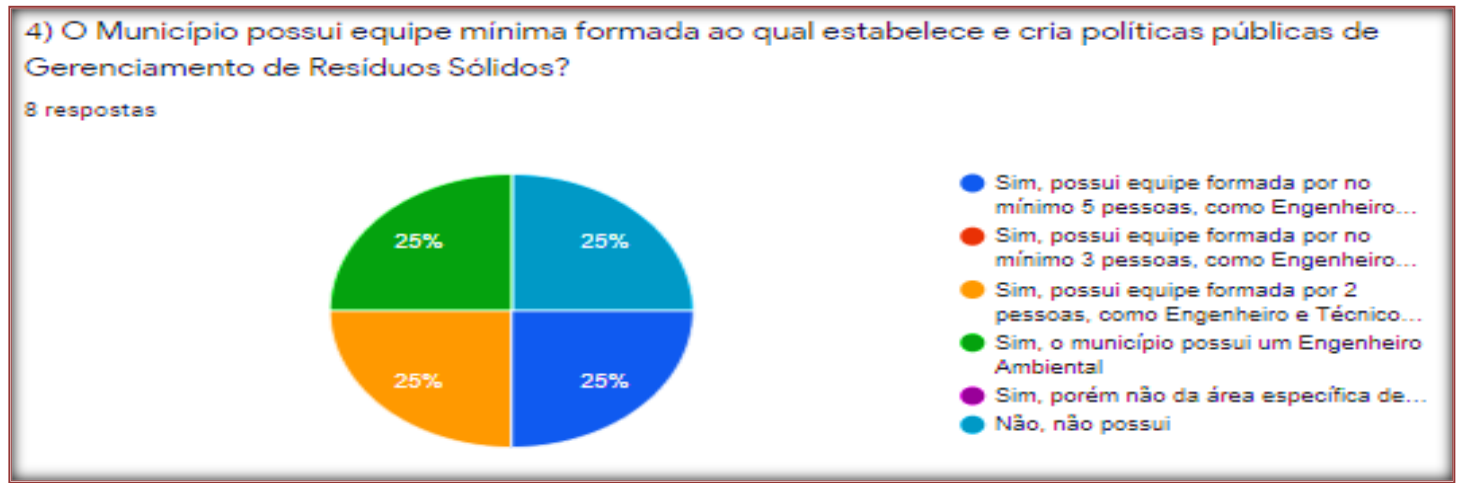

Fonte: Elaborado pelo Autor

Figura 4. Secretaria Específica de Meio Ambiente

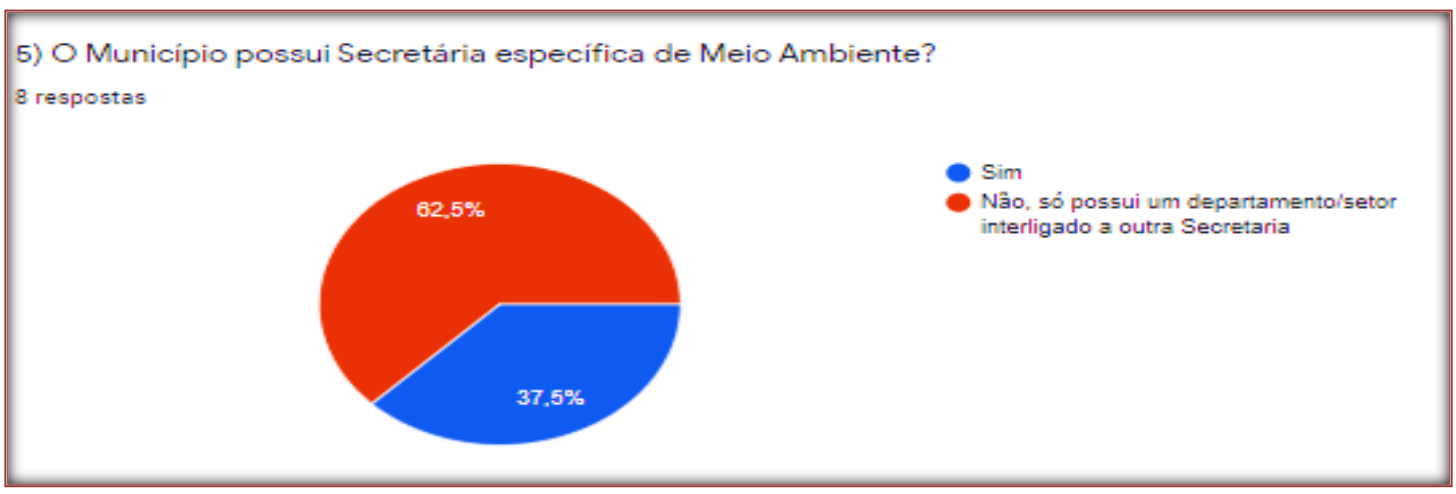

Fonte: Elaborado pelo Autor

A partir das respostas acima, é possível verificar que as equipes formadas para a Rede Técnica de Gestão Ambiental, ainda pode ser considerada insuficiente em alguns municípios, sendo constituídas, em alguns casos, somente por um profissional da área específica, como Engenheiro Ambiental. Outro ponto a salientar é a estrutura à disposição, já que 62,5\% afirmaram não possuir Secretaria específica, que trata exclusivamente de assuntos do Meio Ambiente e o consequente gerenciamento de resíduos sólidos urbanos. Essa informação, pressupõe que essa Rede Técnica pode ser considerada secundária para alguns gestores públicos locais. É relevante observar, que cerca de 37\% dos municípios não realizam a destinação de seus rejeitos de modo próprio, o que evidencia que ainda podem estar irregulares em algum aspecto ou mesmo, optaram por terceirizar tal serviço. 0 cenário observado nas licenças ambientais, indicam alguma irregularidade a ser sanada, onde $25 \%$ ainda não possuem todas aquelas exigidas pela CETESB.

Figura 5. Destinação dos Resíduos

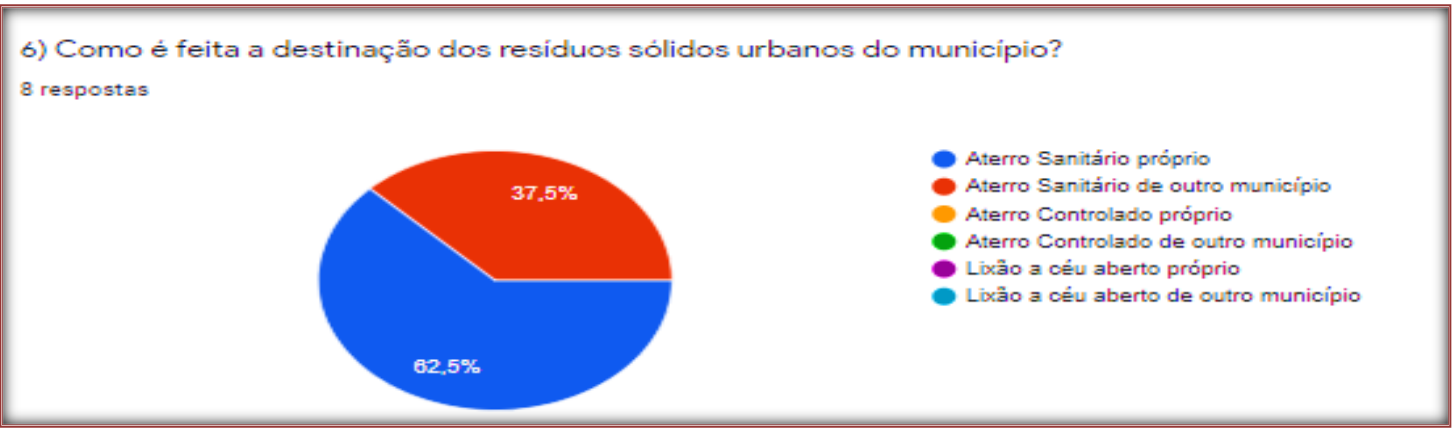

Fonte: Elaborado pelo Autor 
Figura 6. Licenças Ambientais da Cetesb

7) O Municipio possui todas as Licenças Ambientais necessárias perante a CETESB?

8 respostas

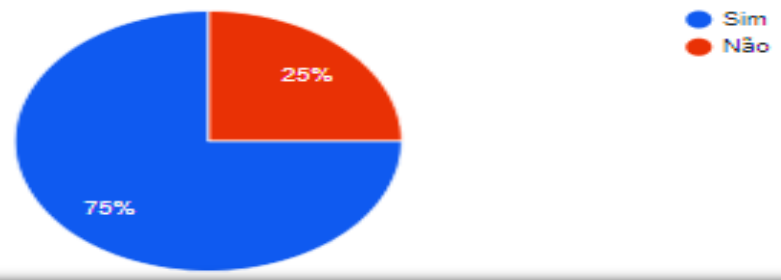

Fonte: Elaborado pelo Autor

No âmbito das legislações e fiscalizações, perante os órgãos reguladores, cerca de 50\% dos municípios, possuem alguma Ação Civil Pública, ao qual se solicita providências no que tange a adequação ao gerenciamento dos resíduos.

A tendência analisada pode ser pressuposta para os $62,5 \%$ que responderam que possuem legislação própria no que concerne Gerenciamento de Resíduos.

Figura 7. Andamento de Ações Civis Públicas

8) Há alguma(s) Ação(es) Civil(s) Pública(s) em andamento ao qual o Ministério Público (GAEMA). solicita alguma providência do municipio em relação ao Gerenciamento de Residuos Sólidos Municipal?

8 respostas

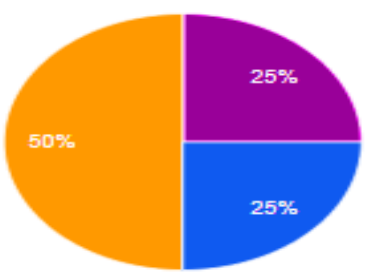

Sim, pelo menos 3 ações

Sim, pelo menos 2 açôes

Sim, pelo menos 1 ação

Nâo existe, porém já existiu, onde todas

as medidas já foram cumpridas

Nảo existe

Não sei

Fonte: Elaborado pelo Autor

Figura 8. Existência de Legislações próprias

9) O Município possui alguma legislação própria no que concerne a Gerenciamento de

Residuos?

8 respostas

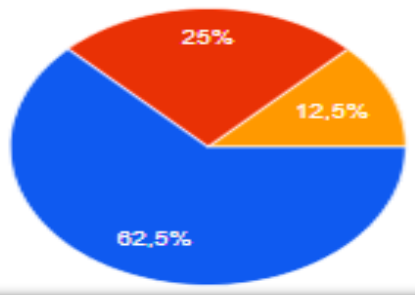


Os investimentos na área de Gerenciamento de Resíduos também foi pauta no questionário, onde 87,5\% dos entrevistados disseram que não recebem quaisquer repasses de cunho Estadual ou Federal, para gerir seus Resíduos Sólidos Urbanos. Fato que torna mais complicado o cenário, foi a resposta de 75\%, que assinalaram que o quanto o município arrecada com taxa de limpeza pública é insuficiente para implementação de políticas públicas, como incentivos aos trabalhadores da área, investimentos em equipamentos, mão de obra, manutenção de veículos e serviços diversos de funcionamento dos aterros sanitários.

Figura 9. Repasses de outras Esferas Governamentais

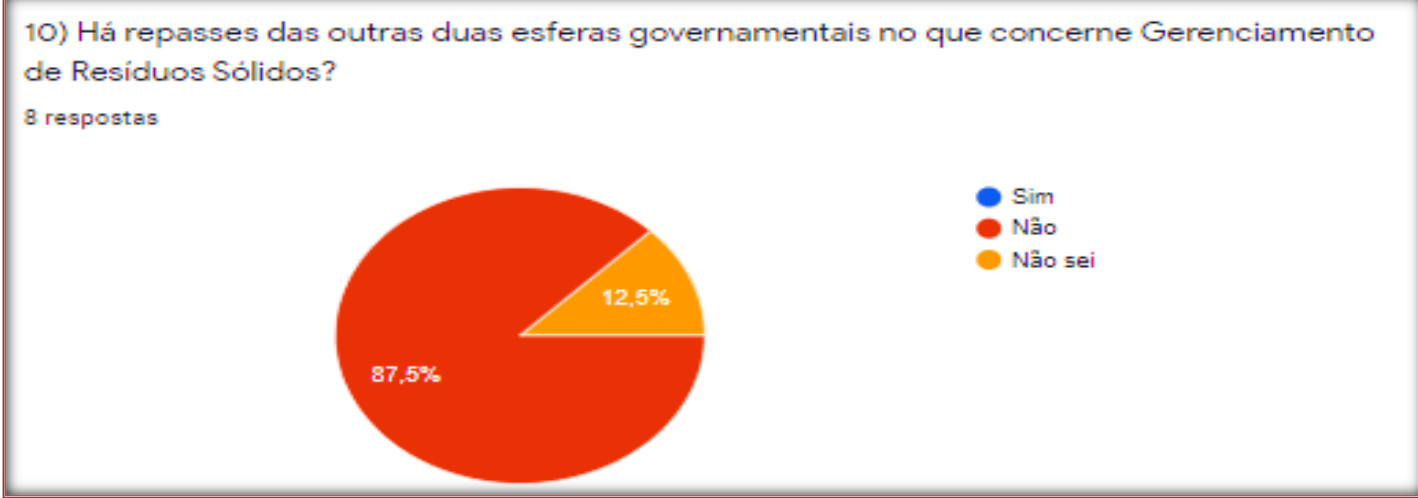

Fonte: Elaborado pelo Autor

Figura 10. Manutenção das Atividades pelas Taxas Municipais Cobradas

11) Os valores que o municipio arrecada nas taxas de limpeza pública. são suficientes para que o municipio implemente e tome as medidas necessárias para obtenção de licenças ambientais, funcionamento de aterros sanitários regularmente e manutenção dos veículos e equipamentos?

8 respostas

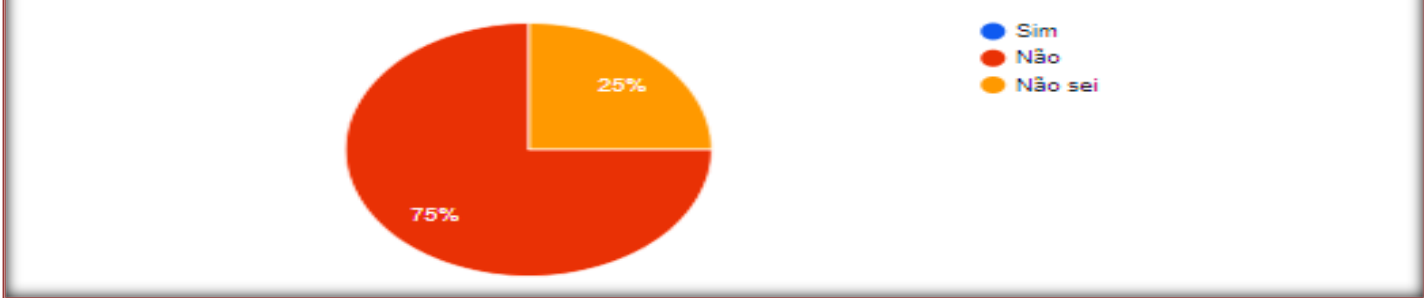

Fonte: Elaborado pelo Autor

Em suma, a pesquisa demonstra certa melhoria geral dos municípios quanto os seus Gerenciamentos de Resíduos Sólidos Urbanos, (quando comparado com o último Relatório elaborado pela CETESB), porém, percebe-se ainda, que se carece de muitas políticas públicas e investimentos nessa Rede, ao qual se faz tão relevante para o desenvolvimento sustentável da humanidade.

Os investimentos estruturais, técnicos e orçamentários, como visto através das respostas, podem ser os mais sérios a serem enfrentados pelo Setor Público, já que as políticas públicas não podem tornar-se palpáveis, se não virem acompanhadas de equipamentos, infraestrutura física, pessoal técnico habilitado efetivo e recursos financeiros para obtenção dos investimentos adequados e necessários para a área.

\section{CONSIDERAÇÕES FINAIS}

Definir, diferenciar território e redes, tal como seus atores e agentes envolvidos é primordial para poder estabelecer concreta amplitude e fluxo das atividades e importância delas para a integração das atividades e formação do espaço geográfico. As Redes Técnicas se constituem por intermédio de seres, objetivos e fluxos técnicos no território, elas são importantes e merecem uma atenção especial do administrador 
público, é o caso das Redes Técnicas Ambientais. Essas Redes englobam diversos fatores, como o gerenciamento de resíduos sólidos. $O$ ato de gerir resíduos sólidos para os municípios, pode ser considerado um grande desafio. Percebe-se atualmente que diversos órgãos de regulação estão tentando ajustar as condutas e fazer cumprir as leis ambientais, é o caso da CETESB, ao qual teve em análise, no presente artigo, seus mapas e tabelas, de acordo com o Inventário Estadual de Resíduos Sólidos, publicado em 2018.

Através dos mapas, foi possível perceber que diversos municípios do Pontal do Paranapanema, estão de modo inadequado de acordo com a gestão de seus resíduos sólidos urbanos (data-base 2018), porém a fim de analisar causas e situação atual, foi realizado pequena sondagem através de questionário estruturado on-line, onde foi possível perceber que muitos já se adequaram, mas alguns estão sobre processos de adequação de órgãos fiscalizadores, não possuem todas as licenças necessárias, não realizam serviços de destinação próprio, e estão longe de obter estrutura e equipe técnica considerável para gerir e sugerir novas políticas de gestão de seus resíduos sólidos urbanos.

0 ponto crucial analisado, (obviamente não deixando de lado às responsabilidades, os perfis e políticas ineficientes que ainda existem de modo contínuo), são as verbas públicas destinadas a esse setor, demonstrado em questionário, pode-se perceber que não existem, ou seja, os órgãos públicos não têm quaisquer meios financeiros específicos para custear essas atividades, aos quais são de suma importância para o desenvolvimento sustentável humano.

Portanto, ao analisar em conjunto sintético, é possível dizer que ainda há muito para se planejar e executar no que se refere às Redes Técnicas Ambientais, e propriamente o gerenciamento de resíduos sólidos urbanos. As políticas são necessárias, porém os investimentos devem ser exigidos para que em um todo se possa concretizar melhorias nessa área que a cada dia mais demanda atenção do ser humano.

\section{REFERÊNCIAS}

[1] ANDRADE, M. M. de. Introdução à Metodologia do Trabalho Científico: Elaboração de Trabalhos na Graduação. 4 ed. São Paulo: Atlas, 1998.

[2] BRASIL. Lei Federal no 12.305, de 2 de agosto de 2010. Institui a Política Nacional de Resíduos Sólidos; altera a Lei no 9.605, de 12 de fevereiro de 1998; e dá outras providências. Diário Oficial da União: Brasília/DF, 2010.

[3] CAPELL, H. La Morfología de las Ciudades. Ciudad de Mexico: Del Serbal, 2013.

[4] CETESB - Companhia Ambiental do Estado de São Paulo. Inventário Estadual de Resíduos Sólidos Urbanos. Disponível em: <https://cetesb.sp.gov.br/residuossolidos/wpcontent/uploads/sites/26/2019/06/Invent\%C3\%A1rio-Estadual-de-Res\%C3\%ADduos-S\%C3\%B3lidos-Urbanos2018.pdf> Acessado em 29/07/2020.

[5] COORDENADORIA DE PLANEJAMENTO AMBIENTAL - INFRAESTRUTURA E MEIO AMBIENTE. Índice de Gestão de Resíduos. Disponível em: < https://www.infraestruturameioambiente.sp.gov.br/cpla/residuossolidos/indice-de-gestao-de-residuos-

igr/\#: :text=IQR\%20\%C3\%A9\%20o\%20\%C3\%8Dndice\%20de,Estado\%20de\%20S\%C3\%A3o\%20Paulo\%20\%E2\% 80\%93\%20CETESB.>. Acessado em 06/08/2020.

[6] DEmontovA, G. C. Redes Técnicas Ambientais: Diversidade e Conexão entre Pessoas e Lugares. São Paulo: Universidade Estadual de Campinas, 2009.

[7] FIORE, F. A. A Gestão Municipal de Resíduos Sólidos por meio de Redes Técnicas. UNICAMP: São Paulo, 2013.

[8] GIL, A. C. Método e Técnicas de Pesquisa Social. $2^{\circ}$ ed. São Paulo: Atlas, 2006.

[9] HAESBAERT, R. Concepções de território para entender a desterritorialização. $2^{\circ}$ ed. Rio de Janeiro: DP\&A, 2006.

[10] RAFFESTIN, C. Por uma Geografia do Poder. São Paulo: Ática, 1993.

[11] RIBEIRO, M. A. As Redes Geográficas sob a Ótica Analítica de Miossec. N 10. Geo UERJ Revista do Departamento de Geografia, UERJ: Rio de Janeiro, 2001.

[12] SANTOS, M. Por uma Geografia Nova. São Paulo: Hucitec, 1978

[13] SANTOS, M. A Natureza do Espaço - Técnica e Tempo - Razão e Emoção. São Paulo: Hucitec, 1996.

[14] SANTOS, M. Modo de Produção Técnico-Científico e Diferenciação Espacial - Território. Ano IV, nº 6. Rio de Janeiro: Hucitec,1999. 
[15] SANTOS, M.; SILVEIRA, M. L. O Brasil: Território e sociedade no início do século XXI. Rio de Janeiro: Record, 2001.

[16] SOUZA, M. L. de. Os Conceitos Fundamentais da Pesquisa Sócio Espacial. $1^{\circ}$ ed. Rio de Janeiro: Bertrand Brasil, 2013 


\section{Capítulo 8}

Aplicação da dinâmica de sistemas na implementação de modelo computacional para estimação da qualidade do efluente de lagoas facultativas

\section{Bruna Logatti}

Erich Kellner

Resumo: 0 trabalho apresenta os resultados do desenvolvimento de modelo computacional para previsão da qualidade do efluente de lagoa facultativa proposta por FRITZ (1985) com abordagem da dinâmica de sistemas, sendo utilizado o software VenSim PLE®. 0 modelo considera o balanço de massa aplicado em reator de mistura completa, baseado na resolução simultânea de doze equações diferenciais para indicação das concentrações do efluente. A calibração ocorreu em duas etapas: verificação e validação. Os resultados obtidos para a verificação foram considerados satisfatórios, destacando-se DQO solúvel, OD e Temperatura. A validação obteve resultados para Alcalinidade, pH e DQO solúvel satisfatórios, porém para os demais parâmetros ligeiramente superiores aos observados. Tais variações podem estar associadas a não consideração da variabilidade da qualidade do afluente na lagoa facultativa, a possibilidade de ocorrência de compartimentalização do volume líquido e o fato das amostras serem pontuais.

Palavras-chave: Lagoa de estabilização, modelo computacional, qualidade do efluente, dinâmica de sistemas, VenSim PLE®, mistura completa, amostragem. 


\section{INTRODUÇÃO}

Conforme o Sistema Nacional de Informações sobre Saneamento (SNIS), 49,7\% da população brasileira não têm acesso à coleta de esgoto. Além disso, apenas $43 \%$ do esgoto do país é tratado. (BRASIL, 2017). Dados de 2016 do Instituto Brasileiro de Geografia e Estatística (IBGE) indicam que o Brasil possui 5570 municípios, dos quais 70\% apresentam menos de 20.000 habitantes (IBGE, 2016). Portanto, o Brasil é constituído de pequenos municípios que não apresentam tratamento de esgoto.

Tais dados são importantes para determinar o tipo de tratamento de esgoto a ser adotado nesses municípios. Levando-se em consideração o tamanho das cidades brasileiras, o clima apresentado pelo país e a disponibilidade de espaço e recursos para tal atividade é inevitável que as lagoas de estabilização estejam entre as opções mais viáveis para o tratamento de esgoto.

As lagoas de estabilização são um dos métodos mais simples para tratamento de efluentes. Possuem fácil construção, manutenção e operação, não necessitam de mão-de-obra especializada e equipamentos mecânicos (quando bem projetadas). São recomendadas para locais que apresentam clima tropical (altas temperaturas e incidência de raios solares), pois o tratamento é dependente de reações bioquímicas (VON SPERLING, 2007).

As lagoas de estabilização podem ser anaeróbias, facultativas ou de maturação. As lagoas facultativas são responsáveis pelo tratamento secundário do esgoto e possuem como principal característica a dualidade ambiental: aeróbia na superfície e anaeróbia no fundo (KELLNER e PIRES, 1998).

Em 1985 o cientista J. J. Fritz desenvolveu um modelo matemático capaz de simular as reações bioquímicas existentes dentro das lagoas facultativas. 0 modelo se baseia nos princípios da conservação de massas em um reator de mistura completa e consiste na resolução de 12 equações diferenciais que representam as variações temporais da biomassa ou de substâncias químicas presentes na lagoa de estabilização (FRITZ, 1985).

Esse modelo buscou estimar a concentração dos efluentes de uma lagoa facultativa, sendo eles: Substrato orgânico solúvel (DQO), Oxigênio dissolvido, Bactérias, Carbono orgânico total, Fósforo orgânico e inorgânico solúvel, Nitrogênio orgânico solúvel, Nitrogênio amoniacal, Nitrogênio - nitrato, Alcalinidade, Algas, Lodo anaeróbico (FRITZ, 1985).

No presente trabalho houve a implementação dessas equações diferenciais, utilizando a abordagem da dinâmica de sistemas, no software chamado de VenSim PLE ®. Com o modelo montado passou-se então à calibração do mesmo, separada em duas etapas sendo elas: verificação e validação.

Para cada uma dessas etapas usou-se dados distintos, para a verificação: amostras coletadas por Silva (1982) e para validação: amostras coletadas por Pedrelli (1998), destaca-se que a localização, o clima e, principalmente, o comportamento das duas lagoas facultativas eram diferentes, assim como o processo de coleta de amostras. Com a fase de simulações terminada partiu-se então para a análise dos resultados.

Os resultados mostraram-se condizentes com o esperado, para a verificação do modelo, que utilizou amostras de uma lagoa facultativa que funcionava como um reator de mistura completa, a análise pode ser tida como satisfatória, $50 \%$ dos gráficos gerados pelo modelo similares aos resultados coletados na lagoa.

Enquanto para a validação foram encontrados diversos aspectos limitantes do modelo sendo eles: a necessidade de consideração da variabilidade do afluente, a estratificação da coluna líquida, necessidade de amostras compostas e do funcionamento da lagoa ser como de uma mistura completa.

A aplicação da dinâmica de sistemas permite, de certa maneira, visualizar as relações e interações entre as várias variáveis envolvidas no processo de tratamento de esgotos por lagoas de estabilização em especial, as lagoas facultativas. A possibilidade de previsão da qualidade do efluente dessas unidades facilita a análise projetual pelo projetista, assim como a visualização da variação das principais características do efluente.

Este trabalho se justifica pela abordagem sistêmica do processo de tratamento ao se empregar a dinâmica de sistemas, assim como por permitir, com certa eficácia, a estimação da qualidade do efluente final de lagoas facultativas. 


\section{OBJETIVOS}

O objetivo principal deste trabalho foi o de desenvolver um modelo computacional no software VenSim ${ }^{\circledR}$ capaz de simular as reações bioquímicas e as iterações que ocorrem nas lagoas facultativas a partir do modelo matemático proposto por Fritz (1985). Seu objetivo secundário foi o de analisar a calibração do modelo através de duas etapas: a verificação e a validação, para cada etapa usou-se uma simulação computacional diferente e os resultados obtidos nas simulações eram comparados com amostras coletadas em lagoas facultativas.

\section{METODOLOGIA}

\subsection{MODELO DE FRITZ}

A técnica básica do modelo matemático de Fritz é a de desenvolver simultaneamente diversas equações de conservação de massa para as várias espécies bioquímicas, essas foram solucionadas via métodos numéricos em um computador. As equações de conservação de massa desenvolveram-se para espécies químicas e biomassa reagindo a fatores ambientais que afetam os mecanismos dos processos. Para essas equações dispõem-se as concentrações dos afluentes e efluentes, sendo eles: DQO, oxigênio dissolvido, bactérias, algas, carbono inorgânico, fósforo orgânico e inorgânico, nitrogênio orgânico, amônia, nitrato, alcalinidade e formação de lodo (Tabela 1) (FRITZ, 1985).

Em reatores biológicos de fluxo contínuo para um balanço completo da massa é necessário incluir termos de produção ou consumo de substâncias, afluente, efluente e acúmulo ou depleção do material (KELLNER e PIRES, 1998). Para o modelo de Fritz as simulações das características das lagoas facultativas são uma função do tempo, portanto estão sujeitas a fatores físicos e ambientais específicos do local para o período de tempo selecionado (dia ou mês). As taxas de reações (Tabela 2) que são responsáveis pelo equilíbrio entre os balanços das concentrações, também são dependentes desses fatores ambientais. (FRITZ, 1985).

Tabela 1 - Equações de Conservação de Massa para Modelo de Fritz (1985).

\begin{tabular}{|c|c|c|}
\hline Tipo & Equação & \\
\hline $\begin{array}{l}\text { Demanda Química de Oxigênio - DQO } \\
\text { (mg/l) }\end{array}$ & $\frac{d S}{d t}=\frac{S i S}{\theta}-\frac{S}{\theta}+r S$ & (1) \\
\hline $\begin{array}{l}\text { Concentração da Biomassa Bacteriana - } \\
\mathrm{Xb}(\mathrm{mg} / \mathrm{l})\end{array}$ & $\frac{d X_{b}}{d t}=\frac{X_{b i}}{\theta}-\frac{X_{b}}{\theta}+r x_{b 1}+r x_{b 2}$ & (2) \\
\hline Concentração de Algas $\quad$ - Xa (mg/l) & $\frac{d X_{a}}{d t}=\frac{X_{a i}}{\theta}-\frac{X_{a}}{\theta}+r x_{a 1}+r x_{a 2}$ & (3) \\
\hline Concentração de Oxigênio $\quad-\mathrm{O}_{2}(\mathrm{mg} / \mathrm{l})$ & $\frac{d O_{2}}{d t}=\frac{O_{2 i}}{\theta}-\frac{O_{2}}{\theta}+r 1_{d o}+r 2_{d o}+r 3_{d o}+r 4_{d o}$ & (4) \\
\hline $\begin{array}{l}\text { Concentração Nitrogênio Orgânico - No } \\
\text { (mg/l) }\end{array}$ & $\frac{d N_{o}}{d t}=\frac{N_{o i}}{\theta}-\frac{N_{o}}{\theta}+r 1_{n o}+r 2_{n o}$ & (5) \\
\hline Concentração de Amônia $\quad-\mathrm{NH}_{4}(\mathrm{mg} / \mathrm{l})$ & $\begin{array}{c}\frac{d N H_{4}}{d t}=\frac{N H_{4 i}}{\theta}-\frac{N H_{4}}{\theta}+r 1_{a m}+p 1 r 2_{a m}+r 3_{a m} \\
+r 4_{a m}\end{array}$ & $(6)$ \\
\hline Concentração de Nitrato $-\mathrm{NO}_{3}(\mathrm{mg} / \mathrm{l})$ & $\frac{d N O_{3}}{d t}=\frac{N O_{3 i}}{\theta}-\frac{N O_{3}}{\theta}+r_{1 n a}+p 2 r_{2 n a}$ & (7) \\
\hline $\begin{array}{l}\text { Concentração Fósforo Orgânico - Po } \\
(\mathrm{mg} / \mathrm{l})\end{array}$ & $\frac{d P_{o}}{d t}=\frac{P_{o i}}{\theta}-\frac{P_{o}}{\theta}+r_{1 o p}+r_{2 o p}$ & (8) \\
\hline $\begin{array}{l}\text { Concentração Fósforo Inorgânico - Pi } \\
\text { (mg/l) }\end{array}$ & $\frac{d P_{i}}{d t}=\frac{P_{i i}}{\theta}-\frac{P_{i}}{\theta}+r_{1 i p}+r_{2 i p}+r_{3 i p}$ & (9) \\
\hline $\begin{array}{l}\text { Concentração de Carbono Inorgânico } \\
\text { Total - Ct (mg/l) }\end{array}$ & $\frac{d C_{t}}{d t}=\frac{C_{t i}}{\theta}-\frac{C_{t}}{\theta}+r_{1 c t}+r_{2 c t}+r_{3 c t}+r_{4 c t}$ & $(10)$ \\
\hline - ALK (mg/l) & $\frac{d A L K}{d t}=\frac{A L K i}{\theta}-\frac{A L K}{\theta}+r 1 a$ & $(11)$ \\
\hline Lodo Gerado & $\frac{d D m}{d t}=r_{1 d}+r_{2 d}$ & $(12)$ \\
\hline
\end{tabular}

Fonte: Adaptado de FRITZ (1985). 
Tabela 2 - Taxas de Reação para Balanço da Massa.

\begin{tabular}{|c|c|c|}
\hline \multicolumn{3}{|l|}{$\begin{array}{c}\text { Reação } \\
\text { Crescimento Bacteriano }\end{array}$} \\
\hline Utilização da DQO degradável & $r s=-k * X b \cdot\left[\frac{S}{K s+S}\right] *\left[\frac{O_{2}}{K O_{2}+O_{2}}\right] *\left[\frac{N_{i}}{K b_{N}+N_{i}}\right] *\left[\frac{P i}{K b_{P}+P i}\right]$ & $(13)$ \\
\hline Crescimento das bactérias & $r x b 1=-Y * r s-k b * X b$ & $(14)$ \\
\hline Sedimentação & $r x b 2=-s b * X b$ & (15) \\
\hline \multicolumn{3}{|l|}{ Crescimento de Algas } \\
\hline Crescimento de algas & $\begin{aligned} r x a 1=X a *\{\mu a * & f(L) * f(T) *\left[\frac{C_{2}}{K C O_{2}+C O_{2}}\right] *\left[\frac{N_{i}}{K a_{N}+N_{i}}\right] *\left[\frac{P i}{K a_{P}+P i}\right] \\
& -k a\}\end{aligned}$ & $(16)$ \\
\hline Sedimentação & $r x a 2=-s a * X a$ & $(17)$ \\
\hline \multicolumn{3}{|l|}{ Geração e Utilização de Oxigênio } \\
\hline Transferência interfacial & $r 1 o d=\frac{A}{V} * K 1 O_{2} *\left(O_{s a t}-O_{2}\right)$ & $(18)$ \\
\hline Fotossíntese & $r 2 o d=1,244 * r x a 1$ & (19) \\
\hline Decaimento bacteriano & $r 3 o d=-[(1-1,42 * Y) *(-r s)+1,42 * k b * X b]$ & $(20)$ \\
\hline Nitrificação & $r 4 o d=-4,57 * r 3 a m$ & $(21)$ \\
\hline \multicolumn{3}{|l|}{ Alcalinidade } \\
\hline Nitrificação & $r 1 a=-7,14 * r 3 a m$ & $(22)$ \\
\hline \multicolumn{3}{|l|}{ Nitrogênio Orgânico } \\
\hline $\begin{array}{l}\text { Decaimento de bactérias e } \\
\text { algas }\end{array}$ & $r 1$ no $=0,124 * k b * X b+0,063 * k a * X a$ & $(23)$ \\
\hline $\begin{array}{l}\text { Transformação do N- } \\
\text { Orgânico em NH3 }\end{array}$ & $r 2 n o=-\alpha_{N} * N_{O}$ & $(24)$ \\
\hline \multicolumn{3}{|l|}{ Amônia } \\
\hline $\begin{array}{l}\text { Transformação do N- } \\
\text { Orgânico em NH3 }\end{array}$ & $r 1 a m=-r 2 n o$ & $(25)$ \\
\hline $\begin{array}{l}\text { Crescimento de algas e } \\
\text { bactérias }\end{array}$ & $r 2 a m=0,063 *(r x a 1+k a * X a)-0,124 *(-Y * r s)$ & $(26)$ \\
\hline Nitrificação & $r 3 a m=-\frac{\mu_{N}}{Y_{N}} *\left[\frac{N H_{4}}{K_{N}+N H_{4}}\right] *\left[\frac{O_{2}}{K N O_{2}+O_{2}}\right] *[C p H] *\left[C_{T}\right]$ & $(27)$ \\
\hline Regeneração bêntica & $r 4 a m=\frac{R_{N}}{h}$ & $(28)$ \\
\hline \multicolumn{3}{|l|}{ Nitrato } \\
\hline Nitrificação & $r 1 n a=r 3 a m$ & $(29)$ \\
\hline $\begin{array}{l}\text { Crescimento de algas e } \\
\text { bactérias }\end{array}$ & $r 2 n a=r 2 a m$ & $(30)$ \\
\hline \multicolumn{3}{|l|}{ Fósforo Orgânico } \\
\hline $\begin{array}{l}\text { Decaimento de algas e } \\
\text { bactérias }\end{array}$ & $r 1 o p=0,009 * k a * X a+0,024 * k b * X b$ & $(31)$ \\
\hline $\begin{array}{l}\text { Transformação do P-orgânico } \\
\text { em P-inorgânico }\end{array}$ & $r 2 o p=-\alpha_{P} * P_{O}$ & $(32)$ \\
\hline \multicolumn{3}{|l|}{ Fósforo Inorgânico } \\
\hline $\begin{array}{l}\text { Crescimento de algas e } \\
\text { bactérias }\end{array}$ & $r 1 i p=0,009 *(r x a 1+k a * X a)-0,024 *(-Y * r s)$ & $(33)$ \\
\hline $\begin{array}{l}\text { Transformação do P-orgânico } \\
\text { em P-inorgânico }\end{array}$ & $r 2 i p=r 2 o p$ & $(34)$ \\
\hline Regeneração bêntica & $r 3 i p=\frac{R_{P}}{h}$ & $(35)$ \\
\hline
\end{tabular}


(Continuação)

Tabela 2 - Taxas de Reação para Balanço da Massa.

\begin{tabular}{|c|c|c|}
\hline $\begin{array}{c}\text { Reação } \\
\text { Geração e Utilização do Ca }\end{array}$ & \multicolumn{2}{|l|}{ Taxa de Reação Volumétrica } \\
\hline Transferência interfacial & $r 1 c t=\frac{12}{44} * \frac{A}{V} * K 1 C O_{2} *\left(C_{2 s a t}-C_{2}\right)$ & $(36)$ \\
\hline Decaimento bacteriano & $r 2 c t=\frac{12}{32} * r 3 o d$ & $(37)$ \\
\hline Fotossíntese & $r 3 c t=-1,314 * r x a 1$ & (38) \\
\hline Decaimento bentônico & $r 4 c t=\frac{R_{C} * C_{M}}{h}$ & $(39)$ \\
\hline \multicolumn{3}{|c|}{ Lodo Anaeróbio } \\
\hline Sedimentação & $r 1 d=\frac{1}{h} *(s a * X a+s b * X b)$ & $(40)$ \\
\hline Ressuspensão & $r 2 d=U r * D$ & $(41)$ \\
\hline
\end{tabular}

Fonte: FRITZ (1985, p. 193).

\subsection{MODELO COMPUTACIONAL: VENSIM PLE ${ }^{\circledR}$}

0 modelo matemático de Fritz pode ser descrito como um conjunto de equações diferenciais que para serem resolvidas analiticamente necessitarão de demasiado tempo e conhecimento. Portanto, para se obter uma solução é necessário um meio de discretizar as equações e tentar aproximá-las de um sistema de equações algébricas e o uso de um modelo computacional torna-se necessário (FERZIGER, PERIC, 2002).

0 modelo matemático de Fritz necessitava de uma plataforma que permitisse: iterações dinâmicas; retroalimentação; resolução de equações diferenciais interdependentes; geração de gráficos; e, variáveis de entrada dependentes de variáveis de saída.

Tendo em vista essas necessidades o Software VenSim PLE® foi o escolhido para o desenvolvimento do modelo, já que cumpria esses requisitos com o adicional de possuir uma interface com o usuário de fácil compreensão e desenvolvimento. Elaborado pela Ventana Systems, Inc., o software tem como principal objetivo melhorar o desempenho de sistemas reais. Devendo ser usado para desenvolver, analisar e empacotar modelos de feedback dinâmico. O Vensim PLE® (Personal Learning Edition) tem como função introduzir o usuário ao sistema de modelos dinâmicos, ele é gratuito para o uso educacional e acadêmico.

\subsection{VERIFICAÇÃO DO MODELO}

A fim de verificar o modelo desenvolvido, necessita-se que o mesmo seja testado diante de dados reais obtidos em uma lagoa facultativa. Para isso, utilizaram-se dados coletados no trabalho de Silva (1982).

A verificação é definida como a resposta da pergunta: "Será que o modelo foi desenvolvido corretamente?". Portanto, ela busca retirar e corrigir os defeitos (bugs) do modelo, assim como se tiram os defeitos de programas (CHWIF e MEDINA, 2006).

A verificação do modelo desenvolvido foi feita a partir dos resultados experimentais obtidos por Silva (1982) para uma lagoa facultativa (LF5), em escala piloto, localizada em Campina Grande (PB), latitude 7,2으; longitude 35,8817으; altitude $551 \mathrm{~m}$.

A lagoa facultativa estudada possuía dimensões em planta com comprimento de 25,70 m, largura de 7,30, totalizando área de $188 \mathrm{~m}^{2}$, e profundidade de $1,25 \mathrm{~m}$ resultando em volume líquido de $235 \mathrm{~m}^{3}$.

0 experimento conduzido por Silva (1982) foi realizado entre Junho de 1979 o Novembro de 1980, e nesse período a lagoa facultativa operou com carregamento orgânico superficial ( $\lambda \mathrm{s}$ ) de $200 \mathrm{kgDBO5} / \mathrm{ha}$.dia e tempo de detenção hidráulica teórico de 18,9 dias. Durante o período analisado, a lagoa facultativa recebeu os efluentes de uma lagoa anaeróbia, cujos parâmetros qualitativos considerados estão apresentados na Tabela 3 . 
Tabela 3 - Parâmetros do afluente da (LF5)

\begin{tabular}{|l|c|c|}
\hline \multicolumn{1}{|c|}{ Parâmetro } & Valor médio & Unidade \\
\hline DQO - Si(i) & 162 & $\mathrm{mgO}_{2} / \mathrm{l}$ \\
\hline Alcalinidade - ALK & 316 & $\mathrm{mgCaCO}_{3} / \mathrm{l}$ \\
\hline Fósforo Orgânico - Po(i) & 2,95 & $\mathrm{mg} / \mathrm{l}$ \\
\hline Nitrogênio Orgânico - No(i) & 8,48 & $\mathrm{mg} / \mathrm{l}$ \\
\hline Nitrato - $\mathrm{NO}_{3}(\mathrm{i})$ & 0,3 & $\mathrm{mg} / \mathrm{l}$ \\
\hline $\mathrm{N}-$ Amoniacal - $\mathrm{NH}_{4}(\mathrm{i})$ & 31 & $\mathrm{mg} / \mathrm{l}$ \\
\hline Fósforo Inorgânico - Pi(i) & 1,05 & $\mathrm{mg} / \mathrm{l}$ \\
\hline Oxigênio Dissolvido - $\mathrm{O}_{2}(\mathrm{i})$ & 0 & $\mathrm{mg} / \mathrm{l}$ \\
\hline Carbono Inorgânico Total - Ct(i) & 60 & $\mathrm{mg} / \mathrm{l}$ \\
\hline \multicolumn{2}{|r|}{ Fonte: Silva (1982). }
\end{tabular}

No período analisado as amostras foram coletadas semanalmente, para cada dia de amostragem foram coletadas amostras a cada 2 horas, sendo então composta uma amostra diária. Ao todo foram consideradas 72 amostras compostas. Os resultados obtidos para os parâmetros analisados das amostras compostas do efluente da lagoa facultativa analisados por Silva (1982) estão apresentados na Tabela 4.

Tabela 4 - Parâmetros das amostras compostas do efluente da lagoa facultativa analisada por Silva (1982).

\begin{tabular}{|c|c|c|c|}
\hline Parâmetro & Unidade & Valor Médio & Faixa de Valores \\
\hline Temperatura & ${ }^{\circ} \mathrm{C}$ & 25,2 & $24,2-26,2$ \\
\hline $\mathrm{pH}$ & - & 7,80 & $7,63-8,05$ \\
\hline Alcalinidade & $\mathrm{mgCaCO}_{3} / \mathrm{l}$ & 316 & $275-351$ \\
\hline Fósforo Total & $\mathrm{mgPO}_{4}{ }^{-2} / \mathrm{l}$ & 4,47 & $3,88-5,22$ \\
\hline Oxigênio Dissolvido & $\mathrm{mgO}_{2} / \mathrm{l}$ & 6,1 & $2,3-9,1$ \\
\hline DQO solúvel - S & $\mathrm{mg} / \mathrm{l}$ & 16 & $10-20$ \\
\hline N-Amoniacal & $\mathrm{mg} / \mathrm{l}$ & 25,4 & $14,8-29,8$ \\
\hline
\end{tabular}

Fonte: Silva (1982).

Concomitantemente a coleta das amostras para análise qualitativa Silva (1982) procedeu a um ensaio hidrodinâmico da lagoa facultativa estudada. Para tanto, o pesquisador lançou um pulso único com traçador, na entrada da lagoa, sendo usado $\mathrm{CuSO}_{4}$ como material traçante.

A partir das concentrações do sal presente na solução traçante e no efluente da lagoa, foi construída a curva de distribuição da concentração efluente $\mathrm{x}$ tempo. Esse experimento específico foi conduzido pro 3 vezes o TDH teórico (19 dias), ou seja, 57 dias.

O centro da massa da curva de saída obtida indicou o TDH real de 9,56 dias, com número de dispersão de 0,79. A relação entre TDH real/TDH teórico foi de, aproximadamente 0,5 , o qual segundo Kellner e Pires (1998) pode representar a relação volume útil/volume físico da lagoa.

Os demais parâmetros cinéticos empregados no processo de calibração do modelo estão apresentados na Tabela 5. 
Tabela 5 - Valores dos coeficientes cinéticos utilizados na verificação.

\begin{tabular}{|c|c|c|c|c|}
\hline Coeficiente & Nome do Coeficiente & Valor & Unidade & Fonte \\
\hline Y & $\begin{array}{l}\text { Coeficiente de produção } \\
\text { carbonácea }\end{array}$ & 0,4 & $\begin{array}{l}\mathrm{mg} \mathrm{VSS} / \mathrm{mg} \\
\mathrm{bsDQO}\end{array}$ & pg. 585 (METCALF \& EDDY, 2003) \\
\hline K20 & $\begin{array}{l}\text { Taxa de máxima utilização do } \\
\text { substrato para } 20^{\circ} \mathrm{C}\end{array}$ & 5 & dia $^{-1}$ & pg. 585 (METCALF \& EDDY, 2003) \\
\hline Ks & $\begin{array}{l}\text { Constante de meia saturação do } \\
\text { Substrato }\end{array}$ & 40 & $\mathrm{mg} / \mathrm{l} \mathrm{bsDQO}$ & pg. 585 (METCALF \& EDDY, 2003) \\
\hline $\mathrm{Kb} 20$ & $\begin{array}{l}\text { Coeficiente de decaimento } \\
\text { bacteriano }\end{array}$ & 0,35 & $\operatorname{dia}^{-1}$ & pg. 29 (VON SPERLING, 2007) \\
\hline $\mathrm{KO}_{2}$ & $\begin{array}{l}\text { Constante de meia saturação do } \\
\mathrm{O}_{2}\end{array}$ & 1,1 & $\mathrm{mg} / \mathrm{l}$ & pg. 434 (MARA, HORAN, 2003) \\
\hline Kbn & $\begin{array}{l}\text { Coeficiente de meia saturação N- } \\
\text { bacterial }\end{array}$ & 0,01 & $\mathrm{mg} / \mathrm{l}$ & pg. 212 (FRITZ, 1985) \\
\hline $\mathrm{Kbp}$ & $\begin{array}{l}\text { Constante de meia saturação } \\
\text { para P-bacterial }\end{array}$ & 0,01 & $\mathrm{mg} / \mathrm{l}$ & pg. 212 (FRITZ, 1985) \\
\hline$\beta$ & Constante de Arrhenius & 1,07 & - & pg. 30 (VON SPERLING, 2007) \\
\hline $\mathrm{sb}$ & $\begin{array}{l}\text { Taxa de sedimentação } \\
\text { bacteriana }\end{array}$ & 0,05 & $\operatorname{dia}^{-1}$ & $\begin{array}{c}\text { pg.212 (CANALE, } 1976 \text { apud FRITZ, } \\
\text { 1985) }\end{array}$ \\
\hline$\mu \mathrm{a}$ & $\begin{array}{l}\text { Taxa de máximo crescimento } \\
\text { algal }\end{array}$ & 2,0 & $\operatorname{dia}^{-1}$ & $\begin{array}{c}\text { pg.212 (CANALE, } 1976 \text { apud FRITZ, } \\
\text { 1985) }\end{array}$ \\
\hline $\mathrm{KCO}_{2}$ & $\begin{array}{l}\text { Constante de meia saturação do } \\
\mathrm{CO}_{2}\end{array}$ & 1,0 & $\mathrm{mg} / \mathrm{l}$ & $\begin{array}{c}\text { pg.212 (GOLDMAN, } 1974 \text { apud FRITZ, } \\
1985 \text { ) }\end{array}$ \\
\hline Kan & $\begin{array}{l}\text { Constante de meia saturação } \\
\text { para o } \mathrm{N}_{2} \text { algal }\end{array}$ & 0,10 & $\mathrm{mg} / \mathrm{l}$ & $\begin{array}{c}\text { pg.212 (CANALE, } 1976 \text { apud FRITZ, } \\
\text { 1985) }\end{array}$ \\
\hline Kap & $\begin{array}{l}\text { Constante de meia saturação } \\
\text { para P-algal }\end{array}$ & 0,02 & $\mathrm{mg} / \mathrm{l}$ & $\begin{array}{c}\text { pg.212 (CANALE, } 1976 \text { apud FRITZ, } \\
\text { 1985) }\end{array}$ \\
\hline Ка & Coeficiente de respiração algal & 0,02 & $\operatorname{dia}^{-1}$ & $\begin{array}{c}\text { pg.212 (DITORO, } 1970 \text { apud FRITZ, } \\
1985 \text { ) }\end{array}$ \\
\hline$\alpha \mathrm{N}$ & $\begin{array}{l}\text { Taxa de transformação do } \\
\text { Nitrogênio orgânico }\end{array}$ & 0,08 & $\operatorname{dia}^{-1}$ & $\begin{array}{c}\text { pg.212 (DITORO, } 1970 \text { apud FRITZ, } \\
\text { 1985) }\end{array}$ \\
\hline$\mu \mathrm{N}$ & $\begin{array}{l}\text { Taxa de crescimento das } \\
\text { Nitrosomonas }\end{array}$ & 0,008 & $\operatorname{dia}^{-1}$ & pg. 215 (FRITZ, 1985) \\
\hline Yn & $\begin{array}{l}\text { Coeficiente de produção de } \\
\text { Nitrosomonas }\end{array}$ & 0,15 & $\mathrm{mg} / \mathrm{mg}$ & pg. 213 (FRITZ, 1985) \\
\hline$\alpha p$ & $\begin{array}{l}\text { Taxa de transferência para } \\
\text { Fósforo orgânico }\end{array}$ & 0,02 & $\operatorname{dia}^{-1}$ & $\begin{array}{c}\text { pg.217 (DITORO, } 1970 \text { apud FRITZ, } \\
1985 \text { ) }\end{array}$ \\
\hline $\mathrm{Cm}$ & $\begin{array}{l}\text { Taxa dióxido de } \\
\text { carbono/carbono }\end{array}$ & 0,5 & - & pg. 213 (FRITZ, 1985) \\
\hline sa & Taxa de sedimentação algal & 0,05 & $\operatorname{dia}^{-1}$ & $\begin{array}{c}\text { pg.212 (CANALE, 1976 apud FRITZ, } \\
\text { 1985) }\end{array}$ \\
\hline Ur20 & $\begin{array}{l}\text { Taxa de regeneração bêntica } \\
\text { para } 20^{\circ} \mathrm{C}\end{array}$ & 0,09 & $\operatorname{dia}^{-1}$ & $\begin{array}{c}\text { pg.212 (FOREE, 1970 apud FRITZ, } \\
\text { 1985) }\end{array}$ \\
\hline
\end{tabular}

\subsection{VALIDAÇÃO DO MODELO}

A fim de analisar a validade do modelo desenvolvido, necessita-se que o mesmo seja testado diante de dados reais obtidos em uma lagoa facultativa. Para isso, utilizaram-se dados coletados na dissertação de mestrado de Pedrelli (1997). No entanto, destaca-se que nem todos os dados necessários para o funcionamento apropriado do modelo apresentam-se no trabalho, portanto estes deverão ser adotados com base em outras lagoas.

A validação não é um carimbo de aprovação do modelo, mas uma indicação do nível de confiança em seu comportamento diante de condições limitadas e para determinado propósito, basicamente a resposta à pergunta: “Esse modelo é útil?". Um fator importante para a validação de um modelo são os dados que são inseridos no mesmo, ou seja, se eles fornecem uma ligação tangível entre o modelo e seu sistema de referência. Um modelo que reproduz com aproximação os dados observados em comportamentos passados ganha credibilidade, aceitação e confiança de seus usuários em potencial (FORD, 1999; GREENBERGER, CRENSON, CRISSEY, 1976 apud FORD, 1999). 
O grande problema que envolve a utilização e adoção dos valores dos dados é o princípio do GIGO (Garbage In, Garbage Out) ou, em português, LELIS (Se lixo entra, então lixo sai). 0 mesmo demonstra que caso sejam usados valores discrepantes, incorretos (outliers), até mesmo o melhor dos modelos gerará resultados incorretos (CHWIF e MEDINA, 2006).

Os dados apresentados na Tabela 6 foram obtidos na ETE - Estação de Tratamento de Esgoto - de Balneário Camboriú, locada no Município de Balneário Camboriú, Santa Catarina, latitude $27^{\circ} 01^{\prime} 06.9^{\prime \prime} \mathrm{S}$ e longitude $48^{\circ} 37^{\prime} 19.0^{\prime \prime} \mathrm{W}$, altitude de $6 \mathrm{~m}$. A lagoa facultativa estudada totalizava uma área de $63.200 \mathrm{~m}^{2} \mathrm{e}$ profundidade de $1,75 \mathrm{~m}$. Quando coletadas as amostras a companhia responsável pela sua operação era a CASAN - Companhia Catarinense de Águas e Saneamento. A ETE consistia de um sistema australiano com dois módulos, duas lagoas anaeróbias seguidas de duas lagoas facultativas (PEDRELLI, 1997).

Durante o estudo realizou-se o controle analítico em nove pontos pré-determinados, esse estudo durou um ciclo, de fevereiro/1996 à março/1997. A frequência da amostragem era:

- Diária: Temperatura do Ar, Temperatura do Esgoto, pH, Alcalinidade, Cloretos, Sólidos Sedimentáveis e Oxigênio Dissolvido (O.D.);

- Semanal: $\mathrm{DBO}_{5}, \mathrm{DBO}_{5}$ solúvel, DQO, DQO solúvel;

- Quinzenal: Sólido Totais, Sólidos Totais Fixos, Sólidos Totais Voláteis e Sólidos Suspensos;

- Mensal: Coliforme Total e Fecal, Nitrogênio Total e Amoniacal, Fosfato Total, Nitrito, Nitrato e perfil diário do O.D (coletas eventuais).

O trabalho não apresentava a concentração de algas e bactérias (Xai e Xbi), do carbono inorgânico total (Cti) e do fósforo orgânico e inorgânico (Pii e Poi), portanto elas foram adotadas de outro referencial bibliográfico.

Tabela 6 - Resultados Operacionais da Lagoa Facultativa de Balneário Camboriú/SC.

\begin{tabular}{|c|c|c|c|}
\hline Parâmetro & Valor & Unidade & Fonte \\
\hline Temperatura Média & 20,6 & ${ }^{\circ} \mathrm{C}$ & PEDRELLI, 1997 \\
\hline Amplitude Térmica & 16,3 & ${ }^{\circ} \mathrm{C}$ & PEDRELLI, 1997 \\
\hline TDH & 17 & dias & PEDRELLI, 1997 \\
\hline $\mathrm{Si}$ & 210 & $\mathrm{mg} / \mathrm{l}$ & PEDRELLI, 1997 \\
\hline Xbi & 1 & $\mathrm{mg} / \mathrm{l}$ & FRITZ, 1985 \\
\hline Xai & 1 & $\mathrm{mg} / \mathrm{l}$ & FRITZ, 1985 \\
\hline $\mathrm{O}_{2} \mathrm{i}$ & 0 & $\mathrm{mg} / \mathrm{l}$ & PEDRELLI, 1997 \\
\hline Noi & 8,48 & $\mathrm{mg} / \mathrm{l}$ & PEDRELLI, 1997 \\
\hline $\mathrm{NH}_{4} \mathrm{i}$ & 35,35 & $\mathrm{mg} / \mathrm{l}$ & PEDRELLI, 1997 \\
\hline $\mathrm{NO}_{3} \mathrm{i}$ & 0,45 & $\mathrm{mg} / \mathrm{l}$ & PEDRELLI, 1997 \\
\hline Poi & 3,05 & $\mathrm{mg} / \mathrm{l}$ & TRUPPEL, 2002 \\
\hline Pii & 6,09 & $\mathrm{mg} / \mathrm{l}$ & TRUPPEL, 2002 \\
\hline Cti & 60 & $\mathrm{mg} / \mathrm{l}$ & FRITZ, 1985 \\
\hline ALKi & 238 & $\mathrm{mg} / \mathrm{l}$ & PEDRELLI, 1997 \\
\hline
\end{tabular}

Foram realizadas três simulações (Tabela 7), na primeira usaram-se os valores chamados de típicos, na segunda os valores mínimos e na terceira valores máximos. Foram modificados somente aqueles coeficientes bioquímicos que possuíam um intervalo de variação informados nas mesmas fontes da Tabela 5 (Y, K20, Ks, Kb20, $\beta$ e $\mu \mathrm{N}$ ), para os outros adotou-se os valores apresentados como típicos nessa mesma Tabela. 
Tabela 7 - Valores dos coeficientes bioquímicos utilizados nas Simulações.

\begin{tabular}{|c|c|c|c|c|}
\hline \multirow[b]{2}{*}{ Coeficiente } & \multicolumn{3}{|c|}{ Valores Testados } & \multirow[b]{2}{*}{ Unidade } \\
\hline & $\begin{array}{c}\text { Simulação 1: } \\
\text { Coeficiente Típico }\end{array}$ & $\begin{array}{c}\text { Simulação 2: Coeficiente } \\
\text { Mínimo }\end{array}$ & $\begin{array}{c}\text { Simulação 3: } \\
\text { Coeficiente } \\
\text { Máximo }\end{array}$ & \\
\hline $\mathrm{Y}$ & 0,4 & 0,3 & 0,8 & $\mathrm{mg}$ VSS/mg bsDQO \\
\hline $\mathrm{K} 20$ & 5 & 2 & 10 & dia $^{-1}$ \\
\hline Ks & 40 & 10 & 60 & $\mathrm{mg} / \mathrm{l} \mathrm{bsDQO}$ \\
\hline $\mathrm{Kb} 20$ & 0,35 & 0,25 & 0,4 & dia-1 \\
\hline $\mathrm{KO}_{2}$ & 1,1 & 0,08 & 1,1 & $\mathrm{mg} / \mathrm{l}$ \\
\hline$\beta$ & 1,07 & 1,05 & 1,085 & - \\
\hline$\mu \mathrm{N}$ & 0,008 & 0,002 & 0,008 & dia $^{-1}$ \\
\hline
\end{tabular}

\section{RESULTADOS}

\subsection{VERIFICAÇÃO DO MODELO}

Para a verificação do modelo fez-se uma análise comparativa entre o gráfico obtido na simulação e os resultados apresentados pelas amostras compostas coletadas por Silva (1982). Essa comparação foi realizada com DQO(S), $\mathrm{NH}_{4}, \mathrm{Pt}$ - Fósforo Total, OD - Oxigênio Dissolvido $\left(\mathrm{O}_{2}\right)$, pH e Temperatura.

Como em suas coletas Silva (1982) apontou o valor máximo, mínimo e médio das amostras, três novas curvas foram inseridas dentro das simulações, sendo elas ValorMáximo, ValorMínimo e ValorMédio, respectivamente. Com isso busca-se facilitar a comparação e análise dos resultados.

\subsection{DEMANDA QUÍMICA DE OXIGÊNIO - DQO(S)}

A DQO solúvel é apresentada no modelo como S e é calculada com base na Equação (1). As curvas geradas no modelo a partir das amostras de Silva (1982) apresentam-se na Figura 1.

Figura 1 - Curvas da DQO (S) obtidas do Modelo Computacional de Fritz (1985) e das amostras de Silva (1982).

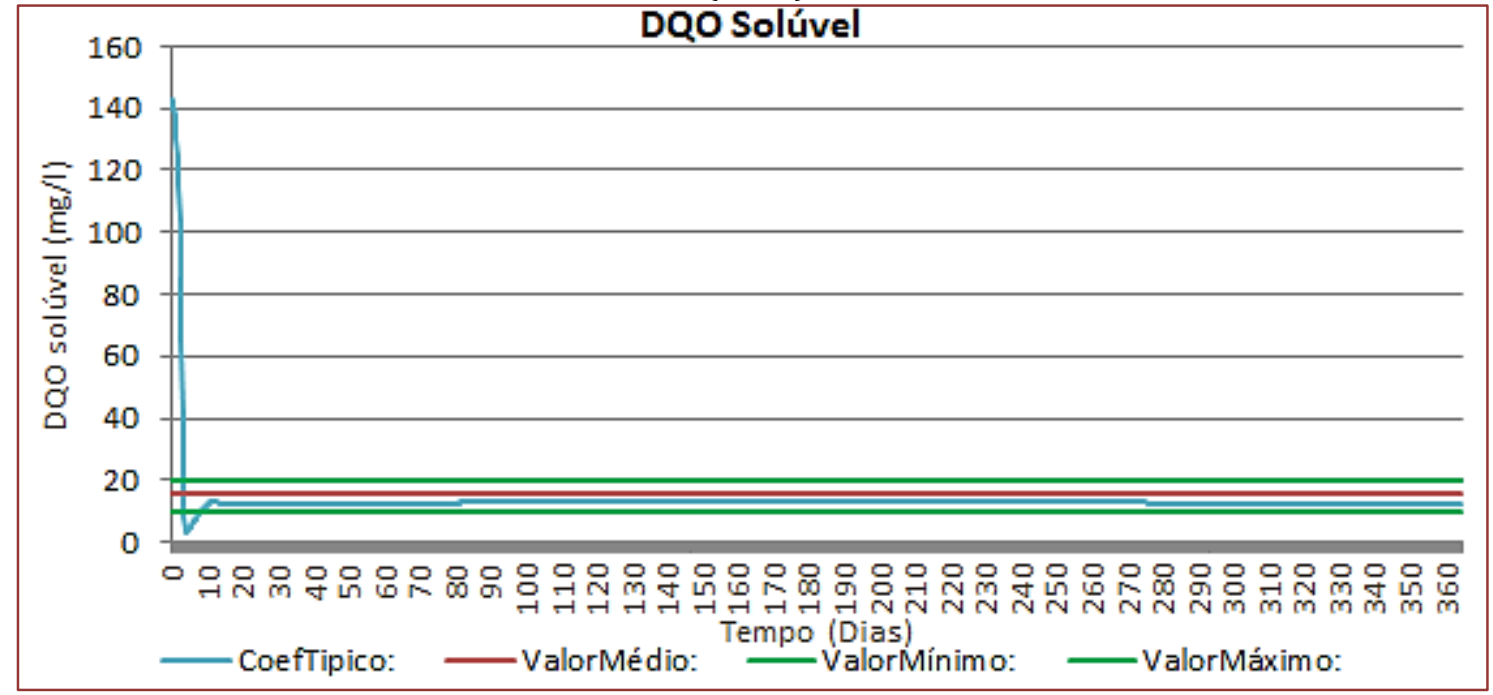

Na Figura 1 é possível observar que a curva da concentração de DQO Solúvel criada a partir da simulação do Modelo Computacional encontra-se entre as curvas de ValorMédio e ValorMínimo na maior parte dos 365 dias. A grande variação encontrada entre o dia 0 (zero) e 15, aproximadamente, pode ser explicada pelo comportamento do modelo computacional em si, ou seja, ele necessita desse tempo para encontrar o seu equilíbrio. 


\subsection{CONCENTRAÇÃO DE N-AMONIACAL - NH4}

O N-Amoniacal é apresentado no modelo como $\mathrm{NH}_{4}$ e é calculado com base na Equação (6). As curvas geradas no modelo a partir das amostras de Silva (1982) apresentam-se na Figura 2.

Figura 2 - Curvas do N-Amoniacal $\left(\mathrm{NH}_{4}\right)$ obtidas do Modelo Computacional de Fritz (1985) e das amostras de Silva (1982).

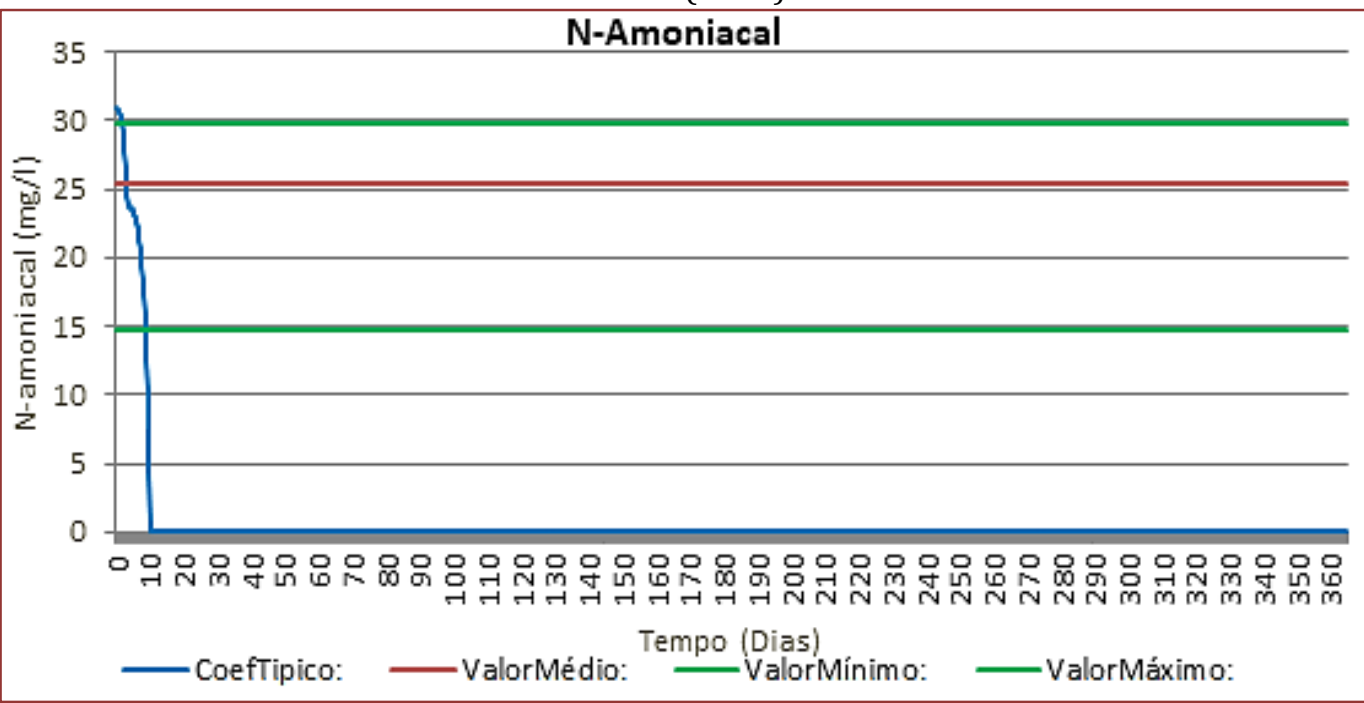

Diferentemente do resultado apresentado pelo DQO solúvel, quando se analisa a concentração de $\mathrm{N}$ Amoniacal do modelo, pode-se dizer que o valor obtido pela simulação durante a maior parte dos 365 dias encontra-se em 0 (Zero), portanto não condiz com os resultados amostrados. Destaca-se ainda que o único período em que a concentração ficou dentro do obtido pelas coletas foi durante o período inicial de 15 dias, ou seja, enquanto o modelo buscou o seu equilíbrio, portanto pode-se admitir que em nenhum momento o modelo atendeu a realidade.

\subsection{CONCENTRAÇÃO DE FÓSFORO TOTAL - Pt}

Calculado por meio da soma dos resultados do Fósforo Inorgânico (Equação 8) e Orgânico (Equação 9), as curvas para a Concentração de Fósforo Total são apresentadas na Figura 3.

Figura 3 - Curvas do Fósforo Total (Pt) obtidas do Modelo Computacional de Fritz (1985) e das amostras de Silva (1982).

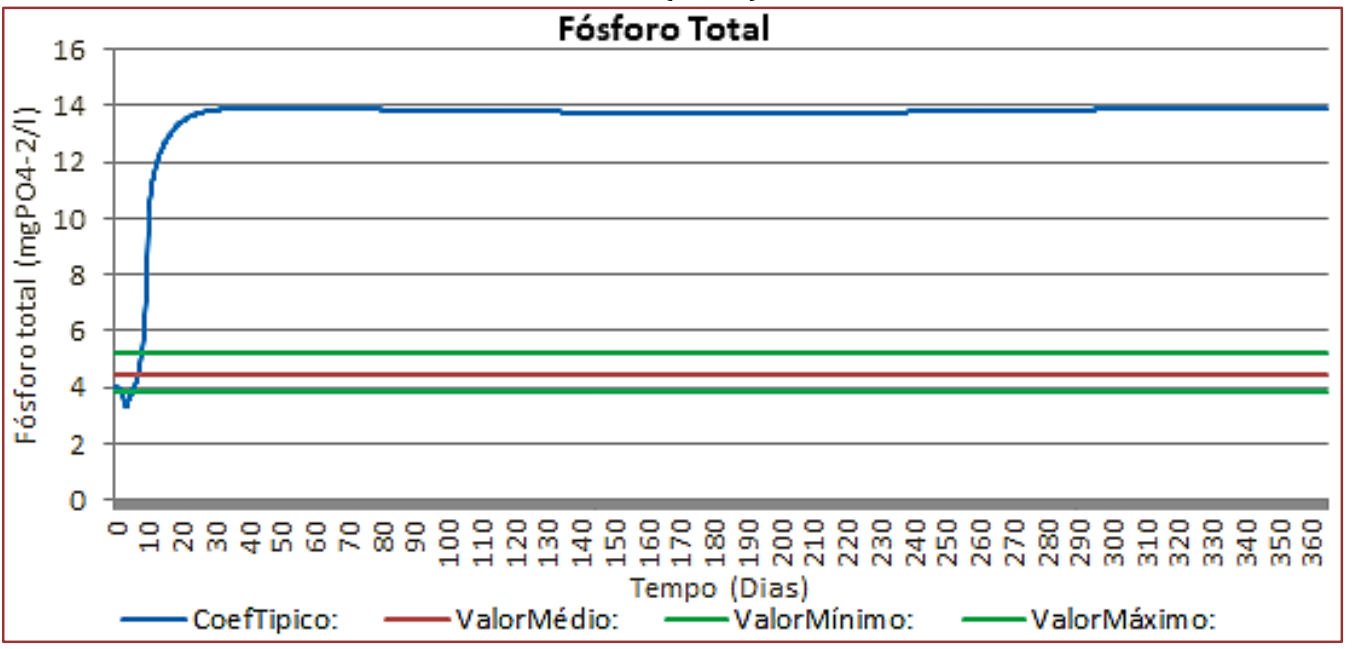


Com base na Figura 3, pode-se afirmar que para a concentração de Fósforo Total (Pt) ocorreu o inverso do observado para a concentração de N-Amoniacal, ou seja, a curva da simulação (CoefTípico) encontra-se acima do amostrado por Silva (1982), enquanto o valor máximo da amostra era de 5,22 $\mathrm{mgPO}_{4}^{-2} / \mathrm{l}$ a simulação variou seu valor entre 13 e $14 \mathrm{mgPO}_{4}^{-2} / \mathrm{l}$ durante a maior parte dos 365 dias. Assim como para os outros parâmetros, do dia 0 (zero) ao dia 15, houve o período para o modelo computacional encontrar o seu equilíbrio, podendo ser descartados.

\subsection{CONCENTRAÇÃO DE OXIGÊNIO DISSOLVIDO - $\mathrm{O}_{2}$}

Calculado por meio da Equação (4). A curva gerada para a concentração de oxigênio dissolvido $\left(\mathrm{O}_{2}\right)$ no modelo apresentam-se na Figura 4.

Figura 4 - Curvas do Oxigênio Dissolvido $\left(\mathrm{O}_{2}\right)$ obtidas do Modelo Computacional de Fritz (1985) e das amostras de Silva (1982).

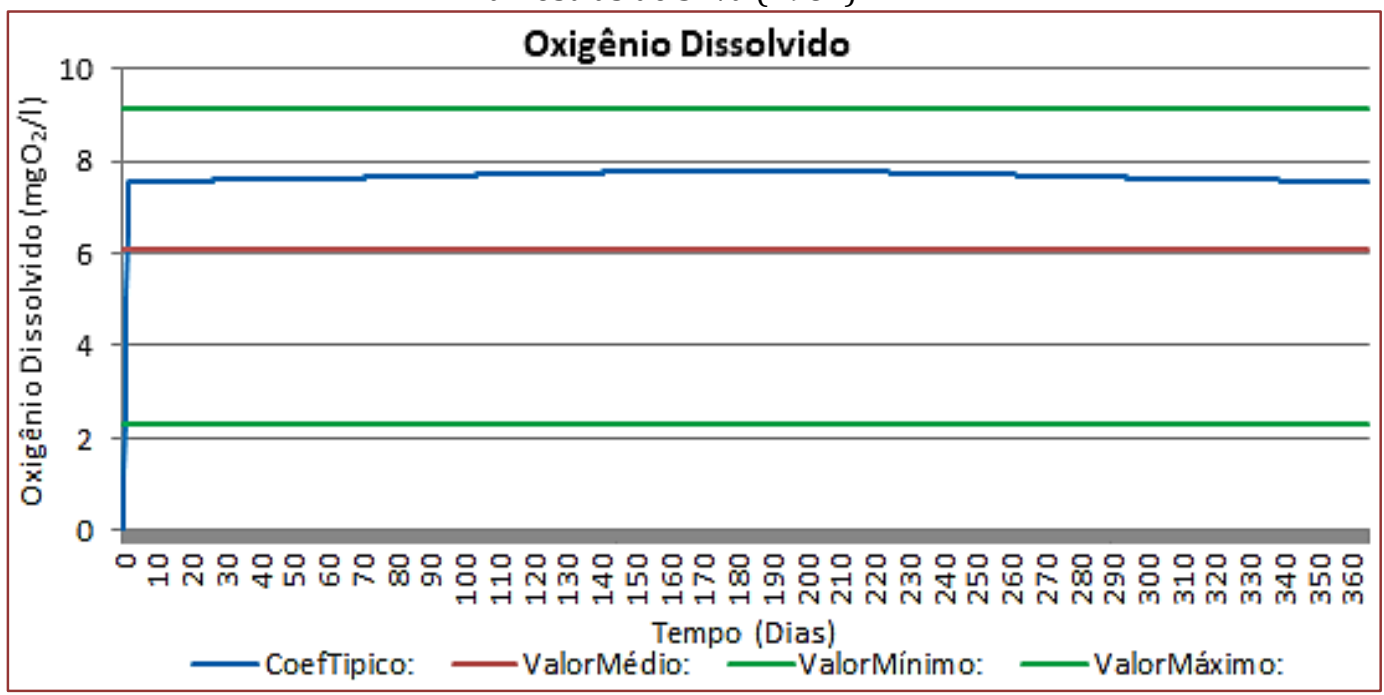

A simulação para a concentração de Oxigênio Dissolvido, assim como para a DQO, apresentou um resultado condizente com as amostras de Silva (1982). A curva CoefTípico encontra-se na maior parte do intervalo de 365 dias entre as curvas ValorMédio e ValorMáximo.

\subsection{POTENCIAL HIDROGENIÔNICO - pH}

Para as curvas de pH tem-se a Figura 5:

Figura 5 - Curvas do Potencial Hidrogeniônico (pH) obtidas do Modelo Computacional de Fritz (1985) e das amostras de Silva (1982).

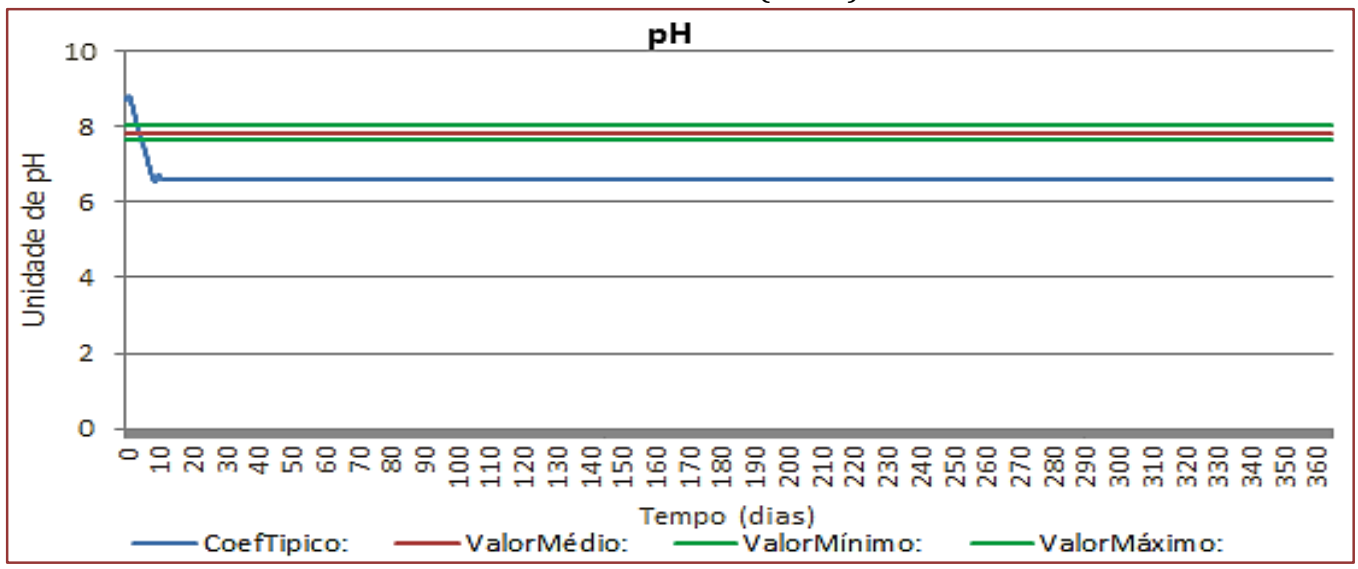


Para as curvas de pH ocorreu algo semelhante ao observado no N-Amoniacal. Ou seja, a Figura 5 demonstra que a curva CoefTípico encontra-se abaixo dos valores máximos amostrados por Silva (1982). Entretanto, nesse caso o valor médio de Silva (1982) é de 7,8 unidades de pH, enquanto a simulação apresentou uma curva variável entre 6,5 e 6,7, ou seja, um valor, aproximadamente, 15\% menor que o real.

\subsection{TEMPERATURA}

As curvas da Temperatura são apresentadas na Figura 6:

Figura 6 - Curvas da Temperatura obtidas do Modelo Computacional de Fritz (1985) e das amostras de Silva (1982).

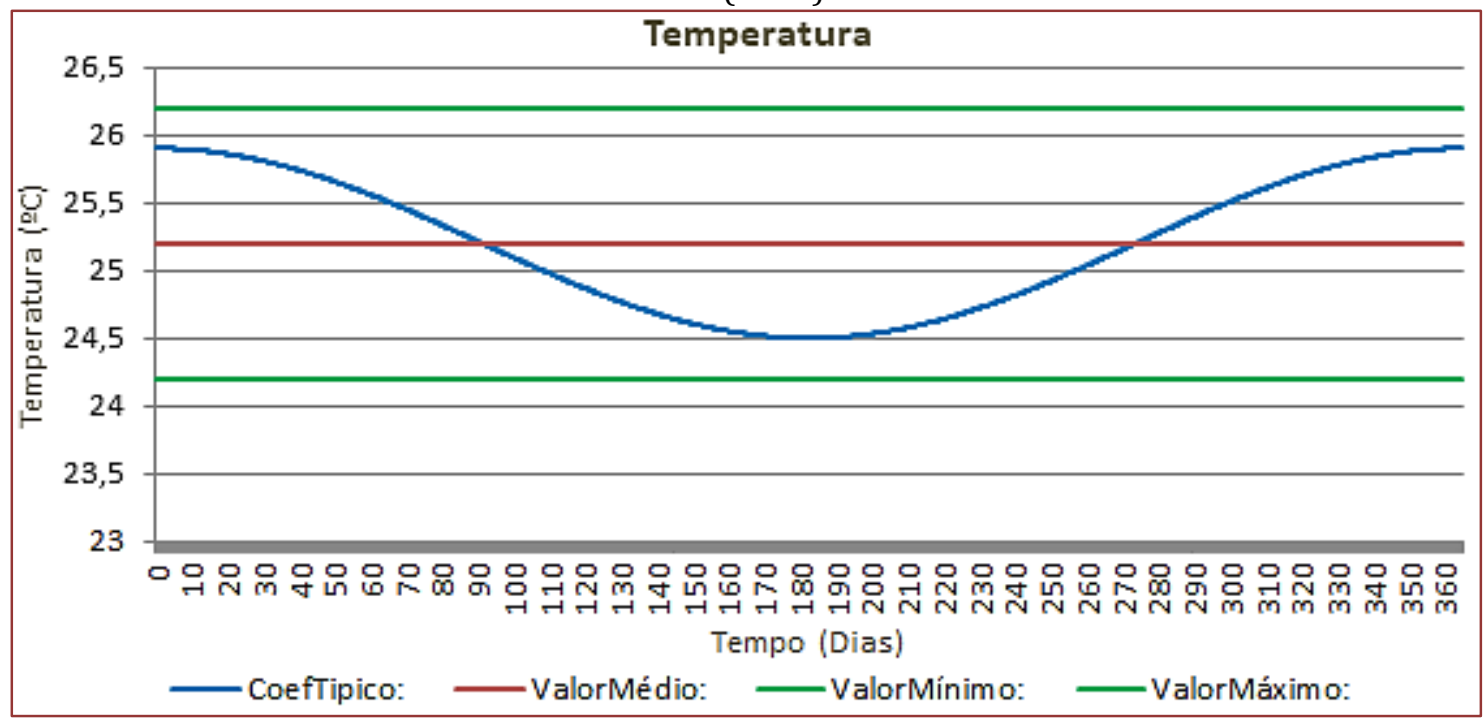

Conforme a Figura 6 destaca-se que, por se tratar de uma lagoa na região nordeste do Brasil não existe uma grande amplitude térmica e, além disso, uma característica do clima tropical brasileiro, no inverno (dia 171 até 265) encontram-se as menores temperaturas e no verão (dia 0 até 78 e dia 351 até 365 ) as maiores. No caso da curva do CoefTípico, entre todas as curvas analisadas para as amostras de Silva (1982), essa foi a que apresentou maior variação de valores. Entretanto em nenhum momento ultrapassou os limites das amostras durante os 365 dias.

\subsection{VALIDAÇÃO DO MODELO}

Para os resultados da validação fez-se uma análise comparativa entre os gráficos obtidos como resposta final do modelo e os dados obtidos através de amostras coletadas na lagoa facultativa estudada por Pedrelli (1997). Esse estudo comparativo relativo foi feito com as amostras de DQO, DQO solúvel, NTK, $\mathrm{NH}_{4}, \mathrm{pH}, \mathrm{OD}$ - Oxigênio Dissolvido $\left(\mathrm{O}_{2}\right)$, Alcalinidade.

A terceira simulação com os valores máximos apresentou erros na renderização e os gráficos mostrados pelo VenSim PLE® estavam bem diferentes das curvas obtidas na simulação 1 e 2. Portanto, a curva da terceira simulação foi descartada dos gráficos comparativos finais.

Tendo em vista que o modelo considera uma concentração de afluente constante e na realidade a concentração varia conforme o tempo, determinou-se que a partir das curvas obtidas nas simulações 1 e 2 deveriam ser criadas outras duas curvas, uma aumentando em 10\% (1.1CoefTipico) e outra reduzindo em 10\% (0.9CoefTipico) a curva CoefTipico, assumindo que 10\% é um erro considerado aceitável e a fim de que a análise seja mais condizente com uma lagoa real. 


\subsection{DEMANDA QUÍMICA DE OXIGÊNIO - DQO (S)}

As curvas geradas no modelo para a DQO(S) apresentam-se no Figura 7.

Figura 7 - Curvas da DQO (S) obtida no Modelo Computacional de Fritz (1985).

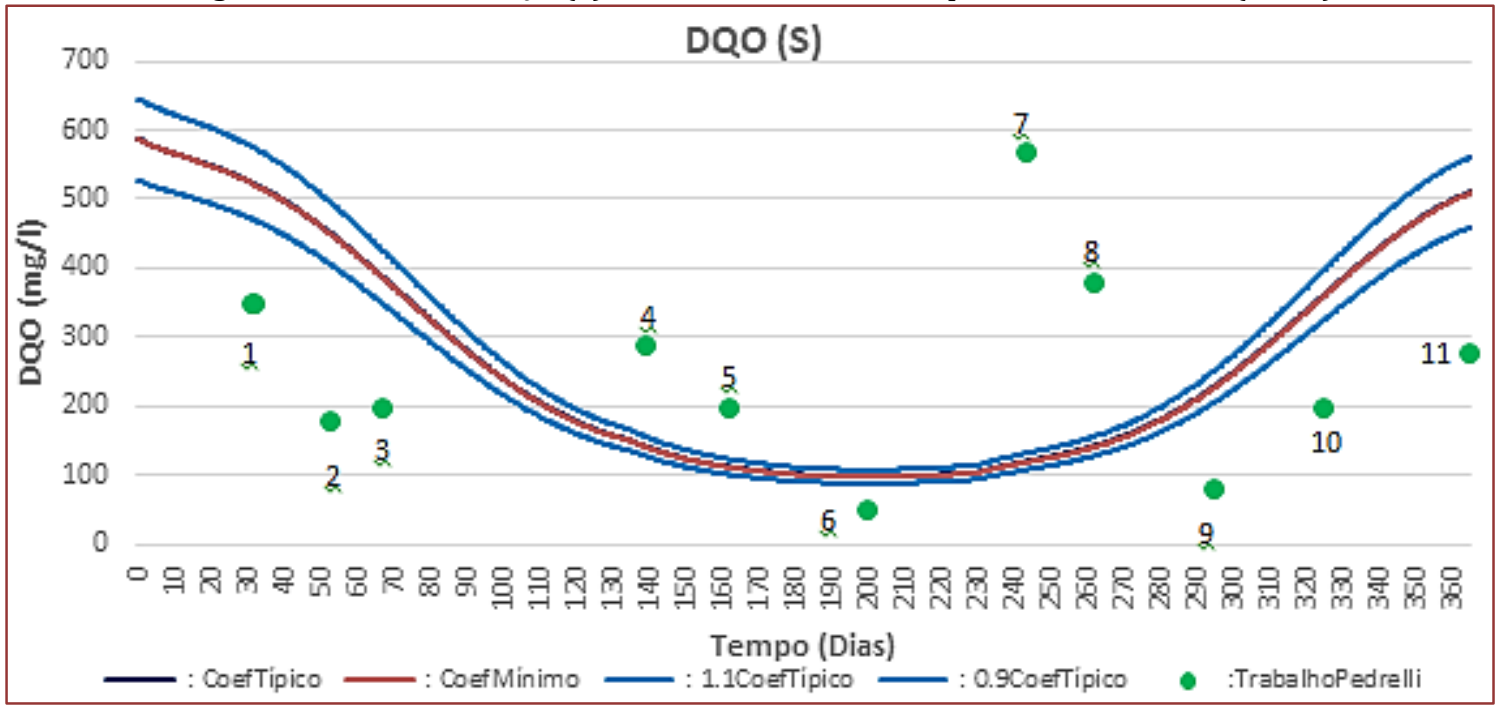

Na Figura 7 pode-se observar que as curvas do Coeficiente Típico e do Coeficiente Mínimo não apresentam diferença visual, além disso dos onze pontos obtidos do trabalho de Pedrelli (1997), nenhum se encontra dentro do intervalo estipulado entre a curva 0.9CoefTípico e 1.1CoefTípico. Dos onze pontos obtidos, quatro encontram-se acima do conjunto de curvas e sete abaixo. Indicando que em 63,3\% das amostras colhidas, a concentração real de DQO do efluente é menor do que a obtida para o mesmo dia no modelo.

\subsection{DEMANDA QUÍMICA DE OXIGÊNIO SOLÚVEL - DQO SOLÚVEL (St)}

A DQO Solúvel é apresentada no modelo como St. Na Figura 8 são apresentadas as curvas geradas.

Figura 8 - Curvas da DQO Solúvel (St) obtida no Modelo Computacional de Fritz (1985).

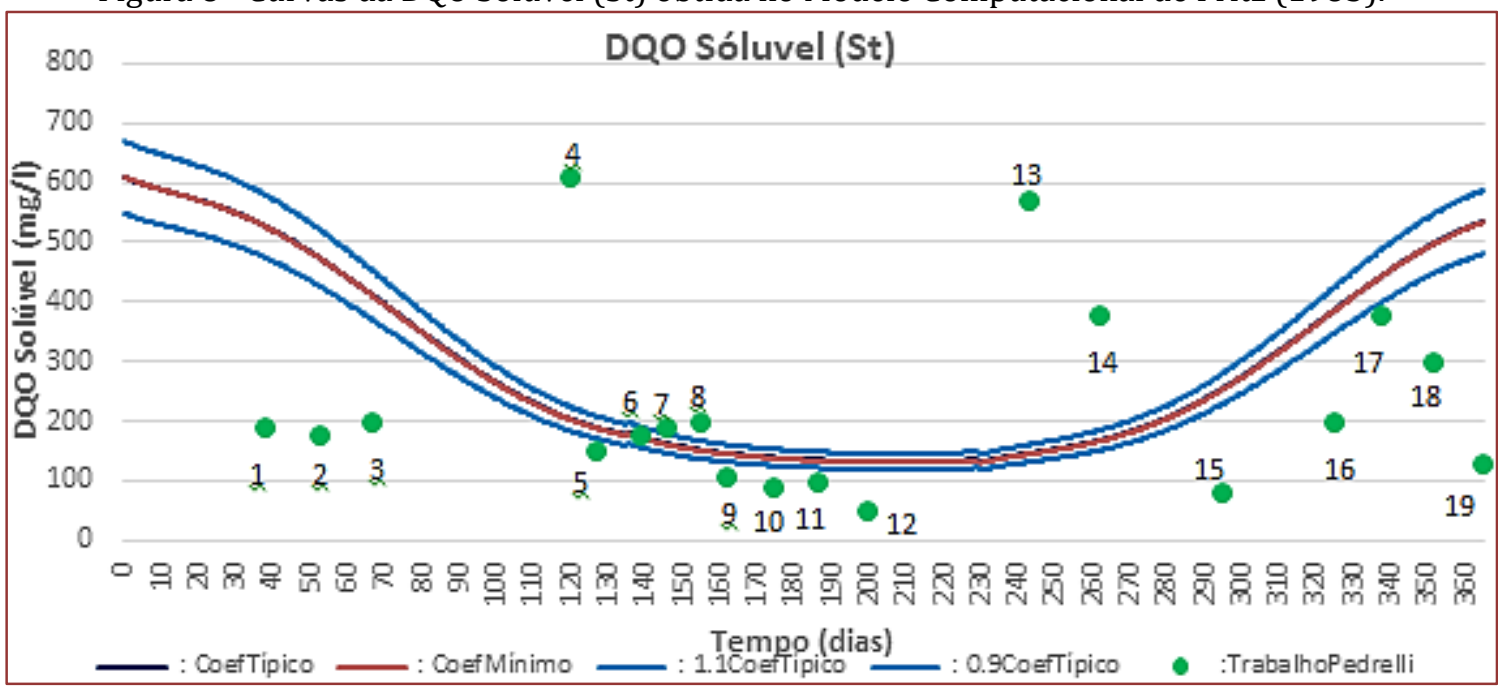

Observando a Figura 8, chega-se a mesma conclusão obtida na Figura 7: as curvas Coeficiente Típico e Coeficiente Mínimo não apresentam diferença visual. Dos 19 pontos obtidos da lagoa real, 1 (um) encontra-se dentro do intervalo das curvas (Ponto 6), 3 (três) pelo menos o tocam (Pontos 7,11 e 17) e 2 
(dois) estão muito próximos (Pontos 5 e 9). Portanto, 21,1\% dos pontos analisados possuem algum tipo de contato com o conjunto e 10,5\% apresentam-se bem próximos dos resultados obtidos pelo modelo.

Dos 13 pontos restantes, 9 encontram-se abaixo do conjunto e 4 acima, ou seja, em 47,4\% das amostras colhidas a concentração real de DQO solúvel do efluente é menor do que a obtida para o mesmo dia no modelo.

\subsection{CONCENTRAÇÃO DE NITROGÊNIO TOTAL KIELDHAL - NTK}

O NTK foi calculado através da soma do $\mathrm{NH}_{4}$ com o No. Os resultados são apresentados na Figura 9.

Figura 9 - Curvas do NTK obtida no Modelo Computacional de Fritz (1985).

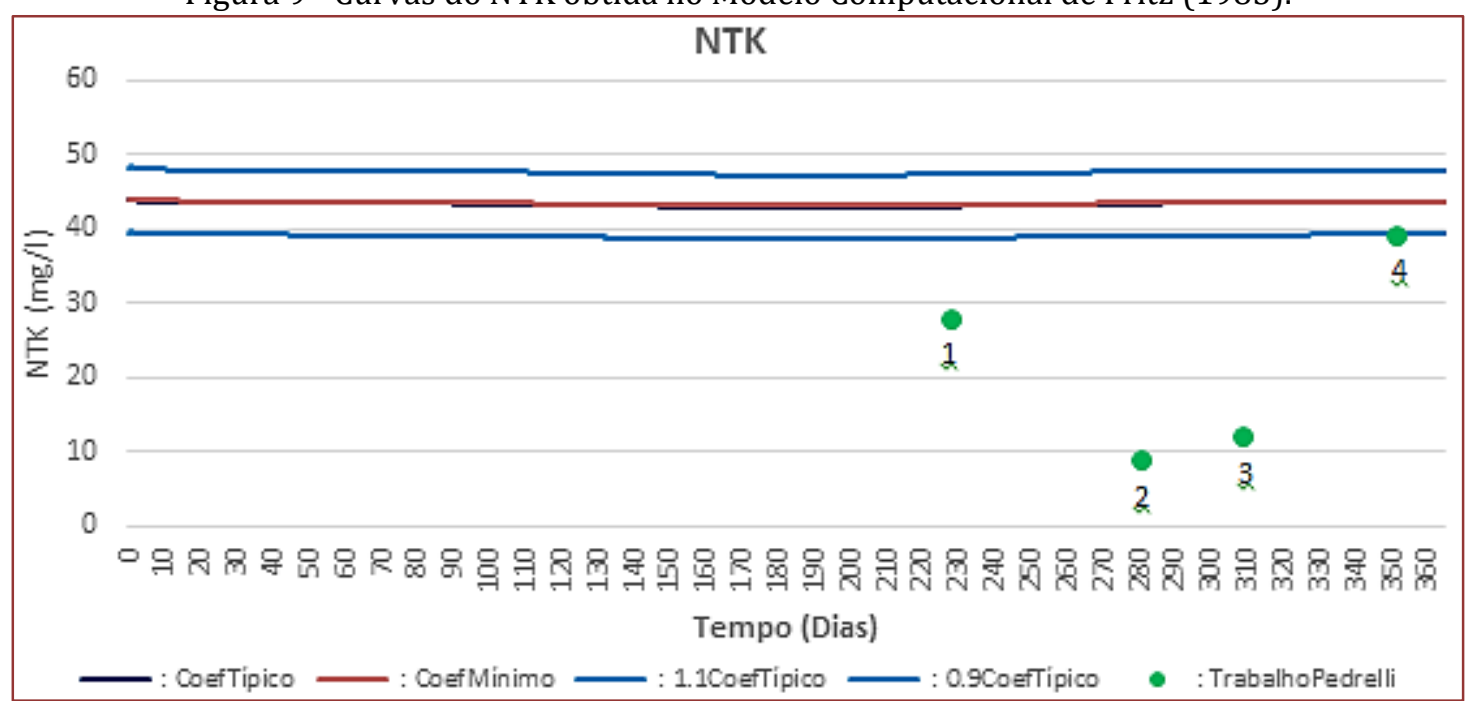

De acordo com a Figura 9, dos 4 (quatro) pontos que representam as amostras da lagoa facultativa, um está dentro do intervalo das curvas (Ponto 4) e os outros três estão abaixo. Então, 25\% das amostras apresentam-se dentro do que foi gerado pelo modelo e os outros $75 \%$ encontram-se com valores inferiores, ou seja, com a concentração real de NH4 no efluente menor do que a simulada.

\subsection{CONCENTRAÇÃO DE NITROGÊNIO AMONIACAL - NH4}

As curvas geradas no modelo para o Nitrogênio Amoniacal apresentam-se na Figura 10.

Figura 10 - Curvas de NH4 obtida no Modelo Computacional de Fritz (1985).

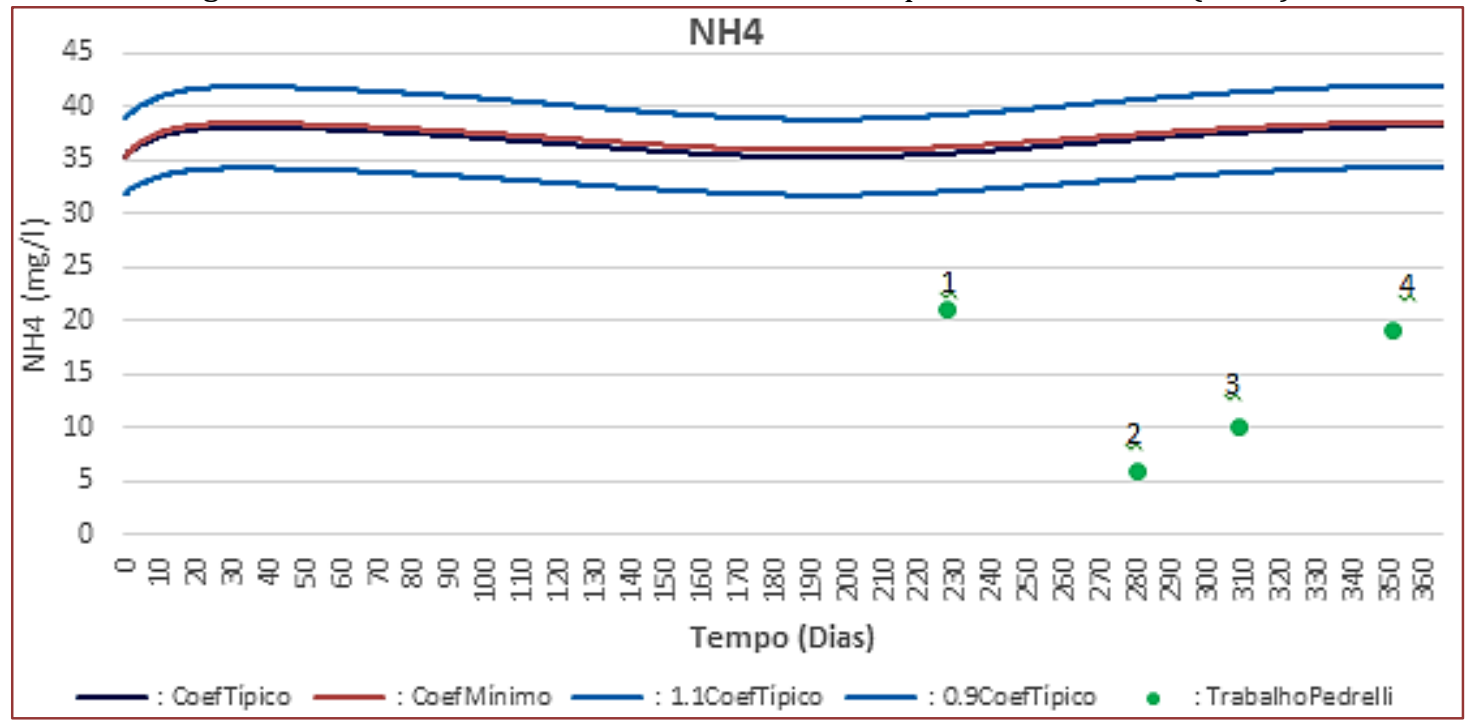


Conforme a Figura 10 pode-se afirmar que as curvas Coeficiente Típico e Coeficiente Mínimo não apresentam diferença visual. Dos quatro pontos obtidos do trabalho de Pedrelli (1997), nenhum entra em contato com o conjunto de curvas e todos encontram-se abaixo dele. Logo, a concentração real de $\mathrm{NH}_{4}$ do efluente é menor do que a obtida pelo modelo.

\subsection{POTENCIAL HIDROGENIÔNICO - pH}

As curvas obtidas durante as simulações para o potencial hidrogeniônico $(\mathrm{pH})$ são apresentadas na Figura 11.

Figura 11 - Curvas de pH obtida no Modelo Computacional de Fritz (1985).

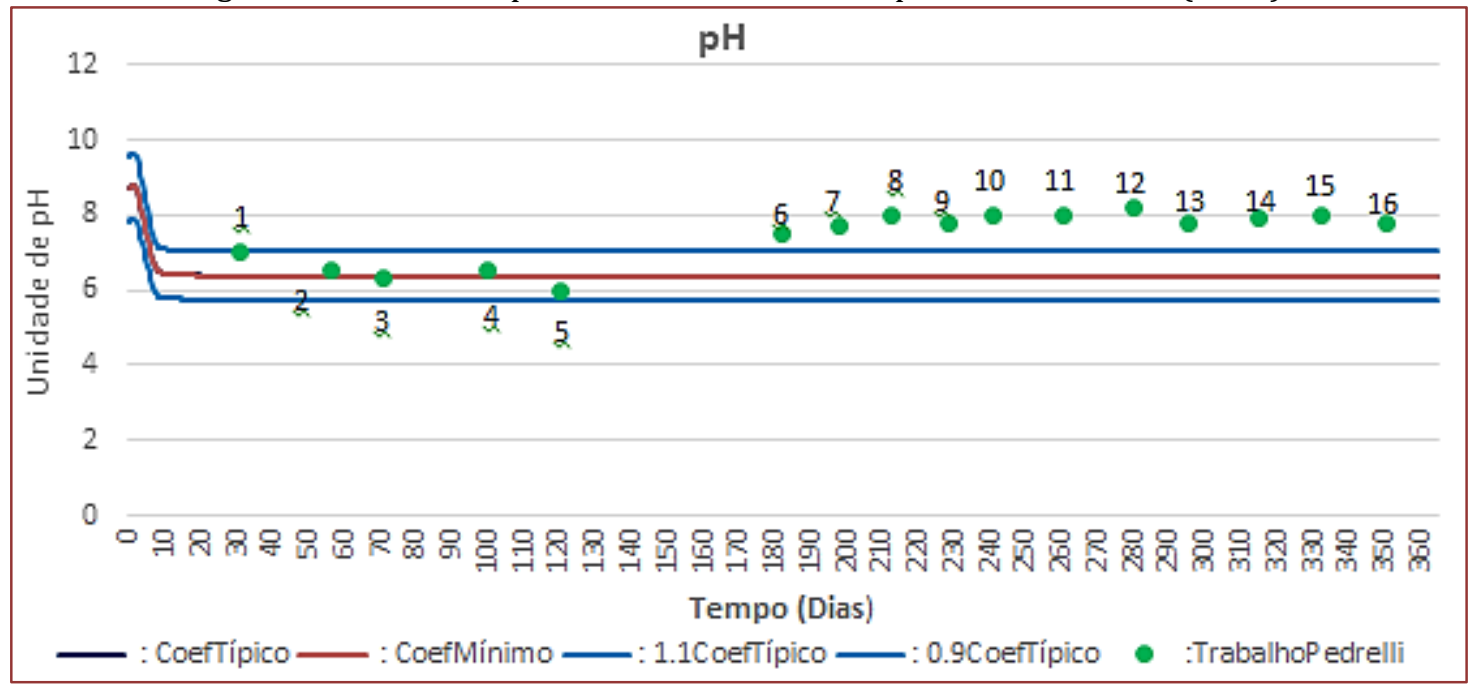

Conforme a Figura 11 novamente ambas as curvas, Coeficiente Mínimo e Típico, apresentam-se visualmente idênticas. Em relação aos 16 pontos obtidos no trabalho de Pedrelli (1997), observa-se que no intervalo de pontos que vai de 1 à 5 , todos encontram-se dentro do conjunto de curvas, ou seja, encontram-se entre as curvas 0.9CoefTípico e 1.1CoefTípico. Além disso, do ponto 6 à 16, todos localizamse acima desse conjunto. Portanto, 37,5\% dos pontos estavam dentro de um resultado satisfatório em relação ao modelo, enquanto os 62,5\% restantes apresentaram resultados superiores aos obtidos nas simulações.

\subsection{OXIGÊNIO DISSOLVIDO (OD) - $\mathrm{O}_{2}$}

Os resultados obtidos no modelo para o Oxigênio Dissolvido são demonstrados na Figura 12.

Figura 12 - Curvas de OD obtidas no Modelo Computacional de Fritz (1985).

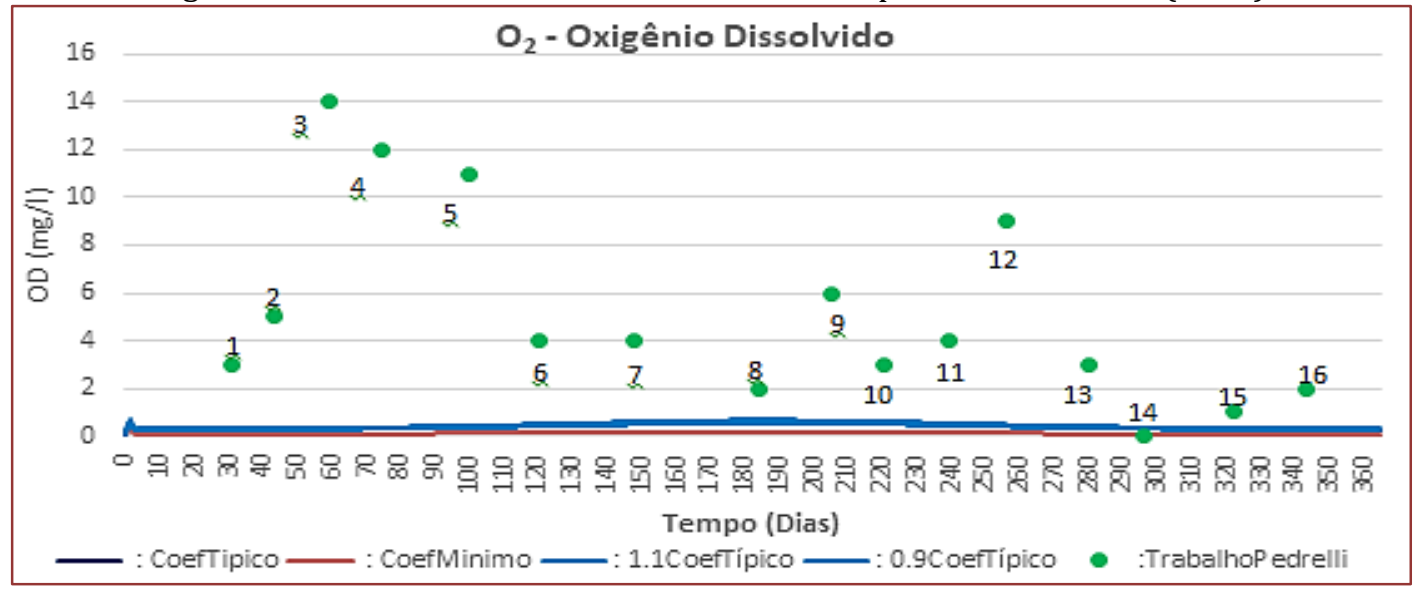


Através da análise da Figura 12 é possível afirmar que, diferentemente do que ocorreu com as outras simulações, existe uma diferença visual entre as curvas de Coeficiente Típico e Mínimo, onde a primeira citada apresenta uma maior concentração de oxigênio dissolvido do que a segunda. Dos 16 pontos obtido do trabalho de Pedrelli (1997), somente um encontra-se dentro do intervalo de curvas, o ponto 14 . Os outros 15 pontos demonstram que o modelo apresenta um resultado de simulação na qual a concentração é inferior ao que é obtido na lagoa. Portanto 93,75\% dos pontos analisados apresentavam a concentração de oxigênio na lagoa facultativa superior ao indicado pelo modelo nesse mesmo dia e diante das mesmas condições.

\subsection{ALCALINIDADE - ALK}

O cálculo da alcalinidade é feito por meio da Equação (11), as curvas obtidas pela simulação são representadas na Figura 13.

Figura 13 - Curvas de alcalinidade obtidas no Modelo Computacional de Fritz (1985).

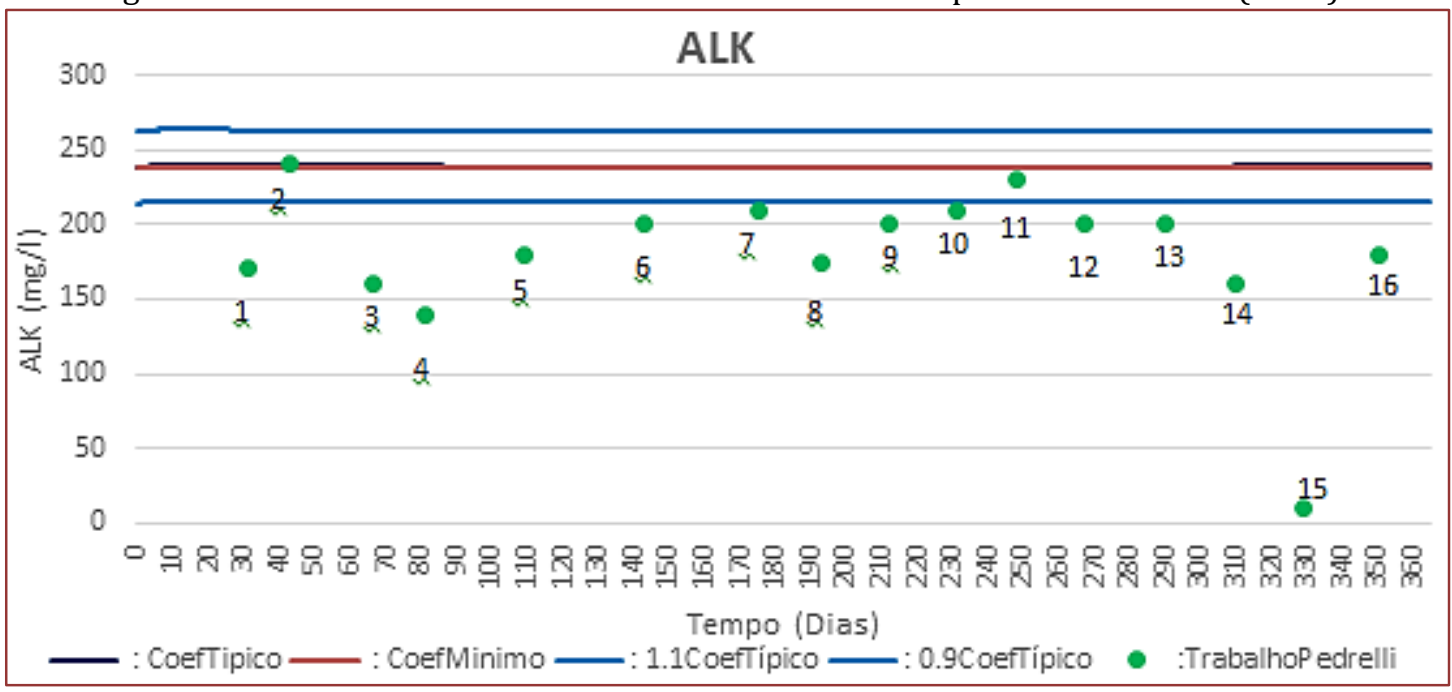

De acordo com a Figura 14, novamente as curvas representativas do Coeficiente Típico e Mínimo apresentam-se visualmente idênticas. Dos 16 pontos analisados, dois (pontos 2 e 11) encontram-se dentro do intervalo correspondido pelas as curvas 0.9CoefTípico e 1.1CoefTípico, outros dois (pontos 7 e 10) pelo menos encostam na curva 0.9CoefTípico e quatro (pontos 6, 9, 12 e 13) encontram-se relativamente próximos (diferença de aproximadamente $10 \mathrm{mg} / \mathrm{l}$ ). Os outros 8 pontos apresentam-se abaixo do conjunto, indicando que os resultados obtidos pela simulação são de valores superiores aos mostrados em campo.

Portanto, para essa simulação 50\% dos pontos apresentavam valores satisfatórios, enquanto os outros $50 \%$ estavam com uma concentração abaixo do valor obtido para o mesmo dia no modelo computacional de Fritz (1985).

\section{DISCUSSÃO}

\subsection{VERIFICAÇÃO DO MODELO}

A análise dos gráficos gerados na verificação do Modelo Computacional de Fritz (1985) apresentaram resultados para alguns parâmetros que estão dentro e para outros que se diferem do que é encontrado em lagoas reais. Dentre esses parâmetros aqueles que estão de acordo com as amostras da lagoa facultativa de Silva (1982) são DQO solúvel, Oxigênio Dissolvido e Temperatura. Já os que tiveram simulações bem diferentes do observado em campo foram N-Amoniacal e Fósforo Total. Em relação ao pH, a simulação estava fora do intervalo das coletas, entretanto com uma porcentagem diferencial menor do que os outros parâmetros (15\%).

Quando diz-se respeito ao Fósforo Total, a grande diferença foi dada pelo valor final do fósforo inorgânico (aproximadamente $12 \mathrm{mg} / \mathrm{l}$ ), que somado com o fósforo orgânico chegou à variação de 13 à $14 \mathrm{mg} / \mathrm{l}$. 
Entretanto, quando verificado o modelo computacional não foram encontrados problemas ou erros em relação ao cálculo desse parâmetro.

Já o N-amoniacal, quando verificado o modelo computacional pode-se constatar que a Taxa de absorção de biomassa da amônia ( $\mathrm{r} 2 \mathrm{am}$ ) apresentou durante toda a simulação um valor próximo à -7,50 (menos sete e meio), tem-se que o fator de preferência ( $p 1$ ) favorece a amônia ( $p 1=1)$, portanto o resultado final desse parâmetro foi zero e não atendeu o que foi observado por Silva (1982).

Enquanto isso para o pH, apesar de apresentar um valor inferior ao medido por Silva (1982), ele se difere em $15 \%$, podendo ser um erro considerado aceitável. Outro fator que favorece esse parâmetro é que, apesar de discordante, ele se encontra dentro do que é estabelecido pela Resolução № 430, de 13 de Maio de 2011, do CONAMA, onde o pH do efluente de emissão pode variar entre 5 e 9.

Portanto, para o caso da lagoa de Silva (1982) existiram resultados representativos e o modelo pode ser corretamente verificado, além disso, levando em consideração as simulações, afirma-se que a lagoa operava como um reator de mistura completa, por estar localizada em uma região que tem como características um clima quente e com baixa amplitude térmica, com verões e invernos quentes, onde não existe a estratificação da coluna líquida apontada por Kellner e Pires (2002).

Outro fator importante para o sucesso da verificação é o tipo de amostra adotado por Silva (1982), ao realizar uma amostragem composta ele reduziu a variação de concentração dos parâmetros de entrada, tendo uma média diária. Porque em lagoas a variação dos valores da concentração do efluente é grande, por exemplo: uma amostra coletada às 7 horas da manhã quase não apresentará oxigênio dissolvido, enquanto se essa mesma coleta fosse às 14 horas, a concentração desse mesmo parâmetro seria alta.

\subsection{VALIDAÇ̃̃O DO MODELO}

Os gráficos gerados na validação do Modelo Computacional de Fritz (1985) apresentaram resultados que se diferem dos encontrados na lagoa real. Portanto podem ser tidos como não representativos. Dentre os parâmetros testados aqueles que mais se aproximaram das amostras da lagoa facultativa de Pedrelli (1997) foram a alcalinidade (ALK) e pH, isso pode ser justificado pelo fato de que para sofrerem variações as Equações do modelo necessitam que o coeficiente bioquímico r1a (Taxa de reação volumétrica da depleção da alcalinidade devido a nitrificação) tenha um valor alto, praticamente impossível de ser obtido devido às interdependências desse coeficiente, portanto ambos os parâmetros ficam praticamente constantes durante toda a simulação, isso aliado ao fato de que a alcalinidade e pH das lagoas facultativas pouco variam, tornaram ambos os parâmetros satisfatórios.

A DQO solúvel pode ser considerada como um resultado satisfatório, já que 31,6\% dos pontos tinham contato com o intervalo ou estavam bem próximos e da porcentagem restante, 47,4\% estavam abaixo do intervalo e $21 \%$ acima, portanto um número considerável de pontos foi similar ao simulado. Contudo quando comparado o resultado da DQO(S) da lagoa de Pedrelli (1997) com a de Silva (1982), o resultado da segunda lagoa foi menos significativo.

Em relação ao resultado apresentado pelo DQO, ele pode ser considerado insatisfatório. Observa-se um certo equilíbrio entre os pontos acima do intervalo de curvas $(36,7 \%)$ e os abaixo $(63,3 \%)$, mas não houve nenhum ponto atendido pelo modelo. Ou seja, em nenhum momento o modelo chegou perto do que era apresentado na lagoa.

Para os outros parâmetros: NTK, $\mathrm{NH}_{4}$ e $\mathrm{O}_{2}$, o fato de apresentarem nenhum ou poucos pontos atendidos durante a simulação pode ser explicado por uma série de condições que são adotadas pelo modelo e que podem se diferenciar da situação real da lagoa analisada.

A primeira condição adotada pelo modelo que se difere do que ocorre em lagoas é que a concentração dos afluentes é constante durante todo dia, semana e ano. Quando o que se encontra na realidade é uma variação diária, com picos nos períodos 6-12 e 18-20 horas, semanal e anual, aumento do consumo durante o verão (Dezembro-Março).

A segunda condição é uma consequência da primeira, o modelo considera que o balanço de massas é: entrada = saída, quando em muitas lagoas devido a variação da vazão dos afluentes somada ao fato da concentração de seus parâmetros também mudarem e a existência de zonas mortas faz com que essa condição não se satisfaça. Tais fatos também foram observados no modelo matemático de reator UASB desenvolvido por Carvalho (2006), a autora considerou, assim como no Modelo Fritz (1985), que existia a 
mistura completa, porém ao final do trabalho ela constatou a existência de zonas mortas que alteravam o TDH e consequentemente o balanço de massas.

A terceira condição é a mais significante: o modelo de Fritz adota a mistura completa. Ou seja, considera que não existe estratificação na lagoa ou, se existe, a lagoa possui a capacidade de se desestratificar durante a noite, causando a mistura completa. No entanto, conforme os trabalhos de Kellner e Pires (2002) e Kellner, Moreira e Pires (2009), nem todas as lagoas possuem essa capacidade e são estratificadas, dentre essas destacam-se lagoas de grandes dimensões ou que se localizam em áreas com temperaturas altas e pequena amplitude térmica durante o ano (por exemplo lagoas que estão na região Nordeste do país).

Além dessas condições, existe um outro fator que pode ser significante: as amostras coletadas por Pedrelli (1997) eram pontuais, sendo que, devido a hipótese da lagoa analisada ser estratificada e do fato das reações bioquímicas decorrentes dependerem muito da temperatura local, o método correto para a coleta seria composto, assim os pontos obtidos seriam referentes a uma média da concentração diária como os de Silva (1982).

Assim sendo, os padrões para validação do modelo não foram atendidos, grande parte por causa da lagoa que foi utilizada. Diferentemente da lagoa de Silva (1982), a de Pedrelli (1997) não operava em mistura completa e apresentava características de uma lagoa estratificada: grande amplitude térmica com verões quentes e invernos frios, podendo ser averiguado pela sua localização: Santa Catarina.

Além disso, para uma boa validação são necessários ótimos dados de entrada, o que não foi o caso. Partindo da premissa do "Se lixo entra, então lixo sai" (Garbage In Garbage Out), quando o modelo foi alimentado com informações de uma lagoa que não atendia sua principal condição: funcionar como mistura completa, e cuja coleta de amostras não foram feitas da melhor maneira (compostas), ele iria apresentar resultados insatisfatórios para alguns de seus parâmetros de simulações.

\section{CONCLUSÕES}

Com base no modelo matemático de Fritz (1985) foi possível desenvolver um modelo computacional na plataforma VenSim PLEß capaz de simular o comportamento de lagoas facultativas.

A verificação do modelo foi tida como bem sucedida, com base nos seus resultados pode-se dizer que a pergunta: “Será que o modelo foi desenvolvido corretamente?", pode ser respondida de modo afirmativo.

Os resultados foram satisfatórios graças à lagoa analisada, ela possuía a principal característica a qual o modelo era condicionado: mistura completa, porém quando Fritz escreveu seu artigo em 1985 ele não estabeleceu nenhum obstáculo para a aplicação de seu modelo para qualquer lagoa facultativa.

Evidencia-se que até meados de 1990, não acreditava-se que a estratificação da coluna líquida tivesse grande importância no comportamento do escoamento em lagoas de estabilização, principalmente por essas unidades possuírem pequena profundidade. Sendo apontada pelos pesquisadores Kellner e Pires em 2002.

Também foi importante o tipo de amostras de Silva (1982): compostas, o que reduz a variação da concentração dos parâmetros de entrada e produz um gráfico mais condizente com o que é encontrado na realidade, ademais permite uma comparação justa com os resultados da concentração dos efluentes.

Contudo, deve ser ressaltado que ajustes em relação a dois parâmetros, sendo eles: N-Amoniacal e Fósforo Total devem ser feitos, já que ambos não apresentaram resultados satisfatórios em relação à concentração apontada em campo.

Para a validação desse modelo, os testes mostraram que para os coeficientes bioquímicos podem ser adotados tanto os valores típicos quanto os valores mínimos estipulados pela literatura, já que ambos apresentam resultados visualmente semelhantes.

Das análises efetuadas, as que apresentaram valores mais próximos das amostras reais da lagoa de Pedrelli (1997) foram a Alcalinidade e pH. A que apresentou valor satisfatório em relação a esse trabalho foi o DQO solúvel. Enquanto os parâmetros DQO, $\mathrm{NTK}, \mathrm{NH}_{4}$ e $\mathrm{O}_{2}$ tiveram resultados na simulação insatisfatórios, esses podem ser explanados devido a três condições que são adotadas no modelo de Fritz (1985) que se diferem da realidade:

1. Não considerar a variabilidade dos parâmetros característicos do afluente; 
2. Não considerar a variação do volume da lagoa, aplicando o conceito de escoamento permanente;

3. Não considerar o efeito da estratificação térmica na coluna líquida.

Além dessas condições, também deve ser considerado o fato das amostras serem pontuais, enquanto para a análise correta essas deveriam ser coletas compostas.

Em relação à validação, a pergunta era: "Esse modelo é útil?". Ela também pode ser respondida de maneira afirmativa, mas com muitos "ses". O modelo é útil para uma lagoa facultativa, se ela operar como um reator de mistura completa, se as suas amostras forem compostas e se não existir estratificação da coluna líquida.

Portanto recomenda-se uma nova validação utilizando dados de uma lagoa facultativa que opere sob essas condições e sejam coletados corretamente. Pois simular com dados incorretos gerarão resultados incorretos, ou seja, "Se lixo entra, então lixo sai" (GIGO).

\section{REFERÊNCIAS}

[1] BRASIL. Ministério das Cidades. Secretaria Nacional de Saneamento Ambiental - SNSA. Sistema Nacional de Informações sobre Saneamento: Diagnóstico dos Serviços de Água e Esgotos - 2015. Brasília: SNSA/MCIDADES, 2017. 212 p. : il.

[2] CHWIF, L.; MEDINA, A. C. Modelagem e simulação de eventos discretos: teoria \& prática. São Paulo: Ed. dos Autores, 2006. 254 p.

[3] FERZIGER, J. H.; PERIC, M. Computational Methods for Fluid Dynamics. 3 a ed. Berlin; Heidelberg; New York; Barcelona; Hong Kong; London; Milan; Paris; Tokyo: Springer, 2002. 423 p.

[4] FORD, A. Modeling the Environment: An Introduction to System Dynamics Modeling of Environmental Systems. Washington; Covelo: Island Press, 1999. 401 p.

[5] FRITZ, J. J. Mathematical Models for Waste Stabilisation Ponds. In: JORGENSEN, S. E.; GROMIEC, M.J. Mathematical Models in Biological Wastewater Treatment. ELSEVIER, New York. 1985. p. 169-241.

[6] INSTITUTO BRASILEIRO DE GEOGRAFIA E ESTATÍSTICA (IBGE). Estimativas populacionais para os municípios e para as Unidades da Federação brasileiros em 01.07.2016. Atendendo ao dispositivo legal, Lei no 8443 , de 16 de julho de 1992, no artigo 102, o IBGE fez publicar no Diário Oficial da União, em 30 de agosto de 2016, as estimativas de população para os municípios e para as Unidades da Federação brasileiros, com data de referência em 1o de julho de 2016. A Lei complementar no 143, de 17 de julho de 2013, alterou o art. 102 da Lei no 8443, revogando os parágrafos $1^{\circ}$ e $2^{\circ}$, que estabelecia o prazo de 20 dias após a publicação das estimativas no Diário Oficial da União para apresentação de reclamações ao IBGE. Diário Oficial da União, Poder Executivo, Brasília, DF, 30 Ag. 2016.

[7] KELLNER, E.; MOREIRA, J. F. V.; PIRES, E. C. Influência da estratificação térmica no volume útil e no comportamento hidrodinâmico de lagoa de estabilização: determinação experimental e teórica. Engenharia Sanitária e Ambiental: Rio de Janeiro, v. 14, n. 1: 129-138, jan/mar 2009. Disponível em: <http://dx.doi.org/10.1590/S141341522009000100014>. Acesso em: 11 Jun. 2018.

[8] KELLNER, E.; PIRES, E. C. Lagoas de estabilização: projeto e operação. Rio de Janeiro: ABES, 1998. 244p.

[9] The influence of thermal stratification on the hydraulic behavior of waste stabilization ponds. Water Science \& Technology: Londres, v. 45, n. 1: 41-48, jan 2002. Disponível em: <http://wst.iwaponline.com/content/45/1/41>. Acesso em: 11 Jun. 2018.

[10] MARA, D.; HORAN, N. Handbook of water and wastewater microbiology. 1 ed. London: Academic Press, 2003, $832 \mathrm{p}$.

[11] METCALF \& EDDY, INC. Wastewater engineering treatment and reuse. $4^{\mathrm{a}} \mathrm{e}$ ed. New York: McGrawHill, 2003. 1819 p.

[12] PEDRELLI, T. D. Avaliação do Sistema de Lagoas de Estabilização para o Tratamento das Águas Residuárias de Balneário Camboriú/SC. 1997. 154 p. Dissertação (Mestrado em Engenharia Ambiental) - Programa de PósGraduação em Engenharia Ambiental, UFSC, Florianópolis, 1997.

[13] SILVA, S. A. Tratamento de Esgotos Domésticos em Lagoas de Estabilização do Nordeste do Brasil. Universidade Federal da Paraíba - UFPB. Tese. 1982. 249 p.

[14] TRUPPEL, A. Redução de Odores de uma Lagoa de Estabilização de Esgoto Sanitário e Avaliação da Qualidade de seu Efluente. 188 p. 2002. Dissertação (Mestrado em Engenharia Ambiental) - Programa de Pós-Graduação em Engenharia Ambiental, UFSC, Florianópolis, 1997.

[15] VON SPERLING, M. Biological Wastewater Treatment Series: Waste Stabilization Ponds. Volume 3. London: IWA Publishing, 2007. $162 \mathrm{p}$. 


\section{Capítulo 9}

Toxicidade do efluente e consumo hídrico e energético no tingimento de poliamida

\section{Aline Viana de Morais}

Camila Gomes Melo

Vanessa Silva Granadeiro Garcia

Maria da Conceição Costa Pereira

Jorge Marcos Rosa

Sueli Ivone Borrely

Resumo: 0 uso racional da água é imprescindível no setor industrial e deste modo necessita de tecnologia e esforços que permitam o reuso desse recurso natural. 0 estudo concentrou-se na determinação do consumo hídrico e energético durante o tingimento da poliamida, bem como na avaliação do efeito tóxico do efluente para o microcrustáceo Daphnia similis. 0 efluente pode ser considerado como muito tóxico tendo em vista que a CE50 foi $0,61 \pm 0,21(\%, v / v)$ após 48 horas de exposição. Conforme orientação da Resolução CONAMA 430/2011 o efluente deve ser tratado em nível tal que não induza toxicidade quando lançado no corpo receptor. Buscas por tecnologias que permitam o reúso e a melhoria dos efluentes também são necessários nessa atividade industrial.

Palavras-chave: Indústria têxtil; corantes; efluente; Daphnia similis; toxicidade. 


\section{INTRODUÇÃO}

A atividade têxtil no Brasil representa cerca de U\$ 45 bilhões, o equivalente a $7 \%$ do valor total da produção da indústria de transformação brasileira. Os empregos gerados pela cadeia têxtil alcançaram 1,5 milhão em 2017, cerca de 18,7\% da produção industrial total (Prado, 2019).

Apesar de sua importância para os países em desenvolvimento, a fabricação de têxteis é uma questão complexa em relação ao meio ambiente, ao uso da água e à poluição resultante para os sistemas de recebimento de água. 0 processamento têxtil consiste em várias operações, como limpeza, lavagem, branqueamento, tingimento e estampagem. Portanto, o efluente têxtil é caracterizado pela presença de uma importante variedade de elementos, estes advindos dos mais diversos processos de produção que empregam recursos hídricos. Dentre estes elementos, os corantes implicam em um forte causador de impactos ambientais significativos quando não tratados adequadamente (Morais et al., 2014; Santos et al., 2017). A descarga direta do efluente têxtil colorido nos corpos de água, na maioria das vezes, tratado de maneira ineficiente, afeta negativamente o aspecto estético, a transparência da água e o teor de oxigênio dissolvido (Martin et al., 2017; Lafi et al., 2018). Os resultados desse tipo de descarte são os danos à biota aquática, além de outros prejuízos.

Em busca de uma produção mais limpa, novos tecidos e fibras foram obtidos como fibras artificiais de Lyocell (Paulitz et al., 2017), a aplicação de líquido iônico em tingimento (Bianchini et al., 2015; Meksi e Moussa, 2017). Novos corantes foram obtidos de fontes renováveis (Shahid-ul-Islam e Sun, 2017), a imobilização de catalisador e desenvolvimento para a aplicação de enzimas para processamento têxtil (Chu et al., 2018; Madhu e Chakraborty, 2017), coloração mais limpa com corante reativo usando um processo pad-batch-steam (Shu et al., 2018), bem como a desinfecção de têxteis usando plasma de baixa temperatura (Szulc et al., 2018). As tecnologias, idéias e ações para uma melhor gestão ambiental no setor têxtil têm que alcançar a redução da descarga de poluição, principalmente, para efluentes líquidos, devido à demanda e escassez de água em diferentes áreas setores, e o endurecimento da legislação ambiental sobre os efluentes gerados pela indústria têxtil (Hossain et al., 2018).

Vários métodos e processos para o tratamento de águas residuais têxteis foram estudados, como sistema de membrana (Ghaffar et al., 2018; Han et al., 2017, 2018; Li et al., 2017), ultrafiltração (Jiang et al., 2018), adsorção (Vanaamudan, Chavada e Padmaja, 2016; Zhang et al., 2018; Zhao et al., 2015), processo híbrido (Lin et al., 2015; Rosales et al., 2018), oxidação eletroquimicamente avançada (Silva et al., 2018), processos biológicos (Assémian et al., 2018; Das e Mishra, 2017), degradação de corantes do solo por plantas ornamentais (Chandanshive et al., 2018) e utilização de efluente têxtil como nutriente para Chlorella variabilis (Bhattacharya et al., 2017).

0 monitoramento da carga tóxica de efluentes é hoje uma ação obrigatória para a proteção dos recursos hídricos. Como exemplo, três tipos de corantes reativos foram avaliados quanto à toxicidade por Baumer et al. (Duarte Baumer et al., 2018). Os autores aplicaram um sistema oxidativo incluindo sistemas enzimáticos como alternativa para o tratamento de efluentes têxteis. Porém, durante seus estudos os processos oxidativos foram capazes de degradar produtos orgânicos, mas a toxicidade não foi reduzida (para efeitos agudos e crônicos - Daphnia magna e Vibrio fischeri). Eles também obtiveram bons resultados para a descoloração. Croce et al. (Croce et al., 2017) investigaram a toxicidade aquática de 42 corantes comerciais com a aplicação de ferramentas in silico. Ensaios ecotoxicológicos de exposição aguda e de longa duração com Daphnia magna e Raphidocelis subcapitata foram aplicados para avaliar o potencial impacto desses produtos. Os autores concluíram que apenas 9 formulações apresentaram toxicidade inferior a $100 \mathrm{mg} \mathrm{L}-1$ para Daphnia magna enquanto 30 corantes foram tóxicos para a alga Raphidocelis subcapitata.

A avaliação da toxicidade do efluente de tingimento têxtil e sua possível relação com a demanda química de oxigênio foi estudada por Liang et al. (Liang et al., 2017), testando a toxicidade aguda com a utilização dos organismos Vibrio fischeri e Desmodesmus subspicatus. Os autores identificaram correlação positiva com a DQO em diferentes efluentes de tingimento têxtil, com valores de R2 superiores a 0,84.

Devido a estes fatos, este estudo abordou a toxicidade aguda do efluente gerado pelo tingimento de uma cor selecionada do Caderno de Tendências Primavera-Verão 2018, do SENAI-SP. 0 tingimento da cor selecionada, Pantone 19-2024, foi executado em tecido de fibras de poliamida (PA), a fibra mais utilizada no setor de vestuário para linha praia e lingerie (Prado, 2018). Foram calculados o consumo hídrico, o consumo energético e a toxicidade aguda do efluente, pela exposição de dafnídeos. 


\section{METODOLOGIA}

\subsection{EFLUENTE}

O efluente real foi obtido através de tingimento (HT Mathis Alt-1) efetuado em relação de banho (RB) 1:10, de acordo com orientações do fabricante dos corantes, em tecido de malha de PA com gramatura igual a $150 \mathrm{~g} \mathrm{~m}-2$.

Os reagentes utilizados no processo foram 0,6 g L-1 de ácido acético 98\% e 1,0 g L-1 de sulfato de amônio (Labsynth); 1,0 g L-1 igualizante, 2\% de fixador, 0,659\% de Acid Orange 67, 0,34\% de Acid Red 299 e 0,213\% de Acid Blue 113 (Archroma). 0 processo encontra-se demonstrado na Figura 1, onde se observa o consumo de água, o tempo de processo e as etapas onde é necessário aquecimento.

Figura 1. Etapas do processo de coloração do tecido

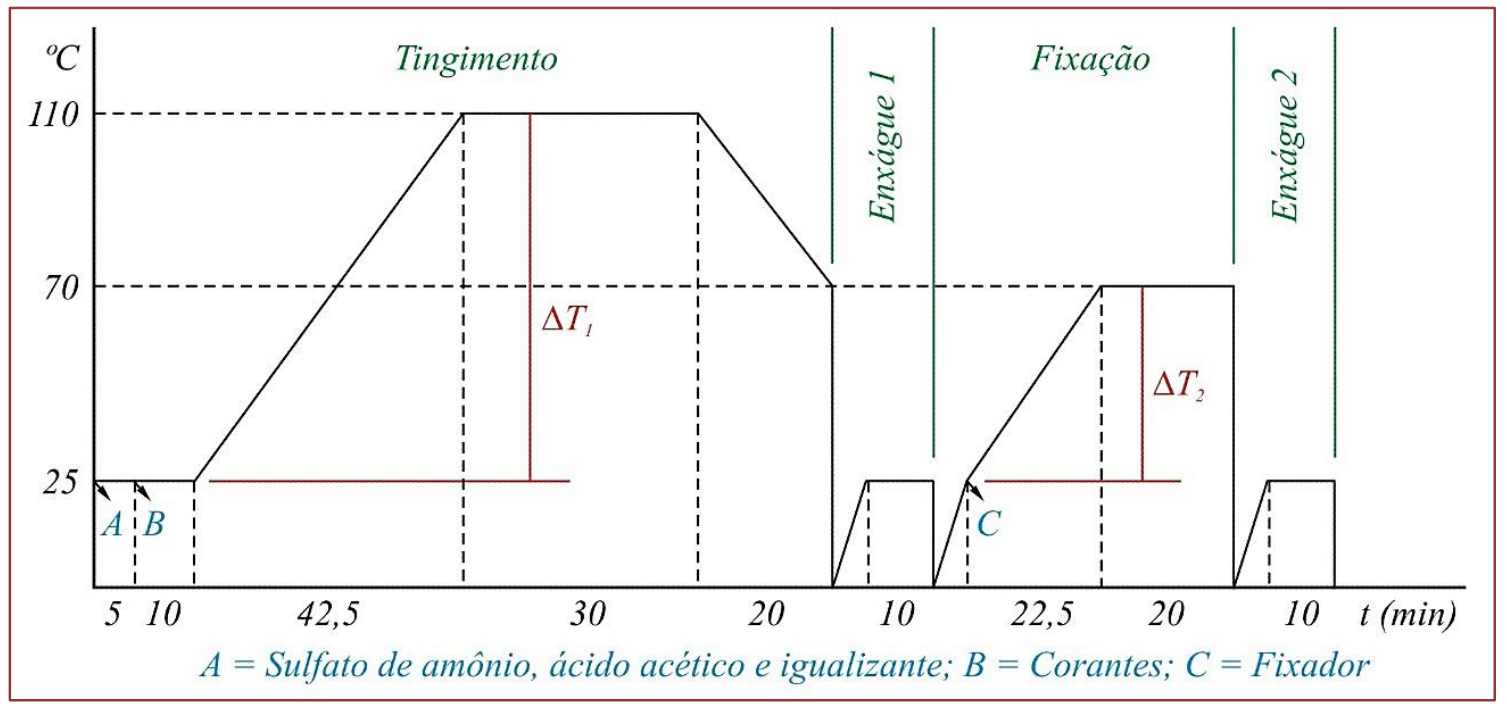

\subsection{CONSUMO HÍDRICO E ENERGÉTICO}

0 consumo de água, adotando-se $10,0 \mathrm{~L} \mathrm{~kg}^{-1}$ (RB 1:10) para cada etapa de processo, foi calculado pela equação 1.

$$
V=\left(E_{1}+E_{2}+E_{3}+E_{4}\right)
$$

Onde $\mathrm{V}=\mathrm{L} \mathrm{kg}^{-1} ; \mathrm{E}_{1}=$ tingimento; $\mathrm{E}_{2}=$ enxágüe $1 ; \mathrm{E}_{3}=$ fixação e $\mathrm{E}_{4}=$ enxágüe 2 .

Para calcular o consumo teórico de energia elétrica para cada quilograma de substrato beneficiado em equipamento industrial (Jet HT Riviera Eco, capacidade de $50 \mathrm{~kg}$ e potência instalada igual a 7,4 kWh), calculou-se o tempo de processo de tingimento e aplicou-se a equação 2.

$$
\mathrm{Q}_{1}=\mathrm{kWh} \cdot \mathrm{t} \cdot 1,20 \cdot 10^{3}
$$

Onde $\mathrm{Q}_{1}=\mathrm{J} \mathrm{kg}^{-1} ; \mathrm{t}=$ tempo de processo em minutos.

Adotou-se massa específica da água igual a $1,0 \mathrm{~g} \mathrm{~cm}^{-3}$ para calcular o consumo teórico de energia térmica para cada quilograma de substrato beneficiado, aplicando-se a equação 3.

$$
\mathrm{Q}_{2}=\Delta \mathrm{T} \cdot \mathrm{CpH}_{2} \mathrm{O} \cdot \mathrm{mH}_{2} \mathrm{O} \cdot 10^{-3}
$$

Onde $\mathrm{Q}_{2}=\mathrm{J} \mathrm{kg}^{-1} ; \mathrm{T}$ = temperatura em Kelvin; $\mathrm{Cp}=$ calor específico da água em J kg-1 $\mathrm{K}^{-1} ; \mathrm{m}=$ massa da água em gramas. 


\subsection{ENSAIOS DE TOXICIDADE}

O efluente foi coletado em todas as etapas do processo (tingimento, enxágüe, fixação e enxágüe), e armazenado em recipiente de polietileno, refrigerado e enviado ao laboratório para execução dos ensaios de toxicidade. Para a coleta e armazenamento do efluente foram seguidas as recomendações da ABNT (2007). O ensaio de toxicidade aguda com o microcrustáceo Daphnia similis foi realizado com base na norma ABNT NBR n 12713/2016, no Laboratório de Ensaios Biológicos e Ambientais (LEBA), localizado no Centro de Tecnologia das Radiações (CETER) do Instituto de Pesquisas Energéticas e Nucleares (IPEN).

A partir de um cultivo do próprio laboratório foram obtidos organismos jovens de Daphnia similis (idade entre 6 e 24h) para a devida exposição às amostras de efluente têxtil. A metodologia de ensaio seguiu a ABNT, com exposição de 48 horas, a 20oC, na ausência de luz e de alimentação. A água utilizada na diluição do efluente foi a mesma empregada no cultivo dos organismos-teste (água de reservatório com ajuste de dureza para $44 \pm 2 \mathrm{mg} \mathrm{L}-1$ CaC03). Trimmed Spearman Karber foi o teste estatístico aplicado para o cálculo da CE50 (concentração efetiva mediana que resultou na imobilidade de $50 \%$ dos organismos). Essa análise foi realizada em triplicata.

\section{RESULTADOS E CONCLUSÃO}

\subsection{CONSUMO HÍDRICO E ENERGÉTICO}

Os valores dos consumos energéticos (elétrico e térmico) e hídrico, obtidos para o processamento de um quilograma de substrato, encontram-se descritos na Tabela 1.

Tabela 1. Consumo de água, energia elétrica e energia térmica por quilograma.

\begin{tabular}{|c|c|c|c|}
\multirow{2}{*}{ Consumo/kg } & \multicolumn{2}{|c|}{ Energia (J) } \\
\cline { 2 - 4 } & 40 & Elétrica & Térmica \\
\cline { 2 - 4 } & $4,42 \cdot 10^{6}$ & $2,80 \cdot 10^{3}$ \\
\hline
\end{tabular}

De acordo com a Organização das Nações Unidas (ONUBR, 2018), a quantidade necessária diária de água por pessoa é de 20 litros. 0 consumo de água necessário para o tingimento de um quilograma de tecido de PA, tingido na cor Pantone 19-2024, é o dobro desta quantidade, ou seja, são gastos 40 litros para cada quilograma tingido. 0 consumo de energia elétrica necessário para o tingimento da cor em estudo seria equivalente a um banho de aproximadamente seis horas de duração (chuveiro com $4000 \mathrm{~W}$ de potência).

\subsection{TOXICIDADE}

Os resultados dos ensaios de toxicidade foram organizados na Tabela 2, podendo ser observada elevada toxicidade da amostra quando a concentração < 1\% resultou em 100\% de imobilidade dos organismos expostos. A amostra pode ser considerada como muito tóxica para Daphnia similis, expostas por 48 horas ao efluente estudado.

Tabela 2. Toxicidade aguda em efluente empregando Daphnia similis

\begin{tabular}{|c|c|c|}
\hline \multirow{6}{*}{ Daphnia similis } & $\mathrm{CE}_{50}(\%)$ & Intervalo de confiança \\
\hline & 0,52 & $(0,20-1,37)$ \\
\hline & 0,85 & $(0,77-0,93)$ \\
\hline & 0,46 & $(0,11-1,19)$ \\
\hline & 0,61 & \multirow{2}{*}{ - } \\
\hline & $0,61 \pm 0,21^{*}$ & \\
\hline
\end{tabular}

*Média das $\mathrm{CE}_{50}$ com desvio padrão (0,61\% de efluente causando imobilidade a 50\% das Daphnia similis expostas por 48h) 
Como conclusão deste estudo devemos destacar que somente neste processo do presente estudo foram empregados três corantes distintos, o Acid Orange 67, o Acid Red 299 e o Acid Blue 113, além de outros tantos produtos químicos. Também foi possível observar uma toxicidade elevada no efluente, o que significa que esses ensaios representam a somatória de efeitos sinérgicos da mistura de produtos contidos no efluente, e que ao pretender proteger o ambiente aquático desse tipo de descartes, os ensaios ecotoxicológicos destacam-se dentre as ferramentas essenciais.

\section{REFERÊNCIAS}

[1] ABNT - ASSOCIAÇÃO BRASILEIRA DE NORMAS TÉCNICAS. NBR 12713:2016. ECotoxicologia AquÁtica TOXICIDADE AGUdA - MÉTODO DE ENSAIO Com DAPHNIA SPP (CRUSTACEA, CladocerA).

[2] ABNT - ASSOCIAÇÃO BRASILEIRA DE NORMAS TÉCNICAS. NBR 15469:2007. Ecotoxicologia aquática Preservação e preparo de amostras.

[3] ASSÉMIAN, A. S.; KOUASSI, K. E.; ZOGBÉ, A. E.; ADOUBY, K.; DROGUI, P. In-situ generation of effective coagulant to treat textile bio-refractory wastewater: Optimization through response surface methodology. Journal of Environmental Chemical Engineering, v. 6, n. 4, p. 5587-5594, 1 ago. 2018.

[4] AZIZ, H. A.; RAZAK, M. H. A.; RAHIM, M. Z. A.; KAMAR, W. I. S. W.; ABU AMR, S. S.; HUSSAIN, S.; LEEUWEN, J. VAN. Evaluation and comparison the performance of titanium and zirconium(IV) tetrachloride in textile wastewater treatment. Data in Brief, v. 18, p. 920-927, 2018.

[5] BHATTACHARYA, S.; PRAMANIK, S. K.; GEHLOT, P. S.; PATEL, H.; GAJARIA, T.; MISHRA, S.; KUMAR, A. Process for Preparing Value-Added Products from Microalgae Using Textile Effluent through a Biorefinery Approach. ACS Sustainable Chemistry \& Engineering, v. 5, n. 11, p. 10019-10028, 6 nov. 2017.

[6] BIANCHINI, R.; CEVASCO, G.; CHIAPPE, C.; POMELLI, C. S.; RODRÍGUEZ DOUTON, M. J. Ionic Liquids Can Significantly Improve Textile Dyeing: An Innovative Application Assuring Economic and Environmental Benefits. ACS Sustainable Chemistry \& Engineering, v. 3, n. 9, p. 2303-2308, 8 set. 2015.

[7] BILIŃSKA, L.; BLUS, K.; GMUREK, M.; LEDAKOWICZ, S. Coupling of electrocoagulation and ozone treatment for textile wastewater reuse. Chemical Engineering Journal, v. 358, p. 992-1001, 15 fev. 2019.

[8] CHANDANSHIVE, V. V.; KADAM, S. K.; KHANDARE, R. V.; KURADE, M. B.; JEON, B.-H.; JADHAV, J. P.; GOVINDWAR, S. P. In situ phytoremediation of dyes from textile wastewater using garden ornamental plants, effect on soil quality and plant growth. Chemosphere, v. 210, p. 968-976, 1 nov. 2018.

[9] CHU, Y.; CORRIGAN, N.; WU, C.; BOYER, C.; XU, J. A Process for Well-Defined Polymer Synthesis through Textile Dyeing Inspired Catalyst Immobilization. ACS Sustainable Chemistry \& Engineering, 17 set. 2018.

[10] CROCE, R.; CINÀ, F.; LOMBARDO, A.; CRISPEYN, G.; CAPPELLI, C. I.; VIAN, M.; MAIORANA, S.; BENFENATI, E.; BADERNA, D. Aquatic toxicity of several textile dye formulations: Acute and chronic assays with Daphnia magna and Raphidocelis subcapitata. Ecotoxicology and Environmental Safety, v. 144, p. 79-87, 1 out. 2017.

[11] DAS, A.; MISHRA, S. Removal of textile dye reactive green-19 using bacterial consortium: Process optimization using response surface methodology and kinetics study. Journal of Environmental Chemical Engineering, v. 5, n. 1, p. 612-627, 1 fev. 2017.

[12] DUARTE BAUMER, J.; VALÉRIO, A.; SOUZA, S. M. A. G. U. DE; ERZINGER, G. S.; FURIGO, A.; SOUZA, A. A. U. DE. Toxicity of enzymatically decolored textile dyes solution by horseradish peroxidase. Journal of Hazardous Materials, v. 360, p. 82-88, 15 out. 2018.

[13] FALCO, F. DE et al. Evaluation of microplastic release caused by textile washing processes of synthetic fabrics. Environmental Pollution, v. 236, p. 916-925, 1 maio 2018.

[14] GHAFFAR, A.; ZHANG, L.; ZHU, X.; CHEN, B. Porous PVdF/GO Nanofibrous Membranes for Selective Separation and Recycling of Charged Organic Dyes from Water. Environmental Science \& Technology, v. 52, n. 7, p. 4265-4274, 3 abr. 2018.

[15] HAN, G.; CHUNG, T.-S.; WEBER, M.; MALETZKO, C. Low-Pressure Nanofiltration Hollow Fiber Membranes for Effective Fractionation of Dyes and Inorganic Salts in Textile Wastewater. Environmental Science \& Technology, v. 52, n. 6, p. 3676-3684, 20 mar. 2018.

[16] HAN, G.; FENG, Y.; CHUNG, T.-S.; WEBER, M.; MALETZKO, C. Phase Inversion Directly Induced Tight Ultrafiltration (UF) Hollow Fiber Membranes for Effective Removal of Textile Dyes. Environmental Science \& Technology, v. 51, n. 24, p. 14254-14261, 19 dez. 2017.

[17] HOSSAIN, M. S.; DAS, S. C.; ISLAM, J. M. M.; MAMUN, M. A. AL; KHAN, M. A. Reuse of textile mill ETP sludge in environmental friendly bricks - effect of gamma radiation. Radiation Physics and Chemistry, v. 151, p. 77-83, 2018.

[18] JEMEC, A.; HORVAT, P.; KUNEJ, U.; BELE, M.; KRŽAN, A. Uptake and effects of microplastic textile fibers on 
freshwater crustacean Daphnia magna. Environmental Pollution, v. 219, p. 201-209, 1 dez. 2016.

[19] JIANG, M.; YE, K.; DENG, J.; LIN, J.; YE, W.; ZHAO, S.; BRUGGEN, B. VAN DER. Conventional Ultrafiltration As Effective Strategy for Dye/Salt Fractionation in Textile Wastewater Treatment. Environmental Science \& Technology, v. 52, n. 18, p. 10698-10708, 18 set. 2018.

[20] LAFI, R.; GZARA, L.; LAJIMI, R. H.; HAFIANE, A. Treatment of textile wastewater by a hybrid ultrafiltration/electrodialysis process. Chemical Engineering and Processing - Process Intensification, v. 132, p. 105113, 1 out. 2018.

[21] LI, M.; YAO, Y.; ZHANG, W.; ZHENG, J.; ZHANG, X.; WANG, L. Fractionation and Concentration of High-Salinity Textile Wastewater using an Ultra-Permeable Sulfonated Thin-film Composite. Environmental Science \& Technology, v. 51, n. 16, p. 9252-9260, 15 ago. 2017.

[22] LIANG, J.; NING, X.; KONG, M.; LIU, D.; WANG, G.; CAI, H.; SUN, J.; ZHANG, Y.; LU, X.; YUAN, Y. Elimination and ecotoxicity evaluation of phthalic acid esters from textile-dyeing wastewater. Environmental Pollution, v. 231, p. 115122, 1 dez. 2017.

[23] LIN, J. et al. Toward Resource Recovery from Textile Wastewater: Dye Extraction, Water and Base/Acid Regeneration Using a Hybrid NF-BMED Process. ACS Sustainable Chemistry \& Engineering, v. 3, n. 9, p. 1993-2001, 8 set. 2015.

[24] MADHU, A.; CHAKRABORTY, J. N. Developments in application of enzymes for textile processing. Journal of Cleaner Production, v. 145, p. 114-133, 1 mar. 2017.

[25] MARTINS, T. C.; PALÁCIO, S. M.; VEIT, M. T.; FAGUNDES-KLEN, M. R.; ALMEIDA, A. A.; MiCHELIM, H. J.; VICENTINO, R. C.: Tratamento de efluente têxtil por processo fenton-like usando ferro zero valente. Química Têxtil 128, pp. 18-34, 2017.

[26] MEKSI, N.; MOUSSA, A. A review of progress in the ecological application of ionic liquids in textile processes. Journal of Cleaner Production, v. 161, p. 105-126, 10 set. 2017.

[27] MORAIS, A.V.; ROSA, J.M.; BADARÓ-PEDROSO, C.; BORRELY, S.I.: Contribuição da condutividade à toxicidade de um efluente têxtil avaliado por meio de ensaios ecotoxicológicos com invertebrados de água doce e estuarino. Anais do Congresso Nacional de Meio Ambiente de Poços de Caldas, v.6, n.1, 2014.

[28] ONUBR - Nações Unidas no Brasil. A ONU e a água. Disponível em: https://nacoesunidas.org/acao/agua. Acesso em 07 de julho de 2018.

[29] PAULITZ, J.; SIGMUND, I.; KOSAN, B.; MEISTER, F. Lyocell fibers for textile processing derived from organically grown hemp. Procedia Engineering, v. 200, p. 260-268, 1 jan. 2017.

[30] PRADO, M. V. Sectorial Report of Brazilian Textile Industry. São Paulo: [s.n.].

[31] PRADO, M.V.: Brasil Têxtil - Relatório Setorial da Indústria Têxtil Brasileira. Instituto de Estudos e Marketing Industrial LTDA - IEMI, 156 p., 2018.

[32] ROSALES, E.; ANASIE, D.; PAZOS, M.; LAZAR, I.; SANROMÁN, M. A. Kaolinite adsorption-regeneration system for dyestuff treatment by Fenton based processes. Science of The Total Environment, v. 622-623, p. 556-562, 1 maio 2018.

[33] SANTOS, R. F.; CORREA, V. H. M.; MARANGONI, C.; AGUIAR, C. R. L.: Influência da ativação química com NaOH e $\mathrm{CH} 3 \mathrm{COOH}$ em carvão ativado de casca de coco na adsorção do corante reativo Remazol Preto 5. Química Têxtil 128, pp. 6-16, 2017.

[34] SHAHID-UL-ISLAM; SUN, G. Thermodynamics, Kinetics, and Multifunctional Finishing of Textile Materials with Colorants Extracted from Natural Renewable Sources. ACS Sustainable Chemistry \& Engineering, v. 5, n. 9, p. 7451-7466, 5 set. 2017.

[35] SHU, D.; FANG, K.; LIU, X.; CAI, Y.; ZHANG, X.; ZHANG, J. Cleaner coloration of cotton fabric with reactive dyes using a pad-batch-steam dyeing process. Journal of Cleaner Production, v. 196, p. 935-942, 20 set. 2018.

[36] SILVA, L. G. M.; MOREIRA, F. C.; SOUZA, A. A. U.; SOUZA, S. M. A. G. U.; BOAVENTURA, R. A. R.; VILAR, V. J. P. Chemical and electrochemical advanced oxidation processes as a polishing step for textile wastewater treatment: A study regarding the discharge into the environment and the reuse in the textile industry. Journal of Cleaner Production, v. 198, p. 430-442, 10 out. 2018.

[37] SZULC, J.; URBANIAK-DOMAGAŁA, W.; MACHNOWSKI, W.; WRZOSEK, H.; ŁĄCKA, K. Low temperature plasma for textiles disinfection. International Biodeterioration \& Biodegradation, v. 131, p. 97-106, 1 jul. 2018.

[38] VANAAMUDAN, A.; CHAVADA, B.; PADMAJA, P. Adsorption of reactive blue 21 and reactive red 141 from aqueous solutions onto hydrotalcite. Journal of Environmental Chemical Engineering, v. 4, n. 3, p. 2617-2627, 1 set. 2016.

[39] ZHANG, H.; LI, P.; WANG, Z.; CUI, W. W.; ZHANG, YANG; ZHANG, YING; ZHENG, S.; ZHANG, YI. Sustainable 
Disposal of Cr(VI): Adsorption-Reduction Strategy for Treating Textile Wastewaters with Amino-Functionalized Boehmite Hazardous Solid Wastes. ACS Sustainable Chemistry \& Engineering, v. 6, n. 5, p. 6811-6819, 7 maio 2018.

[40] ZHAO, F.; REPO, E.; YIN, D.; MENG, Y.; JAFARI, S.; SILLANPÄÄ, M. EDTA-Cross-Linked $\beta$-Cyclodextrin: An Environmentally Friendly Bifunctional Adsorbent for Simultaneous Adsorption of Metals and Cationic Dyes. Environmental Science \& Technology, v. 49, n. 17, p. 10570-10580, 1 set. 2015. 


\section{Capítulo 10}

Geoquímica orgânica do sistema estuarino tropical Sergipe-Poxim: Fontes de matéria orgânica e riscos ecológicos

\section{Michel Rubens dos Reis Souza \\ Ewerton Santos \\ Marcelo da Rosa Alexandre}

Resumo: 0 sistema estuarino Sergipe-Poxim está localizado na área urbana da cidade de Aracaju,Nordeste do Brasil. Este sistema tem importância socioeconômica, porém, sofre forte contribuição negativa, sendo conectado a canais de esgoto in natura. Além disso, é ligado ao Oceano Atlântico, no qual ocorre exploração de petróleo. 0 objetivo deste trabalho foi avaliar a geoquímica orgânica deste sistema através de marcadores lipídicos esteróis e hidrocarbonetos policíclicos aromáticos (HPA) nas matrizes água e sedimento superficiais, e ostras (Crassostrea sp.) em dois períodos (março e agosto, 2017). No sedimento, observou-se um predomínio do esterol biogênico $\beta$-sitosterol em ambos os períodos. Em todas as estações amostrais, os níveis de coprostanol foram > $100 \mathrm{ng} \mathrm{g}^{-1}$, indicativo de contaminação fecal. Razões diagnósticas entre esteróis confirmaram o predomínio de fontes de esgoto. Já os HPA foram determinados nas três matrizes. Em todas, os HPA apresentaram-se em baixas concentrações, sendo a pirogênica a fonte principal. Os índices de riscoecológico dos HPA para água e sedimento foram, em alguns casos, moderados, apresentando-se em níveis de alerta à saúde dos organismos, sendo que as ostras bioacumularam preferencialmente HPA de 2-4 anéis, entre eles o pireno, muito tóxico a bivalves. Portanto, este sistema necessita urgentemente de socorro.

Palavras-Chave: Coprostanol, HPA, poluição 


\section{INTRODUÇÃO}

O sistema estuarino Sergipe-Poxim é um bom exemplo para entender a relação entre as atividades humanas e suas influências no ecossistema. Localizado no Nordeste do Brasil, este ambiente aquático é um dos principais sistemas estuarinos do estado de Sergipe e uma importantefonte econômica para a cidade de Aracaju (Souza et al., 2018; Nilin et al., 2019). Não obstante, as atividades antropogênicas podem representar forte influência na dinâmica fluvial deste ambiente.

Os marcadores moleculares servem para identificar a condição ambiental atual ou reconstruira identidade histórica da microrregião, caracterizar a natureza da matéria orgânica (MO) e fornecer dados sobre mudanças paleoclimáticas (Frena et al., 2019). Alguns destes, tais como os 16 hidrocarbonetos policíclicos aromáticos (HPA) prioritários (Souza et al., 2018), são poluentes tóxicos e seu diagnóstico pode indicar problemas de saúde observados na biota de ecossistemas, entendendo, por exemplo, o sumiço de organismos mais sensíveis (Ramdine et al., 2012). Os esteróis são usados para identificar atividades biogênicas ou antropogênicas de poluição fecal (Frena et al., 2019). Portanto, ambos os grupos podem caracterizar fontes de $\mathrm{MO}$, tanto marinhas quanto terrígenas.

A utilização de moluscos bivalves traz vantagens na avaliação da poluição no ambiente aquático tais como: detecção dos poluentes, biodisponibilidade e acúmulo, e os efeitos tóxicos (Xieet al., 2017). As ostras, por exemplo, têm sido postuladas como biomonitores ideais devido à sua ampla distribuição geográfica e sensibilidade a poluentes ambientais. Na literatura registra-se que elas têm baixa capacidade metabólica e alta carga corporal para poluente químicos, o que lhes permite acumular poluentes através da exposição direta e indireta no meio ambiente (Xie et al., 2017). No entanto, não se pode desprezar as matrizes ambientais água e sedimento, pois estas trazem informações relevantes para entender o ambiente, através da detecção de marcadores moleculares. A cidade de Aracaju, por exemplo, apresenta uma significativa concentração populacional na zona costeira (Nilin et al., 2019). No entanto, pouco se sabe sobre as atuais condições de saúde de estuários localizados nesta cidade e, no sistema estuarino SergipePoxim, a distribuição de marcadores moleculares é pouco conhecida. Portanto, esta pesquisa fundamentou-se na Química Analítica Ambiental e Análise de Traços. Neste sentido, delineou-se oobjetivo central de avaliar compostos lipídicos em matrizes ambientais. Para tanto, o foco central esteve na avaliação da qualidade dos sedimentos, águas e ostras (Crassostrea sp.) coletados no sistema estuarino Sergipe-Poxim, por meio da identificação de marcadores geoquímicos esteróis e HPA, fontes e riscos ecológicos.

\section{MATERIAL E MÉTODOS}

Neste trabalho, foram coletados sedimentos superficiais (33 amostras), águas superficiais ( 30 amostras) e ostras (Crassostrea sp.) ( 9 amostras, 1 amostra $=12$ indivíduos), em dois períodos, emmarço/2017 (maré enchente) e agosto/2017 (maré vazante), em aproximadamente 5,3 Km de extensão ( 2 min de navegação entre as estações), a partir do canal da Avenida Anízio Azevedo (S2) até a ponte Gilberto Vila-Nova de Carvalho (S15). (Figura 1). As amostras de sedimento (S), água (W) e ostra (0) foram denominadas pelas respectivas letras, número da estação e período decoleta, sendo a letra "d" subscrita significa período seco e a letra " $r$ " subscrita significa período chuvoso.

Figura 1. Mapa da área de estudo mostrando as estações de amostragem.

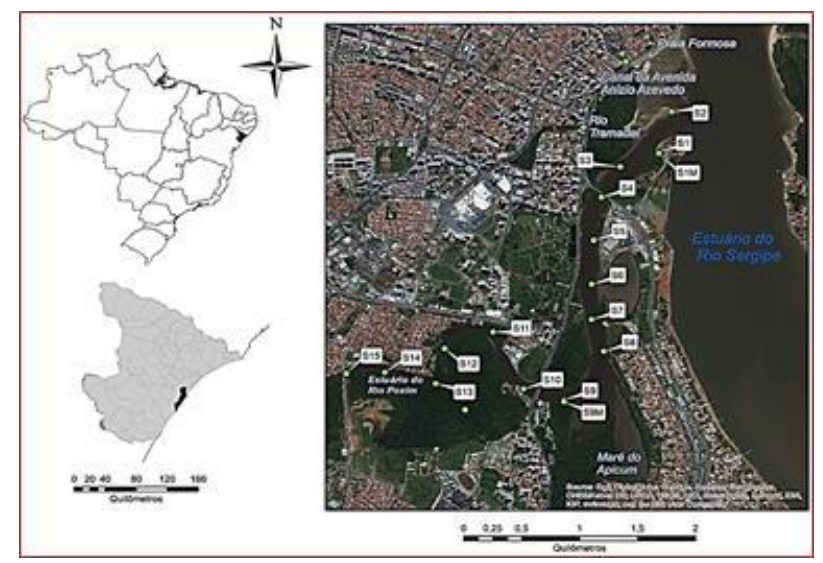


Os esteróis foram extraídos dos sedimentos (10 g, massa seca) por Extrator de Solvente Acelerado a partir do procedimento de Fang et al. (2006). Posteriormente, a fração de esteróis foi derivatizada em trimetilsilil éteres seguindo Frena et al. (2016). As análises foram realizadas no modo SIM em cromatógrafo em fase gasosa modelo Agilent 6890 GC acoplado a um espectrômetro de massas Agilent $5973 \mathrm{~N}$. Os 16 HPA prioritários foram extraídos dos sedimentos (5,0 g, massa seca) e ostras $(2,0 \mathrm{~g}$, massa seca), por ultrassom seguindo o procedimento de Barbosa et al. (2016).Para extrair os HPA das águas (2 L, filtrada) utilizou-se a extração líquido-líquido (50 mL de $n$ - hexano, $\mathrm{n}=3$ ), seguido de concentração e obtenção do extrato final $(1 \mathrm{~mL})$. As análises foram realizadas no modo MRM em cromatógrafo modelo GC-2010 plus, acoplado ao espectrômetro de massas triplo quadrupolo modelo GCMS-Tq8040 (GC-MS Shimadzu). Todos os procedimentos experimentais foram realizados por padronização interna, além de uso de padrões subrogados, curvas analíticas com coeficientes lineares acima de 0,99, limites de detecção e quantificação baseados na literatura (Souza et al., 2018), padrões certificados e solventes de alta pureza (HPLC).

\section{RESULTADOS E DISCUSSÃO}

Os cinco esteróis analisados foram detectados em todas as estações de coleta. A distribuiçãototal de esteróis foi dominada pelo $\beta$-sitosterol, sendo 37,2\% (março) e 70,8\% (agosto). Já o estigmasterol apresentou 9,3\% (março) e 8,9\% (agosto). Estes dois compostos são fitoesteróis relacionados à fonte de M0 advinda de plantas superiores, e associados à entrada de MO terrestre a partir do manguezal nas margens do sistema estuarino. Os níveis de colesterol variaram de 173 (S2d) a 24.885 (S1Mr) ng g-1, podendo originar-se de fontes biogênicas e/ou antropogênicas. Ele é atribuído à origem zooplanctônica e, no ambiente, é preferencialmente reduzido a colestanol (geralmente associado a ambientes não contaminados) que variou de 145 (S6d) a 4.659 (S15r) ng g-1 (Frena et al., 2019). Os níveis de coprostanol foram superiores a $100 \mathrm{ng} \mathrm{g}^{-1}$ (indicativo de poluição por esgoto) (Frena et al., 2019), com 58,8\% (março) e 93,7\% (agosto) das amostras em valores > $500 \mathrm{ng} \mathrm{g}^{-1}$. A estação S15, abaixo da ponte Gilberto Vila-Nova de Carvalho, foi a mais critica e apresentou valores $>20.000 \mathrm{ng} \mathrm{g}^{-1}$. Portanto, as amostras de sedimento mostraram evidências de severa contaminação fecal. Para confirmar, foram realizados cálculos de razões diagnósticas (Speranza et al., 2018). Para a razão $R 1$ [coprostanol/colesterol], 69,7\% das amostras em ambos os períodos apresentaram valores $>0,5$, considerado como poluição fecal. As razões $R 2$ [coprostanol/(colestanol+coprostanol)] > 0,7 e $R 3$ [coprostanol/colestanol] > 0,5, indicam contaminação por esgoto. Segundo a combinação destas duas razões (Figura 2), todas as amostras têm indicativo de fontes de esgoto, com exceção para a amostra S2r. Embora esta amostra tenha sido coletada em uma região com alta probabilidade de contaminação fecal, próxima ao canal da Avenida Anísio Azevedo (orla Praia Formosa), é provável que a constante mobilização de areiapor retroescavadeiras para reabertura do canal tenha modificado a real fonte de poluição.

Figura 2. Gráfico de dispersão das razões $R_{2}$ versus $R_{3}$ em sedimentos superficiais do sistema estuarino Sergipe-Poxim.

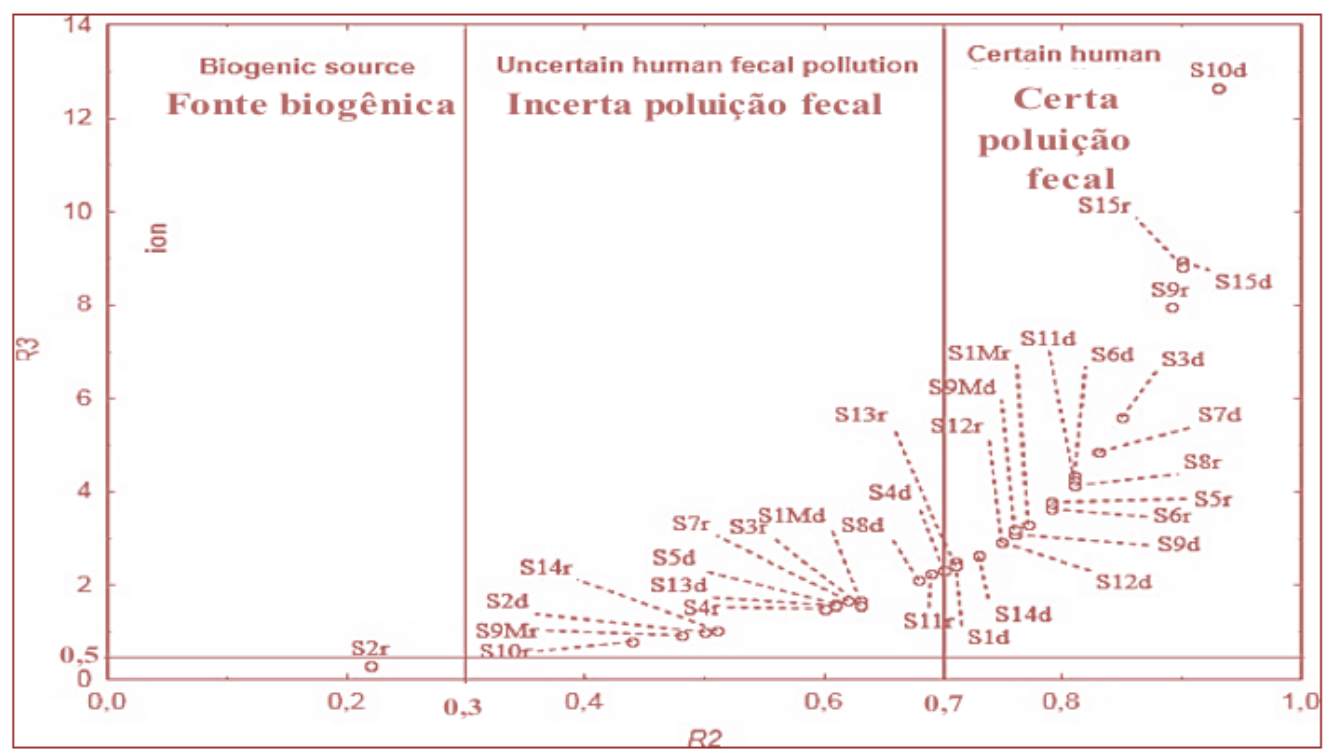


$\mathrm{R}_{2}=$ coprostanol $/($ coprostanol + colestanol $)$

Os HPA de menores massas moleculares (LMM, 2 a 3 anéis) foram dominantes nas águas em ambos os períodos (63,7\%, março; e 54,5\%, agosto), devido a maior solubilidade nesta matriz (Zhang et al., 2017). Os HPA de maiores massas moleculares (HMM, 4 a 6 anéis) foram dominantesnos sedimentos (92,7\%, março; e 90,5\%, agosto), por serem mais hidrofóbicos (Zhang et al., 2017).As ostras acumularam HPA de 2 a 4 anéis, por ser a fração mais solúvel nas águas filtradas pelos organismos. No geral, as amostras foram identificadas como micropoluídas (10 a $50 \mathrm{ng} \mathrm{L}^{-1}$, água) e de baixa contaminação $\left(<100 \mathrm{ng} \mathrm{g}^{-1}\right.$, sedimento e ostras) (Cao et al., 2010). Nas ostras foi quantificado o pireno, muito tóxico para bivalves (Xie et al., 2017), em ambos os períodos variando de 0,8 (04d) a 13,1 (04r) ng g-1. Portanto, mesmo em baixas concentrações, estes podem prejudicar a fauna do sistema. Para tanto, foram realizados cálculos do risco ecológico dos HPA presentes naágua e sedimento (Tabela 1). Assim, foram observados quocientes de risco (RQ) moderados (< 1) para o somatório individual dos HPA (RQSHPA(MPCs), em ambos os períodos. Portanto, esses resultados apontam para a necessidade de processos de correção para sanar quaisquer possibilidades de risco à biota. Já os valores dos quocientes de risco do $\sum$ HPA foram iguais a 0,000nas duas matrizes e nos dois períodos, sugerindo um baixo risco ecológico (Cao et al., 2010).

Tabela 1. Valores de Risco Ecológico dos HPA em água e sedimento superficiais coletados no sistema estuarino Sergipe-Poxim (RQ $\sum$ HPA(MPCs) = Quociente de risco do somatório individual dos HPA para as concentrações máximas permitidas, MPCs).

\begin{tabular}{|c|c|c|c|c|c|}
\hline \multirow{3}{*}{ Composto } & \multirow{3}{*}{ Sigla } & \multicolumn{2}{|c|}{ Água } & \multicolumn{2}{|c|}{ Sedimento } \\
\hline & & Março & Agosto & Março & Agosto \\
\hline & & $\mathbf{R} \mathbf{Q}_{\Sigma \mathrm{HPA}(\mathrm{MPCS})}$ & $\mathbf{R}_{\Sigma \mathrm{HPA(MPCs)}}$ & $\mathbf{R Q}_{\Sigma \mathrm{HPA}(\mathrm{MPCS})}$ & $\mathbf{R Q}_{\Sigma \mathrm{HPA}(\mathrm{MPCs})}$ \\
\hline Naftaleno & NAF & 0,008 & 0,003 & 0,004 & 0,021 \\
\hline Acenaftileno & ACENA & - & 0,002 & 0,007 & 0,003 \\
\hline Acenafteno & ACEN & - & - & 0,002 & - \\
\hline Fluoreno & FLU & 0,006 & 0,002 & 0,002 & 0,028 \\
\hline Fenantreno & FEN & 0,009 & 0,006 & 0,002 & 0,001 \\
\hline Antraceno & ANT & 0,021 & 0,023 & 0,004 & 0,003 \\
\hline Fluoranteno & FLT & 0,007 & 0,001 & - & - \\
\hline Pireno & PIR & 0,020 & 0,004 & 0,009 & 0,003 \\
\hline Benzo(a)antraceno & $\mathrm{BaA}$ & 0,257 & 0,185 & 0,006 & 0,002 \\
\hline Criseno & CRI & 0,005 & 0,003 & - & - \\
\hline Benzo(b)fluoranteno & $\mathrm{BbF}$ & 0,011 & 0,169 & 0,006 & 0,002 \\
\hline Benzo(k)fluoranteno & $\mathrm{BkF}$ & - & 0,028 & - & - \\
\hline Benzo(a)pireno & $\mathrm{BaP}$ & - & - & - & - \\
\hline Indeno(1,2,3-cd)pireno & IcdP & - & - & 0,001 & - \\
\hline Dibenzo(a,h)antraceno & DahA & - & - & - & - \\
\hline Benzo(g,h,i)perileno & BghiP & - & - & - & - \\
\hline$\Sigma \mathrm{HPA}$ & & 0,000 & 0,000 & 0,000 & 0,000 \\
\hline
\end{tabular}

Para identificar as fontes dos HPA no ambiente em estudo foram utilizadas as razões diagnósticas FLT/(FLT+PIR), $\sum$ LMM/ $\sum$ HMM, BbF/BkF, ANT/(ANT+FEN) e BaA/(BaA+CRI) (Souza et al., 2018). Sendo assim, a fonte prioritária foi a pirogênica para todas as matrizes, ou seja, provavelmente a combustão incompleta de biomassa e combustíveis fósseis são fontes potenciais destes compostos para o sistema. Observa-se em Aracaju uma alta frota veicular e alguns dos veículos, principalmente ônibus, circulam na cidade expelindo fumaça preta e rica em HPA. Além disso, é comum observar a queima de lixo nas margens do sistema estuarino Sergipe-Poxim. 
Portanto, medidas de fiscalização, prevenção e controle devem ser realizadas com urgência para reduzir os riscos de contaminação crônica do sistema estuarino Sergipe-Poxim.

\section{CONCLUSÕES}

1. A análise dos esteróis permitiu identificar fontes biogênicas e antropogênicas no sistema;

2. A qualidade sanitária do sistema estuarino apresentou-se inadequada;

3. As concentrações do coprostanol junto às razões diagnósticas, comprovaram a severacontaminação fecal nesta região;

4. Os HPA apresentaram-se em baixas concentrações em todas as matrizes;

5. Os riscos ecológicos (MPCs) demostraram-se moderados para os somatórios individuais dos HPA, enquanto que para o $\Sigma$ HPA mostraram-se de baixo risco;

6. Medidas corretivas devem ser realizadas para remediar possíveis efeitos tóxicos à biota da região;

7. A fonte prioritária dos HPA foi a pirogênica, indicativa da combustão incompleta de combustíveis fósseis e queimada de lixo nos arredores do sistema estuarino;

8. O sistema estuarino Sergipe-Poxim recebe intensa e negativa contribuição da cidade de Aracaju, necessitando de medidas corretivas urgentes.

\section{AGRADECIMENTOS}

Os autores agradecem à Fundação de Apoio à Pesquisa e à Inovação Tecnológica do Estado de Sergipe FAPITEC/SE (Edital FAPITEC/SE/CAPES n¹0/2015) e à Coordenação de Aperfeiçoamento de Pessoal de Nível Superior (CAPES) (PDSE - Edital n 19/2016 - Processo: 88881.133986/2016-01) pelo apoio financeiro, ao professor Dr. Yongsong Huang (Brown University) e ao CLQM (Centro de Laboratórios Químicos Multi-usuários) da Universidade Federal de Sergipe pelo apoio nas análises.

\section{REFERÊNCIAS}

[1] BARBOSA J.C.S. et al. Seasonal distribution of aliphatic hydrocarbons in the Vaza Barris EstuarineSystem, Sergipe, Brazil. Mar. Pollut. Bull.,104:343-346, 2016.

[2] CAO, Z., LIU, J., LUAN, Y., LI, Y., MA, M., XU, J., HAN, S. Distribution and ecosystem risk assessment of polycyclic aromatic hydrocarbons in the Luan River, China. Ecotox., 19:827-837, 2010.

[3] FANG, J. et al., Biomarker analysis of microbial diversity in sediments of a saline groundwater seepof Salt Basin, Nebraska. Org. Geochem., 37:912-931, 2006.

[4] FRENA, M., SANTOS, A.P.S., SOUZA, M.R.R., CARVALHO, S.S., MADUREIRA, L.A.S.,

[5] ALEXANDRE, M.R. Sterol biomarkers and fecal coliforms in a tropical estuary: Seasonal distributionand sources. Mar. Pollut. Bull., 139:111-116, 2019.

[6] FRENA, M., SOUZA, M.R.R., DAMASCENO, F.C., MADUREIRA, L.A.S., ALEXANDRE, M.R.

[7] Evaluation of anthropogenic contamination using sterol markers in a tropical estuarine system of Northeast Brazil. Mar. Pollut. Bull., 109:619-623, 2016.

[8] NILIN, J., SANTOS, A.A.O., NASCIMENTO M.K.S. Ecotoxicology assay for the evaluation ofenvironmental water quality in a tropical urban estuary. An. Acad. Bras. Ciênc., 91:1-10, 2019.

[9] RAMDINE, G., FICHET, D., LOUIS, M., LEMOINE, S. Polycyclic aromatic hydrocarbons (PAHs) in surface sediment and oysters (Crassostrea rhizophorae) from mangrove of Guadeloupe: levels, bioavailability, and effects. Ecoox. Environ. Saf., 79:80-89, 2012.

[10] SOUZA, M.R.R., et al. Concentration, distribution and source apportionment of polycyclic aromatic hydrocarbons (PAH) in Poxim River sediments, Brazil. Mar. Pollut. Bull., 127:478-483, 2018.

[11] SPERANZA, E.D., COLOMBO, M., SKORUPKA, C.N., COLOMBO, J.C. Early diagenetic alterations of sterol biomarkers during particle settling and burial in polluted and pristine areas of the Rio de la Plata Basin. Org. Geochem., 117:1-11, 2018.

[12] ZHANG A., ZHAO S., WANG L., YANG X., ZHAO Q., FAN J., YUAN X. Polycyclic aromatic hydrocarbons (PAHs) in seawater and sediments from the northern Liaodong Bay, China. Mar. Pollut. Bull., 113:592-599, 2017. 


\section{Capítulo 11}

Geotecnologias aplicadas ao mapeamento de áreas inundáveis frente a cenários de eventos extremos. Estudo de caso da microbacia do arroio São Lourenço, $R S$

Fernando Petersen Cardoso

Flávia Cristiane Farina

Tamiris da Silva Alves

Resumo: Os registros oficiais dos últimos anos demonstram um aumento no número e eventos extremos ocorridos no sul do Brasil, resultando em inundações periódicas com impactos sociais, econômicos, ambientais e de saúde pública. Neste sentido, o propósito deste trabalho é expor uma metodologia empregada para a modelagem de áreas sujeitas a inundação a fim de auxiliar a previsão e a tomada de decisões em situações de desastres. As análises são aplicadas ao município de São Lourenço do Sul, situado na metade sul do RS. A metodologia proposta está está organizada em duas fases principais, a primeira consiste na construção de um banco de dados em Sistemas de Informação Geográfica e no estudo e sistematização de variáveis relevantes para modelagem da área teste. A segunda fase se refere a aplicação de modelos hidrológico e hidrodinâmico para geração de cenários futuros através de "superfícies" de inundação, com o intuito de analisar os impactos que uma chuva intensa causará no município em questão. Para tal, foram utilizados os softwares ArcGIS, HEC-HMS e HEC-RAS. Os resultados abrangem as representações cartográficas e a análise da suscetibilidade à inundação para a área de interesse, de acordo com os parâmetros dos modelos implementados.

Palavras-chave: Modelagem hidrológica, Sistemas de Informação Geográfica, Inundações. 


\section{INTRODUÇÃO}

No Estado do Rio Grande do Sul (RS), localizado no sul do Brasil, as situações climáticas experimentadas nas últimas décadas têm sido responsáveis pelo aumento significativo do número de eventos extremos como vendavais, granizos, deslizamentos e inundações. Os registros oficiais dos últimos anos mostram um acentuado crescimento destes eventos nos municípios costeiros do Estado e, consequentemente, dos prejuízos sociais, econômicos e ambientais (Defesa Civil RS, 2014).

Em específico, o município de São Lourenço do Sul, localizado na zona costeira, sofreu um episódio de precipitação concentrada entre os dias 09 e 10 de março de 2011 que gerou uma inundação brusca, cobrindo mais da metade de sua área, com água a 2,7 metros de altura, em média. Cerca de 20.000 pessoas foram afetadas, 300 famílias estiveram isoladas e cerca de 500 pessoas ficaram expostas ao mau tempo aguardando o resgate. Pontes foram submersas ou destruídas, isolando o extremo sul do Estado (Sausen et al., 2012).

A origem destas situações tem sido atribuída aos recorrentes eventos climáticos extremos, porém, os fatores antrópicos, como os padrões de cobertura e uso do solo, a alta impermeabilização das áreas urbanas, o desrespeito à legislação do Código Florestal Brasileiro no que tange à ocupação de Áreas de Preservação Permanente no meio urbano e rural são fatores preponderantes na ampliação dos danos causados pelos eventos hidrometeorológicos. Por outro lado, o enfrentamento de situações de desastres no Brasil tem evoluído para além de ações pós-evento (resgate, assistência de vítimas e reconstrução), no sentido da gestão do risco e do gerenciamento de desastres. Essa nova sistemática é descrita na Política Nacional de Proteção e Defesa Civil (PNDC, Lei 12.608 de 10/04/2012), e prevê as seguintes ações: prevenção, mitigação, preparação, resposta e recuperação (Brasil, 2012; CEPED, 2016). Como ações de prevenção, o PNPDC ressalta a necessidade de identificar e mapear áreas de risco e realizar estudos de identificação de ameaças, suscetibilidad es e vulnerabilidades.

A suscetibilidade é a maior ou menor predisposição de ocorrência de um determinando evento extremo em uma área específica e, no caso das inundações, resulta de um conjunto de fatores que condicionam a sua ocorrência, como por exemplo, cobertura e uso da terra, tipos de solo e declividade (Bressani and Costa, 2013, CEPED, 2016). Atualmente, diversos são os métodos empregados para geração de modelos de suscetibilidade a inundação, entre os quais destacam-se aqueles que utilizam simulação hidrológica e hidráulica integrada aos Sistemas de Informação Geográfica (GIS) (Tunas e Maadji, 2018; Cabral, 2016; Decina e Brandão, 2016; Correia et al, 2015; Suriya and Mudgal, 2012; Knebl et al, 2005;). De maneira geral, tais estudos definem a estratégia metodológica considerando os parâmetros físicos da região de estudo, a disponibilidade de dados e a opção por um conjunto de técnicas de modelagem específicas dentro do instrumental disponível.

Diante do exposto, o propósito deste artigo é expor a modelagem desenvolvida para o mapeamento de áreas suscetíveis à inundação, baseada na integração entre softwares de modelagem hidrológica e hidrodinâmica com Sistemas de Informação Geográfica. O modelo é aplicado na microbacia do Rio São Lourenço, na qual está inserida a maior parte da área urbana do município de São Lourenço do Sul, no Estado do Rio Grande do Sul (Figura 1). Trata-se de uma microbacia com área de cerca de $197 \mathrm{~km}^{2}$, com altitudes que variam entre zero e 240 metros. 
Figura 1 - Localização e delimitação da microbacia do Rio São Lourenço do Sul, RS.

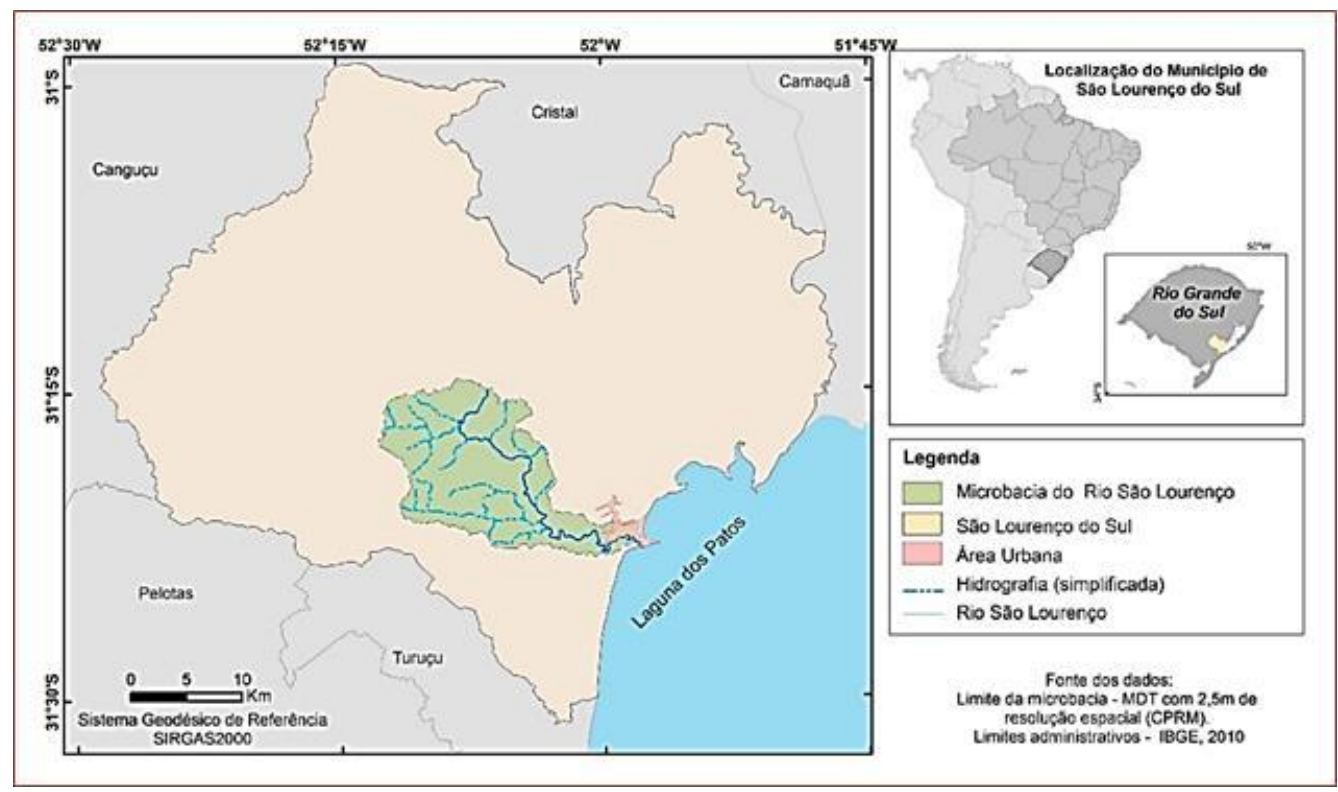

Fonte: Elaborado pelos autores

\section{METODOLOGIA}

O arranjo metodológico deste trabalho está organizado em duas fases principais: elaboração de um banco de dados em ambiente SIG com as variáveis pertinentes ao estudo e; modelagem hidrológica e hidrodinâmica, nos softwares HEC-HMS, HEC-RAS, integrados ao SIG ArcGIS, por meio da extensão HECGeoRAS. A seguir, são descritas em detalhe cada uma dessas etapas.

\subsection{ELABORAÇÃO DO BANCO DE DADOS EM SIG}

A primeira etapa da metodologia se fundamenta na revisão, na organização e no armazenamento de dados geográficos disponíveis para o município de São Lourenço do Sul, provenientes de fontes públicas disponibilizadas por órgãos oficiais como Instituto Brasileiro de Geografia e Estatística (IBGE), Companhia de Pesquisa de Recursos Minerais (CPRM), Agência Nacional das Águas (ANA), Fundação Estadual de Proteção Ambiental Henrique Luiz Roessler (FEPAM-RS), United States Geological Survey (USGS), entre outros. Este banco de dados teve por objetivo caracterizar o município, delimitar a microbacia de interesse e obter os parâmetros físicos necessários às etapas seguintes. 0 banco foi elaborado no SIG ArcGIS e é composto por imagens do satélite RapideEye, mapas temáticos de geologia, geomorfologia, modelo digital de elevação (MDE), modelo digital do terreno (MDT) declividade, pedologia, além das tabelas associadas aos setores censitários do IBGE. Outras informações foram derivadas a partir dos dados originais, como o mapa de cobertura e uso da terra, declividade e hidrografia.

A microbacia do Rio São Lourenço (Figura 1) foi delimitada por meio da extensão ArcHydro do ArcGIS, utilizando-se como dados de entrada o MDE, com 2,5 metros de resolução espacial, disponibilizado online pela CPRM e, o layer da hidrografia, de mesma fonte. A hidrografia foi previamente ajustada, aplicando-se correções espaciais com base nas imagens do satélite RapidEye.

\subsection{MODELAGEM HIDROLÓGICA E HIDRODINÂMICA}

A segunda etapa da metodologia consiste na modelagem hidrológica e hidrodinâmica, nos softwares HEC$H M S$, HEC-RAS, integrados ao ArcGIS, por meio da extensão HEC-GeoRAS.A Para tal, a microbacia do Rio São Lourenço foi subdividida em quatro sub-bacias, a fim de se obter resultados mais precisos devido às limitações quanto à extensão de área imposta por alguns dos métodos a serem aplicados. Em função disso, criou-se o modelo topológico do conjunto das sub-bacias de interesse, para a entrada e saída dos dados e posterior cálculo do transporte da vazão. 
Inicialmente, empregou-se o modelo hidrológico desenvolvido pelo Soil Conservation Service (SCS), o qual estima a precipitação efetiva e a distribuição do escoamento superficial (Geetha et al, 2008). Esse modelo utiliza como principal parâmetro o número da curva de escoamento superficial, ou Curve Number (CN). 0 valor de CN é obtido a partir da relação entre os tipos de solo, de cobertura e uso da terra e das condições de umidade antecedentes (grupos hidrológicos), presentes na região de interesse. Tucci (1995) apresenta uma compilação da classificação dos solos quanto aos grupos hidrológicos (A, B, C, D) e suas características, bem como os valores de CN para cobertura e uso da terra em bacias rurais. Neste sentido, baseando-se, no trabalho de Sartori et al (2005), atribuiu-se os seguintes grupos hidrológicos aos tipos de solo da área de estudo: B (argissolos vermelho-amarelo), C (neossolo flúvico) e, D (planossolo háplico). Os grupos hidrológicos foram então cruzados com as cinco classes de cobertura e uso da terra (campo e pastagem, mata, solo exposto, cultivo agrícola e área urbana), resultando nos valores de CN apresentados na Tabela 1.

Tabela 1 - Número de curva CN do SCS

\begin{tabular}{|l|c|c|c|}
\hline \multicolumn{1}{|c}{ Cobertura e uso da terra } & B & C & D \\
\hline Campo ou pastagem & 58 & 71 & 78 \\
\hline $\begin{array}{l}\text { Mata e vegetação } \\
\text { arbustiva/arbórea }\end{array}$ & 60 & 70 & 76 \\
\hline Solo exposto & 80 & 87 & 90 \\
\hline Cultivo agrícola (arroz) & 75 & 83 & 87 \\
\hline Área urbana & 92 & 94 & 95 \\
\hline
\end{tabular}

Fonte: Elaborado pelos autores

Para a geração do valor da retenção potencial máxima utilizou-se a equação que relaciona este parâmetro com o CN (S = 25.400/CN - 254). Dessa forma, primeiro se calculou o tempo de concentração das subbacias, utilizando a equação de Kirpich (NRCS, 2010), para em seguida selecionar um tempo de duração de chuva adequado (chuva de projeto), visando à obtenção de cálculos mais precisos. Posteriormente, os seguintes parâmetros físicos foram extraídos das sub-bacias: comprimento do talvegue, diferença de cotas no canal principal, CN médio, área, tempo de concentração e "lag time”, conforme exposto na Tabela 2.

Tabela 2 - Parâmetros físicos extraídos das sub-bacias do Rio São Lourenço

\begin{tabular}{|c|c|c|c|c|c|c|}
\hline $\begin{array}{l}\text { Sub- } \\
\text { bacia }\end{array}$ & $\begin{array}{l}\text { Comprimento } \\
\text { talvegue }(\mathrm{km})\end{array}$ & $\begin{array}{l}\text { Diferença de cotas } \\
\text { (m) }\end{array}$ & $\begin{array}{c}\mathrm{CN} \\
\text { médio }\end{array}$ & $\begin{array}{c}\text { Área } \\
\left(\mathbf{k m}^{2}\right)\end{array}$ & $\begin{array}{c}\text { Tempo concentração } \\
\text { (min) }\end{array}$ & $\begin{array}{l}\text { Lag } \\
\text { time }\end{array}$ \\
\hline 1 & 16,60 & 12 & 83,30 & 28,86 & 561,85 & 337,11 \\
\hline 2 & 12,80 & 87 & 69,66 & 55,07 & 194,08 & 116,45 \\
\hline 3 & 12,70 & 76 & 72,47 & 38,59 & 202,61 & 121,56 \\
\hline 4 & 12,50 & 98 & 61,56 & 75,25 & 180,38 & 108,23 \\
\hline
\end{tabular}

Fonte: elaborado pelos autores

A determinação da vazão (propagação das cheias) apoiou-se no método de Muskingum-Cunge, que necessita de dados de entrada de vazão, de topografia do terreno e dos coeficientes de rugosidade Manning. Os coeficientes Manning foram obtidos em Chow (2009), atribuindo-se os valores 0,035 no leito do canal e 0,045 na planície de inundação.

A partir desses dados, procedeu-se o cálculo e a simulação das vazões de pico de uma chuva de projeto para diferentes períodos de retorno (RP), expressos em anos. As vazões podem ser calculadas em qualquer ponto das sub-bacias, porém, optou-se por aplicar a modelagem em um ponto do Rio São Lourenço localizado na entrada da área urbana, que se estende até a foz na Laguna dos Patos. Uma chuva de projeto é um evento chuvoso idealizado, ao qual está associado um RP, ou uma probabilidade a qual esse evento possa ser igualado ou superado em um ano qualquer. O RP é uma variável utilizada em 
hidrologia para avaliar os eventos extremos, como é o caso de chuvas intensas, e relaciona a altura máxima de precipitação, a qual determina as características específicas de uma inundação, como sua duração, altura, área abrangida e velocidade (Collischonn e Tassi, 2008).

Para estimar a vazão máxima, a duração da chuva de projeto deve ser definida de forma que toda a bacia contribua, ao mesmo tempo, para o escoamento que alcança o ponto selecionado. Portanto, deve-se considerar que o tempo de duração da chuva seja igual ou superior ao maior tempo de concentração das sub-bacias delimitadas.

A chuva de projeto é geralmente obtida por meio das curvas que relacionam intensidade média, duração e frequência (IDF curves) (Paola et al, 2014). As curvas IDF são geradas a partir da análise estatística das chuvas mais intensas observadas em pluviógrafos, ou de dados de pluviômetros desagregados para durações menores que um dia. Porém, as curvas IDF para o município de São Lourenço do Sul, calculadas para os tempos de retorno 2, 5, 10,15, 20, 25, 50 e 100 anos, foram geradas utilizando-se os coeficientes da Equação IDF da região de interesse, propostos por Sampaio (2011).

Para a distribuição temporal da chuva, foi adotado um Specified Hyetograph, no qual as chuvas foram espacializadas no tempo, em intervalos de 10 minutos, na unidade de milímetros incrementais, e suas intensidades distribuídas conforme as distribuições de Huff (Huff, 1990). Devido o maior "lag time” obtido ser 337,11 minutos, ou seja, menor do que sei horas, optou-se pela seleção do primeiro quartil de distribuição de Huff para espacializar a chuva. Entre os RP definidos, foram selecionados 10, 25 e 50 anos, sendo este último o evento mais extremo.

Nesta etapa, deu-se entrada no HEC-HMS dos dados apresentados na Tabela 2 e da chuva de projeto. Como resultado do modelo hidrológico, foram obtidas as seguintes vazões máximas para o ponto selecionado na microbacia do Rio São Lourenço, com seus respectivos RP: RP 10 anos = 206m³/s; RP 25 anos = $318,4 \mathrm{~m}^{3} / \mathrm{s} ; \operatorname{RP} 50$ anos $=345,6 \mathrm{~m}^{3} / \mathrm{s}$.

Para a simulação hidráulica da inundação na áera de estudo, passou-se ao programa HEC-RAS, que utiliza como dados de entrada os Manning' Roughness Coefficients, as vazões máximas obtidas no modelo hidrológico, e parâmetros hidráulicos do rio (geometria: rede de drenagem, seções tranversais, limites da calha, planície de inundação). Estes parâmetros foram gerados previamente no ArcGIS, com a extensão HEC-GeoRAS, a partir da vetorização sobre imagens do satélite RapidEye, apoiada no MDT e no detalhe das imagens do software GoogleEarth. Em algumas das seções tranversais delimitadas haviam dados de batimetria disponíveis, portanto, tais seções foram editadas manualmente, de modo a aprimorar o dado.

Concluída esta etapa, foram inseridos no HEC-RAS a geometria do canal, os coeficientes de Manning e os dados de vazão obtidos pelo modelo hidrológico. Desse modo, a modelagem hidrodinâmica é implementada para os tempos de retorno 10, 25 e 50 anos, resultando na simulação de "superfícies" de inundação. Essas "superfícies" representam a distribuição espacial da inundação, para a chuvas de projeto com os RP especificados.

\section{RESULTADOS}

De modo a melhor apresentar os dados e posteriormente processá-los e integrá-los a outras informações, as superfícies inundáveis produzidas no HEC-RAS foram exportadas para um formato raster compatível com o ArcGIS. As áreas de inundação simuladas representam o limite (altura) que a inundação atinge nos RP de 10, 25 e 50 anos, ou seja, os impactos que uma chuva intensa causará na área em questão. 0 alcance dessas superfícies está relacionado às cotas do terreno obtidas no MDT, portanto, para fins de melhor entendimento, converteu-se o alcance da água para uma variação de tonalidades.

A Figura 2 apresenta a espacialização da inundação simulada, sobre uma imagem do GoogleEarth, com TR de 50 anos. As tonalidades de azul mais escuras representam as maiores cotas de inundação, consequentemente, as áreas primeiramente atingidas, ou seja, de maior suscetibilidade ao fenômeno. A mancha para esse caso mais extremo (50 anos) resultou em uma área inundável de 3,84km² e; para 25 anos, 1,64 km² e; para 10 anos, 1,33 $\mathrm{km}^{2}$.

De modo geral, a intersecção da área suscetível à inundação com o mapa de cobertura e uso da terra, revelou que as áreas ao sul do Rio são compostas, em sua maior parte, pelo cultivo do arroz. Porém, a situação mais preocupante se refere às áreas localizadas ao norte, que concentram o uso urbano e, consequentemente, são mais vulneráveis devido aos aspectos demográficos e econômicos. 0 aprofundamento do estudo se dará com a caracterização das áreas suscetíveis por meio da sua interseção 
com os dos dados estatísticos sobre os aspectos demográficos, sociais e econômicos, disponibilizados pelo IBGE. Desse modo, poderá ser mapeada também a vulnerabilidade das áreas sujeitas a inundações.

Figura 1 - Suscetibilidade à inundação simulada para uma chuva de projeto com período de retorno de 10 e 50 anos.

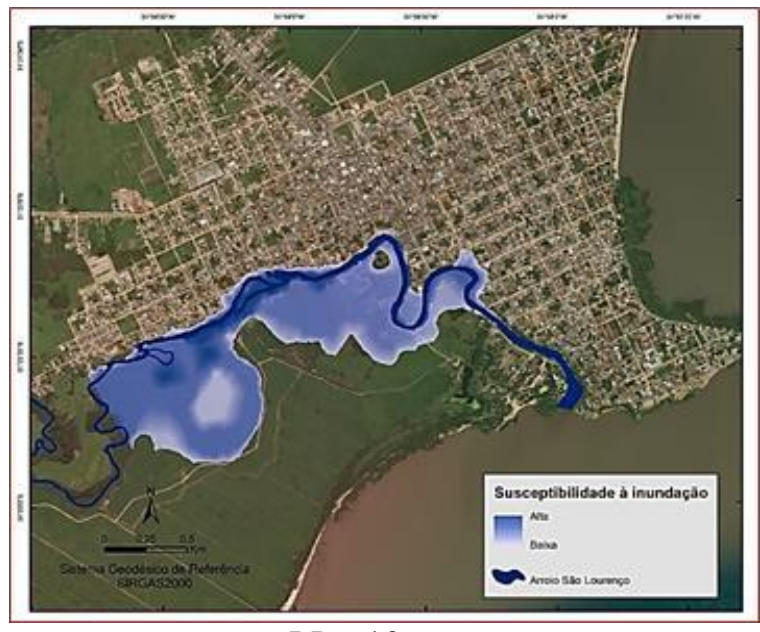

$\mathrm{RP}=10$ anos

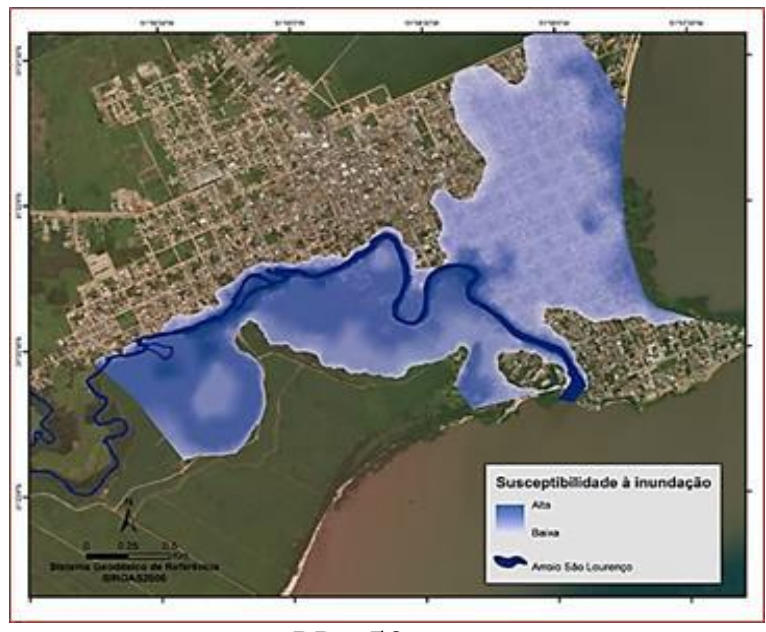

$\mathrm{RP}=50$ anos

Fonte: Elaborado pelos autores

\section{CONCLUSÕES}

De maneira geral, pode-se concluir que a modelagem ideal de áreas sujeitas à inundação é menos complexa quando estão disponíveis dados hidrológicos de eventos extremos já ocorridos, tais como a precipitação pluviométrica, cotas e tempo do alcance da inundação, entre outros. Cabe salientar também que os produtos cartográficos disponíveis em fontes públicas são produzidos em diversas escalas, geralmente pequenas, como é o caso do mapa de solos, dificultando a integração dos mesmos com produtos de maior escala, por vezes disponíveis para áreas de estudo de extensão reduzida.

Por outro lado, os resultados obtidos permitem concluir que a metodologia proposta é adequada para aplicação em qualquer outra microbacia para a qual não se disponha de dados de vazão. A integração entre os softwares de modelagem hidrológica/hidrodinâmica, por meio da extensão HEC-GeoRAS, com o SIG ArcGIS se mostrou de grande valia, permitindo que os dados essencialmente numéricos dos primeiros pudessem ser espacializados e, posteriormente avaliados com outras variáveis de interesse.

A partir das análises dos parâmetros gerados e das superfícies de inundação simuladas, concluiu-se que o Rio São Lourenço, no ponto considerado, não suporta escoar as precipitações intensas associadas aos tempos de retorno de 10, 25 e 50 anos. Portanto, espera-se que o modelo elaborado, os dados produzidos e informações a serem ainda incorporadas ao estudo, possam servir como subsídios para a tomada de medidas preventivas, no caso de eventos extremos.

\section{AGRADECIMENTO}

Os autores agradecem ao Conselho Nacional de Desenvolvimento Científico e Tecnológico (CNPq) pelo financiamento do projeto, à FAPERGS e à UFRGS pelas bolsas de Iniciação Científica e de Extensão. 


\section{REFERÊNCIAS}

[1] BRASIL. Lei № 12.608, de 10 de abril de 2012. Institui a Política Nacional de Proteção e Defesa Civil PNPDEC; dispõe sobre o Sistema Nacional de Proteção e Defesa Civil -SINPDEC e o Conselho Nacional de Proteção e Defesa Civil - CONPDEC; e dá outras providências. Brasília, 2012

[2] BRESSANI L.A.; COSTA, E. A. Mapeamento Geotécnico - Suscetibilidade, Perigo, Vulnerabilidade, Risco Instalado e Risco. Proceedings $14^{\circ}$ Congresso Brasileiro de Geologia de Engenharia Ambiental Rio de Janeiro, 2013. Rio de Janeiro, 2013, 10p.

[3] CABRAL, S. L. et al (2016). Integração do SIG, HEC/HMS e HEC/RAS no mapeamento de área de inundação urbana: aplicação à bacia do Rio Granjeiro-CE. Revista Geociências, São Paulo, 35 (1), pp .90-101

[4] CHOW, V. T. Open-channel hydraulics. Caldwel, Blackbur, 2009.

[5] COLLISCHONN, V.; TASSI, R. Introduzindo Hidrologia. Porto Alegre, UFRGS, 2009.

[6] CORREIA, E.F.G.; RIBEIRO, G.P.; BAPTISTA, A. C. Modelagem hidrológica da Bacia Hidrográgica do Rio Bengalas, Nova Friburgo, RJ, utilizando o potencial de geotecnologias na definição de áreas de risco à inundação. Revista Brasileira de Cartografia, Rio de Janeiro, 67 (6), p.p.1183-1202, dez. 2015.

[7] CEPED. Centro Universitário de Estudos e Pesquisas sobre Desastres da Universidade Federal do Rio Grande do Sul. Capacitação em Gestão de Riscos. 2ª . Ed. Porto Alegre: UFRGS, 2016.

[8] DECINA, T. G. T.; BRANDÃO, J. L. B.. Análise de desempenho de medidas estruturais e não estruturais de controle de inundações em uma bacia urbana. Engenharia Sanitaria e Ambiental, [s.l.], v. 21, n. 1, p.207-217, mar. 2016. FapUNIFESP (SciELO).

[9] GEETHA, K., MISHRA, S. K., ELDHO, T. I., RASTOGI, A. K., \& PANDEY, R. P.: SCS-CN-based continuous simulation model for hydrologic forecasting, Water Resource Management Journal, 22(2), 165-190, 2008.

[10] HUFF, F. A. Time distributions of heavy rainstorms in Illinois. Illinois State Water Survey, Circular 173. Champaign, Illinois, 1990.

[11] KNEBL, M.r. et al. REGIONAL SCALE FLOOD MODELING USING NEXRAD RAINFALL, GIS, AND HEC-HMS/RAS a case study for the San Antonio River Basin Summer 2002 storm event. Journal Of Environmental Management, v. 75, n. 4, p.325-336, jun. 2005.

[12] NRCS. Natural Resources Conservation Service. Time of concentration. National Engineering Handbook. Chapter 15, 2010.

[13] PAOLA, F. D.; GIGUNI, M.; TOPA, M. E.; BUCCHIGNANI, E. Intensity-Duration-Frequency (IDF) rainfall curves, for data series and climate projection in African cities. Springer Plus. v.3, n 133, 2010.

[14] SAMPAIO, M. V. Espacialização dos coeficientes das equações de chuvas intensas em Bacias Hidrográficas do Rio Grande do Sul. 2011. 146 f. Tese (Doutorado), Universidade Federal de Santa Maria, Santa Maria, 2011.

[15] SARTORI, A.; LOMBARDI NETO, F.; GENOVEZ, A. M. Classificação hidrológica de solos brasileiros para a estimativa da chuva excedente com o método do serviço de conservação do solo dos Estados Unidos. Parte 1: Classificação. Revista Brasileira de Recursos Hídricos, v.10, n.4, p.05-18, 2005.

[16] SAUSEN, T. M.; LACRUZ, M. S. P.; PEREIRA, R. S. Evento de inundação brusca ocorrido em São Lourenço do Sul, RS, em 10 de março de 2011. In: Congresso Brasileiro sobre Desastres Naturais. Rio Claro: UNESP. p. 1-12. 2012.

[17] SURIYA, S.; MUDGAL, B.v.. IMPACT OF URBANIZATION ON FLOODING: The Thirusoolam sub watershed - A case study. Journal Of Hydrology, v. 412-413, p.210-219, jan. 2012.

[18] TUCCI, C.E.M. Inundações Urbanas. In: Tucci, C.E.M.; Porto, R.L.L.; Barros, M.T. Drenagem Urbana. Porto Alegre: Ed. Universidade/UFRGS/ABRH, 1995, V.5, p.15-36.

[19] TUNAS, I.G.\& MAADJI, R. The Use of GIS and Hydrodynamic Model for Performance Evaluation of Flood Control Structure. International Journal on Advanced Science Engineering Information Technology. v.8, n.6, p. 24132420, 2018. 


\section{Capítulo 12}

Evapotranspiração de referência e balanço hídrico no município de Itabaiana/Sergipe

\section{Nivia Raquel Oliveira Alencar}

Eveline Leal da Silva

Michelle Pereira da Costa da Silva

Ramiro Ferreira dos Santos Farias

Inajá Francisco de Sousa

Resumo: A evapotranspiração de referência é um importante componente no gerenciamento de recursos hídricos. 0 presente estudo objetivou fazer uma análise comparativa entre os métodos de estimativa de Evapotranspiração Potencial e realizar um esboço do Balanço Hídrico do município de Itabaiana/SE. Sendo realizada usando como base a equação empírica proposta por Penman-Monteith, equação parametrizada no boletim FAO 56. Para tal, foram utilizados dados do Instituto Nacional de Meteorologia (INMET) coletados e analisados no recorte temporal de julho de 2017 e julho de 2018 observando a sazonalidade nos períodos secos e chuvosos, como também a variação do armazenamento da água do solo pela estimativa da evapotranspiração real e eficiência do excedente. Após a análise dos dados, foi constatado que as correlações entre os métodos propostos por Penman-Monteith e Hargreaves-Samani e PenmanMonteith e Priestley-Taylor apresentaram uma correlação mediana, com um $\mathrm{r}^{2}$ de 0,62 e $\mathrm{r}^{2}$ de 0,60 para cada um respectivamente. Constituindo-se métodos de fácil utilização, podendo ser adotados em eventuais estudos no município.

Palavras-Chave: Precipitações; CAD; deficiência hídrica. 


\section{INTRODUÇÃO}

Para o planejamento e operação eficiente dos perímetros de irrigação faz-se necessário o conhecimento preciso da intensidade do consumo de água pelas culturas e das características de sua retenção pelo solo, levando em consideração as condições meteorológicas locais dominantes. Com o avanço das tecnologias de irrigação, têm sido desenvolvidos vários estudos com a finalidade de fornecer subsídios que permitam estimar as reais necessidades hídricas das culturas em função de parâmetros ambientais e do solo. Tal conhecimento pode condicionar o manejo de água no sistema solo-planta-atmosfera de maneira racionalizada visando otimizar a produtividade.

O uso racional dos recursos hídricos preconiza a preservação e a otimização do uso da água. Segundo informações da FAO, a irrigação é uma das atividades que mais demanda água, atingindo cerca de $70 \%$ do volume utilizado no mundo. Como o consumo de água pelas plantas varia de espécie, estádio fenológico e o clima, deve-se determinar a quantidade exata de água a ser aplicada, a fim de se reduzir em perdas na produção, tanto por excesso quanto por déficit.

A evapotranspiração é uma das formas pela qual a água durante o ciclo hidrológico retorna a atmosfera na forma de vapor. Esse processo envolve a evaporação de lâminas d'água principalmente dos oceanos, mares, rios e lagos, dos solos, da água retida pelo dossel de plantas e a transpiração das mesmas simultaneamente (ALLEN et al., 2006).

A evapotranspiração (ET) é considerada um processo simultâneo de transferência de água para a atmosfera por evaporação da água existente no solo e através da transpiração das plantas. Thornthwaite (1948) introduziu na literatura especializada o termo evapotranspiração potencial (ETp), definindo-a como sendo a quantidade máxima de água utilizada por uma extensa área vegetada, em crescimento ativo, sob condições ótimas de umidade de solo.

As observações meteorológicas de superfície são de suma importância na determinação da evapotranspiração (ET). Neste processo de transferência de vapor d'água, os elementos climáticos controlam a demanda hídrica da atmosfera, atuando, no contínuo solo-planta-atmosfera, como dreno. A automação dessas medições, em tempo real, facilita a obtenção da Evapotranspiração de referência e consequentemente, permite estabelecer estratégias de manejo de irrigação, determinando o volume de água necessário aos sistemas agrícolas e dimensionar sistemas de distribuição e de armazenamento de água (FARIA, 1998).

O controle da irrigação tem por finalidade manter o conteúdo de água no solo em nível ótimo, de forma que a condutividade hidráulica na zona radicular não atinja um valor crítico, abaixo do qual o solo passa a restringir a evapotranspiração da cultura. Isto poderá ocorrer principalmente em períodos de alta demanda evaporativa da atmosfera, ocorrendo redução na abertura estomática ou mesmo o fechamento desta, em razão do déficit hídrico gerado nas células adjacentes à câmara estomática nas folhas.

A mensuração da evapotranspiração de referência $\left(\mathrm{ET}_{0}\right)$ é de fundamental Importância para o estudo do balanço hídrico de um sistema, no planejamento e manejo da irrigação e no gerenciamento e uso racional dos recursos hídricos (LACERDA; TURCO, 2015).

A estimativa da perda de água por meio dos processos de evaporação ou evapotranspiração, segundo Martinez et al. (2006) tem relevância primária para o monitoramento, pesquisa e o manejo de recursos hídricos, tanto em escala local (propriedade agrícola) quanto em escala regional.

Ainda que exista uma variedade de modelos de estimativa da $\mathrm{ET}_{0}$, as condições do clima de cada região interferem na eficácia do método, já que os mesmos foram concebidos em condições climáticas e agronômicas diferentes das que eventualmente serão utilizadas (SILVA et al., 2005; SOUSA et al., 2010). 0 método proposto por Penman-Monteith para determinação da $E_{0}$ é usado como modelo padrão por apresentar melhor desempenho em climas variados (ALLEN et al., 1998).

A evapotranspiração de referência, segundo Bernardo et al. (2006), pode ser estimada por métodos diretos e indiretos. 0 tanque classe " $\mathrm{A}$ " é um dos métodos indiretos de uso generalizado inclusive no Brasil, em virtude do seu fácil manejo e baixo custo de implantação. No entanto, esse método requer a determinação de um coeficiente denominado coeficiente do tanque (Kp), que varia de acordo com o local e as condições climáticas (ALLEN et al., 1998).

Doorenbos e Pruitt (1977) definiram a evapotranspiração de referência (ET0) como sendo evapotranspiração que ocorre em uma extensa superfície de grama, com porte de 8 a $15 \mathrm{~cm}$, em crescimento ativo, cobrindo o solo e sem restrições de água. De acordo com Burman et al. (1993) ela pode ser estimada a partir de medidas diretas (lisímetros e o balanço de água no solo) ou de informações 
climáticas (modelos teóricos e empíricos, evaporímetros). A escolha do método a ser utilizado depende de três aspectos básicos: da precisão necessária, da adequação do método às condições locais e da disponibilidade de dados meteorológicos. Quanto maior a complexidade do método, mais precisa ele se torna (BERGAMASCHI et al., 1999).

A agricultura irrigada é uma das principais atividades econômicas da área de estudo, característica que justifica a relevância de estudar as condições climatológicas, uma vez que a evapotranspiração é um indicador base para a irrigação.

Diante desse contexto, o presente trabalho tem como objetivo apresentar dados climatológicos sobre a Evapotranspiração real, Potencial, uma análise comparativa da correlação dos principais métodos de estimativa de ETo (Priestley-Taylor e Hargreaves-Samani) tendo como base o método de PenmanMonteith, bem como um esboço do Balanço Hídrico do município de Itabaiana-SE.

\section{MATERIAIS E MÉTODO}

O município de Itabaiana está localizado no estado de Sergipe, conforme Figura 1. Situa-se no agreste sergipano, que consiste numa faixa de transição climática entre o litoral e o sertão. 0 município possui uma extensão territorial de 336,9 $\mathrm{km}^{2}$, ocupando apenas 1,53\% do território sergipano. Sua sede municipal distancia-se da capital do Estado, Aracaju, em 56 km (CARVALHO; COSTA, 2010). Em termos demográficos, segundo dados do Instituto Brasileiro de Geografia e Estatística (IBGE) na última contagem populacional (2015), a população de Itabaiana é de 93.572 habitantes. Essa região, por localizar-se no Agreste sergipano em área de transição entre a Zona da Mata e o Sertão, possui o clima de acordo com a classificação de Koppen, do tipo As, clima quente, com temperatura média anual de $24,5 \stackrel{\circ}{\circ}$, evapotranspiração anual de $1.850 \mathrm{~mm}$ anual, umidade relativa média de 60\% (SILVA, 2004). 0 regime pluviométrico na região possui uma distribuição espacial e temporal irregular, que é uma característica da região Nordeste do Brasil. Em função disso, a sua sazonalidade de precipitação concentra quase todo o seu volume durante os cinco meses no período de inverno (SILVA, 2004). A precipitação pluviométrica média anual é de 896,5 mm, sendo que o período chuvoso ocorre entre maio e julho (DINIZ et al., 2014).

A análise temporal realizada nesse estudo corresponde ao período de 06/07/2017 a 06/07/2018, os dados utilizados nesta pesquisa foram extraídos da estação meteorológica automática do Instituto Nacional de Meteorologia (INMET). Após a coleta, os dados foram organizados e tabulados no programa computacional Microsoft Office Excel 2016 e aplicados às fórmulas de cada modelo adotado para análise.

Figura 1. Localização do município de Itabaiana/SE.

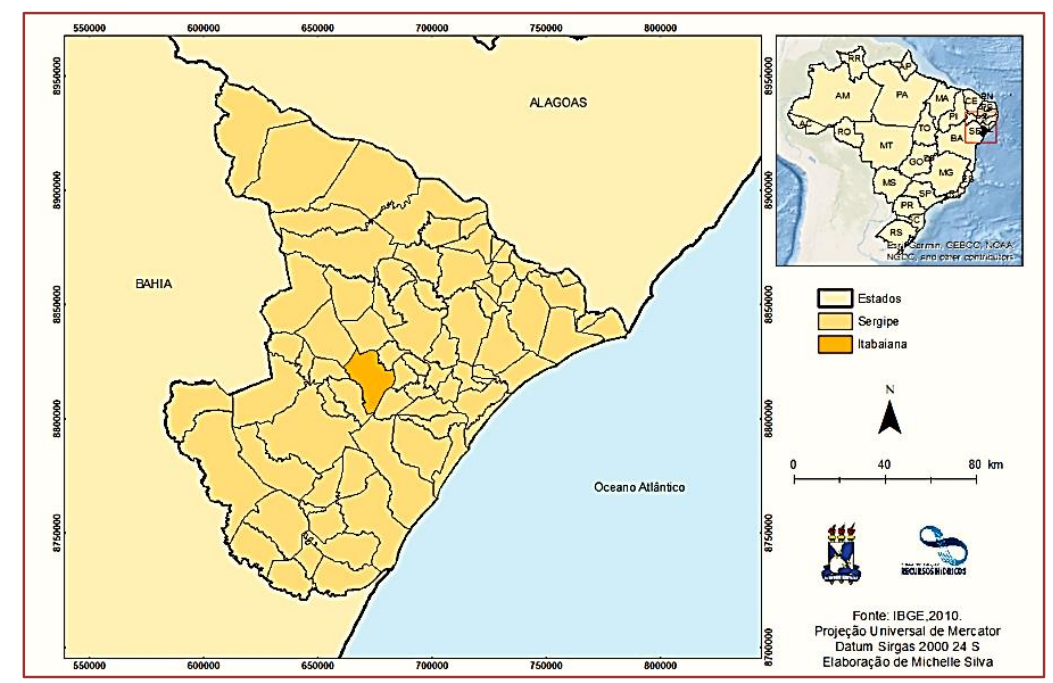




\subsection{MÉTODO DE PENMAN-MONTEITH}

O modelo de estimativa da evapotranspiração de referência através do método de Penman-Monteith (ALLEN et al., 1998), considerado como padrão. Este é um método micrometeorológico que concilia os aspectos aerodinâmicos e termodinâmicos, mas também inclui a resistência ao fluxo de calor sensível e vapor d'água no ar (Ra), e a resistência da superfície (planta) a transferência de vapor d'água (rc), para tal foi utilizado a equação a seguir:

$$
E T_{0}=\frac{0,408 \Delta\left(R_{n}-G\right)+\gamma \frac{900}{T+273} u_{2}\left(e_{s}-e_{a}\right)}{\Delta+\gamma\left(1+0,34 u_{2}\right)}
$$

em que: $\mathrm{ET}_{0}$ - evapotranspiração de referência $\left(\mathrm{mm} \mathrm{d}^{-1}\right) ; \Delta$ - declividade da curva de pressão de vapor de saturação $\left(\mathrm{kPa}^{\circ} \mathrm{C}^{-1}\right) ; \gamma^{*}$ - constante psicrométrica $=0,063 \mathrm{kPa}{ }^{\circ} \mathrm{C}^{-1} ; \mathrm{R}_{\mathrm{n}}$ - saldo de radiação a superfície (MJ $\left.\mathrm{m}^{-2} \mathrm{~d}^{-1}\right)$; $\mathrm{G}$ - fluxo de calor no solo ( $\left.\mathrm{MJ} \mathrm{m} \mathrm{m}^{-2} \mathrm{~d}^{-1}\right)$; T - temperatura média do $\operatorname{ar}\left({ }^{\circ} \mathrm{C}\right) ; \mathrm{U}_{2}$ - velocidade do vento medida a 2 metros de altura $\left(\mathrm{m} \mathrm{s}^{-1}\right)$; $\mathrm{e}_{\mathrm{s}}$ - pressão de saturação de vapor $(\mathrm{kPa}) ; \mathrm{e}_{\mathrm{a}}$ - pressão parcial de vapor $(\mathrm{kPa}) ;\left(\mathrm{e}_{\mathrm{s}}-\mathrm{e}_{\mathrm{a}}\right)$ - déficit de saturação de vapor $(\mathrm{kPa})$.

Para o calculo do saldo de radiação líquida (Rn), utilizou-se da seguinte equação desenvolvida por Sentelhas (1998):

$$
\mathrm{Rn}=0,574 * \mathrm{Qg}
$$

em que: $\mathrm{Qg}=$ irradiância solar global, $\mathrm{MJ} \mathrm{m}^{-2} \mathrm{~d}^{-1}$.

\subsection{MÉTODO DE HARGREAVES - SAMANI}

0 método sugerido por Hargreaves e Samani (1985) para estimativa da evapotranspiração de referência é uma possibilidade para situações em que há carência de dados de radiação solar à superfície, umidade relativa e umidade do vento. A equação é apresentada a seguir:

$$
\mathrm{ET}_{0}=0,0023\left(\mathrm{~T}_{\max }-\mathrm{T}_{\text {min }}\right)^{0,5}\left(\mathrm{~T}_{\text {med }}+17,8\right) \mathrm{Ra}
$$

em que: $\mathrm{T}_{\max }$ é a temperatura máxima do dia, ${ }^{\circ} \mathrm{C} ; \mathrm{T}_{\min }$, a temperatura mínima do dia, ${ }^{\circ} \mathrm{C} ; \mathrm{T}_{\operatorname{med}}$ a temperatura média do dia, ${ }^{\circ} \mathrm{C}$ e $\mathrm{Ra}$, irradiação extraterrestre, $\mathrm{mm} \mathrm{d}^{-1}$.

\subsection{MÉTODO DE PRIESTLEY-TAYLOR}

O Método de Priestley-Taylor é uma simplificação da equação de Penman-Monteith. Apresenta certa vantagem, pois são exigidos poucos dados para sua estimativa (PRIESTLEY; TAYLOR, 1972).

$$
\mathrm{ET}_{0}=1,26 \times[\Delta /(\gamma+\Delta)] *(\mathrm{Rn}-\mathrm{G})
$$

em que: $\mathrm{ET}_{0}=$ evapotranspiração de referência $\left(\mathrm{mm} \mathrm{d}^{-1}\right) ; \gamma=$ constante psicrométrica $\left(\mathrm{kPa}^{\circ} \mathrm{O}^{-1}\right) ; \Delta=$ derivada da função de saturação de vapor de água; $\mathrm{Rn}=$ radiação útil recebida pela cultura de referência $\left(\mathrm{mm} \mathrm{d}^{-1}\right) ; \mathrm{G}=$ fluxo de calor recebido pelo solo $\left(\mathrm{mm} \mathrm{d}^{-1}\right)$. 


\section{RESULTADOS E DISCUSSÃO}

A Figura 2 apresenta a série de precipitações de 2017 e 2018 para o município em estudo. Podemos observar que os índices pluviométricos se iniciam em fevereiro, aumentam consideravelmente em maio e diminuem em outubro. O município presentou pico diário de até $45 \mathrm{~mm}$ no mês de junho e dias sem precipitação, especialmente em novembro. Em comparação com regiões semiáridas, as chuvas em Itabaiana são consideradas bem distribuídas, ao longo do ano.

Figura 2. Distribuição das precipitações no município de Itabaiana/SE

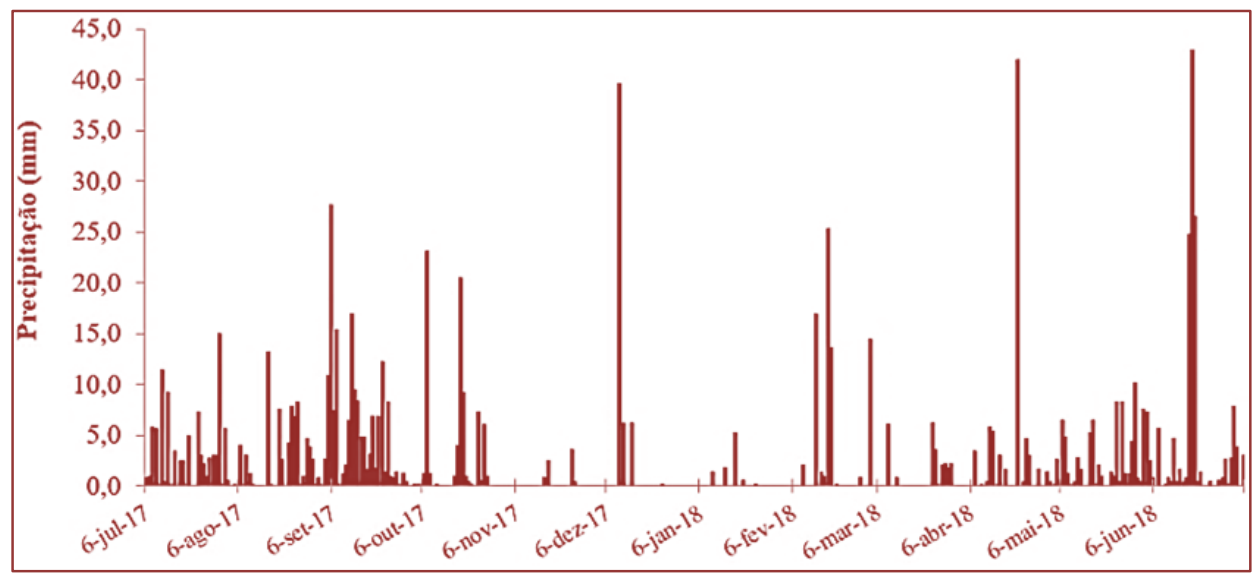

As correlações da $\mathrm{ET}_{0}$ foram realizados entre os métodos de Hargreaves-Samani (H-S) e Penman-Monteith (P-M), como mostra no Figura 3, e determinação da ET 0 entre os métodos Priestley - Taylor (P-T) e Penman-Monteith (Figura 4), onde podemos observar uma correlação positiva de ambos os métodos com regressão linear de ajuste $\mathrm{R}^{2}$ de 0,6258 para $\mathrm{H}-\mathrm{S} / \mathrm{P}-\mathrm{M}$ e $\mathrm{R}^{2}$ de 0,6102 para P-T/P-M. A correlação foi classificada como alta. De acordo com Hopkins (2014), podendo ser adotados para eventuais estudos de alocação de água e balanços hídricos.

Figura 3. Correlação ET 0 H-S/P-M

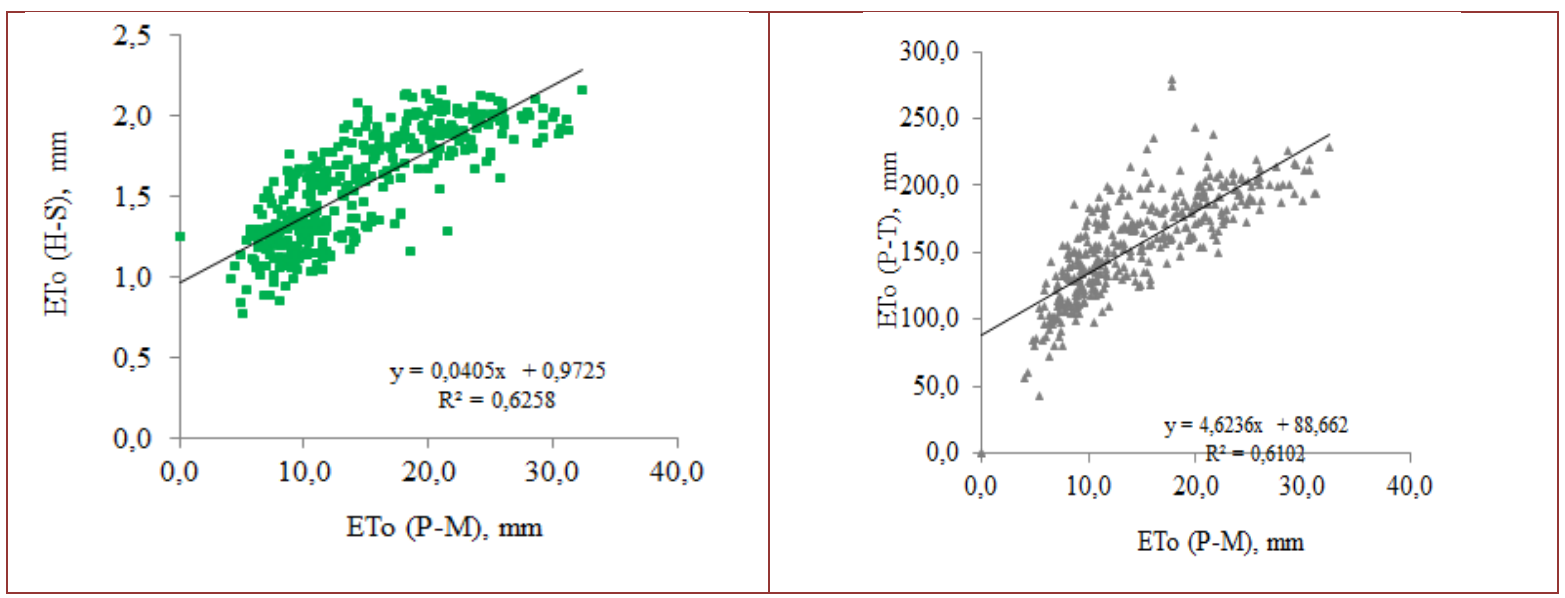

Através da Figura 5 é possível analisar o balanço hídrico mensal do município de Itabaiana. As precipitações analisadas estão para o período de julho de 2017 até julho de 2018. A evapotranspiração potencial $\left(\mathrm{ET}_{0}\right)$ e evapotranspiração real (ETR) foram sobrepostas, e se observa uma correlação entre $\mathrm{ET}_{0}$ e ETR nos meses de junho, julho, agosto e setembro, coincidindo com o período chuvoso. Enquanto que nos demais meses se percebe a diferença dos mesmos pela ausência de chuvas. Existindo assim uma forte correlação proporcional entre ET 0 e ETR com as precipitações. 
Figura 5. Balanço hídrico normal mensal.

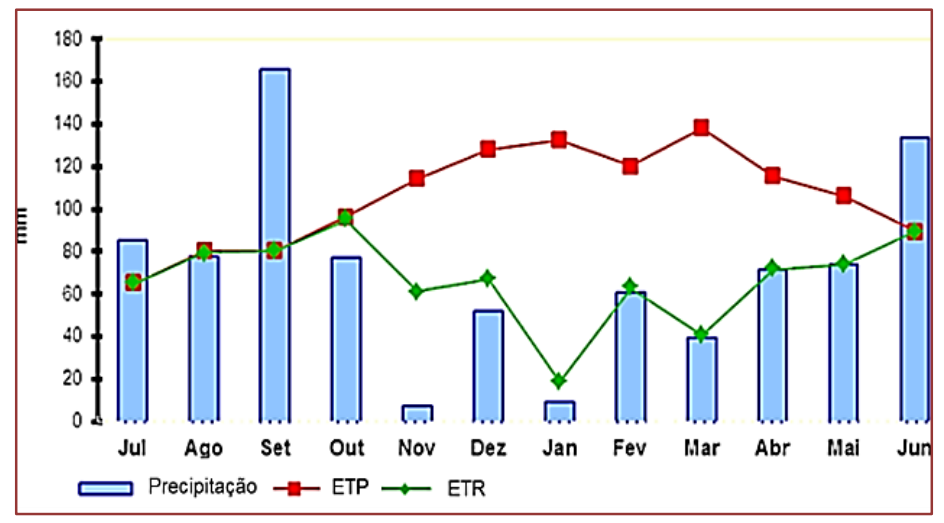

Para a região de Itabaiana, o extrato do balanço hídrico apresentado na Figura 6 mostra que o período chuvoso se apresenta de maneira efetiva, entre os meses de junho a outubro, indicando reposições hídricas e excedentes, com a apresentação de um pequeno veranico em agosto (variação entre 0 e $54 \mathrm{~mm}$ ). Entre outubro e maio, foram considerados meses secos, com a ocorrência de deficiência hídrica na maioria deles, variando entre 0 e $-114 \mathrm{~mm}$.

Figura 6. Extrato do balanço hídrico mensal

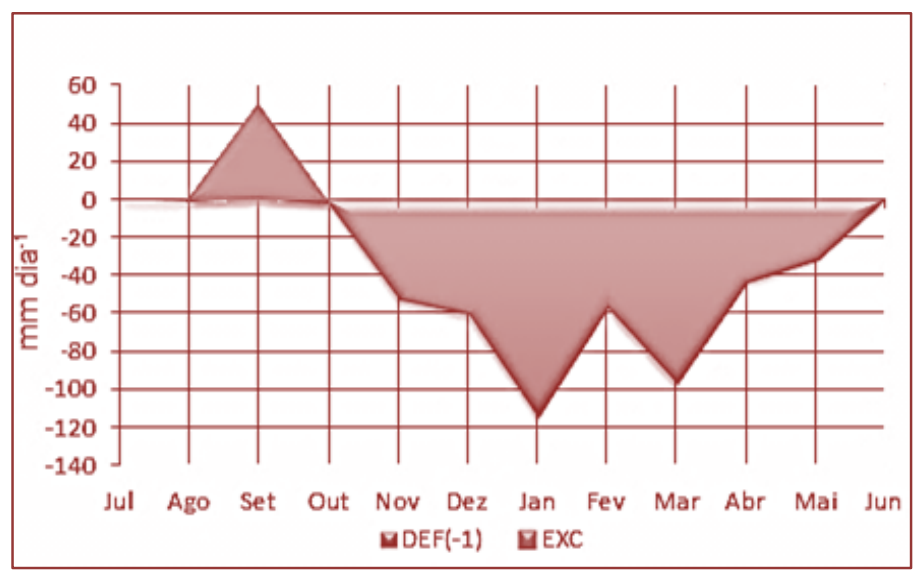

O conhecimento da capacidade máxima que um solo pode reter água (CAD) em uma determinada região é importante para fins de gestão hídrica, dimensionamentos agrícolas, para cálculo de escoamento superficial, dentre outros (DE ALMEIDA, 2016). Foi construída a curva do CAD em que se adotou um CAD de $100 \mathrm{~mm}$ (Figura 7). Observa-se que a quantidade de chuvas para uma vasta parcela de meses do ano não é suficiente para armazenamento de água no solo, apenas o mês de setembro atingiu sua capacidade máxima. Isso configura um grande período de estiagem na área estudada, necessitando, então, de reposição dessa parcela hídrica ausente. 
Figura 7. Capacidade de armazenamento (CAD) e Armazenamento mensal (ARM).

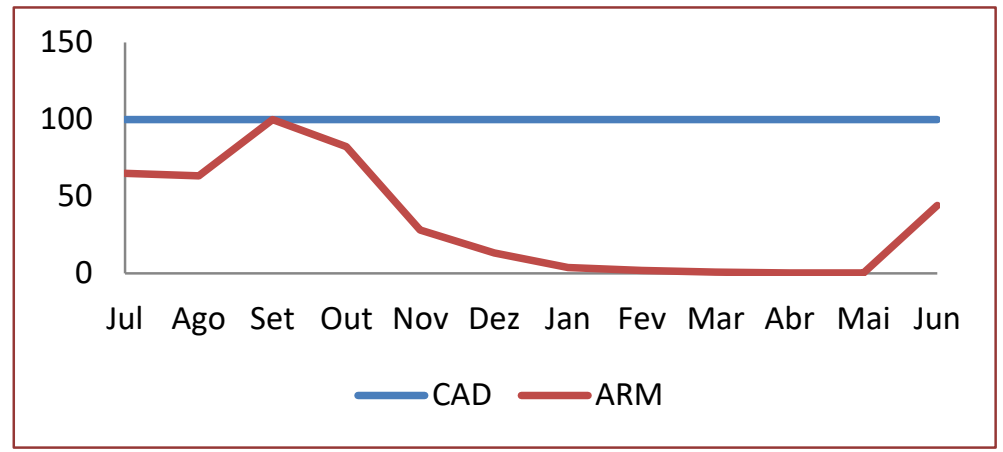

\section{CONCLUSÕES}

Os resultados apontam que o período de excedente hídrico compreende a estação do inverno e o início da primavera, representando o abastecimento d'água no solo. A deficiência hídrica abrange o verão e o outono, indicando altas taxas de evapotranspiração.

Com a redução da precipitação pluviométrica, nos meses de outubro a maio, é evidenciada a carência de armazenamento da d'água no solo. Portanto, esse período de estiagem necessita de maior alerta no manejo da irrigação para culturas que necessitam da manutenção hídrica.

Os métodos de estimativa da evapotranspiração de referência que mais se aproximaram, apresentando um significativo coeficiente de ajuste, foram Penman-Monteith e Hargreaves-Samani, indicando que $62,8 \%$ da variável dependente consegue ser explicada pelo modelo.

Durante o período chuvoso, as Evapotranspirações Real e Potencial tendem a se aproximar e durante o período seco, divergem entre si, mostrando que seus comportamentos estão fortemente ligados à precipitação.

\section{AGRADECIMENTOS}

O presente trabalho foi realizado com o apoio da Coordenação de Aperfeiçoamento de Pessoal de Nível Superior - Brasil (CAPES) - Código de Financiamento 001

\section{REFERÊNCIAS BIBLIOGRÁFICAS}

[1] ALLEN, R. G.; PEREIRA, L. S.; RAES, D.; SMITH, M. Crop evapotranspiration: guidelines for computing crop water requirements. Rome: FAO, 1998. 297p. (FAO Irrigation and Drainage Paper 56).

[2] DE ALMEIDA, J. D. M.; DE SOUZA, J. O. P.; DE BARROS CORRÊA, A. C. Dinâmica e caracterização fluvial da bacia do riacho grande, Serra Talhada-PE: Abordagem da conectividade da paisagem. Geo UERJ, n. 28, p. 308-331, 2016.

[3] BERGAMASCHI, H.; BERLATO, M. A.; MATZENAUER, R.; FONTANA, D. C.; CUNHA, G. R.; SANTOS, M. L. V.; FARIAS, J. R. B.; BARNI, N. A. Agrometeorologia aplicada à irrigação. Porto Alegre: Ed. Universidade, 2 ed.,1999.

[4] BERNARDO, S.; SOARES, A. A.; MONTOVANI, E. C. Manual de irrigação. 8. Ed. Viçosa: UFV, 2006. 625 p.

[5] BURMAN, R. D.; NIXON, P. R.; WRIGTH, J. L.; PRUITT, W. O. Water requirements. In: JENSEN, M. E., ed. Design and operation of farm irrigation system. St. Joseph: ASAE, cap. 6, p.189 - 232, 1983.

[6] CARVALHO, D. M.; Costa, J. E. A Intervenção do Estado em Infraestrutura e o Processo de Circulação de Hortifrutigranjeiro em Itabaiana/SE. Scientia Plena, v.6, n.3, 2010.

[7] DE ALMEIDA, JOANA D. M.; DE SOUZA, J. O. P.; DE BARROS C., A. C.. Dinâmica e caracterização fluvial da bacia do riacho grande, Serra Talhada-PE: Abordagem da conectividade da paisagem. Geo UERJ, n. 28, p. 308-331, 2016.

[8] DINIZ, M. T. M.; Medeiros, S. C.; Cunha, C. J. Sistemas atmosféricos atuantes e diversidade pluviométrica em Sergipe. Boletim Goiano de Geografia (Online). Goiânia, v. 34, n. 1, p. 17-34, 2014. 
[9] DOORENBOS, J.; PRUITT, J. O. Guidelines for predicting crop water requeriments. Rome: FA0, 179 p., 1977. (FAO Irrigation and Drainage Paper, 24).

[10] FARIA, M. A. SIMPÓSIO DE MANEJO DE IRRIGAÇÂO. Poços de Calda, MG- Brasil, 1998. 367 p.

[11] HARGREAVES, G. H.; SAMANI, Z. A. Reference crop evapotranspiration from temperature. Appl. Eng. Agric, v.1, n.2, p.96-99, 1985.

[12] HOPKINS, W. G. Correlation coefficient. Disponível em: http://www.sportsci.org/resource/stats/correl.html. Acesso em: 07/07/2018.

[13] INMET. Instituto de Meteorologia. Disponível em: www.inmet.gov.br. Acesso em: 06/07/2018.

[14] INSTITUTO BRASILEIRO DE GEOGRAFIA. Indicadores de desenvolvimento sustentável: Brasil 2015. IBGE, 2015.

[15] LACERDA, Z. C.; TURCO, J. E. P. Estimation methods of reference evapotranspiration ( $\mathrm{ET}_{0}$ ) for Uberlândia MG. Engenharia Agrícola, Jaboticabal, v.35, n.1, p.27-38, 2015.

[16] MARTINEZ, J. M. M. et al. A simulation model for predicting hourly pan evaporation from meteorological data. Journal of Hydrology, Amsterdam, v. 318, p. 250-261, 2006.

[17] PENMAN, H. L. Natural evaporation from open water, bare soil and grass. Proceedings of Royal Society-Series A, London, v.193, n.1, p.120-145, 1948.

[18] PRIESTLEY, C. H. B.; TAYLOR, R. J. On the assessment of surface heat flux and evaporation using large-scale parameters. Monthly Weather Review, Boston, v.100, n.2, p.81-92, 1972.

[19] SENTELHAS, P. C. Estimativa diária da evapotranspiração de referência com dados de estação meteorológica convencional e automática. 1998. Tese de Doutorado. Escola Superior de Agricultura Luiz de Queiroz da Universidade de São Paulo.

[20] SILVA, V. P. R. On climate variability in Northeast of Brazil. Journal of Arid Environments n.58, p.575-596, 2004.

[21] SILVEIRA, ANDRÉ L.; LOUZADA, JOSÉ A.; BELTRAME, LAWSON F. S. Infiltração e Armazenamento no solo. In: TUCCI, Carlos E. M. Hidrologia Ciência e Aplicação. 4. ed. Porto Alegre: UFRGS, 2015. Cap. 5. p. 335-365.

[22] SOUSA, I. F. DE; SILVA, V. P. R. DA; SABINO, F. G.; NETTO, A. DE O.; SILVA, B. K. N.; AZEVEDO, P. V. Evapotranspiração de referência nos perímetros irrigados do estado de Sergipe. Revista Brasileira de Engenharia Agrícola e Ambiental, v.14, p.633-644, 2010.

[23] THORNTHWAITE, C. W., 1948. An approach toward a regional classification of climate. Geogr. Rev. 38: 55-94. 


\section{Capitulo 13}

\section{Consumo de água em meios de hospedagem brasileiros}

\section{Jhonata Wesley Gomes Barbosa}

Evany Adriane Maria Dias Batista

Diogo Henrique Fernandes da Paz.

Resumo: 0 consumo irregular de água pode causar diversos problemas que colaboram para impactos ambientais. Essa pesquisa tem como objetivo realizar uma revisão teórica em artigos relacionados ao consumo de água pelos empreendimentos de hotelaria e hospedagem. Para realização da análise foi selecionado 11 artigos ao qual forneceram dados de 28 empreendimentos, sendo eles nacionais e internacionais. Foi realizado parâmetros comparativos de consumo dos empreendimentos, demonstrações estatísticas e sistematização de gráficos visando apresentar a situação real do consumo dos hotéis analisados com relação ao consumo de unidades hoteleiras, lazer, cozinha, lavanderia, consumo de funcionários e hóspedes. Verificou-se que alguns hotéis que apresentam um número de quartos e área menor, apresentaram um valor de consumo de água até maior que empreendimento com área e quartos maior, refletindo que as características geográficas, temporada de funcionamento e políticas internas de redução ao desperdício e inovação do consumo tem sua relevância. Dessa forma infere-se que há uma grande necessidade de implementação de um sistema de gerenciamento ambiental voltado aos recursos hídricos e consumo de água em toda rede hoteleira.

Palavras-Chave: Consumo de água. Empreendimentos Hoteleiros. Recursos Hídricos 


\section{INTRODUÇÃO}

O Instituto Brasileiro de Turismo (EMBRATUR, 2015) aponta que o turismo é responsável por 9\% do Produto Interno Bruto (PIB) mundial, 30\% das exportações de serviços e 6\% do comércio internacional. Porém, existe uma crescente preocupação dos seus consumidores com a relação entre os empreendimentos da indústria e a sustentabilidade e preservação dos recursos naturais, destacando-se as questões que envolve o consumo e reaproveitamento de água. Dados da Idral Soluções Profissionais (2019) mostram que 87\% dos consumidores preferem comprar de empresas sustentáveis. Sendo assim, a redução do desperdício da água tende a atrair consumidores para os empreendimentos, rendendo lucro para a indústria hoteleira.

Conforme aponta De Conto (2005 apud LAMAS et al., 2016):

Por conta disso, há uma preocupação dos hotéis em ações ambientais que abrangem as áreas de energia, resíduos sólidos, água, efluentes, emissões, educação ambiental, programas de sensibilização, aspectos de mercado (legislação, tecnologias) e fornecedores.

De acordo com Schenini (2005), a rede hoteleira atribui sua sobrevivência a atratividade da localização que o hotel está situado, e no Brasil essa realidade corrobora para uma potencialização, por conta das riquezas naturais do país. Porém, as redes de hotéis ainda possuem dificuldades quando se trata de um sistema de gerenciamento ambiental que procure reduzir o consumo dos recursos, inclusive o da água.

Segundo Lamas et al. (2016), 75\% dos meios de hospedagem não possuem conhecimento sobre o impacto que podem causar ao meio ambiente ou tem pouco conhecimento a respeito. Diante do exposto, fica evidente a necessidade de um estudo aprofundado em redes de hotéis que corroborem para levantamentos de indicadores, visando contribuir para que os empreendimentos se adequem as necessidades de sustentabilidade com relação a gestão de água.

Portanto, este estudo tem como objetivo aprofundar as questões acerca do consumo de água da indústria hoteleira, com objetivo de analisar a situação atual, realizar levantamento de indicadores das empresas, para entender a sua realidade, que pode contribuir para a sustentabilidade das instalações, o desenvolvimento financeiro e de imagem, para provar que as ações destinadas a redução de desperdício trarão benefícios econômicos para o hotel.

\section{METODOLOGIA}

Segundo o Instituto Brasileiro de Geografia e Estatística (IBGE, 2016), no Brasil estima-se que existem 31,3 mil estabelecimentos de hospedagem, sendo observado que aproximadamente 1 milhão de unidades são habitacionais e 2,4 milhões de leitos. Os dados levantados pelo IBGE (2013) se traduzem na amostra quantitativa onde esses estabelecimentos se apresentam na proporção de $47,9 \%$ composto por hotéis, $31,9 \%$ por pousadas e $14,2 \%$ por motéis.

Para a composição dessa pesquisa, foi realizada uma revisão bibliográfica com o objetivo de obter um panorama sobre a realidade atual dos meios de hospedagem em relação ao consumo de água, de forma que fosse compreendido as suas necessidades, levando em consideração as mais diversas áreas ao qual os empreendimentos se encontram e sua dinâmica de consumo e desperdício. Foram obtidos dados de 35 meios de hospedagem baseados nas pesquisas avaliadas, tanto no âmbito nacional quanto internacional, visto que as características geográficas e climáticas influenciam fortemente na cultura de consumo dos empreendimentos.

Dessa forma, foram levantados indicadores para a avaliação da situação da rede hoteleira e seu consumo. Os indicadores levantados foram: Tipologia de empreendimento, área construída, área verde (área de irrigação), número de quartos (unidade), média de hóspedes por mês, número de funcionários que trabalham no hotel, consumo de água nas atividades da cozinha, lavanderia, limpeza e jardins, consumo por hóspedes, consumo por funcionário, área da piscina e quantidade de água consumida na piscina. 


\section{RESULTADOS E DISCUSSÕES}

A seguir são apresentados os dados dos 35 hotéis analisados, onde suas características variam por conta da diversidade de suas atividades e localização, onde alguns estão situados em território nacional e outros no exterior, variando também suas características como: área construída $\left(\mathrm{m}^{2}\right)$, período de funcionamento e atividades realizadas em cada hotel.

A Figura 1 apresenta o consumo diário dos hotéis analisados. Observou-se que os valores variaram de $1.477 \mathrm{~L} /$ dia a $108.993 \mathrm{~L} /$ dia.

Figura 1 - Consumo diário de água dos hotéis analisados.

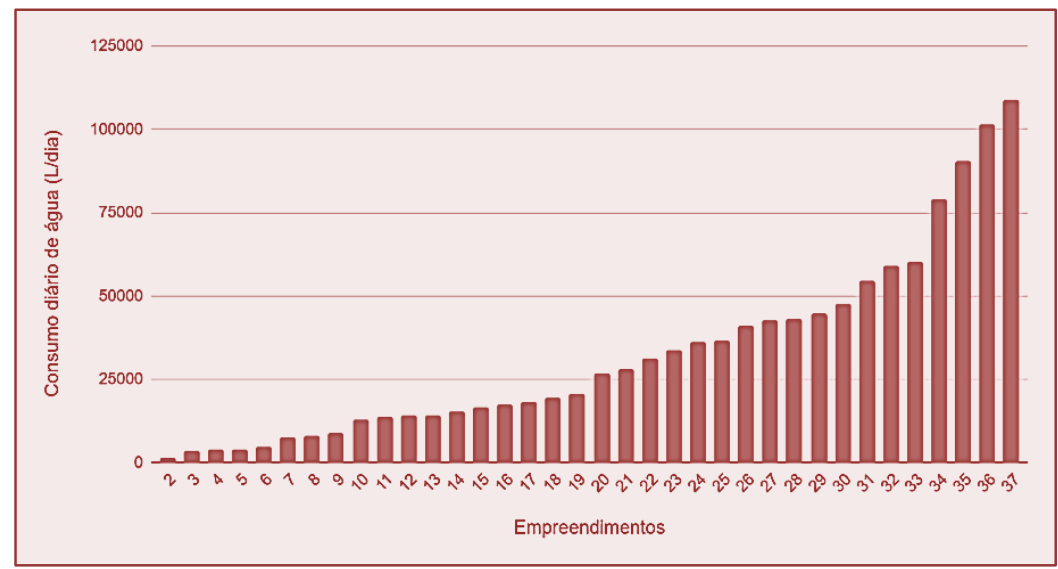

Observou-se que as características dos empreendimentos influenciam diretamente nos percentuais de consumo diário de água dos estabelecimentos hoteleiros. Analisando de forma individual, alguns empreendimentos de maior porte apresentaram um consumo diário de água inferior a outros de menor porte, o que tem sido gerado por diferenças na metodologia de coleta de dados.

Por outro lado, observou-se que o porte dos hotéis influencia diretamente na quantidade de água produzida. A Figura 2 apresenta o índice de consumo diário de água em relação ao porte dos estabelecimentos, e a Figura 3 apresenta a correlação entre o consumo de água e a quantidade de apartamentos (Unidades Hoteleiras - UH).

O tamanho dos meios de hospedagens é definido pela quantidade de Unidades Habitacionais (UHs) como: pequeno porte (até $50 \mathrm{UHs}$ ), médio porte (de 51 até $100 \mathrm{UHs}$ ) e grande porte (acima de $100 \mathrm{UHs}$ ).

Figura 2 - Consumo diário d e água dos hotéis com relação: (a) ao porte; (b) ao número de apartamentos

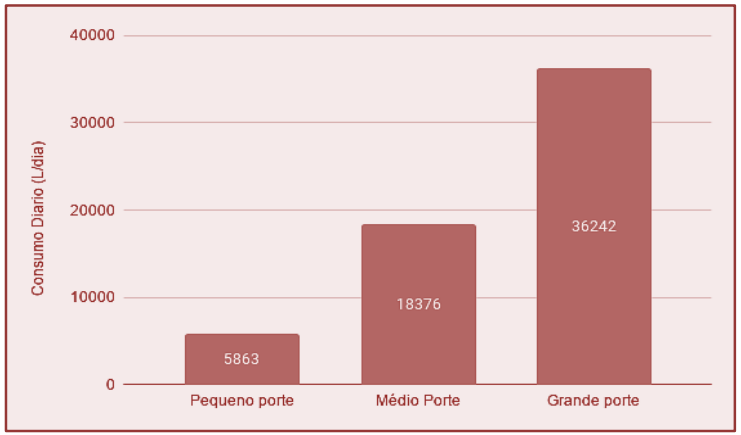

(a)

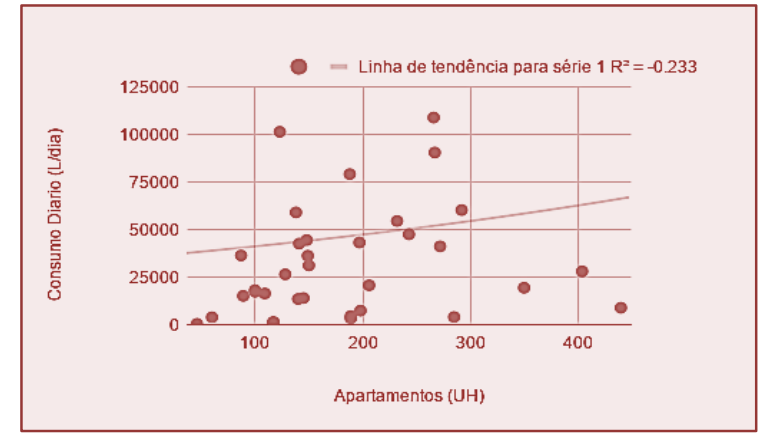

(b)

Observou-se que a quantidade média de água dos hotéis sofre influência direta do porte do empreendimento. Os meios de hospedagem podem ter um alto consumo de água, dependendo da 
capacidade de acomodação de cada hotel, padrão, e o tipo de instalações e serviços prestados, conforme apontado também por Kuuder et al. (2014). Hotéis de luxo consomem grandes quantidades de água para fins de lazer, como piscinas, spas e irrigação de campos de golfe.

É possível verificar que a quantidade de água possui uma linha de tendência crescente com o aumento do número de apartamentos, apesar de ter sido obtido uma baixa correlação entre os hotéis analisados, o que se explica pelo fato de que existem outros critérios que influenciam no consumo de água. A Figura 3 apresenta o comparativo do consumo de água com a classificação hoteleira do Sistema Brasileiro de Classificação de Meios de Hospedagem (SBClass), onde se avaliou hotéis que possuíam de 2 a 5 estrelas.

Figura 3 - Consumo diário de água dos hotéis com relação as suas estrelas.

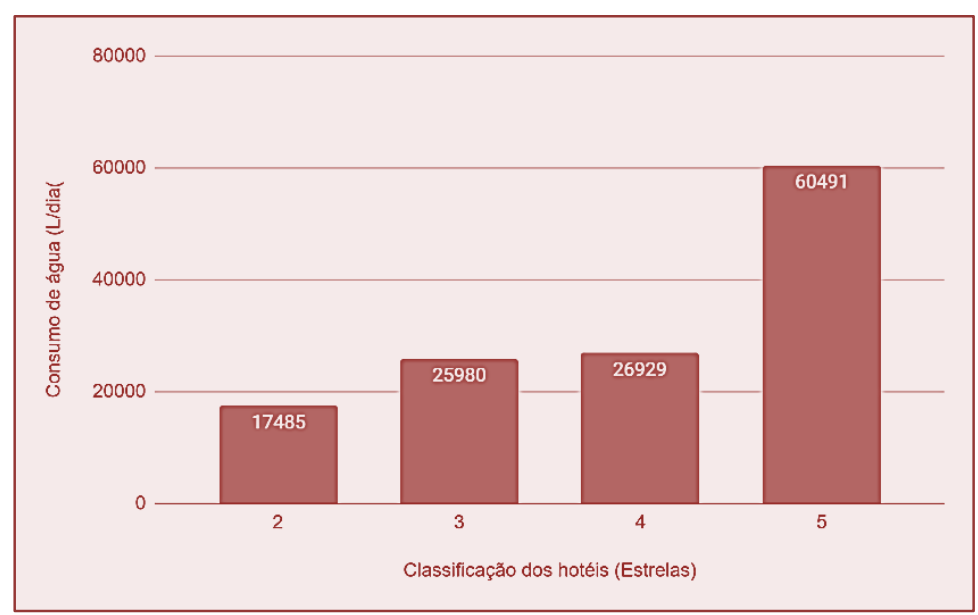

Observou-se que os empreendimentos classificados com 5 estrelas, consomem em média mais que o dobro do consumo dos classificados como 4 estrelas, isso acontece porque os hotéis d5 estrelas apresentam mais atividades que demandam um maior consumo de água, como: lavanderias, salões de beleza, academias, spa e troca diária de roupas de cama e banho. Os hotéis de 3 e 4 estrelas demonstraram uma proximidade com relação ao seu consumo de água, porém os hotéis de 2 estrelas por mais que estejam abaixo e distantes com relação ao consumo dos demais, demonstraram um alto consumo de água, levando-se em consideração que em termos de serviços são inferiores aos demais.

A Figura 4 demonstra a variabilidade do consumo de água por hospedes dos empreendimentos analisados nos artigos.

Figura 4 - Consumo diário de água dos hotéis por hospede.

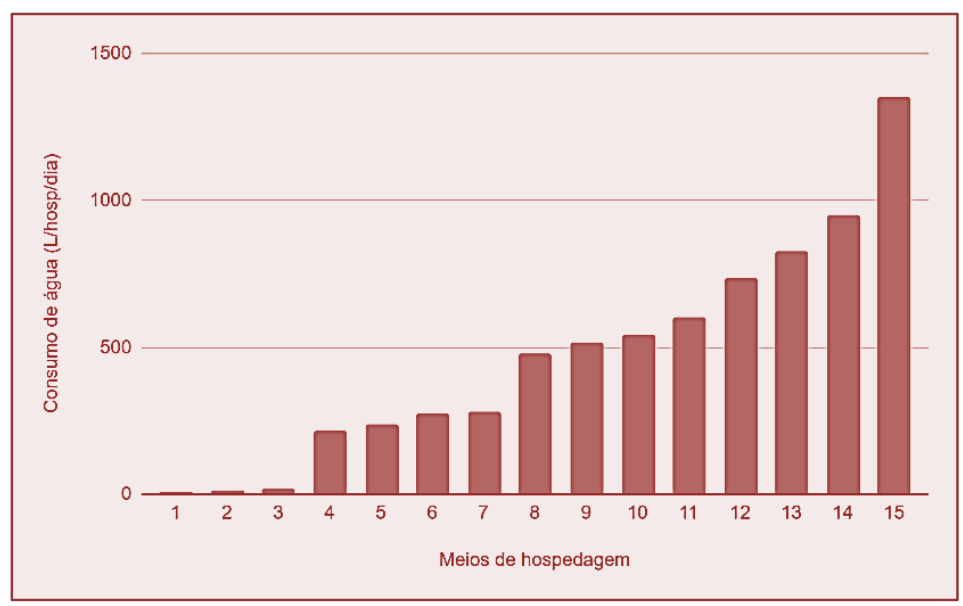


Verificou-se, portanto, que o consumo médio de água por hóspede por dia varia entre 5 e 1353 L/hosp./dia. Pode ser observada uma grande variação no consumo per capita de água em outras pesquisas realizadas. Meade e González-Morel (1999) obteve uma variação de 438 a 1236 l/hosp./dia, enquanto que Bohdanowicz e Martinac (2007) obteve de 215 a 515 l/hosp./dia.

Foi constatado que na maioria dos artigos analisados, não são disponibilizados os valores relacionados ao número de hóspedes e funcionários, e o consumo per capita. Porém, com o quantitativo que foi apresentado, foi possível destacar que o consumo dos hóspedes contribui de forma destacada para o consumo geral dos empreendimentos, onde dependendo da política do empreendimento em relação a sensibilização dos seus clientes e cooperadores quanto ao não desperdício e reaproveitamento, esses valores podem diminuir.

Um dos fatores que corroboram para o aumento do consumo de água na rede hoteleira é a extensão da área construída dos empreendimentos, por possuir correlação com a quantidade de apartamentos e em especial por questão de limpeza e manutenção. A Figura 5 apresenta a relação entre o consumo dos empreendimentos e a área construída e área verde.

Observou-se que alguns empreendimentos com área menor que outros apresentaram um gasto de água maior, porém isso se deve à prática que alguns hotéis já utilizam em relação ao reaproveitamento de água, quantidade de quartos, se possuem ou lavanderia. Como exemplo um dos hotéis, que possui uma área de $76890,3 \mathrm{~m}^{2}$ e utiliza água proveniente do mar por osmose em suas atividades. Obteve uma variação de 0,2 a $11,8 \mathrm{~L} / \mathrm{m}^{2} /$ dia.

Figura 5 - Relação entre consumo (L/dia) por: (a) área construída, (b) área verde
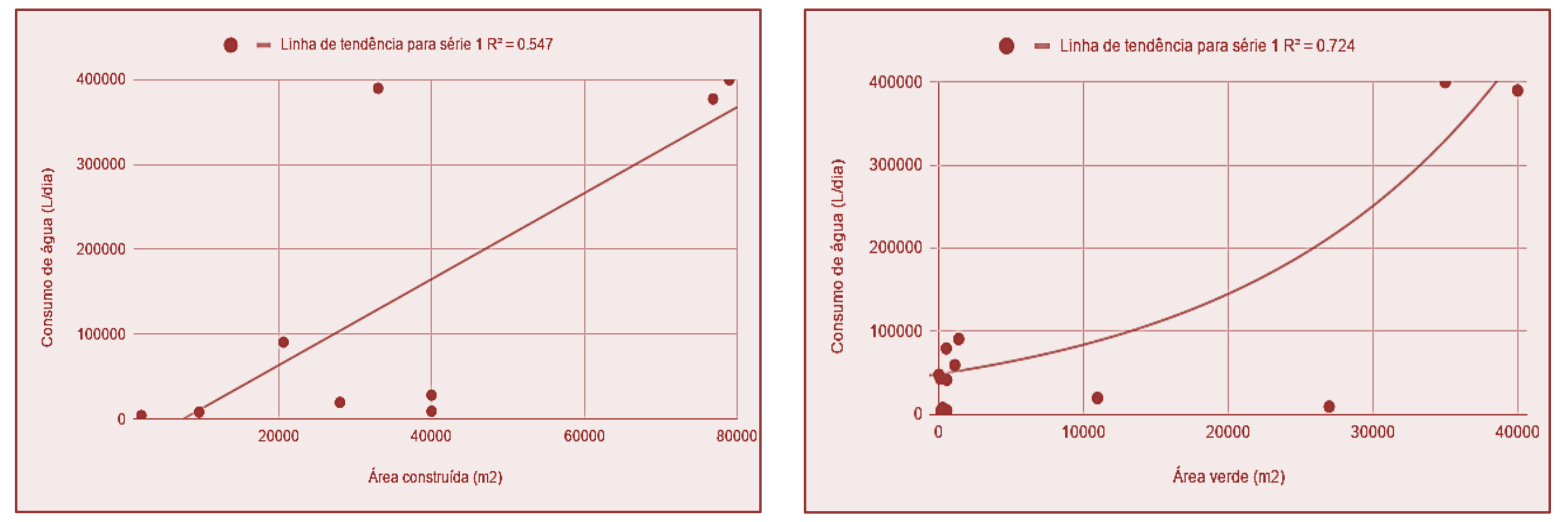

Hotéis de maiores extensões é comum apresentarem áreas verdes como um dos fatores de consumo de água, através das irrigações, principalmente com o aumento do interesse dos consumidores em passar temporada de férias e feriados em lugares com vasta área verde em contato com o meio natural.

Em relação à setorização do consumo, constata-se que o uso da água nos hotéis é amplo e inclui cozinha, lavanderia, banheiros, aquecimento, irrigação, dentre outros.

Com relação aos setores de lavanderia e cozinha, observou-se que, segundo Deng e Brunet (2002 apud BARBERÁN et al., 2013), lavanderias são responsáveis por $47 \%$ do consumo de água, e cozinhas são responsáveis por $30 \%$ do consumo. Porém, hotéis sem lavanderia consomem $55 \%$ de água na cozinha. Dessa forma as Figuras 6 e 7 demonstram segundo os dados levantados nos artigos, o panorama com relação ao consumo em empreendimentos com lavanderias e cozinhas 
Figura 6 - Consumo diário de água com relação as lavanderias.

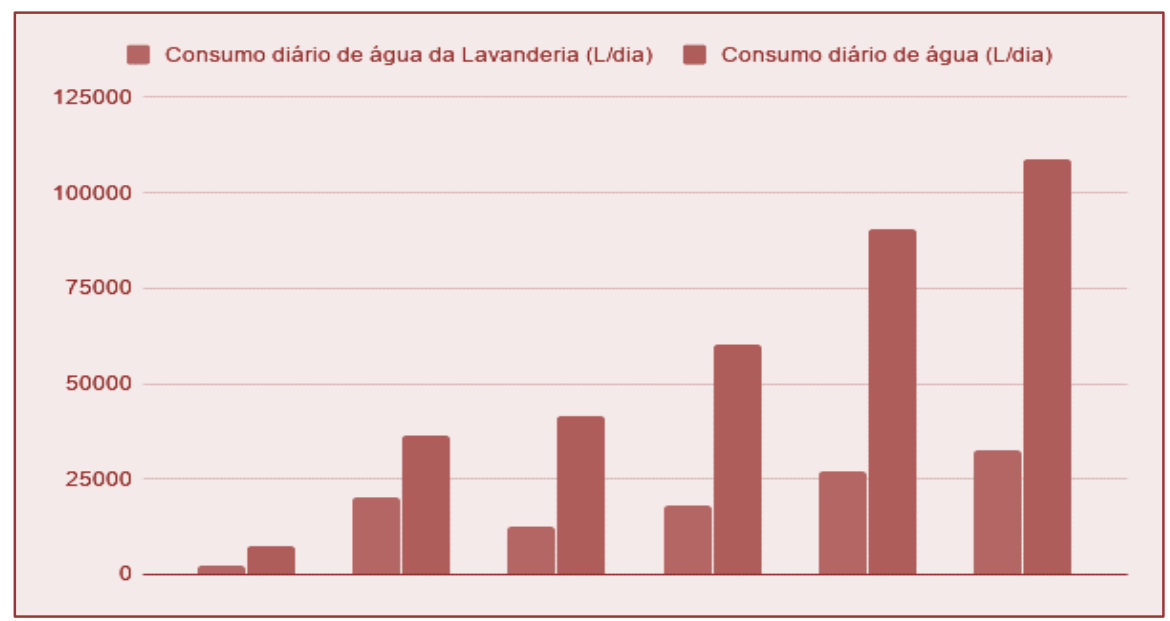

Figura 7 - Consumo diário de água com relação a cozinha

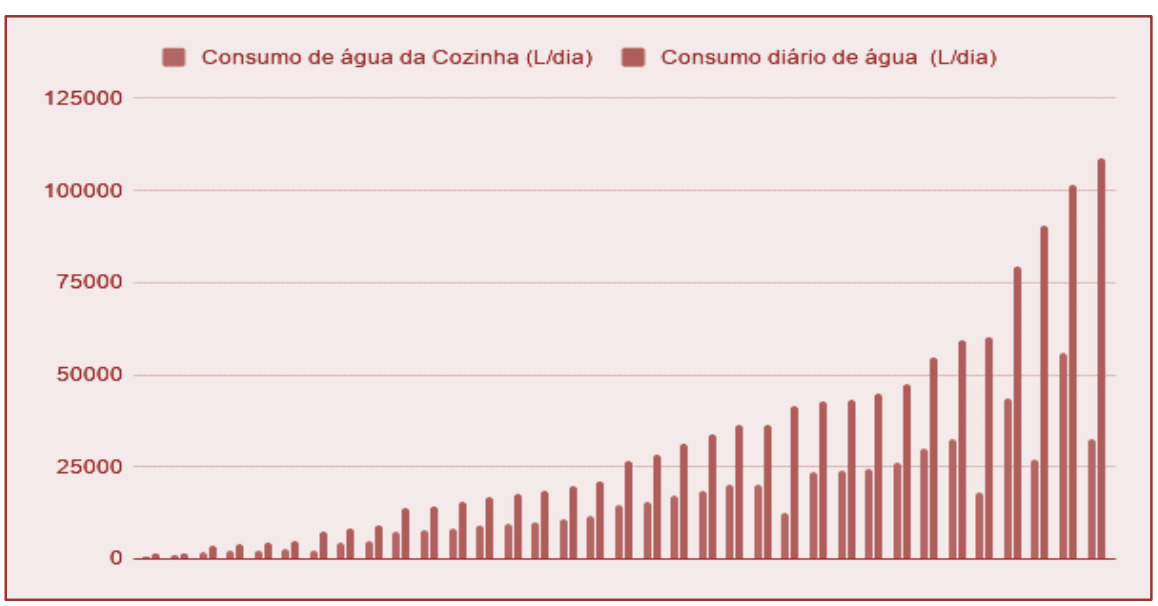

Os dados dispostos nos gráficos apresentam parâmetros relevantes das empresas analisadas, de forma que nem todas as empresas hoteleiras demonstraram possuir lavanderias nos artigos, portanto, as empresas que não apresentam lavanderias, possuem um destaque maior em suas cozinhas, relacionados ao consumo diário de água do hotel.

Nascimento e Santana (2014), ao analisar o consumo de água em dois hotéis de Brasília, observou que o empreendimento que possui uma infraestrutura com sala para eventos, restaurantes abertos para público, piscina e sauna tem um elevado consumo de água.

\section{CONCLUSÃO}

Conforme os resultados finais do levantamento de dados dessa pesquisa, relacionados a todos os empreendimentos citados nos artigos analisados, entende-se que a indústria hoteleira se apresenta como uma grande consumidora dos recursos hídricos e que seu consumo não fiscalizado pode ser um potencial agravador ambiental em todo planeta. Verificou-se que uma das situações mais preocupantes são a de empreendimentos que mesmo com quantidade de quartos e apartamentos inferiores a outros, tem uma demanda de consumo de água bastante elevada, enquanto outros empreendimentos baseados na sua quantidade de leitos apresentam um consumo equilibrado.

Para reduzir o consumo de água em hotéis, são necessárias práticas de conservação da água, que incluem uso de dispositivos que economizam água, chuveiros e vasos sanitários de baixa vazão, aeradores de pia, manutenção de equipamentos e eficiência na irrigação. 
Dessa forma, com o crescimento das preocupações ambientais se apresentando como um dos fatores que atraem os hóspedes no momento de avaliar o lugar onde vão se hospedar, supõem-se que os empreendimentos continuarão no caminho para uma regulação de consumo dos recursos para reduzir os níveis de desperdício que corroboram para os impactos ambientais, destacando-se o consumo de água em suas atividades e acomodações. Contudo se faz necessário incluir um plano de gestão de água nos empreendimentos visando um maior reaproveitamento de água, reduzindo o desperdício dos recursos hídricos.

\section{REFERÊNCIAS}

[1] BARBERÁN, R., EGEA, P. RENTERIA, P.G. SALVADOR, M. (2013). "Evaluation of water saving measures in hotels: A Spanish case study”. International Journal of Hospitality Management, n. 34, pp. 807-818.

[2] BELATO, N.D. VIEIRA, H. “Análise da Viabilidade Econômica de Um Sistema de Captação de Águas Pluviais em Um Hotel”. Disponível em: <http://repositorio.unis.edu.br/handle/prefix/640> Acesso em 3 de Jun,2020.

[3] BOHDANOWICZ, P.; MARTINAC, I. (2007). “Determinants and benchmarking of resource consumption in hotels - Case study of Hilton international and Scandic in Europe. Energy and Buildings 39 (1), 82-95.

[4] CARRASQUEIRA, L.S. LIMA, A. C. T. O. ANDRADE, M. L. FREITAS, P.C. FERREIRA, L. C. S. NOBRE, F. J. V. FERREIRA, B. C. S. (2019). "Reuso de águas cinzas em empreendimentos comerciais: um estudo de caso em edifício hoteleiro de Belo Horizonte”. Brazilian Journal of Development, v.5, n.7, pp.10028 - 10035.

[5] “Como Hotéis, Motéis e Pousadas Podem Reutilizar a Água?”. Disponível em:

[6] <http://www.Idral.com.br/2019/09/23/como-hoteis-podem-reutilizar-a-agua/> Acesso em 16 Jun. 2020.

[7] EMBRATUR, “Turismo contribui com 9\% do PIB mundial”. Disponível em:

<http://www.embratur.gov.br/piembraturnew/opencms/salaImprensa/artigos/arquivos/Turismo_contribui_com_9 _do_PIB_mundial.html> Acesso em 17 Jul.2020.

[8] GOSSLING, S. (2015). “New performance indicators for water management in tourism”. Tourism Management, n.46, pp. $233-244$.

[9] HOCAOGLU, S.M. (2017)." Evaluations of on-site wastewater reuse alternatives for hotels through water balance". Resources, Conservation and Recycling, n.122, pp. $43-50$.

[10] IBGE, "Brasil tem 2,4 milhões de leitos em sua rede de hospedagem”. Disponível em: <https://agenciadenoticias.ibge.gov.br/agencia-sala-de-imprensa/2013-agencia-de-noticias/releases/14786-brasiltem-2-4-milhoes-de-leitos-em-sua-rede-de-hospedagem> Acesso em 17 Jul.2020.

[11] ITB, "Perdas de Água 2020 (SNIS 2018): Desafios Para Disponibilidade Hídrica e Avanço da Eficiência do Saneamento Básico". Disponível em:

[12] <http://www.tratabrasil.org.br/estudos/estudos-itb/itb/ranking-do-saneamento-2020>

[13] Acesso em 16 jun. 2020.

[14] IZQUIERDO, G. E. ZABALETA, A.P. PÉREZ, L.V.V. (2014). "Modelización de consumos de agua y energía en hoteles de sol y playa". PASSOS, v. 12, n.4, pp.807 - 818.

[15] KLONTZA, E.E. KAMPRAGKOU, E. VERVERIDIS, K. PAPADOPOULOU, M.P. LEKKAS, D.F. (2016). "Evaluation of Water Saving Measures For Mid-Sized Tourist Lodging Units: The Case of Samos Island, Greece”. European Journal of Environmental Sciences, v. 6, n.1, pp. $37-42$.

[16] KUUDER, C. W.; BAGSON, E.; PREMPEH, V. M.; MUMUNI, A.; ADONGO, R.; AMOAKO, E. “E. Energy, water and waste management in the accommodation sector of Tamale Metropolis, Ghana". (2013). American Journal of Tourism Management, 2 (1A), pp. 1-9.

[17] LAMAS, S.; LIMA, C.; PUGA M. (2016). “Gestão Ambiental em Hotéis de Nova Friburgo/RJ: Conhecimento e Atuação de Gestores Hoteleiros Locais" in Anais do 5o Simpósio de Gestão Ambiental e Biodiversidade, Rio de Janeiro, Jun.2016, pp. 1 - 10.

[18] LÓPEZ, T.J.R. VERDECIA, D. L. DÍAZ, O.A. G. CORREA, E.M. (2015). “Uso de ósmosis inversa en el hotel Breezes Jibacoa para la desalación de agua de consumo.” Ingeniería Hidráulica Y Ambiental, v.36, n. 3, pp. 112 - 125.

[19] MEADE, B., GONZÁLEZ-MOREL, P. (1999). “Improving water use efficiency in Jamaican hotels and resorts through the implementation of environmental manage-ment systems."

http://www.linkbc.ca/torc/downs1/jaimaca\%20water.pdf. Last accessed June 2011. 
[20] NASCIMENTO, E; SANTANA D. (2014). “Caracterização dos usos-finais do consumo de água em edificações do Setor Hoteleiro de Brasília" in Anais do 3o Seminário Nacional de Construções Sustentáveis - IMED, Passo Fundo, Nov.2014, pp. $73-86$.

[21] RAHMAN, H.A.A. AL-FARSI, H. A. AL-FARSI. AHMED, M. GOOSEN, M. F. A. (2016)." Evolution of some water saving devices in urban areas: A case study from the Sultanate of Oman". Journal of Agricultural and Marine Sciences, v.22, n.1, pp.18 - 26.

[22] SCHENINI, P.; LEMOS, R.; SILVA, F. (2005). "Sistema de Gestão Ambiental Segmento Hoteleiro". Revista Eletrônica Intr@ciência,5.ed, pp.1-18.

[23] SILVA, G. M. B.; SILVA, F. A.; COSTA, D. A.; FURTADO, G. D.; VALENCIA, C. A. I. "Estudo comparativo do reuso de água na rede hoteleira de João Pessoa-PB: Uma questão de responsabilidade e sustentabilidade". Educação Ambiental em Ação, v. 65, 2018.

[24] SOARES, A. M. M. “Análise dos Consumos de Água em Edifícios Não Habitacionais”. Porto, 2010.108f. Dissertação submetida para satisfação parcial dos requisitos do grau de Mestre em Engenharia Civil — Especialização em Construções Civis. Universidade do Porto, Porto, 2010. 


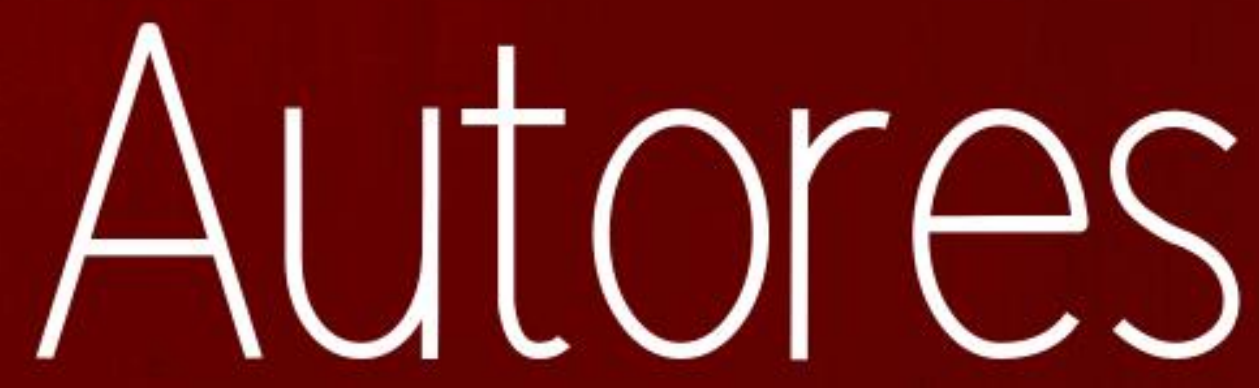




\section{JOSÉ HENRIQUE PORTO SILVEIRA (ORGANIZADOR)}

Bacharel e licenciado em Psicologia pela UFMG, Especialização em Percepção e Planejamento Urbano. Mestre em Gestão e Auditoria Ambiental, especialização em educação ambiental. Consultor em percepção e educação ambiental. Sócio diretor da Alternativa Educação e Manejo Ambiental.

\section{ADRIELE BARRELIN DE SOUZA}

Graduanda no curso Ciências Biológicas- modalidade Licenciatura no Instituto Federal de Educação, Ciência e Tecnologia do Sul de Minas Gerais- campus Muzambinho. Atuou como estagiária voluntária no Centro de Controle de Zoonoses no município de Caconde (abr/ 2019- maio/ 2019). Técnica em Farmácia pelo Centro Estadual de Educação Tecnológica Paula Souza- Campus Mococa (2015). Atualmente é membro do Grupo de Estudos de animais selvagens (GEAS) e faz parte da Coordenação de Ensino, Pesquisa e Extensão do Centro Acadêmico Vital Brazil. Áreas de interesse: Microbiologia, Zoologia e Parasitologia.

\section{ALLAN ELIAS DA SILVA}

Atualmente sou Mestrando Acadêmico na Faculdade de Ciência e Tecnologia - FCT UNESP Campus de Presidente Prudente, no Curso de Geografia, com linha de pesquisa voltada a Análise e Gestão Ambiental na área de Gerenciamento de Resíduos Sólidos. Possuo MBA - Pós-Graduação em nível Lato Sensu na Universidade do Oeste Paulista (UNOESTE) na área de Finanças e Controladoria. Sou Especialista em Gestão Pública pela UFMS - Universidade Federal do Mato Grosso do Sul. Licenciado em Formação Pedagógica (R2) em Matemática pela Universidade de Franca - UNIFRAN. Trabalhei como professor em nível EAD no curso de Administração da Universidade do Oeste Paulista na construção de Aulas-Web e Vídeo-Aulas na disciplina de Gestão e Finanças Públicas. Possuo Graduação em Administração pela União das Instituições do Estado de São Paulo - FAPE (2013) e Ciências Contábeis pela Universidade de Franca/SP (2018). Atualmente sou graduando em Bacharelado em Engenharia de Produção pela Universidade Virtual do Estado de São Paulo UNIVESP e Tecnólogo em Gestão Ambiental pela Universidade de Franca - UNIFRAN. Tenho experiência na área de Administração e docência em disciplina de cursos FIC (Formação Inicial e Continuada) no PRONATEC Campo: cursos de Agricultura Familiar e Agroflorestal, ministrando disciplinas de Associativismo, Cooperativismo e Políticas Públicas. Já fui Gestor da Política de Investimentos - DPIN do Instituto de Previdência de Caiuá/SP. Possuo Certificação ANBIMA Associação Brasileira das Entidades dos Mercados Financeiro e de Capitais, na modalidade de CPA10. Atualmente exerço a função estatutária de Contador Público na Prefeitura Municipal de Iepê/SP.

\section{ANA CAROLINE VITOR AVELAR}

Graduanda em Ciências Biológicas pelo Instituto Federal de Educação, Ciência e Tecnologia do Sul de Minas Gerais - Campus Muzambinho. Atuou como bolsista no Laboratório de Microscopia do IFSULDEMINAS - Muzambinho. Possui experiência em Ornitologia.

\section{ANA ELISABETH CAVALCANTI SANTA RITA}

Possui graduação em Medicina pela Universidade Estadual de Ciências da Saúde de Alagoas (1998). Membro Efetivo da Sociedade Brasileira de Nefrologia e Membro Efetivo da Sociedade Internacional de Nefrologia. Professora Titular da Cadeira de Nefrologia na Universidade Federal do Vale do São Francisco (UNIVASF, Campus Paulo Afonso-BA), atua na Liga Estudantil de Nefrologia e Urologia da UNIVASF, Campus Paulo Afonso-BA. Membro Titular do Núcleo Docente Estruturante da UNIVASF, Campus Paulo Afonso-BA. Membro da Comissão de Internato da UNIVASF, Campus Paulo AfonsoBA. Membro do Comitê de Políticas de Estágios na UNIVASF. Membro da Sociedade Brasileira de Plantas Medicinais. Mestra em Extensão Rural Com Ênfase na Linha de Pesquisa: Identidade, Cultura e Processos Sociais pela Universidade Federal do Vale do São Francisco. Doutoranda em Agroecologia e Desenvolvimento Territorial Com Ênfase na Linha de Pesquisa: Ambiente, Saúde e Sistemas Agroalimentares pela Universidade Federal do Vale do São francisco. Especialista em 
Preceptoria de Residência Médica no SUS pelo Hospital Sírio-Libanês.É Médica Clínica Geral e Nefrologista da Prefeitura Municipal de Paulo Afonso-BA. Tem experiência na área de Clínica Médica, Medicina de Saúde da Família, com ênfase em Nefrologia e Extensão Rural.

\section{ANNA JULIA RENZO AGUAYO}

Geógrafa, graduada pela Pontifícia Universidade Católica de São Paulo. Especializou-se em Gestão e Tecnologias Ambientais no Programa de Educação Continuada da Escola Politécnica da USP PECE/POLI. Possui experiência em elaboração de programas e projetos socioambientais com ênfase no setor portuário e logístico, atuando com licenciamento ambiental, criação de banco de dados de informações geo-espaciais, produção e edição de mapas, elaboração de diagnósticos e estudos de monitoramento ambiental e processos participativos, desenvolvendo seu trabalho tanto no setor privado como no terceiro setor. Atualmente é analista ambiental e cursa Tecnologia em Gestão Portuária, na Fatec Santos. Fala e redige com fluência em Espanhol.

\section{BRUNA LOGATTI}

Formada em Engenharia Civil (2017), em Engenharia de Computação (2020) e em Engenharia de Segurança do Trabalho (2018) pelas Faculdades Integradas de Araraquara, foi monitora das matérias de fenômenos de transporte I e II (2015) e atualmente ministra aulas sobre essa mesma disciplina. É mestre pela Universidade Federal de São Carlos - UFSCAR (2019) em Engenharia Urbana (PPGEU), sua pesquisa foi desenvolvida na área de modelagem computacional de sistemas de saneamento.

\section{CAMILA GOMES MELO}

Mestranda em Tecnologia Nuclear pelo Instituto de Pesquisas Energéticas e Nucleares (IPEN/USP) na área de aplicações, com linha de pesquisa em radiação ionizante aplicada em efluente têxtil. Graduação em Engenharia Civil pela Universidade Nove de Julho (2016) e formação Técnica Têxtil pela Escola Senai Francisco Matarazzo (2009).

\section{CARLOS HENRIQUE BRANDÃO GOMES}

Advogado regularmente inscrito na OAB/BA sob o no 44.165, possui graduação em DIREITO pela Faculdade Sete de Setembro, atual Centro Universitário do Rio São Francisco - UNIRIOS, da Cidade de Paulo Afonso-BA. Especialista em Direito Médico pelo Centro Universitário de Araraquara UNIARA. Mestrando em Extensão Rural pela Universidade Federal do Vale do São Francisco UNIVASF (Linha de pesquisa: Inovação, Processos de Inovação Sócio-Tecnológicas e Ação Extensionista). Professor do Curso de Bacharelado em Direito do Centro Universitário do Rio São Francisco - UNIRIOS, em Paulo Afonso-BA. Coordenador do Núcleo de Prática Jurídica Rui Barbosa, vinculado ao Curso de Bacharelado em Direito do Centro Universitário do Rio São Francisco, UNIRIOS, em Paulo Afonso-BA.

\section{DANIELA FERREIRA CARDOSO}

Doutoranda em Educação (UNICAMP). Mestre em Tecnologia Ambiental (UNAERP). Licenciada em Ciências Biológicas (UNIFEG). É professora efetiva do IFSULDEMINAS - campus Muzambinho e orientadora do Programa de Residência Pedagógica/CAPES. Área de atuação e pesquisa: educação, formação de professores, direitos humanos e meio ambiente.

\section{DAVID FERNANDES LIMA}

Possui graduação em Farmácia pela Universidade Federal do Ceará (1999). Doutorado em Biotecnologia pela Rede Nordeste de Biotecnologia RENORBIO - Universidade Federal do Piauí (2016). Mestrado em Farmacologia pela Universidade Federal do Piauí (2011). Especialização Lato Sensu em Plantas Medicinais pela Universidade Federal de Lavras - UFLA (2008). Atualmente é Professor Adjunto de Farmacologia da Universidade Federal do Vale do São Francisco do Colegiado 
Acadêmico de Medicina do Campus de Paulo Afonso - BA (CMED-PAV), Docente permanente do Programa de Pós-Graduação em Biociências UNIVASF - Campus Petrolina na Área de Farmacologia da Dor e Inflamação, Docente permanente do Doutorado Profissional em Agroecologia e Desenvolvimento Territorial UNIVASF- Campus Petrolina, Coordenador do Núcleo de Extensão Paulo Freire da UNIVASF - Campus Paulo Afonso, Coordenador da Liga Acadêmica de Medicamentos (LAME) CMED-PAV. Desenvolve Projetos de Extensão em Práticas Integrativas e Complementares: Plantas Medicinais e Fitoterapia. Desenvolve pesquisas relacionadas ao Uso Correto e Racional de Medicamentos. Tem experiência de 11 anos na Indústria Farmoquímica Anidro do Brasil Extrações SA nas áreas de Controle e Garantia da Qualidade e Cromatografia Líquida de Alta Eficiência, além de Parceria Público-Privada no desenvolvimento de pesquisas e patentes.

\section{DIOGO HENRIQUE FERNANDES DA PAZ}

Professor do Instituto Federal de Educação, Ciência e Tecnologia de Pernambuco - IFPE, Campus Cabo de Santo Agostinho. Doutor em Engenharia Civil (Tecnologia Ambiental) na Universidade Federal de Pernambuco (UFPE). Pesquisador - Líder do grupo de pesquisa Ambisoft - Tecnologia e Gestão Ambiental.

\section{ERICH KELLNER}

Graduado em Engenharia Civil pela Universidade Federal de São Carlos (1993), mestre em Engenharia Hidráulica e Saneamento pela Universidade de São Paulo (1996) e doutor em Engenharia Hidráulica e Saneamento pela Universidade de São Paulo (2000). Atualmente é professor associado da Universidade Federal de São Carlos, Departamento de Engenharia Civil: Área de Saneamento. Tem experiência na área de Engenharia Sanitária, com ênfase em Técnicas Convencionais de Tratamento de Águas, atuando principalmente nos seguintes temas: lagoa de estabilização, tratamento de esgoto, modelo matemático, estratificação térmica e qualidade da água.

\section{EVANY ADRIANE MARIA DIAS BATISTA}

Graduanda em Engenharia Ambiental e Sanitária no Instituto Federal de Educação, Ciência e Tecnologia de Pernambuco - IFPE, Campus Cabo de Santo Agostinho. Técnica em Saneamento Ambiental no Instituto Federal de Educação, Ciência e Tecnologia de Pernambuco - IFPE, Campus Recife. Pesquisadora do grupo de pesquisa Ambisoft - Tecnologia e Gestão Ambiental.

\section{EVELINE LEAL DA SILVA}

Professora do Curso Técnico em Edificações do IFPI - Campus Floriano. Possui Bacharelado em Engenharia Civil pela Universidade Federal do Piauí. Especialista em "Avaliações e Perícias em obras de Engenharia" pela Faculdade Oswaldo Cruz - SP, "Saúde e Segurança do Trabalho" pela Faculdade Alfa América e Mestrado em Recursos Hídricos pela Universidade Federal do Sergipe (UFS).

\section{EWERTON SANTOS}

Graduado no curso de licenciatura em Química pelo Instituto Federal de Educação, Ciência e Tecnologia do Estado de Sergipe, mestrado e doutorado em química pelo programa de pósgraduação em química da Universidade Federal de Sergipe. Realizou período de sanduíche na Brown University, Rhode Island - EUA. Atualmente, está atuando como Research Associate no departamento de Earth, Environmental, and Planetary Sciences da Universidade Brown (EUA) e Pesquisador associado na BRIDGE - Rede de Excelência em Ciência e Tecnologia do Estado de Sergipe. Tem experiência na área de Química Analítica e Química Ambiental, possuindo conhecimento na utilização da técnica de Cromatografia Gasosa, Espectrometria de Massas, Cromatografia com Detector de Ionização por Chama (FID), espectrometria de massas com razão isotópica, técnicas de preparo de amostra e análise de dados por técnicas estatísticas. 


\section{FABIOLA MANGABEIRA CEOLATO DA SILVA}

Graduanda em Ciências Biológicas pelo Instituto Federal de Educação, Ciência e Tecnologia do Sul de Minas Gerais - Campus Muzambinho. Possui experiências em educação e avaliação da aprendizagem. Atuou como estagiária no setor educacional da prefeitura de Guaxupé-MG.

\section{FERNANDO PETERSEN CARDOSO}

Graduado em Engenharia Hídrica (UFRGS). Pós-graduado em Engenharia de Segurança do Trabalho. Diretor e Responsável Técnico da Hydrosolv Engenharia e Recursos Hídricos Ltda. Tem experiência na área ambiental com ênfase em recursos hídricos; estudos de modelagem numérica em hidrologia e hidráulica; estudos de inundação para empreendimentos; zoneamento de áreas inundáveis; e; avaliação hídrica potencial superficial para empreendimentos em geral.

\section{FLÁVIA CRISTIANE FARINA}

Doutorado em Geociências (UFRGS) e Mestrado em Geografia (UFRGS). Professora Associada da Universidade Federal do Rio Grande do Sul (UFRGS). Tem experiência no ensino, pesquisa e extensão em Sensoriamento Remoto e Geotecnologias, com ênfase na área ambiental e em estudos urbanos.

\section{INAJÁ FRANCISCO DE SOUSA}

Possui graduação em Meteorologia pela Universidade Federal da Paraíba (1987), mestrado em Meteorologia pela Universidade Federal da Paraíba (1991), doutorado em Recursos Naturais pela Universidade Federal de Campina Grande (2005) e Pós-doutorado em modelagem hidrológica realizado no Instituto de Agricultura Sostenible - IAS/CISC realizado em Córdoba-Espanha (2014). Atualmente é professor associado da Universidade Federal de Sergipe, lotado no Departamento de Engenharia Agronômica. Coordenador do Programa de Pós-Graduação em Recursos Hídricos PRORH. Atua como Orientador nos Programas de Pós-graduação em Desenvolvimento e Meio Ambiente - PRODEMA e PRORH. Tem experiência na área de Agronomia, com ênfase em Agrometeorologia, atuando principalmente nos seguintes temas: modelagem hidrológica em bacia hidrográfica, necessidades hídricas de culturas e modelagem de agricultura irrigada.

\section{JHONATA WESLEY GOMES BARBOSA}

Graduando em Engenharia Ambiental e Sanitária no Instituto Federal de Educação, Ciência e Tecnologia de Pernambuco - IFPE, Campus Cabo de Santo Agostinho. Técnico em Eletromecânica pela Escola Técnica Senai - Santo Amaro. Pesquisador do grupo de pesquisa Ambisoft - Tecnologia e Gestão Ambiental.

\section{JÔ VINÍCIUS BARROZO CHAVES}

Atualmente cursando doutorado no Programa de Pós-Graduação (PPG) em Ciências Ambientais pelo Instituto de Ciência e Tecnologia da Universidade Estadual Paulista Júlio de Mesquita Filho, com metrado no PPG de Sistemas de Infraestrutura Urbana na linha de pesquisa de Planejamento Integrado e Gestão de Sistemas de Infraestrutura Urbana pela Pontifícia Universidade Católica (2021), graduado em Engenheiro Ambiental e Sanitária pela Pontifícia Universidade Católica de Campinas (2018). Experiência profissional e de pesquisa como estagiário na Empresa de Pesquisa Agropecuária (Embrapa) na unidade de Informática Agropecuária.

\section{JORGE MARCOS ROSA}

Possui graduação em Química pelo CUFSA (2001), mestrado em Engenharia de Produção pela UNINOVE (2010), doutorado em Engenharia Química pela UNICAMP (2013), pós-doutorado em Engenharia Química pela UNICAMP (2015), pós-doutorado em Engenharia de Processos Têxteis pela USP (2017) e pós-doutorado em Tecnologia de Radiações Nucleares pelo IPEN/CNEN (2020). 


\section{KARINA MARA LABANCA}

Técnica em Alimentos pelo Instituto Federal de Educação, Ciência e Tecnologia do Sul de Minas Campus Muzambinho (2016) e atualmente é graduanda em Ciências Biológicas (Licenciatura), pela mesma instituição. Participa como bolsista CAPES no Programa Residência Pedagógica (20202021). Atua na linha de pesquisa de análises dos conteúdos de livros didáticos adotados no Ensino Médio.

\section{LETÍCIA HELEN DE REZENDE}

Graduada em Engenharia Civil pela Pontifícia Universidade Católica de Minas gerais, possui experiência nos segmentos de mineração e consultoria, atuante em projetos de gestão de processos e gestão de pessoas. Possui formação extracurricular complementar em empreendedorismo pela Babson College (Boston) e em transformação digital pelo Massachusetts Institute of Technology (Boston). Profissional certificada nas metodologias PMD Pro (Gestão de Projetos de Desenvolvimento) e SFC (Scrum Fundamentals Certified). Atualmente é Business Analyst em uma das maiores consultorias de gestão do país.

\section{LIA TOLEDO MOREIRA MOTA}

Engenheira Eletricista formada pela Universidade Estadual de Campinas (1998), com mestrado em Engenharia Elétrica (2001). Doutora em Engenharia Elétrica (2005) e Pós-doutorado em Engenharia Elétrica pela Universidade Estadual de Campinas (2006); em Engenharia Elétrica pela McGill University (2006-2007), Montreal, Canadá; e em Eficiência Energética pela Universidade Estadual de Campinas (2010). É Professora Doutora, em Regime de Dedicação (40h), da Pontifícia Universidade Católica de Campinas; Docente permanente do PPG em Engenharia Elétrica da PUCCampinas; Docente permanente do PPG em Sistemas de Infraestrutura Urbana da PUC-Campinas; Coordenadora do PPG em Engenharia Elétrica da PUC-Campinas;

\section{LUCIANE TASCA}

Graduada em Arquitetura e Urbanismo pela UFJF (1999), Especialista em Planejamento e Uso do Solo Urbano pelo IPPUR/UFRJ (1999), Mestre em Planejamento Urbano e Regional pelo IPPUR/UFRJ (2002) e Doutora em Planejamento Urbano e Regional pelo IPPUR/UFRJ (2010). Professora Associada da Faculdade de Arquitetura e Urbanismo da Universidade Federal de Juiz de Fora. Líder do Laboratório da Paisagem _ LAPASA/ FAU/ UFJF. Presidente do Conselho Municipal de Política Urbana de Juiz de Fora. Áreas de Concentração: Projetos Urbanos, Projeto de Arquitetura e Urbanismo, Estudos Urbanos, Sociais e da Paisagem, Planejamento Urbano e Regional, Legislação Urbana e Políticas Públicas, Metodologia de Pesquisa, Geografia da Religião, Pesquisa e Extensão Universitárias.

\section{LUIZ FERNANDO FERREIRA}

Graduando em Ciências Biológicas pelo Instituto Federal de Educação, Ciência e Tecnologia do Sul de Minas - Campus Muzambinho, onde atuou como monitor de Zoologia de Invertebrados II e Ecologia; estagiário voluntário do Laboratório de Zoologia; e bolsista de Iniciação Científica (PIBIC/CNPq). Atualmente é bolsista do Programa de Residência Pedagógica (CAPES) no IFSULDEMINAS; membro do grupo de estudos GPlant in vitro; aluno especial (não regular) do Programa de Pós-Graduação em Ciências Ambientais na Universidade Federal de Alfenas (PPGCA/UNIFAL); e membro da Liga Acadêmica de Ilustração Científica da Universidade Federal do Vale do São Francisco (LAIC/UNIVASF).

\section{MARCELA SOARES SOUZA VAZ CORREIA}

Graduada em Engenharia Civil pela Pontifícia Universidade Católica de Minas Gerais - PUC Minas. Experiência como estagiária na elaboração de projetos de engenharia sanitária tais como sistema de abastecimento de agua, sistema de esgotamento sanitário, drenagem pluvial e em orçamentos com base na planilha COPASA - companhia de saneamento de Minas Gerais. Atualmente é Auxiliar de 
Engenharia atuando no setor de projetos, no estudo de concepções, desenvolvimento e orçamento dos mesmos.

\section{MARCELO DA ROSA ALEXANDRE}

Possui graduação em Licenciatura e Bacharelado em Química pela Universidade Federal de Santa Catarina (1999) e doutorado em Química também pela Universidade Federal de Santa Catarina (2006). Trabalhou como pesquisador técnico (2005-2008) e professor visitante (2017-2018) na Brown University - USA. Tem experiência na área de Química Analítica, Química Ambiental e Oceanografia Química. Possui vasto conhecimento em cromatografia gasosa acoplada com espectrometria de massa, FID, ECD, TCD bem como IRMS e Análise Elementar. Nos últimos anos, tem atuado principalmente nas áreas de química analítica, biomarcadores, análise de isótopos estáveis, poluentes orgânicos entre outros relacionados à química ambiental e oceanografia química.

\section{MÁRCIA BENTO MOREIRA}

Graduada (1995) em Medicina Veterinária pela Universidade de Marília; Mestre (2001) em Técnicas Operatórias e Cirurgia Experimental pela Universidade Federal de São Paulo - Escola Paulista de Medicina (UNIFESP - EPM); Doutora (2006) em Cirurgia e Experimentação pela UNIFESP - EPM. Em 2011 recebeu o título de médica veterinária hiperbarista pela Sociedade Brasileira de Medicina Hiperbárica. Na Universidade Federal do Vale do São Francisco - UNIVASF - possui as seguintes funções e cargos: Professora Adjunta III, ministra aulas na Graduação (curso de Medicina Veterinária - http://www.veterinaria.univasf.edu.br/?pg=paginasrelacaodosdocentes-html) e na PósGraduação [Ciências da Saúde e Biológicas (http://www.ppgcsb.univasf.edu.br/); Extensão Rural (http://www.pgextensaorural.univasf.edu.br/) e no de Agroecologia e Desenvolvimento Territorial (http://ppgadt.univasf.edu.br/)]; foi nomeada em junho de 2019 presidente do Fórum de Coordenadores de Programas de Pós-Graduação Interdisciplinares do Brasil (http://www.inpe.br/datalab/ForumPPGI/gestor.jsp); Coordena a Liga Acadêmica em Anestesiologia Veterinária, Dor e Terapia Intensiva - Mandrágora desde 2018.2; é Membro do Centro de Recondicionamento de Computadores vinculado ao Ministério de Ciência, Tecnologia, Inovação e Comunicações (http://crc.univasf.edu.br/; Membro do curso de Especialização em Educação no e do Campo/PRONERA; Coordena o Programa de Pós-Graduação em Agroecologia e Desenvolvimento Territorial - PPGADT da Univasf, Interdisciplinar, nível Doutorado Profissional. Coordenou o Mestrado Profissional em Extensão Rural, interdisciplinar, de 2016 até 2018; Concebeu e criou o Programa de Pós-Graduação Ciências da Saúde e Biológicas - PPGCSB, Interdisciplinar, nível Mestrado Acadêmico durante o interstício de 2010 a 2012; Implantou e Coordenou o PPGCSB durante o período de 2012 a 2015; Foi Presidente Adjunta do Comitê de Ética e Deontologia em Estudos e Pesquisa desde 2011 à 2015; Coordenou a Comissão de Ética no Uso

\section{MARIA DA CONCEIÇÃO COSTA PEREIRA}

Possui graduação em Química Industrial pela Escola Superior de Química Oswaldo Cruz (1984), Mestrado pelo Instituto de Pesquisas Energéticas e Nucleares - USP (1997) e doutorado pelo Instituto de Pesquisas Energéticas e Nucleares - USP (2006). Atualmente é pesquisadora do Instituto de Pesquisas Energéticas e Nucleares e orientadora de Mestrado.

\section{MICHEL RUBENS DOS REIS SOUZA}

Pós-Doutorado em andamento no Programa de Biotecnologia Industrial, Universidade Tiradentes PBI/UNIT. Doutor em Química pela Universidade Federal de Sergipe (2019) com período sanduíche na Brown University, Rhode Island - EUA. Mestrado em Química pela Universidade Federal de Sergipe (2012). Graduação em Química Bacharelado pela Universidade Federal de Sergipe (2010). Formação Técnica em Análises e Processos Químicos no Instituto Federal de Educação, Cência e Tecnologia de Sergipe - IFS (2005). Foi professor da Universidade Federal de Sergipe entre 2014 e 2016, lotado no Departamento de Química. Atua principalmente nos seguintes temas: novas metodologias analíticas, validação de metodologias analíticas, marcadores geoquímicos orgânicos, química analítica ambiental, produtos naturais, métodos de extração e cromatografia em fase gasosa acoplada à espectrometria de massas. 


\section{MICHELLE PEREIRA DA COSTA SILVA}

Mestre e Doutoranda em Geografia pela Universidade Federal de Sergipe (UFS), licenciada em Geografia pela Universidade Estadual de Feira de Santana (UEFS). Atuou como Tutora Presencial da Universidade Aberta do Brasil na Universidade Estadual da Bahia (UNEB). Realiza estudos na linha de pesquisa da Dinâmica ambiental, com ênfase nas questões socioambientais no espaço urbano para os seguintes temas: bacias hidrográficas, recursos hídricos, clima urbano, derivações antropogênicas e Sistemas de Informação Geográfica.

\section{NÍVIA RAQUEL OLIVEIRA ALENCAR}

Tecnóloga em Saneamento Ambiental pelo Instituto Centro de Ensino Tecnológico CENTEC CARIRI - FATEC, Juazeiro do Norte-CE. Especialista em "Educação Ambiental e Desenvolvimento Sustentável" pela Faculdade de Juazeiro do Norte (FJN), Juazeiro do Norte-CE. Mestre em Recursos Hídricos pela Universidade Federal de Sergipe (UFS). Experiência em qualidade de água com enfoque em reservatórios de água superficial em região semiárida, tratamento e monitoramento de águas de circulação industrial, estação de tratamento de efluentes (ETE), estação de tratamento de água (ETA), gestão de resíduos sólidos e educação ambiental. Atualmente (2021) cursando doutorado acadêmico em Desenvolvimento e Meio Ambiente pela Universidade Estadual de Santa Cruz.

\section{PEDRO HENRIQUE FERNANDES LAGE}

Técnico em Estradas pelo Centro Federal de Educação Tecnológica de Minas Gerais - CEFET-MG e graduado em Engenharia Civil pela Pontifícia Universidade Católica de Minas Gerais - PUC Minas. Experiência como estagiário de produção na elaboração de relatórios de custos, além de estagiar em laboratório de análise de solos. Trabalhou como auxiliar e assistente no setor de projetos e gerenciamento de obras de Engenharia Civil. Atualmente é Analista de Engenharia atuando no setor de medição, verificando e analisando contratos, dados de controle tecnológico de serviços executados, saldos e prazos contratuais.

\section{RAMIRO FERREIRA DOS SANTOS FARIAS}

Possui graduação em Tecnologia em Saneamento Ambiental pelo Instituto Federal de Sergipe (2009), graduação em Engenharia Ambiental pela Universidade Tiradentes (2017) e mestrado em Recursos Hídricos pela Universidade Federal de Sergipe (2020). Foi Analista Ambiental, trabalhando como coordenador de equipe para a empresa ICF Consultoria do Brasil, que atuava em serviços de consultoria ambiental para a PETROBRAS S.A. no Projeto de Controle da Poluição (PCP) das atividades offshore na bacia de Sergipe e Alagoas.

\section{RAQUEL ELISAMARA DA SILVA LIMA}

Graduanda no de Curso Ciências Biológicas, do Instituto Federal de Educação, Ciência e Tecnologia do Sul de Minas Gerais - Campus Muzambinho. Possui vivências na área de Educação, com ênfase em Educação Especial e Saúde mental, com ênfase em Aprendizagem Social. Além disso, possui vivência como Mediadora Virtual, com ênfase no Desenvolvimento Integral dos alunos (as) graduandos (as). Apresenta como interesse, temas sobre Educação.

\section{RAQUEL SAMPAIO JACOB}

Graduada em Ciências Biológicas pela Pontifícia Universidade Católica de Minas Gerais. Especialista em Saneamento e Meio Ambiente pela Escola de Engenharia da UFMG, na área de Controle Ambiental na Indústria. Mestre e Doutora em Saneamento, Meio Ambiente e Recursos Hídricos pela Escola de Engenharia da UFMG. É Professora Adjunto I da Pontifícia Universidade Católica de Minas Gerais, atuando ainda como Coordenadora da Pesquisa e Coordenadora adjunta do Curso de Engenharia Civil (Unidade Barreiro) dessa Universidade. Áreas de atuação: Ecotoxicologia, Gestão e Engenharia Ambiental, Engenharia Sanitária, Recursos Hídricos, além de Limnologia. 


\section{REGINA MÁRCIA LONGO}

Professora e pesquisadora em dedicação integral da Pontifícia Universidade Católica de Campinas e membro do corpo permanente de docentes dos cursos de mestrado em Sistemas de Infraestrutura Urbana (PUC-Campinas) e Sustentabilidade (PUC-Campinas). Possui graduação em Agronomia pela Universidade Estadual Paulista Júlio de Mesquita Filho (1991), mestrado em Engenharia Agrícola pela Universidade Estadual de Campinas (1994), doutorado em Engenharia Agrícola pela Universidade Estadual de Campinas (1998), pós-doutorado pela UNESP-Jaboticabal (2003) e estagio pós doutoral pela Universidade da Califórnia-Riverside (2015).

\section{SUELI IVONE BORRELY}

Possui graduação em Ciências Biológicas Licenciatura Plena pela Universidade de Santo Amaro (1984), mestrado em Tecnologia Nuclear pela Universidade de São Paulo (1995) e doutorado em Tecnologia Nuclear pela Universidade de São Paulo (2001). Atualmente é tecnologista da Comissão Nacional de Energia Nuclear.

\section{TAMIRIS DA SILVA ALVES}

Graduada em Geografia-Licenciatura (UFRGS). Graduanda em Bacharelado em Geografa (UFRGS) e Pós-graduanda em Gestão de Projetos em Tecnologia da Informação e Gestão de Projetos e Metodologias Ágeis (MBA). Tem experiência em projetos de geotecnologias aplicadas ao meio ambiente e governo.

\section{TATIANE APARECIDA PEREIRA MENDES}

Engenheira civil, graduada pela PUC-Minas. Desde então, continua os estudos se especializando em estruturas. No trabalho, atua coordenando Obras Residenciais de alto luxo. Cuida do planejamento financeiro, cronograma de execução, relacionamento com cliente e acompanhamento diário das obras.

\section{VANESSA SILVA GRANADEIRO GARCIA}

Doutora em Ciências pelo Instituto de Pesquisas Energéticas e Nucleares, Universidade de São Paulo (IPEN/USP), Mestrado pelo Instituto de Pesquisas Energéticas e Nucleares, Universidade de São Paulo (IPEN/USP), Especialização em Ciência e Tecnologia pela Universidade Federal do ABC (UFABC). Graduação em Ciências Biológicas (Licenciatura e Bacharelado) pela Universidade Presbiteriana Mackenzie (2008/2009).

\section{XIRLEY PEREIRA NUNES}

Possui Graduação em Farmácia - Habilitação I pela Universidade Federal da Paraíba (2002), Mestrado (2005) e Doutorado (2008) em Produtos Naturais e Sintéticos Bioativos (Área: FARMACOQUìMICA) pelo Programa de Pós-graduação em Produtos Naturais e Sintéticos Bioativos no Laboratório de Tecnologia Farmacêutica da UFPB. Atualmente é Professora Associada III da Universidade Federal do Vale do São Francisco-UNIVASF em Petrolina-PE, lotada no colegiado de Ciências Farmacêuticas. Na graduação ministra as disciplinas de Farmacognosia, Fitoterapia, Tópicos Especiais em Produtos Naturais, Núcleo Temático. Na pós-graduação as disciplinas de: Metabólitos Secundários do Semiárido; Políticas Públicas e Práticas de Saúde; Plantas no Tratamento da Saúde e do Ambiente. Atuou como professora formadora em alguns cursos EAD/UNIVASF. Foi coordenadora do Programa de Pós-graduação em Recursos Naturais do Semiárido (Biociências) (nível mestrado) no período de 2015-2017, e atualmente é professora permanente do programa. É professora colaboradora nos programas: RENORBIO (Rede Nordeste de Biotecnologia), nível doutorado e Agroecologia e Desenvolvimento Territorial - UNIVASF, nível doutorado. Atualmente compõe o Núcleo Docente Estruturante (NDE) do curso de Farmácia. Tem experiência na área de Farmácia, com ênfase em Farmacoquímica, atuando principalmente nos seguintes temas: Fitoquímica, Produtos Naturais, Metabólitos Secundários de Plantas do Nordeste Brasileiro. Em Fitoterapia atua nas áreas de Etnofarmacologia, Saúde Pública, Farmácia Viva. Na 
área de extensão já participou do Programa Institucional de Bolsas de Extensão (PIBEX)-UNIVASF coordenando projetos de Farmácia Viva Popular (2016) e participou do Projeto Pró-Saúde / PetSaúde / Redes (2016-2017). 
zines

axis

sर

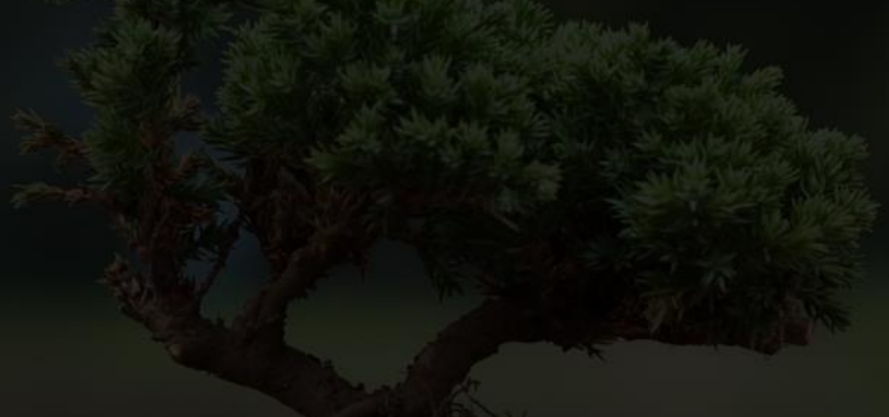

